\title{
PERSPECTIVAS DE RESPONSABILIDAD POR DAÑOS AMBIENTALES EN COLOMBIA
}

Gloria Amparo Rodríguez

Iván Vargas Chaves

-Editores académicos-

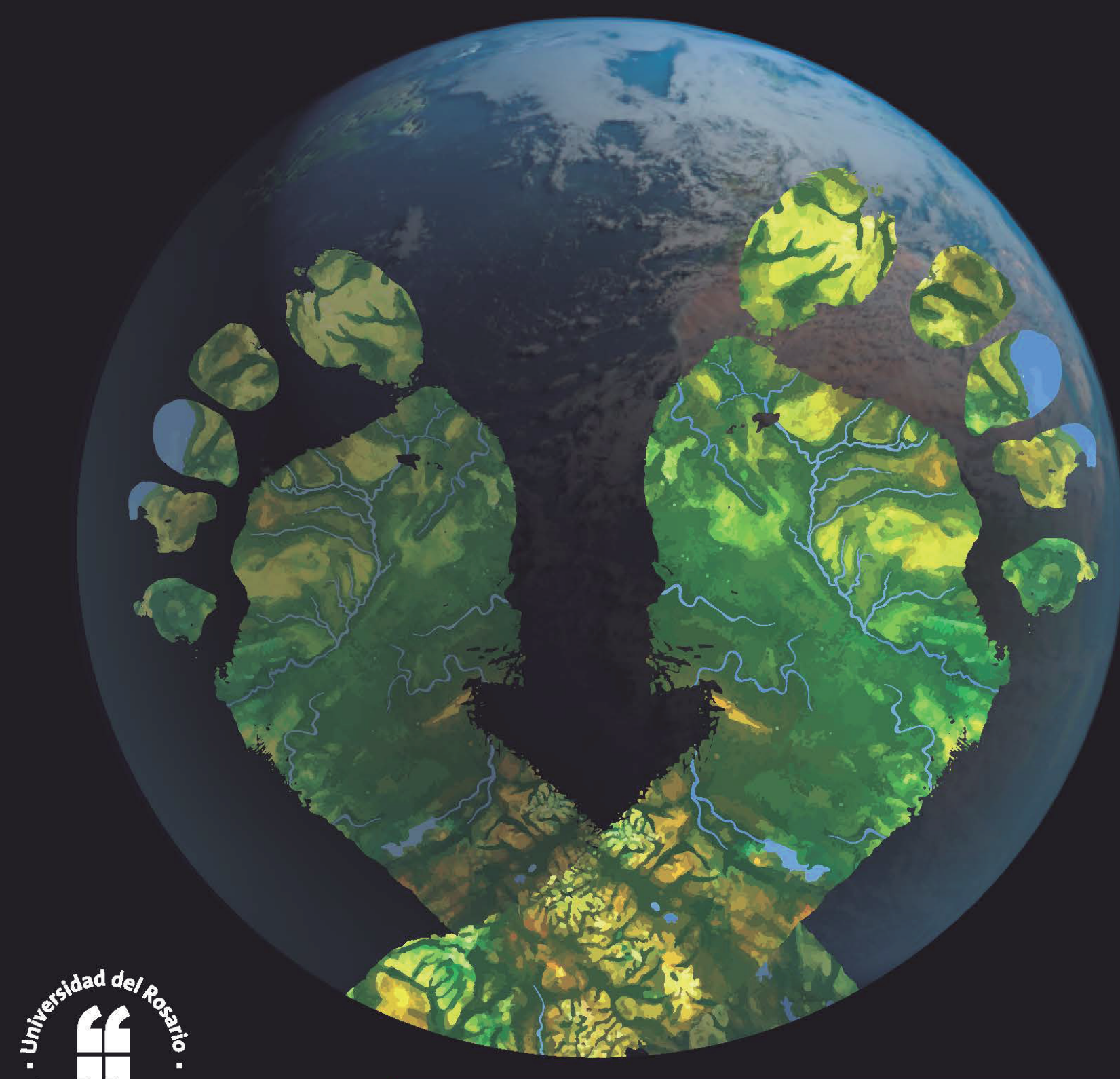

Colección Textos de Jurisprudencia 

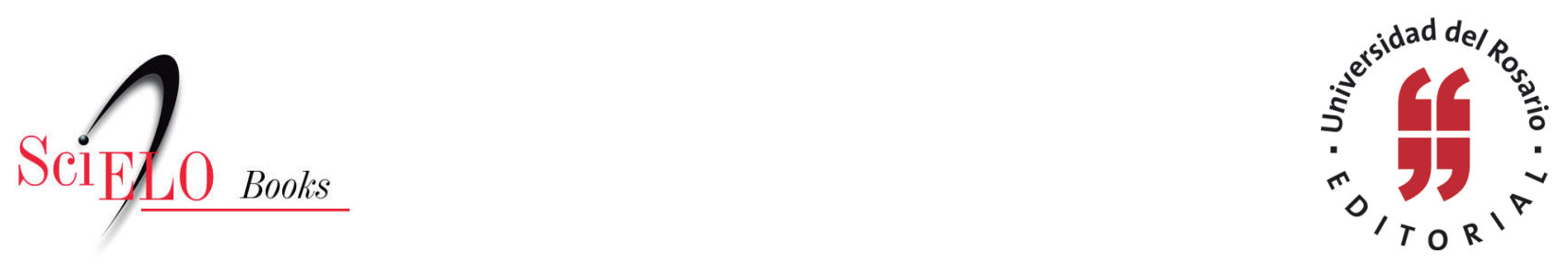

\title{
Perspectivas de responsabilidad por daños ambientales en Colombia
}

\author{
Gloria Amparo Rodríguez \\ Iván Vargas Chaves \\ (Editores académicos)
}

\section{SciELO Books / SciELO Livros / SciELO Libros}

AMPARO RODRÍGUEZ, G., and VARGAS CHAVES, I., ed. Perspectivas de responsabilidad por daños ambientales en Colombia [online]. Bogotá: Editorial Universidad del Rosario, 2015, 193 p. Textos de Jurisprudencia collection. ISBN: 978-958-738-644-8. https://doi.org/10.7476/9789587386448.

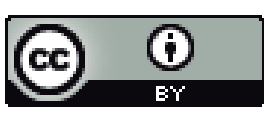

All the contents of this work, except where otherwise noted, is licensed under a Creative Commons Attribution 4.0 International license.

Todo o conteúdo deste trabalho, exceto quando houver ressalva, é publicado sob a licença Creative Commons Atribição $\underline{4.0}$.

Todo el contenido de esta obra, excepto donde se indique lo contrario, está bajo licencia de la licencia $\underline{\text { Creative }}$ Commons Reconocimento 4.0. 


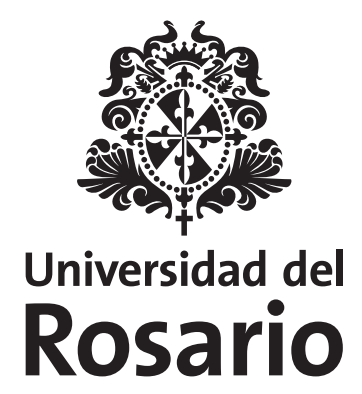





\section{Perspectivas de responsabilidad por daños ambientales en Colombia}


Rodríguez, Gloria Amparo

Perspectivas de responsabilidad por daños ambientales en Colombia / Gloria Amparo Rodríguez, Iván Vargas Chaves. - Bogotá : Editorial Universidad del Rosario, Facultad de Jurisprudencia, 2015.

x, 193 páginas. - (Colección Textos de Jurisprudencia)

Incluye referencias bibliográficas.

ISBN: 978-958-738-643-1 (impreso)

ISBN:978-958-738-644-8 (digital)

Responsabilidad por daños al medio ambiente - Colombia / Control ambiental - Legislación - Colombia / Protección del medio ambiente - Legislación - Colombia / Conservación de los recursos naturales - Legislación - Colombia / Derecho ambiental - Colombia / I. Vargas Chaves, Iván / II. Universidad del Rosario, Facultad de Jurisprudencia / III. Título / IV. Serie.

$344.046 \quad$ SCDD 20

Catalogación en la fuente - Universidad del Rosario. Biblioteca

$\mathrm{amv}$

Julio 27 de 2015

Hecho el depósito legal que marca el Decreto 460 de 1995 


\section{Perspectivas de responsabilidad por daños ambientales en Colombia}

Gloria Amparo Rodríguez Iván Vargas Chaves

-Editores académicos- 
Colección Textos de Jurisprudencia

(C) Editorial Universidad del Rosario

(C) Universidad del Rosario, Facultad de Jurisprudencia

(C) Varios autores
Primera edición: Bogotá D. C., septiembre de 2015

ISBN: 978-958-738-643-1 (impreso)

ISBN: 978-958-738-644-8 (digital)

Coordinación editorial: Editorial Universidad del Rosario Corrección de estilo: Lina Morales Diseño de cubierta: Kelly Narváez Diagramación: Martha Echeverry Impresión: Xpress. Estudio Gráfico y Digital S.A.

Impreso y hecho en Colombia Printed and made in Colombia

Fecha de evaluación: 16 de abril de 2015

Fecha de aceptación: 16 de junio de 2015

Todos los derechos reservados. Esta obra no puede ser reproducida sin el permiso previo por escrito de la Editorial Universidad del Rosario. 


\section{Contenido}

Reflexiones preliminares sobre la responsabilidad por daños

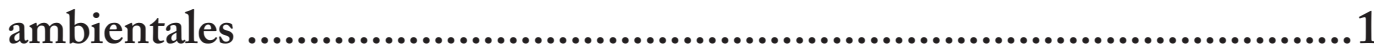

Gloria Amparo Rodriguez,

Iván Vargas Chaves

1. Aproximación al estudio del daño extrapatrimonial en la responsabilidad civil derivada del daño ambiental

Fernando Andrés Pico Zúñiga

Introducción

1.1. Breve referencia a la responsabilidad civil ambiental

1.2. El daño extrapatrimonial en el derecho del medio ambiente

1.3. La compensación del daño extrapatrimonial en el derecho del medio ambiente

Bibliografía

2. De la causalidad adecuada a la imputación objetiva en la responsabilidad civil colombiana. Aplicación particular en la responsabilidad civil ambiental

Sergio Rojas Quiñones,

Juan Diego Mojica Restrepo

2.1. El problema general de la relación de causalidad y su solución 35

2.1.1. Causalidad en materia de responsabilidad civil. Una aproximación a las diferentes teorías

2.1.2. La tesis de la causalidad adecuada 47

2.1.3. Causalidad de hecho y causalidad de derecho. Hacía una teoría de la imputación objetiva 55

2.1.4. Problemas de sobredeterminación e incertidumbre causal 
2.1.4.1. El problema de la sobredeterminación

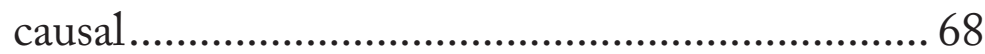

2.1.4.2. El problema de la incertidumbre causal................ 71

2.2. La aplicación de las soluciones propuestas en el escenario específico de la responsabilidad ambiental........................................... 78

2.2.1. La causalidad probable y las presunciones

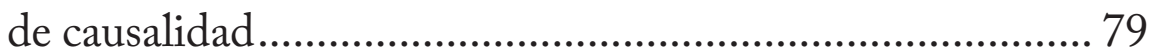

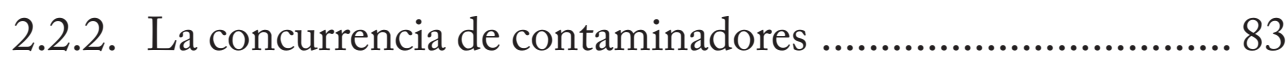

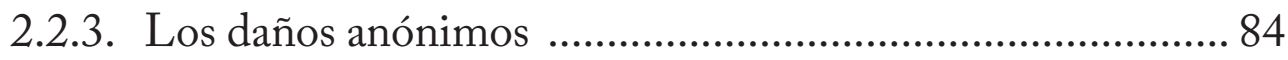

2.2.4. La labor del juez en el análisis de la causalidad .................. 85

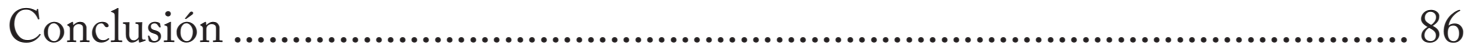

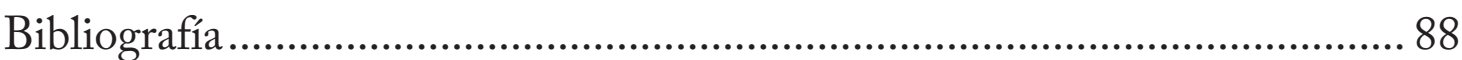

3. El daño desde la teoría de la responsabilidad ambiental ........................93

Gustavo Adolfo Ortega Guerrero,

Tito Simón Ávila Suárez

Introducción

3.1. Avances desde la jurisprudencia internacional y nacional

sobre el daño ambiental y la teoría de la responsabilidad ambiental

3.1.1. Jurisprudencia internacional comparada en materia del daño ambiental y responsabilidad

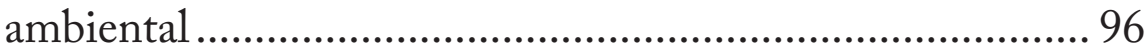

3.1.2. Jurisprudencia nacional en materia de daño ambiental

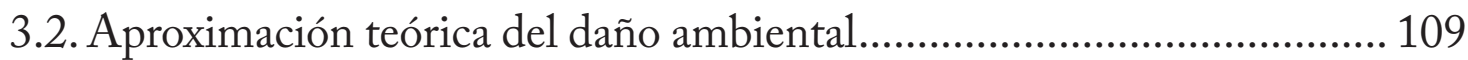

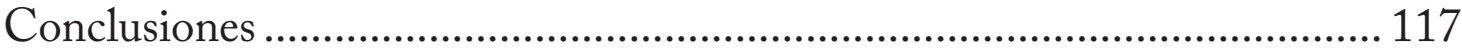

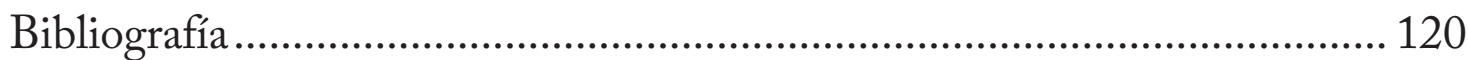

4. Daños por contaminación de hidrocarburos persistentes en el mar y su cobertura en el derecho civil colombiano.......................127 Jouline Ropero Patarroyo

Introducción

4.1. Regulación de la responsabilidad civil por daños derivados de la contaminación marina por hidrocarburos en Colombia

4.2. Daños resarcibles 
4.2.1. Daños patrimoniales ....................................................... 135

4.2.1.1. Daño emergente ............................................... 135

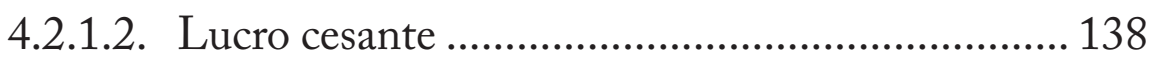

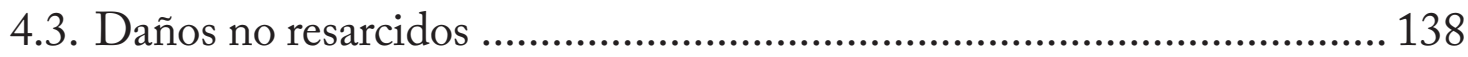

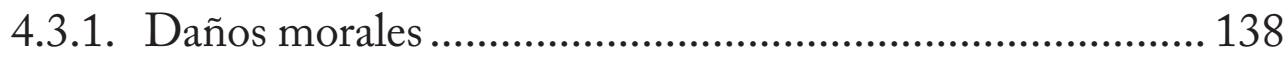

4.3.2. Daño ambiental puro ....................................................... 139

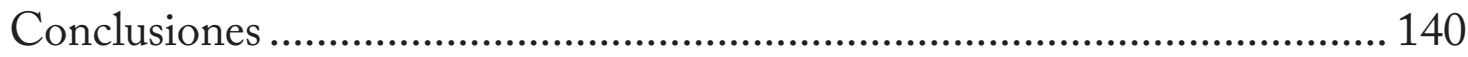

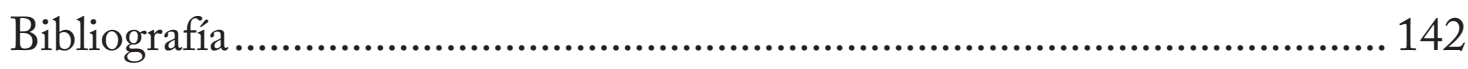

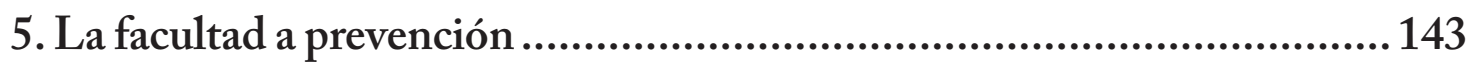

Andrés Gómez Rey,

Gloria Amparo Rodriguez,

Iván Vargas Chaves

Introducción

5.1. Parte general. Conceptos del derecho administrativo necesarios para el análisis de la facultad a prevención .......................................... 146

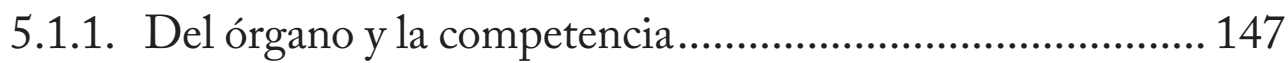

5.1.2. Del incumplimiento del órgano y la competencia............. 149

5.2. Parte especial. De la facultad a prevención.............................................. 152

5.2.1. Únicamente podrá ser utilizada por algunas de las entidades del Estado. Sujeto activo de la facultad a prevención .......................................................... 153

5.2.2. Funciones que comprenden la facultad a prevención ....................................................................... 158

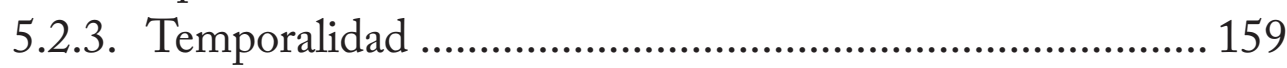

5.2.4. Sin perjuicio de las competencias legales de otras autoridades ……........................................................... 160

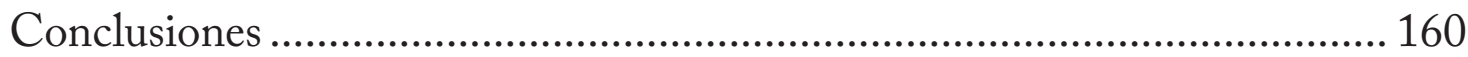

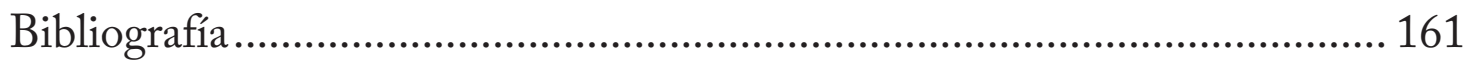

6. E1 seguro ecológico y la responsabilidad ambiental en Colombia ............ 163 JoséLópez Oliva

Introducción 163

6.1. Disposiciones constitucionales relacionadas con el medio ambiente. 
6.2. La tensión existente entre la protección del medio ambiente y la explotación económica de los recursos naturales 166

6.2.1. La Conferencia de Estocolmo y la protección del medio humano.... 167

6.2.2. Los principios que orientan la protección del medio ambiente en Colombia 168

6.2.3. Safety Management Code y el transporte marítimo de personas y mercancías

6.3. El régimen de responsabilidad ambiental aplicado en Colombia 171

6.3.1. La Revolución Industrial y el medio ambiente 171

6.4. El seguro ecológico 173

6.4.1. Objetivo de la celebración de un contrato

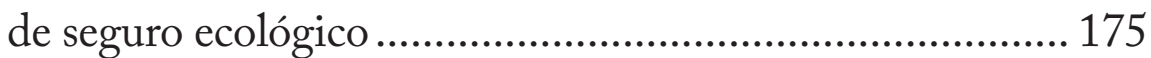

6.4.2. Características del seguro ecológico ................................... 176

6.4.3. Clases de seguro ecológico ................................................. 177

6.4.3.1. El seguro ecológico obligatorio .......................... 177

6.4.3.2. Seguro ecológico voluntario ................................. 179

6.4.4. Elementos esenciales del seguro ecológico......................... 180

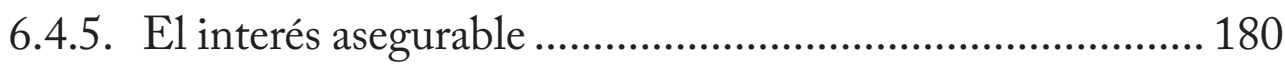

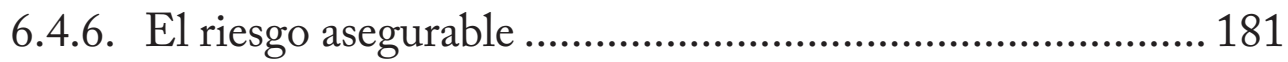

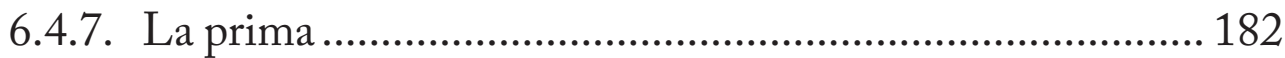

6.4.8. La obligación condicional del asegurador ........................... 183

6.5. Intervinientes en el seguro ecológico .................................................... 184

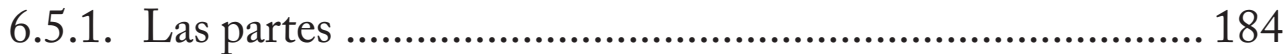

6.5.1.1. El tomador o asegurado..................................... 185

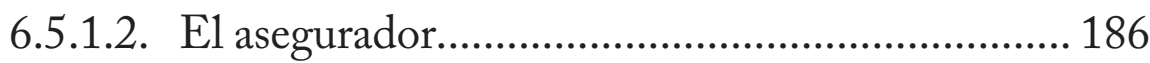

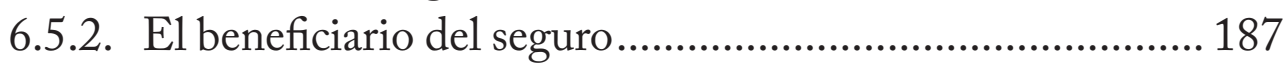

6.5.3. Los intermediarios del seguro ecológico ............................ 188

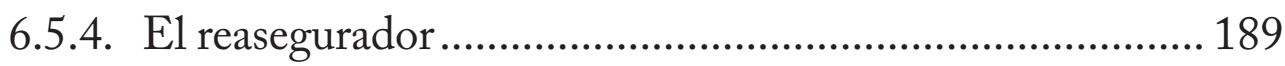

6.5.5. El sistema 'claims made' en el seguro ecológico.................. 190

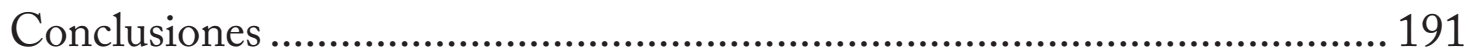

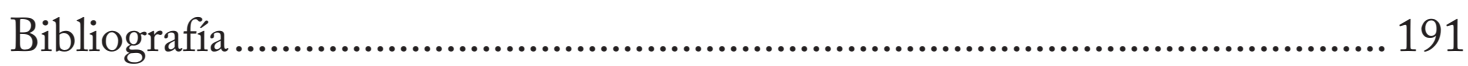




\title{
Reflexiones preliminares sobre la responsabilidad por daños ambientales
}

\author{
Gloria Amparo Rodríguez \\ Iván Vargas Chaves
}

Hoy por hoy, es un hecho que como sociedad altamente globalizada e industrializada nos encontramos ante un entorno de deterioro ambiental difícilmente reparable; consecuencia de decisiones reflejadas en políticas que han menospreciando el lugar que ocupa el hombre en un medio que no le pertenece, y en donde han imperado los sistemas de producción y las nuevas tecnologías ante la conservación del ambiente de cara a las nuevas generaciones.

Este accionar humano se encuentra revestido por el poder de modificar la naturaleza atendiendo a los intereses propios, lo cual, de acuerdo con el principio de responsabilidad de Jonas (1985, p. 179), le habrá de imponer al hombre una carga u obligación ética orientada hacia el futuro. Se trata de un postulado que ha sido interpretado por diversos teóricos, entre ellos Attfield (1991, p. 202) y De Siqueira (2001, p. 280), como un llamado sensato que clama prudencia y equilibrio en las decisiones que advienen de la desconstrucción y la aleatoria reconstrucción tecnológica de la sociedad y el ambiente.

La razón por la cual esta obligación ética debe orientarse hacia el futuro se fundamenta en nuestra consideración en dos postulados. Primero, en el principio de igualdad intergeneracional como una extensión del derecho a la igualdad, ya que el derecho a la vida, así como otros derechos dentro del catálogo de libertades y garantías fundamentales, deben ser resguardados por la actual generación, tanto para sí misma como para las futuras generaciones. Y segundo, en los beneficios y cargas ambientales dentro de la dimensión distributiva del principio de la justicia ambiental.

En efecto, la justicia ambiental como una columna sobre los cimientos de la ética ambiental responde a una distribución equitativa de estas cargas, 
con miras a soportar las oportunidades de hacer parte de la dimensión participativa en la toma de decisiones de la igualdad intergeneracional (Ayestaran, 2008 , p. 156) y es en este punto en el que nuestros gobernantes tienen una gran tarea pendiente.

Jonas (1985,pp.12-15), al reinterpretar el imperativo categórico de Kant, hace énfasis en la responsabilidad que tiene esta sociedad por ambas generaciones: la actual y la venidera, así como también para la biosfera en su conjunto. Una responsabilidad que aún no se ha asumido como es debido y que sigue llevándonos a todos los seres vivos a un escenario sombrío, amenazado por un desequilibrio ambiental que no tiene vuelta atrás.

No en vano secuelas como las alteraciones climáticas y ambientales han dado lugar a predicciones funestas sobre el desarrollo de toda la biosfera en general y a cuestionamientos sobre la supervivencia de las especies vivas en este planeta. Actualmente, incluso existe un amplio consenso por parte de la comunidad científica en relación con que el cambio climático es ya una realidad. Es el caso del Intergovernmental Panel on Climate Change, que desde 2007 viene reafirmando su postura sobre las actividades llevadas a cabo por el ser humano, las cuales seguirán alteranndo el panorama climático mundial.

Llegados aquí, el Banco Mundial y la Organización para la Cooperación y el Desarrollo Económico (oECD), entre otros organismos, plantearon, a través de un informe en la Convención Marco de las Naciones Unidas, un futuro en el que la alteración ambiental causada por el hombre: reducirá aún más el acceso al agua potable; afectará negativamente la salud de los habitantes de los países bajo el umbral de desarrollo; y se convertirá en una amenaza real para la seguridad alimentaria en muchos países de África, Asia y América Latina (Abeygunawardena et al., 2002, p. 7).

Para citar tan solo un ejemplo, en el informe sobre la economía del cambio climático en Paraguay, publicado por las Naciones Unidas a través de la Comisión Económica para América Latina y el Caribe (Cepal, 2014, p. 41), se prevén en dicho país reducciones significativas de la productividad de la agricultura familiar, con efectos sociales importantes; en el ámbito sanitario, se observaría un efecto diferenciado en patologías como dengue, malaria, enfermedades diarreicas e infecciones respiratorias agudas.

En cuanto a recursos hídricos, se afectaría la disponiblidad de agua de manera estacional, con una mayor variabilidad en las precipitaciones. Ello sin dejar a un lado los efectos de las subidas de temperatura, acompañadas de períodos 
de sequía más prolongados. Por último, destaca el referido informe que, si bien los impactos en la fauna y flora son difíciles de predecir, es claro que algunas especies podrían beneficiarse y otras extenguirse (Cepal, 2014, pp. 10-46-60).

De cualquier modo, los costes económicos y sociales de las afectaciones globales al ambiente son muy inciertos, pero quizá donde reside el mayor peligro es en el potencial de poner en riesgo el desarrollo no solo de los países pobres, sino de todos aquellos habitables por las generaciones venideras. Por ende, si bien algunos países con recursos logran mitigar los efectos globales, en un futuro a ninguno le será posible soportar ni la carga en términos de pérdida de vidas, ni los costes asociados a la devastación en el medio que traerán consigo las alteraciones ambientales.

Con todo y ello, no es necesario delinear una nueva visión del mundo, ya que el estado actual de la ciencia ha sido capaz de proveernos del real alcance de la naturaleza, como un desafortunado conjunto de objetos que el ser humano ha utilizado indiscriminadamente en las últimas décadas para satisfacer sus necesidades materiales, sin importar los efectos globales negativos, que de paso se han acelerado y que hoy en día ponen como un objeto de consideración ética la relación hombre-naturaleza.

Estamos ante lo que — para la concepción jonasiana- es fiel reflejo del divorcio entre los avances científicos y la reflexión ética, en tanto las nuevas tecnologías han introducido acciones, objetivos y consecuencias de magnitudes tan diferentes e imprevisibles que los marcos de la ética tradicional no son capaces de contener (De Siqueira, 2001, p. 281).

Adicional a lo anterior, como lo advierte Grandjean (2013, p. 627), la ciencia tampoco ha sido capaz de hacer un seguimiento adecuado a las decisiones en materia de políticas públicas, en pro del mejoramiento de las condiciones ambientales.

De acuerdo con la ética ontológica de Jonas (1985, p. 28), el hombre es parte del mundo en todos los aspectos y en este sentido ha adoptado decisiones apartadas de los intereses que le han de caracterizar como un ser que pertenece a lo que Wolsing (2014) denomina un mundo de la vida. Se trata de intereses que abarcan aspectos tales como la preservación, el bienestar y la autorrealización de la especie propia, así como de la vida en su concepción más amplia, lo cual a su vez depende de la asunción de obligaciones morales respecto a los demás. 
Pero ciertamente no hablamos del cumplimiento de dichas obligaciones cuando como especie vemos cómo hay más seres humanos en el mundo pasando hambre de lo que jamás hubo en la historia de la humanidad, como consecuencia de sequías, enfermedades o desastres naturales inducidos muchas veces por el hombre. Es el caso de la contaminación acuífera por la explotación de minerales a través de sustancias como el mercurio, para citar tan solo un caso que engloba este panorama.

Ahora bien, cuando se tiene una expectativa ante este panorama de que la población humana se duplicará en los siguientes siglos y de momento todo pareciera indicar que no podríamos dejarles a las generaciones venideras un patrimonio ambiental (De Siqueira, 2011, p. 99), inevitablemente nos surge la siguiente cuestión ¿qué podemos hacer ahora para cambiar esta proyección?

La respuesta, sin lugar a duda, podemos encontrarla una vez más en uno de los postulados de Jonas (1985, p. 11), en el que sostiene que el ser humano debe obrar de tal modo que los efectos de sus acciones sean compatibles con una vida auténtica y con la expectativa de continuar habitando este planeta.

Para comprender el concepto de vida auténtica en la perspectiva jonasiana, debemos referirnos a un tercer postulado que propone Ayestaran (2008, p. 155) sobre el principio de responsabilidad de Jonas, el cual, acompañando a los ya mencionados postulados de la igualdad intergeneracional y de la justicia ambiental, propugna por la conservación de la integridad del ecosistema y de su biodiversidad. Nos referimos al postulado del respeto por la naturaleza.

En concordancia con este principio, el respeto parte del reconocimiento de axiomas tales como que la prosperidad de la raza humana depende de la prosperidad de la naturaleza; que de la supervivencia de la biósfera en todo su conjunto depende la supervivencia de las futuras generaciones; y que la economía humana es apenas un subsistema de la economía de la naturaleza, por lo que la primera debe encajar en esta, acatando sus leyes, y no aspirar a que la naturaleza sea forzosamente la que lo haga (Ayestaran, 2008, p. 156).

Desde la óptica del derecho, coincidimos con Ruda (2008) en que el gran problema aún no solucionado es el de la catalogación del ambiente como víctima en estricto sentido dentro del sistema de derecho civil en general, y de la responsabilidad civil en especial, así como dentro de otras disciplinas jurídicas. La razón, mientras que al derecho civil ni siquiera le interesan todas las relaciones interpersonales, la responsabilidad civil opera únicamente para aplicar una justicia conmutativa entre quien produce el daño y a quién le perjudica. 
Con lo anterior, queremos decir que, aunque en los últimas décadas la preocupación por el ambiente se ha incorporado en la instrumentación normativa a nivel internacional (García-Castellón, 2006, p. 506), es, en realidad, una preocupación que apenas ha logrado amortiguar los daños irreversibles causados por el hombre, pues el derecho tal y como lo conocemos en la actualidad es incapaz de enderezar la conducta humana hasta tanto no revista al ambiente la condición de víctima.

Para explicar este argumento, a través del deterioro ambiental difuso que afecta a recursos que no le pertenecen a nadie, Ruda (2008) se vale del relato del joven Parsifal y el cisne, que se encuentra en el primer acto del poema de Wolfram von Eschenbach, adaptado en 1887 por Richard Wagner en una de sus célebres óperas.

Parsifal dispara su flecha contra el cisne salvaje que se encontraba inocentemente en el lago, no daña la propiedad de nadie en particular, pero es obvio que destruye uno de los componentes del medio natural y que causa dolor a pesar a los moradores del lugar. En este supuesto, como en otros menos poéticos, la primera impresión es que no tiene sentido hablar de un dominus que soporte el daño o que pueda trasladarlo a otro, como se hace en los daños individuales, ya que no existe propiamente un titular perjudicado. Cabe, por ello, hacer al derecho de la responsabilidad la misma pregunta con que otro de los personajes de dicha ópera increpa al transgresor: el que fue nuestro cisne querido, ¿qué significa ahora para ti? (p. 33).

$Y$ es que, si nos atenemos a las secuelas de las alteraciones ambientales severas, vemos cómo estas han sido más colectivas que individuales, como consecuencia de lo que, en términos de Ruda, es la interdependencia de los recursos naturales, integrados en un sistema único de solución de continuidad, o, lo que es lo mismo, el ecosistema (p. 34). Por ende, es insuficiente que la responsabilidad civil compense individualmente el daño toda vez que este es común y a razón de que no siempre es posible determinar las víctimas concretas afectadas por dichas alteraciones.

En esta misma línea, le han antecedido a Ruda autores como Benjamin (1998), Busnelli (1991) y Prieur (2004), quienes han buscado ampliar el tratamiento jurídico del daño ambiental a un contexto de pluralidad, pues sostienen 
que, más allá del resarcimiento del patrimonio o de la salud de un individuo, es lo colectivo - en tanto el daño ecológico se manifiesta en un sentido puro o público- lo que debe primar.

Otro asunto son los daños reflejo o por rebote, producto de las alteraciones individuales que se pudieron haber presentado y que, para los efectos del derecho de daños, pueden exigirse como daño emergente, lucro cesante e, incluso, como un daño moral (Delgado-Schneider, 2012, p. 49). Un tema de estudio propio que, a efectos de continuar con nuestra línea argumentativa, no se aborda en el presente texto.

Así, el daño ambiental en estricto sentido, o puro, es aquel que se causa o bien al ambiente, o bien a cualquiera de sus elementos, como una realidad autónoma de los valores ortodoxos asociados a la salud y al patrimonio (Delgado-Schneider, 2012, p. 50). En este sentido, podemos afirmar que su titularidad recae en la sociedad, representada por la comunidad afectada y por cada uno de sus miembros. Sociedad que por demás en las últimas décadas ha adquirido una consciencia social del respeto y clama por la salvaguarda al ambiente.

No obstante, es reseñable que a esta consciencia social le contraste de manera notable el estancamiento que en políticas públicas y en materia de responsabilidad civil se ha presentado, salvo en algunos honrosos y calificados esfuerzos, como bien lo apunta Hunter (2005, p. 26).

Es por lo anterior que, al ya referido postulado de Ruda de la insuficiente responsabilidad civil en los daños ambientales, nos sumamos desde la academia, haciendo un llamado de atención para que los esfuerzos e iniciativas normativas tengan en cuenta el principio de responsabilidad jonasiano.

Nos referimos a aquella ética que antepone la supervivencia de la generaciones venideras al impulso del ser humano por actuar contra la naturaleza; a intentar dominarla; a destruir los aspectos de la naturaleza que nos molestan; y apropiarnos selectivamente de lo que creemos nos producirá confort, placer y seguridad (Capriles, 1994). Esta ética le habrá de imponer al legislador un deber de cuidado hacia la naturaleza dada su vulnerabilidad.

Con la presente obra colectiva, la Especialización y la Línea de Investigación en Derecho Ambiental ${ }^{1}$ de la Facultad de Jurisprudencia reafirma ese

\footnotetext{
${ }^{1} \mathrm{El}$ presente texto hace parte del proyecto de investigación: Seguimiento a la actividad legislativa y avances del Derecho Ambiental de Colombia.
} 
llamado de atención desde la contribución de varios juristas colombianos, en el marco del diálogo permanente que desde la academia se da hacia el interior de la sociedad colombiana. Cada autor emprende un tema monográfico que en sí mismo es el reflejo de una problemática relacionada con el ámbito de la responsabilidad civil por daños ambientales. En tal sentido, para otorgarle una consistencia sistemática y lógica a este esfuerzo, el contenido fue estructurado de la siguiente forma.

En primer lugar, Fernando Andrés Pico Zúñiga realiza un acercamiento doctrinal al estudio del daño extrapatrimonial en la responsabilidad civil, a partir de las afectaciones ambientales, atendiendo no solo al ya cuestionado enfoque individual del daño ambiental, sino al enfoque colectivo, con miras a proteger directa e indirectamente la comunidad que se refleja en la naturaleza, así como los derechos presentes y futuros, de acuerdo con la defensa que ha de prestar el ordenamiento jurídico al ambiente.

En la misma línea, Gustavo Adolfo Ortega Guerrero y Tito Simón Ávila Suárez abordan la conceptualización del daño ambiental desde el punto de vista normativo según la evolución desde el derecho ambiental internacional, las disposiciones constitucionales en Colombia y los aspectos normativos de la legislación que desarrollan los instrumentos de regulación directa como el procedimiento sancionatorio ambiental.

Posteriormente, se analiza la conceptualización del daño ambiental que se ha venido desarrollando, comenzando con un ejercicio de jurisprudencia internacional comparada, para concluir con un cotejo de los avances de la jurisprudencia nacional; $y$, finalmente, se presentan algunas cuestiones dogmáticas del daño ambiental, las cuales han establecido su relación con otros conceptos relevantes, como impacto, contaminación y pasivo ambiental, en perspectiva de una teoría de responsabilidad ambiental que supere aquellas patrimonialistas desarrolladas desde la concepción civilista.

En el capítulo correspondiente al estudio de la causalidad adecuada a la imputación objetiva en la responsabilidad civil colombiana, con aplicación particular en la responsabilidad civil ambiental, Sergio Rojas Quiñones y Juan Diego Mojica Restrepo analizan la atribución de un resultado dañoso a partir de un juicio puramente material. En este texto, realizan un primer acercamiento a las teorías de causalidad utilizadas por la jurisprudencia entre el perjuicio irrogado y la actuación del agente, la cual sugieren puede variar o, 
a la vez, arrojar resultados que, a la luz de la equidad y la justicia e, incluso, del sentido común, llegan a resultar exagerados o contraintuitivos.

En ese sentido, es emprendida dicha problemática a fin de, previo recuento de las diferentes soluciones que se le han dado a lo largo de la historia y sus inconvenientes, presentar la que, según estos autores, es la teoría más adecuada para determinar la causalidad en cada caso, superando los defectos que doctrinalmente se le atribuyen a aquellas que la precedieron.

Con esta propuesta, el lector podrá evidenciar cómo, a partir de la diferenciación entre una imputación material y una imputación jurídica u objetiva, se logran resultados más acordes a la noción de justicia que subyace a la responsabilidad civil, que son especialmente aplicables en materias controversiales, como es la causalidad en la responsabilidad civil ambiental. De ahí que el capítulo contenga un importante énfasis en este tema, que se tratará de manera protagónica.

A continuación, Jouline Ropero Patarroyo lleva a cabo un estudio de la cobertura del derecho civil colombiano en los daños por contaminación de hidrocarburos persistentes en el mar. Para ello, luego de examinar el contenido de la actual regulación de la responsabilidad civil en esta materia en Colombia, propone una serie de reflexiones respecto a si esta resulta o no suficiente para resarcir la totalidad de daños que se generan a partir de estos sucesos.

Es de destacar que su planteamiento gira en torno a que dicha regulación, soportada en el régimen internacional de la responsabilidad civil por daños derivados del derrame de hidrocarburos en el mar acogido por Colombia, resulta insuficiente para obtener la reparación de la totalidad de los daños efectivamente causados. Por lo cual afirma que es el juez civil quien debe asumir la facultad de ordenar la reparación de los daños no cubiertos, en desarrollo de los mecanismos disponibles en el derecho civil.

En el capítulo correspondiente a la facultad de prevención en el derecho sancionatorio administrativo ambiental, contenida en la Ley 1333 de 2009, los autores, Andrés Gómez Rey, Gloria Amparo Rodríguez e Iván Vargas Chaves, estudian esta figura con el fin de verificar cómo el derecho ambiental ha venido construyendo una dogmática y reglas propias, escapando de la tradición del derecho administrativo.

Lo anterior con miras a avanzar en el establecimiento y demostración de la forma en la cual el derecho ambiental está creando la dogmática propia necesaria para lograr su independencia y consolidación como un área autónoma 
de la disciplina jurídica. Al respecto, en este ejercicio de reflexión, es posible ver cómo la figura, aparte de estar diseñada por fuera de la teoría general del acto administrativo, también posee particularidades que la hacen única dentro del ordenamiento jurídico colombiano.

La última sección, a cargo de José López Oliva, se dedica al tratamiento del seguro ecológico dentro del régimen de la responsabilidad ambiental en Colombia. Una figura en la cual el legislador ha dispuesto su obligatoriedad, en tanto la actividad de explotación de un recurso o la realización de una obra o actividad requieran de una licencia o permiso ambiental.

Ello, teniendo presente una realidad y es que las empresas o personas naturales en el ejercicio de dicha actividad pueden generar daños al ambiente; $y$, en dicho caso, se hace más que necesario un mecanismo en el que el potencial victimario tenga la posibilidad de trasladar el riesgo inherente a una compañía aseguradora. En este sentido, creemos que, más allá del propósito de salvaguardar su patrimonio, lo que fundamenta esta figura es la garantía misma de reparación del daño ambiental causado.

Como puede observarse, los aportes que son abordados en esta obra colectiva tienen su propia complejidad dentro del estado del arte del derecho ambiental en nuestro país y, por ende, merecen ser estudiados de forma puntual con la finalidad de facilitar su integral comprensión. Vale la pena resaltar que el compromiso de los autores que nos acompañan se refleja en su punto de vista respecto a cada tema particular, buscando con ello contribuir con el estudio de la problemática de los daños ambientales, a propósito del diálogo que al inicio propusimos. Bienvenido el debate al cual hacemos esta contribución desde el desarrollo de los objetivos de la Línea de Investigación en Derecho Ambiental.

\section{Bibliografía}

Abeygunawardena, P., Vyas, Y., Knill, P., Foy, T., Harrold, M., Steele, P., et al. (2002). Poverty and climate change: reducing the vulnerability of the poor through adaptation. Consultation draft presented at the Eighth Conference of Parties to the United Nations Framework Convention on Climate Change, United Nations, New Delhi.

Attfield, R. (1991). The ethics of environmental concern. Athens, GA: University of Georgia Press. 
Ayestaran,I. (2008). The second Copernican revolution in the Anthropocene: an overview. Revista Internacional de Sosteniblidad, Tecnologia y Humanismo, 3, 145-157.

Benjamin,A.(1998). A responsabilidade civil pelo dano ambiental no direito brasileiro e as lições do direito comparado. Revista Roma e America, 6, 129-130.

Busnelli, F. (1991). Illecito civile: estratto dall' aggiornamento I dell'Enciclopedia giuridica. In Enciclopedia giuridica. Roma: Istituto Della Enciclopedia Italiana nell'Enciclopedia 'Giovanni Treccani'.

Capriles, E. (1994). Individuo, sociedad, ecosistema. Mérida (Venezuela): Consejo de Publicaciones de la Universidad de los Andes.

De Siqueira, J. (2001). El principio de responsabilidad de Hans Jonas. Acta Bioethica, 7(2), 277-285.

De Siqueira, J. (2011). Análisis crítico del artículo del prof. Jan Helge Solbakk en el prisma del principio de responsabilidad. Revista Redbioética Unesco, 2(4), 96-100.

Delgado-Schneider, V. (2012). La responsabilidad civil extracontractual por el daño ambiental causado en la construcción u operación de las carreteras. Revista de Derecho, 25(1), 47-76.

García-Castellón, J. (2006). Panorama de la responsabilidad internacional por daño ambiental. In M. Carmona-Lara \& L. Hernández Meza, Temas selectos de derecho ambiental (pp. 407-508). Ciudad de México: Universidad Nacional Autónoma de México.

Grandjean, P. (2013). Science for precautionary decision-marking. In EEA, Late lessons from early warnings: science, precaution, innovation (pp. 635-642). Luxembourg: Publications Office of the European Union.

Hunter, I. (2005). La culpa con la ley en la responsabilidad civil ambiental. Revista de Derecho, 18(2), 9-25.

IPCC. (2007). Fourth assessment report: climate change. Intergovernmental Panel on Climate Change, IPCC Secretariat, Geneva. Recuperado de http://www. ipcc.ch/pdf/assessment-report/ar4/syr/ar4_syr.pdf

Jonas, H. (1985). The imperative of responsibility: in search of an ethics for the technological age. Chicago: University of Chicago Press.

Prieur, M. (2004). Droit de l'environnement. Paris: Dalloz. Ruda, A. (2008). El daño ecológico puro. Madrid: Thomson Aranzadi. 
United Nations Economic Commission for Latin America and the Caribbean (Cepal). (2014). La economía del cambio climático en el Paraguay LC/W.617 - 14-20018. Santiago de Chile: un-Cepal.

Wolsing, P. (2014). ¿Responsibility to nature? Nordicum-Mediterraneum, Icelandic Journal of Nordic and Mediterranean Studies, 8(3). 



\section{Aproximación al estudio del daño extrapatrimonial en la responsabilidad civil derivada del daño ambiental}

Fernando Andrés Pico Zúñiga*

\section{Introducción}

La protección del medio ambiente es fundamental. Los tiempos actuales revelan, a través de fenómenos como el calentamiento global, las fuertes implicaciones de la contaminación en el ambiente y, en consecuencia, exigen que los Estados, las naciones, los pueblos y las personas reciban y se involucren con mayor responsabilidad, más allá de la estrictamente jurídica, en la salvaguardia del entorno natural con el que cuentan (Corte Constitucional de Colombia - $\mathrm{CCC}$ - Sentencia C-632/11).

Los elementos materiales del ambiente son indudablemente trascendentales para la satisfacción de las necesidades del hombre y su desenvolvimiento presente y futuro dentro de la vida (Declaración de Río sobre el Medio Ambiente y el Desarrollo, 1992, principio 30; vin Protocolo de 1996 relativo al Convenio sobre la Prevención de la Contaminación del Mar por Vertimiento de Desechos y otras Materias). De ahí que la protección jurídica de los bienes corpóreos de la naturaleza sea tan relevante, en la medida en que no solo se dirige a preservar los derechos que recaen sobre la integridad física de las cosas en sí mismas consideradas —el agua, el aire, la tierra, etc.—, sino además las consecuencias positivas e intangibles que esos bienes generan en la existencia del hombre —su

\footnotetext{
* Abogado de la Pontificia Universidad Javeriana; magíster en Derecho de la Empresa y de los Negocios de la Universidad de Barcelona (España). Miembro del Grupo de Investigación en Derecho Privado de la Facultad de Ciencias Jurídicas de la Pontificia Universidad Javeriana; coautor del libro Solidarismo contractual. El deber de cooperación y su repercusión en la responsabilidad civil y autor de artículos investigativos publicados en revistas como Vniversitas, Universitas Estudiantes y Elementos de Juicio; columnista del periódico Ámbito Jurídico. Correo electrónico: fpz14@hotmail.com
} 
tranquilidad, su dignidad, la garantía de supervivencia-, lo que podría denominarse corolarios y/o derechos inmateriales dela naturaleza.

Cuando se trata de resguardar los mencionados derechos ecológicos — patrimoniales y extrapatrimoniales - desde el ámbito del derecho civil y en particular la responsabilidad civil, la pregunta que muchos se formulan es: qué tiene que ver el derecho civil con el ambiente, máxime cuando estos últimos, primero, se tratan de derechos de estirpe preponderantemente colectiva; segundo, su protección, especialmente inmaterial, le ha correspondido históricamente al derecho público; y, tercero, la legislación decimonónica del derecho civil no le otorga una defensa clara y concreta.

En efecto, aunque los derechos ambientales son por naturaleza colectivos, es claro, para un importante sector doctrinal, que el derecho público es insuficiente para salvaguardar al medio natural, más aún, para resarcir los daños individuales derivados del perjuicio ambiental — los denominados daños ambientales impuros-. A la luz de ello, la jurisprudencia colombiana en materia de responsabilidad civil, gracias a la cláusula general de responsabilidad, bajo el artículo 2341 del Código Civil (cc), así como algunas disposiciones especiales que se acercan a la materia ambiental dentro del ordenamiento común, artículos 2356 del cc, ha reconocido la responsabilidad civil ambiental, que se encamina a proteger preponderantemente los intereses privados e intrínsecamente los colectivos.

De esta manera los daños extrapatrimoniales o no patrimoniales de carácter individual adquieren una vital relevancia en la medida en que su protección se dirige no solo a garantizar las haciendas particulares de la víctima, sino también a salvaguardar, interior e indirectamente, los de la colectividad, presentes y futuros, a propósito de completar la defensa que presta el ordenamiento jurídico al ambiente.

A sabiendas de la trascendencia humana que envuelve la materia y ubicándose desde el ámbito jurídico civil, interesa bajo este artículo aproximarse, a manera de invitación, al análisis de los daños no patrimoniales de carácter individual que se generan como consecuencia de la transgresión al medio natural. Para ese efecto, primero, se abordarán someramente los elementos más característicos de la responsabilidad civil ambiental, con el objetivo de ubicarse en el estudio propuesto. En segundo lugar, a la luz de la jurisprudencia y la doctrina, se propondrán los conceptos de daño no patrimonial y daño ambiental, para efectos de establecer, dentro del ordenamiento civil, su fuente 
y características más relevantes. Por último, en la tercera parte, se examinarán sucintamente los presupuestos específicos que configuran la compensación del daño ambiental.

\subsection{Breve referencia a la responsabilidad civil ambiental}

A modo ilustrativo y de ubicación, se pasan a dar unos breves lineamientos acerca de la responsabilidad civil ambiental en Colombia.

Es importante empezar por afirmar que el papel que hoy juega la responsabilidad civil en la protección del ambiente es residual, ya que su finalidad es la de resolver los conflictos entre particulares y, en consecuencia, conforme a sus intereses privados (Díez-Picazo, 2011, p. 432).

En ese sentido, mediante el título de responsabilidad civil ambiental se estructura el tipo de responsabilidad a la que habrán de enfrentarse aquellos sujetos que, por medio de la creación de riesgos ambientales, causen un daño a las personas —en sus bienes y/o intimidad-, así como al equilibrio ecológico. Por esa razón destaca Díez-Picazo que

[s]e deben diferenciar los daños por contaminación de los daños estrictamente ecológicos, porque las soluciones válidas para los unos no lo son para los otros. De este modo, por daño por contaminación, debemos entender aquellas lesiones patrimoniales y morales, que como consecuencia de un accidente ambiental afectan a la persona y a sus bienes. Daños ecológicos, por su parte, son aquellos sufridos por el medio ambiente que, como consecuencia de un accidente causado por la mano del hombre, afectan a su equilibrio natural (2011, p. 432).

Así, el derecho civil, por intermedio de la responsabilidad civil ambiental, establece los criterios y presupuestos de la responsabilidad derivada de los daños por contaminación - tanto patrimoniales como extrapatrimoniales- que se le causan a una persona in concreto. Sin embargo, de manera indirecta y más bien con poca demostración práctica, como lo han vislumbrado los enfoques del igualitarismo ecológico (ecological egalitarianism) o ecologismo profundo (deepecology), la responsabilidad civil ambiental se dirige en cierta medida hacia la protección del medio ambiente como titular de derechos (Ruda González, 2008, p. 46; Cabanillas Sánchez, 1996, pp. 39 y ss.; sccsJ, sentencia del 14 de octubre de 2011, p. 30). 
En esa línea, la Sala de Casación Civil de la Corte Suprema de Justicia de Colombia (sccsj), amparada en doctrina especializada, determina que el daño ambiental, que interesa a la responsabilidad civil dentro del derecho privado, es el que se ha conocido e identificado con el apelativo de daño ambiental impuro, ya que se trata del detrimento consecuencial, indirecto o consecutivo de otros derechos, bienes o intereses particulares a consecuencia del quebranto al ambiente, y cuyo titular no es la colectividad in abstracto, sino una, o varias, o muchas personas individualmente consideradas (sccsJ, sentencia del 16 de mayo de 2011). Se verá con mayor detenimiento en un acápite posterior.

Ahora bien, como lo identifica Tamayo Jaramillo, es posible que la contaminación ambiental dé lugar a una responsabilidad de tipo contractual. No obstante, son mucho más frecuentes las hipótesis de contaminación ambiental que se enmarcan dentro de los presupuestos de la responsabilidad extracontractual (Tamayo Jaramillo, 2007, p. 644). De ahí que este acápite de presentación se centre en esta última temática, que podría considerarse de mayor interés a la luz del asunto que se propone abordar.

Así las cosas, la responsabilidad civil extracontractual en materia ambiental, como lo ha establecido la jurisprudencia nacional (sccsJ, sentencia del 16 de mayo de 2011, sentencia del 30 de abril de 1976, cLII, pp. 111 y ss.), tiene

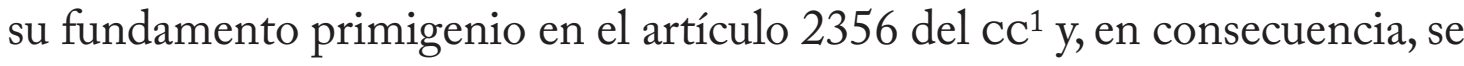
sitúa dentro del régimen jurídico de las actividades peligrosas en virtud del riesgo congénito a la acción u omisión dañosa que, aunque puedan ser lícitas, útiles y necesarias, no autorizan a generar perjuicios a los demás.

No distante del precepto normativo común señalado, se encuentra el artículo 16 de la Ley 23 de 1973, la cual sirvió como fundamento al Código de Recursos Naturales expedido en 1974 —Decreto 2811—, que establece

\footnotetext{
${ }^{1}$ Es importante destacar que la disposición normativa señalada no es la única que fundamenta toda la estructura de la responsabilidad civil extracontractual en materia ambiental dentro del ordenamiento jurídico colombiano. En efecto, es dable encontrar otras normas que sostienen, de una parte, la protección del medio ambiente y, de la otra, los derechos de las personas frente a este, preponderantemente en el ámbito civil. Así las cosas, cabe mencionar: i) el artículo 88 de la Constitución Política de Colombia de 1991; ii) el artículo 2341 del cc, en casos de responsabilidad por incumplimiento de normas ambientales; iii) el artículo 669, en los eventos de responsabilidad civil derivada del derecho de dominio; y iv) el Código de Recursos Naturales (Tamayo Jaramillo, 2007).
} 
una responsabilidad objetiva a cargo del Estado y de los particulares cuando alguno de ellos atente contra el patrimonio colectivo de los recursos naturales. ${ }^{2}$

En ese sentido, ha dicho nuestra sccsj que bajo este régimen“" $[. .$.$] basta$ demostrar el daño y la relación de causalidad para obtener la reparación 'del perjuicio sufrido, salvo prueba de fuerza mayor, o caso fortuito o de la culpa exclusiva de la propia víctima', [...]"'(sccsJ, sentencia del 16 de mayo de 2011).

Así, quien responde es el guardián, como acontece en los demás supuestos de la responsabilidad por actividades peligrosas, en la medida en que tiene el poder intelectual de control y dirección de la acción. Ahora, "[...] puede suceder que no sólo el dueño de la actividad contaminante sea su guardián sino que dicho poder se encuentre, también, en cabeza de un tercero, en cuyo caso, ambos serán responsables solidariamente" (Tamayo Jaramillo, 2007, p. 646).

Por último, merece hacerse una brevísima referencia a la teoría del abuso del derecho como fuente de responsabilidad. De esta forma, cuando se prueba que la causa del daño ambiental es el comportamiento abusivo, bien en forma culposa o dolosa, por parte del dueño de la actividad contaminante, lo aplicable es la responsabilidad con culpa probada de que trata el artículo 2341 del cc (Tamayo Jaramillo, 2007, p. 647; Mazeaud, Tunc y Chabas, 1965). En consecuencia, bajo esta modalidad de responsabilidad se requiere, a diferencia de la actividad peligrosa, que el demandante acredite cada uno de los elementos constitutivos de responsabilidad — culpa, daño y nexo causal—, particularmente el atinente al de la culpa, sin la cual no puede atribuirse responsabilidad civil ambiental por la vía de la teoría del abuso del derecho.

\subsection{El daño extrapatrimonial en el derecho del medio ambiente}

Para tratar la temática que se pretende bajo este acápite, se estima preciso, primero, aproximarse a los conceptos de daño no patrimonial y daño ambiental, para luego, y en segundo lugar, adentrarse a la noción y características más relevantes del perjuicio extrapatrimonial de carácter ambiental.

\footnotetext{
${ }^{2}$ En los siguientes términos se expresa el señalado artículo 16 de la Ley 23 de 1973, "por el cual se conceden facultades extraordinarias al Presidente de la República para expedir el Código de Recursos Naturales y de Protección al Medio Ambiente y se dictan otras disposiciones": "Artículo 16. El Estado será civilmente responsable por los daños ocasionados al hombre o a los recursos naturales de propiedad privada como consecuencia de acciones que generan contaminación o detrimento del medio ambiente. Los particulares lo serán por las mismas razones y por el daño o uso inadecuado de los recursos naturales de propiedad del Estado".
} 
El concepto de daño extrapatrimonial o no patrimonial. Como enseña la sCcsJ,

[...] el daño podrá recaer sobre bienes susceptibles per sede evaluación pecuniaria inmediata u objetiva o respecto de "intereses que según la conciencia social no son susceptibles de valorización económica” (Bianca,1999: 166), esto es, afectar valores vitales, consustanciales, inmanentes e intrínsecos del sujeto, inherentes a su personalidad y esfera afectiva, ora extrínsecos y externos al mismo, es decir, ostentar naturaleza material (Dommages matériels), ora inmaterial (Dommages immatériels), bien patrimonial (Vermögensschaden), ya extrapatrimonial (nicht Vermörgensschaden) (sccsJ, sentencia del 18 de septiembre de 2009).

En ese sentido, son innumerables, así como diversas, las definiciones que se le han ofrecido al daño no patrimonial. Es más, un sector importante de la doctrina ha igualado, de antaño, los conceptos de daño extrapatrimonial y daño moral lato sensu ${ }^{3}$ (Mazeaud, Mazeaud y Tunc, 1961, p. 423). Al respecto explica De Ángel Yágüez que "[1] os llamados daños morales son los infligidos a las creencias, los sentimientos, la dignidad, la estima social o la salud física; en suma, a los que se suelen denominar derechos de la personalidad o extrapatrimoniales"(1993, p. 675).

Sin perjuicio de la dificultad de limitación de los conceptos, "[e]1 daño no patrimonial no puede ser definido más que en contraposición al daño patrimonial. Daño no patrimonial, en consonancia con el valor negativo de su misma expresión literal, es todo daño privado que no puede comprenderse en el daño patrimonial, por tener por objeto un interés no patrimonial, o sea, que guarda relación a un bien no patrimonial" (De Cupis, 1975, p. 122).

De esta manera, la patrimonialidad es el atributo distintivo del daño bajo la categoría que se estudia y, en consecuencia, se refiere, siguiendo a De Cupis, a una necesidad de carácter económico, por lo que patrimonial es, in concreto, cualquier bien exterior respecto de la persona, que tenga el atributo

\footnotetext{
${ }^{3}$ Se ha entendido así porque, como se sabe, en la actualidad existe una gran proliferación de daños extrapatrimoniales — daño a la salud, vida en relación, entre otros—, reconocidos por la doctrina y la jurisprudencia, que amplían el espectro de los llamados, in extenso, daños morales (De Cupis, 1975, pp. 122 y ss.).
} 
de clasificarse dentro de la riqueza material, esto es, valorable en dinero, e idóneo para satisfacer una necesidad económica (1975, p. 121). Por ende, cuando se trata de daños extrapatrimoniales, se describe y delimita a aquella serie de perjuicios causados al sujeto que no tienen ni cumplen una necesidad de tipo económico y que, por efecto, son de difícil tasación y resarcimiento.

El concepto de daño ambiental. De forma muy concreta, por daño ambiental puede entenderse el menoscabo o perjuicio que sufre el medio ambiente. A partir de esta concepción escueta e inicial, surgen dos preguntas trascendentales a propósito de abordar con mayor suficiencia la noción objeto de análisis dentro del derecho y, particularmente, dentro del ámbito de la responsabilidad civil, a saber: i) ¿qué se entiende por medio ambiente? y ii) ¿¿cuál detrimento ambiental es el que interesa o protege la responsabilidad civil?4

Ahora bien, sin perjuicio de las acepciones legales, "[...] por medio ambiente se puede entender el entorno que rodea al hombre y que está integrado por el agua, el aire, el suelo, la fauna, la flora y el paisaje, y cuya alteración influye en la vida y desarrollo humano, ya que afecta no sólo a las condiciones favorables para la conservación de su salud, sino también a su calidad de vida" (Yanguas Montero, 2006, p. 36).

ii) El daño ambiental que importa a la responsabilidad civil. Como enseña la sccsJ,

${ }^{4}$ i) El medio ambiente. En Colombia, a diferencia de lo que acontece en otros ordenamientos como el español, se encuentran definidos, por el derecho positivo, los conceptos atinentes al medio ambiente y su detrimento. Así, a la luz del artículo $2^{\circ}$ de la Ley 23 de 1973 — por el cual se conceden facultades extraordinarias al Presidente de la República para expedir el Código de Recursos Naturales y de Protección al Medio Ambiente y se dictan otras disposiciones-, "[...] el medio ambiente está constituido por la atmósfera y los recursos naturales renovables". Por su parte, la contaminación ambiental, definida en el artículo 4º de la Ley 23 de 1973 (ver también el artículo 8º del Decreto 2811 de 1974 —por el cual se dicta el Código Nacional de Recursos Naturales Renovables y de Protección al Medio Ambiente-, que la define en términos muy similares ), es "[...] la alteración del medio ambiente por sustancias o formas de energía puestas allí por la actividad humana o de la naturaleza, en cantidades, concentraciones o niveles capaces de interferir con el bienestar y la salud de las personas, atentar contra la flora y la fauna, degradar la calidad del medio ambiente o afectar los recursos de la nación o de particulares"; y, por daño ambiental, en lo atinente a la fijación de las tasas retributivas, siguiendo lo dispuesto en el artículo 42 de la Ley 99 de 1993 — por la cual se crea el Ministerio del Medio Ambiente, se reordena el sector público encargado de la gestión y conservación del medio ambiente y los recursos naturales renovables, se organiza el Sistema Nacional Ambiental (sinA) y se dictan otras disposiciones-, "[...] el que afecte el normal funcionamiento de los ecosistemas o la renovabilidad de sus recursos y componentes; [...]" (scCsJ, sentencia del 16 de mayo de 2011). 
[...] el daño ambiental en rigor recae sobre el ambiente, esto es, un valor, interés o derecho público colectivo, supraindividual o más allá del individuo, cuyo titular es la colectividad en general, no un particular, ni sujeto determinado, o sea, el quebranto afecta no a una, sino a todas las personas, y "exclusivamente el medio natural en sí mismo considerado, es decir, las 'cosas comunes' que en ocasiones hemos designado como 'bienes ambientales', tales como el agua, el aire, la flora y la fauna salvaje. Se trata entonces de aquello que se ha convenido llamar 'perjuicios ecológicos puros" (Viney y Jourdain, 1998, p. 55; a la locución 'daño ambiental puro' refiere la Ley 491 de 1999, artículo 20, inciso 2, respecto del 'seguro ecológico') (sccsj, sentencia del 16 de mayo de 2011).

Aunque el daño ambiental es por naturaleza colectivo, en la medida en que lastima a los bienes ambientales de provecho general, también puede generar lesiones directas o indirectas a los intereses individuales de los particulares.

Así, la doctrina y la jurisprudencia han distinguido, como se ha visto, al daño ambiental puro, menoscabo que se le infringe exclusivamente al medio natural, del llamado daño ambiental impuro, atinente al "[...] detrimento consecuencial, conexo, reflejo, indirecto o consecutivo de otros derechos, bienes o intereses particulares a consecuencia del quebranto al ambiente, y cuyo titular no es la colectividad in abstracto, sino una, o varias, o muchas personas individualmente consideradas" (sccsJ, sentencia del 16 de mayo de 2011; Luquin Bergareche, 2005, pp. 136 y ss.).

Es precisamente esta última categoría, la del daño ambiental impuro, la que interesa a la responsabilidad civil a efectos de resarcir los perjuicios ocasionados. En efecto, como indica Yanguas Montero, "[d]esde una óptica privatística, sólo son relevantes los daños que, degradando el medio ambiente, perjudican a un interés particular" (Yanguas Montero, 2006, p. 37; Álvarez Lata, 2002, p. 777; Drago, 1974, p. 13).

Ahora bien, sin perjuicio del entendimiento anterior, al que se suman tratadistas como Reyes López (2001, p. 214), Macías Castillo (2004, p. 202) y Prieur (1991, p. 729), para otro sector doctrinal solo merecen el calificativo de ambientales aquellos perjuicios ecológicos que exceden de los intereses 
individuales y de los que se encarga el derecho público 5 (Jordano Fraga, 2001, p. 287; Conde Antequera, 2004, p. 26). Esta misma comprensión parece tenerla nuestra sccsJ, quien, bajo la tan relevante sentencia del 16 de mayo de 2011, considera que

[...] cuando el daño ambiental ocasiona también un daño a intereses singulares, particulares y concretos de un sujeto determinado o determinable, el menoscabo atañe y afecta estos derechos, a su titular y su reparación versa sobre los mismos, o sea, mira al interés particular y no colectivo. En este supuesto, no se trata de daño ambiental, sino del detrimento de otros derechos, es decir, la conducta a más de quebrantar bienes ambientales, lesiona la esfera jurídica individual de una persona o grupo de personas, ya determinadas, ora determinables. Compréndase, por ende, la nítida diferenciación del daño ambiental y el inferido a otros intereses particulares como consecuencia directa o indirecta, inmediata, consecuente, refleja, conexa o de rebote del mismo evento dañoso.

Conforme a lo dicho hasta aquí, el perjuicio ambiental relevante para la responsabilidad civil es aquel que, afectando al medio natural, menoscaba de forma directa o indirecta los derechos individuales de la persona. En consecuencia, la denominada responsabilidad civil ambiental, tras la vulneración de tales derechos, procura resarcirlos.

Hacia la noción y características del daño extrapatrimonial ambiental en el campo de la responsabilidad civil. A la luz de lo analizado en las líneas precedentes, el daño no patrimonial ambiental puede ser definido como el detrimento o perjuicio que afecta los bienes inmateriales de la persona como consecuencia de una alteración al medio ambiente. Sus requisitos y/o características no distan de las que la doctrina y la jurisprudencia le han reconocido a los daños en general (Yanguas Montero, 2006, p. 61; Corte Suprema de Justicia, Sala de Negocios Generales, sentencia del 27 de septiembre de 1946, sentencia del 29 de agosto de 1960). Así, son particularidades del daño extrapatrimonial

\footnotetext{
5 "Según esta concepción, no puede aplicarse el calificativo de ambientales ni revisten ningún tipo de especialidad los perjuicios que, aunque se originen como consecuencia de la alteración de un elemento del medio ambiente, afectan a intereses particulares"(Yanguas Montero, 2006, pp. 38 y 39).
} 
ambiental las siguientes, entre otras tantas que la doctrina ha identificado (Pérez Fuentes, 2009, pp. 36 y 37).

a) Cierto. Este atributo del daño ha sido explicado por la sccsj en los siguientes términos:

[E]n tratándose del daño, (...) la indemnización exige la certeza del detrimento, o sea, su verdad, existencia u ocurrencia tangible, incontestable o verosímil, ya actual, ora ulterior, acreditada por el demandante como presupuesto ineluctable de la condena con pruebas idóneas en su entidad y extensión. La certidumbre del daño, por consiguiente, es requisito constante ineludible de toda reparación y atañe a la real, verídica, efectiva o creíble conculcación del derecho, interés o valor jurídicamente protegido, ya actual, bien potencial e inminente, mas no eventual, contingente o hipotética (Cas. Civ., sentencias del 11 de mayo de 1976, 10 de agosto de 1976, G.J. 2393, pp. 143 y 320) (sccsJ, sentencia del 9 de septiembre de 2010).

Así, la certeza del daño extrapatrimonial ambiental implica la necesidad de que el resultado lesivo sea objetivamente efectivo, presente o futuro, en cualquiera de los derechos y/o bienes inmateriales de la persona afectada.

b) Inmediato o directo. El carácter inmediato o directo del daño hace alusión, en realidad, al nexo de causalidad —elemento constitutivo de responsabilidad- (De Cupis, 1975, p. 247; Ternera Barrios y Ternera Barrios, 2008). De este modo, y dentro del ámbito objeto de análisis, debe existir una relación de causalidad - fenómeno jurídico de causa y efecto- entre el daño ecológico y el daño extrapatrimonial acusado. En otras palabras, el perjuicio inmaterial o material que padece la persona debe ser consecuencia seguida, conexa del hecho dañoso ambiental (sccsj, sentencia del 16 de mayo de 2011).

c) Antijurídico. El daño debe ser ilícito, esto es, no estar conforme a los mandamientos y lineamientos dispuestos en el ordenamiento jurídico. ${ }^{6} \mathrm{De}$

\footnotetext{
6 "En nuestro ordenamiento jurídico se ha planteado la cuestión de si la antijuridicidad constituye un requisito de responsabilidad civil extracontractual, siendo mayoritaria la opinión de quienes consideran que el comportamiento que engendra la obligación de reparar un daño ha de ser antijurídico o ilícito. Desde otra perspectiva, se ha mantenido, de forma acertada a nuestro juicio, que el problema no estriba en calificar como ilícita la actividad inicial de la que el daño pueda ser resultado, ya que hasta que el daño no se produzca no hay nada que indemnizar. Lo que hay que determinar, por tanto, no es la
} 
este modo, el daño que afecta los bienes jurídicos inmateriales de la víctima debe a su vez transgredir las normas ambientales en el caso específico de que se trate.

Ahora, íntimamente ligado al concepto de antijuridicidad, se encuentra el asunto relativo a la tolerabilidad del daño. Así, en el campo de análisis, "[a]1 daño ambiental que excede la esfera patrimonial se le exige que sea intolerable, ya que si no merece esta consideración, no surgirá la responsabilidad y, por lo tanto, no será susceptible de indemnización por cuanto no será considerado antijurídico. Esta exigencia implica que no puedan derivarse daños resarcibles de las situaciones de mera molestia, aburrimiento, enojo o enfado"7 (Yanguas Montero, 2006, p. 131; Cabanillas Sánchez, 1996, p. 145).

\subsection{La compensación del daño extrapatrimonial en el derecho del medio ambiente}

En Colombia, al igual que en otros ordenamientos, como el español, la reparación de los daños extrapatrimoniales ha encontrado asidero normativo en la cláusula general de responsabilidad civil, artículo 2341 del cc.

Así, una vez cumplidos los requisitos constitutivos de la responsabilidad civil ambiental, surge la obligación de indemnizar y/o compensar los daños causados.

De este modo, dentro del campo de la compensación del daño no patrimonial derivado del perjuicio al medio ambiente, se plantean varias cuestiones

conformidad con el ordenamiento jurídico de una conducta — hay actos perfectamente acordes con el derecho positivo, tales como el desarrollo de un actividad fabril, de los que nadie duda que pueda surgir responsabilidad — sino si los daños en sí mismo considerados son o no lícitos. Puede, en consecuencia, afirmarse que la ilicitud constituye una característica del daño resarcible”(Yanguas Montero, 2006, pp. 129 y 130; Cabanillas Sánchez, 1992). "Si resulta necesario, para obtener reparación del atentado contra los sentimientos afectivos, justificar un pesar real y profundo, todos los que experimenten tal pena no son admitidos a alegarlo ante la justicia. De igual modo que nadie puede pedir reparación del daño material que sufre él cuando el interés lesionado no fuere 'legítimo', así tampoco puede ser invocado el pesar más que si surge de la ruptura de una situación 'legítima'; es decir, conforme a la ley y a la moral" (Mazeaud, Mazeaud y Tunc, 1961, p. 463).

${ }^{7}$ Es importante destacar la enorme dificultad y problemática que enmarca el hecho de establecer el límite de la tolerabilidad, el cual una vez sobrepasado permite que los perjuicios sean resarcidos o compensados. Sin perjuicio de ello, Yanguas propone algunos lineamientos a efectos de determinar la tolerabilidad del daño. Así lo explica: "[...] para determinar si un daño es o no tolerable, se ha de atender a la entidad del daño (aunque en ocasiones se examina la entidad de la propia acción generadora del daño), a la conciencia social y a los criterios relativos a las circunstancias de cada caso"(Yanguas Montero, 2006, p. 136). 
jurídicas de suma trascendencia, de las cuales podemos resaltar: i) los modos de reparar los daños - pecuniaria y en especie o in natura - ; y ii) la valoración del daño extrapatrimonial.

i) Los modos de reparar los daños. Como bien se sabe, la función primordial de la responsabilidad civil es la de lograr que el perjudicado quede indemne de los daños sufridos.

Aun así, los artículos 2341 y siguientes del cc, reguladores de la responsabilidad civil, no determinan el cómo o la manera en que debe realizarse dicha indemnización. En consecuencia, y para ello, se han planteado dos formas distintas: la reparación a través del mismo bien u objeto dañado - reparación en especie, in natura o específicay la reparación por medio de la entrega de una suma de dinero al agraviado — reparación por equivalente o pecuniaria-.

Como explica Yanguas, “[...] la reparación en especie es aquella que tiene por finalidad reponer al perjudicado a un estado igual al que poseía antes de que se produjera la causación del perjuicio, pudiendo realizarse, en la práctica, por medio de actividades constitutivas de un dare o de un facere. Implica, por tanto, la puesta en práctica de la actividad precisa para reponer lo dañado al estado en que se encontraba con anterioridad al daño" (Yanguas, 2006, p. 196). Cuando la reparación in natura resulte excesivamente gravosa para el causante del daño o no sea posible, se confiere una cantidad económica. De esta forma, bajo la reparación equivalente, no se reintegra el objeto lesionado a su estado inicial u original, sino que se le sustituye por un semejante pecuniario.

Ahora bien, a sabiendas de lo anterior, en el ámbito de la reparación de los daños derivados del menoscabo ambiental, se ha entendido que, en la medida de las posibilidades, debe imponerse la indemnización in natura, ya que debe prevalecer la restitución de las cosas a su estado original. Sin embargo, esta alternativa no siempre es posible. Comúnmente en las hipótesis en las que se generan perjuicios ambientales, y muy especialmente de carácter extrapatrimonial (piénsese, a manera de ejemplo, en los ruidos provenientes de una fábrica que no deja dormir a las personas de un barrio), no cabe la reparación en especie o in natura, de una parte, porque, como se anticipaba, el 
bien objeto de la trasgresión no permite retrotraer los efectos a su estado inicial, o porque, de la otra, la reparación in natura resulta excesivamente gravosa para el causante del daño. Estas situaciones, presentes con mucha frecuencia, hacen que deba acudirse a la indemnización pecuniaria por ser el único método para compensar el daño sufrido por el lesionado. En definitiva, la compensación económica se vuelve la forma más común de reparación del daño extrapatrimonial derivado del perjuicio al ambiente (Yanguas, 1996, pp. 196 y ss.).

ii) La valoración del daño extrapatrimonial. A sabiendas que desde el punto de vista práctico prima, para la reparación de los daños no patrimoniales emanados del menoscabo a la naturaleza, la concesión de una indemnización — reparación equivalente- sobre la reparación in natura o en especie, se hace necesario establecer el valor, a propósito de resarcir los perjuicios causados. De esta manera, sobresale tal vez el asunto que reviste mayor dificultad dentro del análisis del daño no patrimonial en general, el relativo a su estimación o cuantificación pecuniaria.

Así, la doctrina y la jurisprudencia han establecido dos criterios y/o elementos, íntimamente atados, para determinar el valor de la compensación: las bases y el quantum indemnizatorio. Ello en la medida en que en nuestro ordenamiento civil no existen lineamientos generales establecidos que permitan la cuantificación de los perjuicios ambientales y extrapatrimoniales, por lo cual, se reitera, la valoración constituye una materia de especial complejidad al concurrir factores de política legislativa, seguridad jurídica, justicia material y otros tantos no menos importantes relacionados con la técnica legal (Yanguas, 1996, pp. 202 y 203; García López, 1990, p. 150; De Ángel Yágüez, 1989 , p. 50).

En el ámbito colombiano, siguiendo el estudio realizado por Isaza Posse, el Consejo de Estado de Colombia ha considerado, en lo que refiere a la indemnización y tasación de los perjuicios no patrimoniales, que

[...] "hay lugar a indemnizar todo perjuicio moral sin importar su origen, inclusive el derivado de la pérdida de bienes materiales o el causado con el incumplimiento de las obligaciones derivadas del 
contrato, siempre que, como sucede en relación con toda clase de perjuicios, aquellos sean demostrados en el proceso". Para que haya lugar a la reparación del perjuicio basta que el padecimiento sea fundado, sin que se requiera acreditar ningún requisito adicional. Corresponde al juez tasar discrecionalmente la cuantía de su reparación, teniendo en cuenta las condiciones particulares de la víctima y la gravedad objetiva de la lesión. La intensidad de daño es apreciable por sus manifestaciones externas, por esto se admite para su demostración cualquier tipo de prueba (Consejo de Estado colombiano, sentencia de la Sección Tercera del 5 de diciembre de 2006; Isaza Posse, 2009, pp. 45 y ss.).

La sccsj ha establecido algunos montos y baremos aplicables para la compensación de los daños extrapatrimoniales in extenso (sccsJ, sentencia del 7 de septiembre de 2001, sentencia del 30 de junio de 2005, sentencia del 20 de enero de 2009). Sin perjuicio de ello, cabe resaltar que la reparación de los daños extrapatrimoniales derivados del daño ambiental no ha sido un tema suficientemente tratado por la jurisprudencia colombiana. De ahí que se pueda concluir, a luz de lo indicado por el Consejo de Estado patrio y la doctrina, que, para efectos de restituir al dañado, el juzgador deberá establecer, con fundamentos en las pruebas que acrediten la gravedad objetiva de la lesión y las condiciones de la víctima - las bases-, el monto o valor de la compensación -quantum-.

\section{Bibliografía}

Álvarez Lata, N. (2002). El daño ambiental. Presente y futuro de su reparación. Revista de Derecho Privado.

Bianca, C. (1999). Diritto civile: la responsabilità. Milán: Giuffrè.

Cabanillas Sánchez, A. (1992). La responsabilidad por daños ambientales según la jurisprudencia civil. En Estudios de derecho civil en homenaje al profesor Dr. José Luis Lacruz Berdejo. Barcelona: Bosch.

Cabanillas Sánchez, A. (1996). La reparación de los daños al medio ambiente. Pamplona: Editorial Aranzadi.

Colombia, Consejo de Estado, Sección Tercera. Sentencia del 5 de diciembre de 2006. Expediente 16.347.

Colombia, Corte Constitucional. Sentencia C-632 de 2011. 
Colombia, Corte Suprema de Justicia, Sala de Casación Civil. Sentencia del 7 de septiembre de 2001. Expediente 6171.

Colombia, Corte Suprema de Justicia, Sala de Casación Civil. Sentencia del 30 de junio de 2005. Expediente 68001-3103-005-1998-00650.01.

Colombia, Corte Suprema de Justicia, Sala de Casación Civil. Sentencia del 20 de enero de 2009. Expediente 17001310300519930021504.

Colombia, Corte Suprema de Justicia, Sala de Casación Civil. Sentencia del 18 de septiembre de 2009. Referencia: 20001-3103-005-2005-00406-01.

Colombia, Corte Suprema de Justicia, Sala de Casación Civil. Sentencia del 9 de septiembre de 2010. Referencia: 17042-3103-001-2005-00103-01.

Colombia, Corte Suprema de Justicia, Sala de Casación Civil. Sentencia del 16 de mayo de 2011. Referencia: 52835-3103-001-2000-00005-01.

Colombia, Corte Suprema de Justicia, Sala de Casación Civil. Sentencia del 14 de octubre de 2011. Referencia: C-6800131030032005-00277-01.

Colombia, Corte Suprema de Justicia, Sala de Negocios Generales. Sentencia del 27 de septiembre de 1946.

Colombia, Corte Suprema de Justicia, Sala de Negocios Generales. Sentencia del 29 de agosto de 1960.

Colombia, Corte Suprema de Justicia, Sala de Negocios Generales. Sentencia del 30 de abril de 1976, cLII.

Conde Antequera,J. (2004). El deber jurídico de restauración ambiental. Granada: Editorial Comares.

De Ángel Yágüez, R. (1993). Tratado de responsabilidad civil. Madrid: Civitas.

De Cupis, A. (1975).El daño. Teoría general de la responsabilidad civil. Barcelona: Editorial Bosch.

Díez-Picazo, L. (2011). Fundamentos del derecho civil patrimonial. V. La responsabilidad civil extracontractual. Pamplona: Editorial Civitas, Thomson Reuters.

Drago, R. (1974). Prefacio a la obra de Girod, P. La réparation du dommage écologique. París: Editorial LGDJ.

Isaza Posse, M. (2009).De la cuantificación del daño, manual teórico-práctico. Bogotá: Editorial Temis.

Jordano Fraga,J. (2001). Administración y responsabilidad por daños al medio ambiente: la construcción del régimen jurídico de los daños ambientales. Madrid: Editorial Escuela Judicial Consejo General del Poder Judicial.

Luquin Bergareche, R. (2005). Mecanismos jurídicos civiles de tutela ambiental. Navarra: Thomson Aranzadi. 
Macías Castillo, A. (2004). El daño causado por el ruido y otras inmisiones. Madrid: La Ley.

Mazeaud,H., Mazeaud, L., \&Tunc, A. (1961). Tratado teórico y práctico de la responsabilidad civil delictual y contractual. T. I, Vol. I. Buenos Aires: Editorial Ediciones Jurídicas Europa-América.

Pérez Fuentes, G. (2009). La responsabilidad civil por daños al medio ambiente en el derecho comparado. Revista Prolegómenos, 12(23), 35-42.

Prieur, M. (1991). Droit de l'environnement. Paris: Editorial Dalloz.

Reyes López,M.J.(2001).Derecho ambiental español. Valencia:Tirant lo Blanch.

Ruda González, A. (2008). El daño ecológico puro. La responsabilidad civil por el deterioro del medio ambiente, con especial atención a la Ley 26/2007, de 23 de octubre, de responsabilidad medioambiental. Pamplona: Thomson Aranzadi.

Tamayo Jaramillo, J. (2007).Las acciones constitucionales contra la contaminación ambiental en el derecho colombiano: responsabilidad civil. Bogotá: Editorial Rubinzal-Culzoni.

Ternera Barrios, L., \& Ternera Barrios, F. (2008). Breves comentarios sobre el daño y su indemnización. Revista Opinión Jurídica, 7(13).

Viney, G., \& Jourdain, P. (1998). Traité de droit civil. Les conditions de la responsabilité. Paris: LGDJ.

Yanguas Montero, G. (2006). El daño no patrimonial en el derecho del medio ambiente. Pamplona: Thomson Civitas. 


\title{
2. De la causalidad adecuada a la imputación objetiva en la responsabilidad civil colombiana Aplicación particular en la responsabilidad civil ambiental
}

\author{
Sergio Rojas Quiñones* \\ Juan Diego Mojica Restrepo**
}

El nexo de causalidad, entendido como la "necesaria conexión fáctica que debe existir entre la acción humana y el resultado dañoso producido"(Pizarro, 2006, p. 87), es uno de los presupuestos fundamentales para la prosperidad de cualquier pretensión indemnizatoria en el marco de la responsabilidad civil. No en vano, se trata de uno de aquellos elementos que resultan imprescindibles en tratándose de cualquier tradición jurídica, ya sea en el derecho de daños continental (civil law) o en el anglosajón (common law). ${ }^{1}$

* Abogado de la Pontificia Universidad Javeriana; magíster en Derecho de Daños de la Universidad de Girona (España). Miembro activo del Instituto Colombiano de Responsabilidad Civil y del Estado, del Centro de Estudios de Derecho Privado de la Pontificia Universidad Javeriana e investigador del Grupo de Investigación en Derecho Privado; profesor de la cátedra de Responsabilidad Civil de la misma universidad, de Obligaciones en la Universidad de los Andes y de varios programas de posgrado; asociado de la firma Salazar, Pardo \&Jaramillo Abogados. Ha escrito varios textos académicos relacionados con la responsabilidad civil y el derecho de obligaciones.Correo electrónico: srojas@spjlaw.com

** Estudiante de X semestre de la Pontificia Universidad Javeriana. Director de la revista Universitas Estudiantes; miembro del Semillero de Investigación en Derecho Procesal y del Grupo de Investigación en Derecho Civil en las líneas de investigación en Responsabilidad Civil y Contratos de la Universidad Javeriana. Actualmente está vinculado a Salazar, Pardo \& Jaramillo Abogados. Correo electrónico: judimore87@hotmail.com

${ }_{1}^{1}$ Sobre la similitud en la concepción de la causalidad en el common law y el civil law, Eric Engle expone: "Causation is one of the most complex and unclear aspects of tort law. However, common law and civil law reach surprisingly similar legal solutions about the problem of causation despite the fact that the problema of causation in tort law is, at least in theory, factually indeterminate. Legal convergence in tort law was not merely a pragmatic result of economic facts. It was also implicit in common philosophical presuppositions about causality in national law which influenced tort law in both common law and civil law countries and provided the basic 
Colombia no es la excepción a este aserto. El artículo 2341 del Código Civil indica que "[e]l que ha cometido un delito o culpa, que ha inferido daño a otro, es obligado a la indemnización (...)", de donde se colige entonces que solo a quien le resulte imputable la conducta, a título de acción u omisión, le es atribuible la responsabilidad. Así, quienes no son los detonantes causales del resultado no pueden, en modo alguno, ser obligados a indemnizar o, puesto en otros términos, solo quien ha dado lugar al daño - lo ha causado - tiene legitimación pasiva para ser condenado.

Lo anterior no es sino lógica consecuencia de la estructura misma de la responsabilidad y, más allá de eso, de la filosofía moral que subyace a ella. Ciertamente, la consecuencia natural de la libertad que se le reconoce a todo individuo por el solo hecho de ser persona supone, entre otras, que ese individuo se apropie de sus acciones y de los resultados a que estas conducen. En ese orden de ideas, solo podemos reconocer la idea de libertad si entendemos que, como agentes, somos el dominus de lo que hacemos o dejamos de hacer y, de contera, somos responsables por sus resultados. Este es el presupuesto de la teoría de la agencia que, se itera, nos reconoce como libres pero, a su turno, como responsables. Naturalmente esta idea tiene una contracara que también debe ser clara: así como somos dueños - y, por ello, responsables - de nuestras acciones, no lo somos de las acciones de otros; lo que haga o deje de hacer un tercero no compromete nuestra responsabilidad por la sencilla razón de que no somos dueños de tales acciones; ese es el presupuesto fundamental de la libertad.

Pues bien, todo ello se hace patente en la exigencia del vínculo de causalidad. La mejor expresión de que solo somos responsables por los resultados que causemos es la causalidad que, en ese orden de ideas, se erige como la versión jurídica del principio moral de la agencia, en virtud del cual, como somos dueños de nuestras propias acciones, somos también dueños de sus resultados. Allí estriba la importancia de la causalidad. Con todo, si bien resulta indiscutible que solo quien con su actuar ha causado un daño deberá repararlo,

superstructural framework for legal convergence" (Engle, 2009, p. 3). Sobre la causalidad en el common law, el profesor norteamericano Larry Alexander afirma: "[T] he fact that a particular defendant's conduct was a 'but for' cause of an injury to a particular plaintiff, which fact is a necessary condition for the plaintiffs recovering corrective damages from the defendant, is the fundamental building block of all tort law. Regardless of what other conditions, if any, tort law imposes as necessary for plaintiff's recovering from the defendant - proximate causation, foreseeability, negligence or recklessness or intent, design defect- - 'but for' causal link between the plaintiffs injury and the defendant's conduct is essential. No causation, no tort" (Alexander, 1987, p. 1). 
esta claridad se pierde en una nube de complejidad e indeterminación al momento de establecer, en concreto, el vínculo causal entre el perjuicio irrogado y el actuar de quien es sindicado como agente dañador.

$\mathrm{Al}$ respecto señala Obdulio Velásquez que

el sentido común se niega a admitir que la existencia de un daño sea soportada por quien no ha influido en la realización del mismo. Entonces se necesita una relación causa-efecto entre el acto humano y el daño que se produce, es decir, la causación del daño por el agente dañino es necesaria para que se configure responsabilidad civil, además del daño y la culpa. En ocasiones, la identificación de la causa no ofrece especiales dificultades para el operador del derecho, pero en otras, especialmente si concurren muchos factores que podrían ser causa de ese resultado dañoso, el determinar a la luz del derecho cuál o cuáles factores deben recibir la categoría de causa ofrece serias dificultades conceptuales y prácticas (2009, p. 461).

Estas dificultades, como es de sobra conocido, tienen su punto de partida por fuera del derecho, en la medida en que se remiten al mundo de la física y de la filosofía. Es así como tradicionalmente se ha identificado que la cuestión del nexo causal ofrece dificultades desde la perspectiva conceptual (¿qué es la relación causa-efecto?), metafísica (¿qué es lo que ocurre en el mundo cuando aludimos a una conexión causal?) y epistemológica (¿cómo conocemos la causalidad?), lo que ha conducido a que, desde el empirismo, se acuñen las más diversas teorías para explicar este fenómeno, cada una situada en consideraciones diferentes y en el replanteamiento de los postulados de su predecesora: las teorías regularistas, las de los juicios contrafácticos, las probabilísticas y las de los procesos fijos, por mencionar solamente los géneros más destacados.

En el derecho, esta dificultad también se ha hecho patente, tanto en la esfera penal como en la civil. En lo que concierne a esta última, el derecho de daños ha debido enfrentarse a las conocidas problemáticas de la sobredeterminación causal, la incertidumbre en el nexo (causalidad alternativa con incertidumbre en el agente, causalidad alternativa con incertidumbre en la correspondencia agente-víctima, víctimas no identificadas e incremento de riesgo, por citar sus expresiones más representativas), la causa potencial, la causalidad alternativa hipotética, entre otras más. Como es obvio, las soluciones han sido disímiles y se 
han debatido entre los extremos de las reglas de preponderancia ('more probable than not' o reglas de 'todo o nada') y proporcionalidad o probabilidad, como se observa en los Principios de Derecho Europeo de la Responsabilidad Civil. ${ }^{2}$ Esto ha llevado entonces a que la causalidad se erija como uno de los elementos de más difícil estudio al momento de adelantar un juicio de responsabilidad civil. ${ }^{3}$ Como lo indicara recientemente un reconocido autor:

\footnotetext{
2 En relación con las nuevas tendencias en materia de causalidad, no debemos registrar el pronunciamiento del 16 de mayo de 2011, en el que la Sala de Casación Civil de la Corte Suprema de Justicia indicó que “... admitida la variedad extremada de situaciones, a las concepciones de la prueba del nexo causal (causalidad eficiente, adecuada, equivalencia de condiciones, etc.) y mecanismos tradicionales de facilitación (prueba prima facie, Anscheinsbeweis der Kausalität, res ipsa loquitur, id quod plerumque accidit, causalité virtuelle, inversión de la carga probatoria, presunciones hominis), el derecho comparado plantea soluciones disímiles de bastante envergadura, ad exemplum, los juicios de probabilidad parcial (causalité partielle o causalitá raziale), posible (mögliche Kausalität Prinzip), probabilística (probabilistic causation approach, causalitá probabilística), conexión probable, predicibilidad o proporcional (proportional causation approach), la causalidad disyuntiva, alternativa, anónima, sospechada, colectiva o conectada, la 'responsabilidad colectiva' (Ley 25675, Argentina) o la 'responsabilidad anónima', dándose un grupo presunto de responsables, tomándolos in solidum a todos. En sentido análogo, algunas legislaciones disciplinan presunciones de causalidad cuando de las circunstancias fácticas del caso concreto un comportamiento es idóneo para causar el daño, se presume efectivamente causado por éste sin requerir la prueba cierta del nexo, verbi gratia, la idoneidad específica de una planta para producir el daño será apreciada conforme a los detalles concretos de su ejercicio, operaciones, equipo utilizado, naturaleza y concentración de las sustancias liberadas en el medio ambiente, las condiciones atmosféricas, la hora y lugar del daño, y bajo cualquier otra circunstancia que, en su contexto fáctico, pueda proporcionar evidencia a favor o en contra de su ocurrencia, salvo si obtenidas todas las autorizaciones para funcionar, no se encuentra ninguna anomalía en su ejercicio (art. 305 del Dlgs. 152/2006, Italia). E1 §6 de la Ley alemana del Medio Ambiente (UmweltHG, de 10 de diciembre de 1990) previene la presunción de causalidad cuando la instalación se considera 'apropiada'o 'intrínsecamente adecuada' para generar el daño, en cuyo caso probada la adecuación, compete al presunto autor acreditar que no es su causa o enervar la presunción demostrando su idónea utilización, ausencia de anomalías en su funcionamiento y el cumplimiento de los 'deberes de utilización' $(2, \S 6)$ u otra circunstancia 'apropiada' (§7), y la jurisprudencia americana aplica además de las reglas but for test (condicio sine qua non), las relativas al factor sustancial conforme a un test de probabilidad, 'balance de probabilidades' (balance of probabilities), precisándose en el marco de circunstancias fácticas la probable causación del daño o su no ocurrencia (more probable than not, more likely than not), acorde a la preponderancia del hecho (preponderance of the evidence), el criterio more probable than not, 'juicio dentro del juicio' (trial within the trial; procès-dans-le-procès) o juicio probabilístico fundado en un conjunto serial de casos tomando las actividades generales y las particulares a apreciar, así como la causalidad alternativa..." (Corte Suprema de Justicia, sentencia del 16 de mayo de 2011) (Díez-Picazo, 1989, p. 338).

${ }^{3}$ Con relación a esta dificultad, se ha dicho en el derecho francés: "La causalité est une notion qui fait presque consensus au sien de la doctrine français... sur sa difficulté: "la notion de causalitéest une redoutable sirène: elle égare volontiers ceux que sa subtilité séduit et qui cherchent à la pénétrer jusque dans ses mystères intimes'. Il est certain que 'l'analyse de la causalité n'a guère tenté les auteurs français, pénétrés qu'ils étaient de la vanité de leurs recherches face au pragmatisme de la jurisprudence', et l'on déplore ses 'affres', ou ses 'arcanes'. La causalité serait 'le problème le plus complexe de la responsabilité civile', un 'redoutable mystère', une notion 'd'une extrême
} 
$[\mathrm{L}]$ os hechos que provocan una modificación en el mundo externo no siempre se presentan con claridad meridiana que permita dilucidar fácilmente cuál es la causa jurídica de un determinado efecto dañoso. De manera frecuente, denotan complejidad, motivada por la concurrencia de múltiples circunstancias distintas que actúan como condición del resultado dañoso. Determinar cuál de esas condiciones es la causa del resultado dañoso producido constituye, de tal modo, una cuestión vital y compleja, que ha desvelado no sólo a juristas sino también a filósofos (Pizarro, 2006, p. 92).

No es gratuita entonces la preocupación que asalta a los estudiosos del derecho de daños ante la incertidumbre existente frente a este presupuesto fundamental de la responsabilidad civil. ${ }^{4}$ A las complejidades físicas y naturalistas, se suma el hecho de que sin una causalidad clara no es posible la imputación del daño a su autor, pues no se podrá develar la relación causaefecto que da el lugar de deudor de la obligación indemnizatoria al agente dañador. Tampoco se alcanzará a delimitar el alcance de la indemnización; en otras palabras, se desconocerán cuáles son los perjuicios que ciertamente se han derivado de la conducta dañosa.

Pues bien, para intentar facilitar esta tarea de averiguar quién es el obligado a reparar el daño sufrido por cierta persona, se han desarrollado una variedad de teorías jurídicas. La teoría de la equivalencia de las condiciones, la teoría de la causa próxima, la teoría de la causa eficiente, la teoría de la causalidad adecuada y, más recientemente, la teoría de la imputación objetiva, se han encargado, con diferentes criterios, de permitir la determinación del agente

difficultê', 'toujours irritante', un problème 'insoluble'; 'l'un des champs de discussion les plus difficiles et aussi les plus confus de la doctrine', et 'l'une des questions les plus insaisissables de notre droit'; sa théorisation serait une 'recherche absolument vaine" (Quézel-Ambrunaz, 2010).

${ }^{4}$ Con todo, valga resaltar, como lo hace Pizarro, que "el papel protagónico de la relación de causalidad en el derecho de daños se ha agigantado en las últimas décadas, luego de haber permanecido ignorado o relegado a un plano secundario por la doctrina civilista que, a lo largo de un prolongado período de la historia, resolvió '[...] las dudas acerca del alcance del nexo causatorio [...] acudiendo en situaciones concretas a pautas empíricas [...]', impregnadas de una elevada dosis de intuición y del particular sentimiento de justicia de cada magistrado. Recién a mediados del siglo pasado, el hombre de derecho logró formular la teoría de la relación de causalidad sobre bases verdaderamente científicas, dotándolas de autonomía conceptual y funcional, y la independizó de los demás presupuestos de la obligación de resarcir" (2000, p. 255). 
generador del daño y la delimitación de cuáles son los daños conectados con su actuar y, de contera, el alcance de su responsabilidad.

En Colombia, la jurisprudencia de la Corte Suprema de Justicia en su Sala de Casación Civil ha acogido la teoría de la causalidad adecuada como herramienta para señalar cuándo una actuación ha sido la causa de un daño y, a partir de ello, condenar a su autor a reparar el perjuicio irrogado. Por esta razón, el presente estudio pretende exponer las limitaciones que se le han atribuido a la teoría de la causalidad adecuada, que, por fundamentarse en parámetros abstractos como las máximas de la experiencia, el sentido común y la previsibilidad, pueden llegar a enervar la indemnización de ciertos daños que, de acuerdo con la justicia, deberían indemnizarse.

Se demostrará que la inexistencia de una distinción entre causalidad de hecho y causalidad de derecho — $\mathrm{o}$, más propiamente, entre causalidad e imputación objetiva - en el sistema jurídico nacional ha llevado a que el criterio de la adecuación (y, de contera, el parámetro del observador óptimo y la prognosis póstuma) sea adoptado como una teoría de la causalidad fáctica y no de la imputación propiamente dicha, que es como, en principio, debería figurar. Ello ha acarreado una serie de inconvenientes, por ejemplo, por solapamiento de las categorías y por reducción al absurdo en lo tocante con la causalidad fáctica.

Es por ello por lo que como propuesta se presentará una teoría que propende por la diferenciación entre una causalidad de hecho y una causalidad de derecho, en aras de determinar acertadamente cuándo se configura la relación causal. Con esta distinción se intenta superar los problemas achacados a la causalidad adecuada, para prevenir los resultados contraintuitivos que se presentan con su aplicación. Para la primera clase de causalidad propuesta, la causalidad de hecho, se recurrirá al juicio contrafáctico que proporciona la conditio sine qua non; este permitirá afirmar cuándo existe relación causa-efecto de un hecho frente a un daño, desde una perspectiva física o meramente naturalística. En cuanto a la segunda, la causalidad de derecho, se retomará el juicio de previsibilidad del que echa mano la teoría de la causalidad adecuada para lograr la imputación objetiva de un perjuicio a un agente.

Como es obvio, a esta teoría, como a todas aquellas que se encuentran en proceso de perfeccionamiento, se le ha identificado un conjunto de dificultades, como lo son la sobredeterminación y la indeterminación causal. Así, en el presente escrito se expondrán también las fórmulas que se consideran más apropiadas para dar solución a los problemas mencionados, encontrando en 
las reglas de proporcionalidad o probabilidad las construcciones con mayor solidez a la hora de afrontar las situaciones inciertas puestas de presente.

Finalmente, se evidenciará cómo la tesitura propuesta muestra sus mayores bondades en ámbitos en que la causalidad es sumamente controversial, como sucede, por ejemplo, en la esfera de la responsabilidad ambiental. Ciertamente, uno de los escenarios en donde se torna más dificultosa la determinación de la relación causa-efecto es el que tiene que ver con los daños irrogados al ambiente, comoquiera que allí son más que usuales las hipótesis de causalidad incierta, concurrencia de agentes y sobredeterminación. Por todo ello, se ha decidido aterrizar la propuesta planteada en el campo específico de la responsabilidad civil ambiental, que es uno de aquellos en donde esta puede reflejar sus mayores aciertos.

En cualquier caso, no sobra mencionar que no solo en el último acápite se aplica la cuestión al tema de la responsabilidad ambiental. En general, todas las reflexiones que se proponen a lo largo del escrito son especialmente aplicables a este particular escenario, comoquiera que en él se hacen patentes muchos de los grandes problemas de la causalidad contemporánea. En efecto, son de sobra conocidos, en la esfera ambiental, los problemas derivados de la concurrencia de contaminadores, de daños en masa, de daños anónimos, de contribuciones causales, entre otros; así las cosas, los problemas propios de la relación de la causalidad se hacen especialmente patentes en la esfera ambiental, en donde la incertidumbre es cuestión de todos los días. De ahí entonces que este estudio, en su integridad, tenga relevancia al análisis del problema causal en el escenario de la responsabilidad civil ambiental, en los términos ya señalados.

Con esto se intenta exponer un sistema de adecuación casual en materia de responsabilidad civil que ofrezca el remedio más idóneo a las dificultades que hoy en día se presentan en esta materia, abriendo el debate, a partir de la crítica positiva, a la reformulación de las teorías actualmente empleadas.

\subsection{El problema general de la relación de causalidad y su solución}

\subsubsection{Causalidad en materia de responsabilidad civil. Una aproximación a las diferentes teorías \\ El nexo de causalidad en materia de derecho de daños toma su definición de otras ciencias. En efecto, diferentes planteamientos filosóficos, físicos y}


científicos proporcionan las bases para la construcción del concepto causal en la esfera jurídica. ${ }^{5} \mathrm{El}$ primer autor reconocido en adelantar un estudio sistemático sobre esta materia fue Aristóteles; el filósofo griego propuso una tipología causal formada por cuatro tipos de causas, a las cuales denominó causa formal, causa material, causa eficiente y causa final. ${ }^{6}$ De todas estas categorías, la causa eficiente es la que nos permite identificar la existencia de una relación causa-efecto entre la actuación de un sujeto y un daño, pues es esta la que predica que "es causa lo que da comienzo al cambio o a la quietud, por ejemplo, el autor de una decisión es la causa de ella, el padre es causa del hijo y, en general, lo que produce el cambio es causa de éste" (Abbagnano, 1992, pp. 136-138). Esta concepción ha permeado al derecho. Así, por ejemplo, el profesor Luis Díez-Picazo, al comentar la definición de causa presentada en la Enciclopedia de Diderot y D’Alembert, expresa: "[C]ausa es todo aquello en virtud de cuya eficacia una cosa es; y efecto todo aquello que es en virtud de la eficacia de una causa” (Díez-Picazo, 2007, p.359), ${ }^{7}$ de donde entonces se colige que la consabida causalidad no es más que

${ }^{5} \mathrm{Al}$ respecto se ha dicho que "mientras la causalidad genera una serie de preguntas interesantes en la filosofía - p. ej. la crítica de David Hume (1711-1776) hacia el entendimiento convencional de la necesidad causal一, su discusión dentro de la filosofía del derecho se relaciona normalmente con la manera en que dicho concepto ha sido reformulado por la doctrina jurídica, a fin de reflejar ideas e intuiciones relativas a la responsabilidad moral y a las políticas públicas. En el derecho, al igual que en la filosofía moral, el tema de la 'causalidad' está estrechamente ligado con la atribución de responsabilidad o culpa derivada de un incidente o suceso, aunque en un sentido más amplio o empírico de 'causalidad' el incidente o suceso haya sido el producto de un número de acciones y circunstancias más extensas, y quizá infinitas" (Bix, 2009, p. 74). Así mismo, el profesor Díez-Picazo reconoce: "Aunque la utilización del concepto de causa por los juristas haya tenido su origen en consideraciones de orden filosófico, al trasladarlo después a un lenguaje usual, es muy probable que la apreciación causal en materia jurídica se comenzara haciendo de una forma artesanal, de acuerdo con las experiencias de que se disponía" (Díez-Picazo, 2007, p. 359).

${ }^{6}$ Sobre este punto, Goldenberg hace el siguiente aporte: "Es, sin embargo, con Aristóteles que puede situarse el inicio del llamada 'causalismo científico'. El Estagirita requiere el concurso de cuatro causas para la producción de cualquier resultado. Todo efecto, de acuerdo con su pensamiento, ha de ser producido por algo o por alguien (causa eficiente), para algo (causa final), de algo (causa material) y con introducción de algo (causa formal). Se distinguen, de este modo, cuatro géneros de causa: efficiens, finalis, materialis y formalis. La causa material y la formal con causas del ser; la eficiente y la final, causas del devenir" (Goldenberg, 1984, p. 5). Cfr. Engle (2009, p. 3).

${ }^{7}$ Nicola Abbagnano, en su diccionario de filosofía, comenta sobre la causalidad que "en su significado más general, la relación entre dos cosas, en virtud de la cual la segunda es unívocamente previsible a partir de la primera. Históricamente esta noción ha adquirido dos formas fundamentales: 1) la forma de una relación racional, por la cual la causa es la razón de su efecto que, por lo tanto, es deducible de ella. Esta concepción describe a menudo la acción de la causa como una fuerza que genera o produce necesariamente el efecto;2) la forma de una relación empirica o temporal, por la cual el efecto no es deducible de la causa, pero es previsible 
"el enlace material entre un hecho antecedente y un resultado (daño), conocido en la doctrina como 'imputabilidad o atribuibilidad objetiva', 'imputatio facti o vínculo material" (Goldenberg, 1984, p. 2), que, por lo demás, en su condición de elemento axiológico de la responsabilidad civil, tiene la función de dar respuesta a dos preguntas estructurales: ¿quién debe responder? y ¿hasta dónde debe responder?8

Ya lo señalaba Díez-Picazo, para quien:

\begin{abstract}
[E]1 concepto de causa y el de causalidad se utilizan en materia de responsabilidad civil, para tratar, básicamente, de dar respuesta a dos tipos de problemas: el primero es encontrar alguna razón por la cual el daño puede ligarse con una determinada persona, de manera que se pongan a cargo de ésta, haciéndola responsable, las consecuencias indemnizatorias, para lo cual se utiliza el concepto de causa en el
\end{abstract}

a partir de ella, por la constancia y uniformidad de la relación de sucesión. Esta concepción elimina de la relación causal la idea de fuerza. A ambas formas les es común la noción de la previsibilidad unívoca, esto es, infalible, del efecto, a partir de la causa y por lo tanto de la necesidad de la relación causal” (1987,p. 152).

${ }^{8}$ Sobre este punto, De Cupis expone: "No menor importancia reviste el establecer la magnitud, o sea, la dimensión o montante, el quantum del daño al que el ordenamiento jurídico atribuye valor de hecho jurídico, uniéndole una reacción propia. Establecida la transmisión de la carga del daño de un sujeto a otro, importa precisar, además, cuánto daño deba experimentar tal transmutación y cuánto daño deba ser eventualmente soportado por el que lo ha sufrido. La determinación del quantum respondeatur tiene, precisamente, tanta importancia como la del determinar al an respondeatur, porque, de poco serviría tener derecho al resarcimiento si fuese mínima la entidad del daño a resarcir. En consecuencia, importa enormemente precisar los límites cuantitativos dentro de los que el daño asume sentido jurídico [...] El contenido jurídico del daño, está ante todo, en función de la relación de causalidad entre el hecho productor del daño y el daño, es decir, que para fijar el montante del daño que debe reprimirse jurídicamente, se requiere, en primer lugar, establecer los límites dentro de los que el daño pueda considerarse causado por un hecho humano provisto de los atributos exigidos por la ley con fines de responsabilidad" (De Cupis, 1970, pp. 245-246). Sobre el particular, Prevot comenta: "La causalidad cumple en el derecho de la responsabilidad civil dos funciones: 1) una relativa a la imputación del hecho dañoso a su autor $\mathrm{o}$, si se prefiere, tendiente a la individualización del responsable, denominada por buena parte de la doctrina autoral italiana como 'causalidad material'; y 2) otra, consistente en determinar el contenido de la obligación resarcitoria, conocida como 'causalidad jurídica'. Una cosa es, entonces, emplear la causalidad a los fines de imputar el evento lesivo a un sujeto (causalidad como requisito autónomo de la responsabilidad), y otra muy distinta es utilizar la causalidad para determinar la medida de la reparación (causalidad como complemento). En el primer caso, se responde al interrogante ¿quién causó el daño? (etapa del an respondeatur). Mientras que en el segundo, se responde a la pregunta ¿cuánto debe pagar el responsable? (etapa del quantum respondeatur). Esta doble función que cumple la causalidad en el ámbito de la responsabilidad civil, junto a las diversas formas que forzosamente adquiere la misma, según el ámbito o fattispecie en que opere, imposibilitan todo intento de reconstrucción unitaria”(2010, p. 146). 
artículo 1902 cc [análogo del artículo 2341 de la codificación colombiana] al imponer el deber de indemnizar a 'el que causa daño a otro'; en segundo lugar, se trata de relacionar, a la inversa de lo que hacíamos anteriormente, al daño con la persona, pues el precepto, remarcando el uso de la palabra causa, dice que se indemniza 'el daño causado' (2007, p. 235). ${ }^{9}$

En similar sentido, Ramón Daniel Pizarro afirma que la causalidad brinda "los parámetros objetivos indispensables para calibrar la extensión del resarcimiento, mediante un régimen predeterminado de imputación de consecuencias. A través de ella se determina hasta dónde el sistema vigente quiere que el autor material responda por sus actos evitándose la elongación excesiva del perjuicio y el enriquecimiento consiguiente del damnificado" (Pizarro, 2006, p. 89). ${ }^{10}$

De esta forma, se tiene que la causalidad permite al demandante determinar contra quién debe dirigir su pretensión indemnizatoria y cuáles son

\footnotetext{
${ }^{9}$ En igual sentido, señala López Mesa: "Para que una persona pueda ser tenida como civilmente responsable por un acto ilícito dañoso, resulta imprescindible que el daño pueda ser objetivamente atribuido a la acción u omisión de un hombre o al hecho de una cosa —imputatio facti o relación de causalidad-. En palabras del profesor Brun, 'responsabilidad civil y causalidad son consustanciales" (Trigo Represas y López Mesa, 2011, p. 360). Para Le Tourneau, "racionalmente la responsabilidad civil supone un nexo de causa a efecto entre el perjuicio y el hecho dañino. Este último debe haber sido causa generadora del daño, así como la cosa debe haber desempeñado un papel activo en la producción del daño. Los términos de los artículos 1382 y siguientes justifican este principio: todos exigen que el hecho, la cosa, el animal o el edificio causen el daño. Solo el perjuicio directo podrá ser reparado, porque solo él está ligado por ese nexo de causa a efecto al acto imputado al responsable, el hecho generador" (2010, p. 78). En el ámbito colombiano, Pérez Vives señala: "Para que surja la obligación de reparar un daño es preciso que entre éste y la culpa exista un vínculo que permita afirmar que el primero es efecto de la segunda. En otras palabras, que la culpa haya causado el perjuicio" (1992, p. 327). De igual manera, el profesor Arturo Solarte indica: "Para que se pueda reclamar la reparación del daño antijurídico debe existir una relación de causalidad entre el hecho que lo ha provocado y la conducta de quien se dice fue su autor, sea que ésta haya consistido en una acción o, simplemente, en una omisión" (2004, p. 711).

${ }^{10}$ En otro de sus escritos, dice el mismo autor que "dentro del ámbito de la responsabilidad civil, la relación de causalidad asume una doble función, de singular importancia: a) permite determinar, con rigor científico, cuándo un resultado dañoso es material u objetivamente atribuible a la acción del sujeto determinado; b) brinda, al mismo tiempo, los parámetros objetivos indispensables para calibrar la extensión del resarcimiento, mediante un régimen predeterminado de imputación de consecuencias. Éste es uno de los grandes pilares sobre los que se edifica el moderno derecho de daños, que debe orientar sus esfuerzos hacia una justa e integral reparación de todo detrimento injustamente causado" (Pizarro, 2000, pp. 255-256).
} 
los daños que tiene derecho a que le sean reparados por ese agente dañador. Así mismo, la comprobación de la existencia de un nexo de causal entre la actuación de un sujeto y un menoscabo injustificado en los derechos de una persona permite al juzgador, a la hora de un juicio de responsabilidad civil, imponer la condena única y exclusivamente al causante del daño y obligarlo a resarcir solamente los perjuicios que ocasionó con su conducta.

Finalmente, desde la perspectiva del acusado de haber irrogado un daño, la causalidad le permite ejercer su defensa para que ante la ausencia de esta fracase la pretensión indemnizatoria dirigida en su contra. ${ }^{11}$ De allí se colige también que la causa supone un elemento moralizador: permite hacer patente una exigencia de justicia correctiva en la responsabilidad civil, comoquiera que impone la obligación de indemnizar solamente a quien ha dado lugar a la interacción injusta, del modo que lo sugieren las concepciones contemporáneas de esta forma de justicia. Puesto en otros términos, la causalidad evita que el débito indemnizatorio se disperse en cabeza de cualquier sujeto y lo concentra en cabeza del agente dañador, con lo que cristaliza una exigencia de justicia —y, más específicamente, de justicia correctiva — en la responsabilidad.

El inconveniente, con todo, es que, a la utilidad e importancia práctica de la causalidad, se suma una dificultad ostensible en su análisis y determinación.

\footnotetext{
${ }^{11} \mathrm{Al}$ respecto, el maestro Fernando Hinestrosa explica que "en presencia de un quebranto patrimonial o moral salta a la vista la necesidad de buscar su origen, indagar por el responsable. Si se trata de un daño que la propia víctima maliciosa o descuidadamente se ocasionó, mal podría ella achacarlo a persona distinta, o como se diría en lenguaje familiar, 'buscar el ahogado río arriba'. Si el perjuicio lo causó persona distinta del demando y por la que no está llamado él a responder, a ese tercero deberá acudir la víctima y no a quien nada tiene que ver en el asunto. Por último, si la ocurrencia provino de fuerzas naturales o sociales anónimas e irresistibles, la víctima habrá de padecer su mala suerte sin posibilidad de descargar su quebranto sobre persona determinada" (1961, p. 358). De esta forma, cuando existe una causa extraña, sea esta por la intervención de un tercero (hecho de un tercero), por la propia aportación de la víctima en la producción del daño (hecho de la víctima) o por una causa ajena que revista las características del caso fortuito o fuerza mayor, que dependiendo de su magnitud pueden aminorar o suprimir el vínculo causal de la conducta del agente señalado como dañador con el perjuicio. Para el caso colombiano,Juan Pablo Cárdenas Mejía expone: "El Código Civil colombiano no consagra expresamente la causa extraña como factor de exoneración de responsabilidad, sino que se refiere a la fuerza mayor y al caso fortuito. Sin embargo, la jurisprudencia y doctrina se refieren a la causa extraña como eximente de responsabilidad. Históricamente la distinción entre causa extraña y fuerza mayor surge de la redacción del Código Civil francés que hace referencia a dichos conceptos. Aunque la noción de causa extraña se basa en la redacción de dicho código, ha sido recogida por nuestra doctrina en la medida en que agrupa aquellos elementos que exoneran de responsabilidad y que son ajenos al deudor o a la persona a la que se le pretende imputar la responsabilidad. Tradicionalmente se han señalado como casos de causa extraña la fuerza mayor o el caso fortuito, el hecho de un tercero o el hecho de la víctima" (2010, p. 349). Sobre el mismo tema, se pueden consultar: Pizarro (2000, pp. 255 y ss.) y Medina Alcoz (2003).
} 
Ciertamente, como se ha expuesto a lo largo del texto, por sencillo que pareciera, en principio, adelantar el análisis de causalidad, lo cierto es que las ciencias jurídicas se encuentran aún lejos de encontrar una teoría que responda satisfactoriamente a tales interrogantes. ${ }^{12}$ Como lo resalta el profesor Jorge Santos Ballesteros, "a pesar de su presencia ineludible, sin embargo, y no obstante constituir esa relación el enlace entre el hecho causante del ilícito y el detrimento de la reparación, no siempre su configuración jurídica ha obedecido a criterios uniformes o patrones definidos, al contrario de lo sucedido con los otros dos factores integrantes de la responsabilidad civil, es decir, la culpa y el daño"(2013, p. 376). Para dar una idea del laberinto que representa desentrañar el nexo de causalidad en materia de responsabilidad civil, resalta ilustrativo un difundido ejemplo doctrinal. Supóngase la siguiente situación:

Leo en el diario $A B C$ : "Un perro cae al vacío y provoca varias muertes consecutivas. Una cadena de sucesos trágicos se sucedió en el barrio bonaerense de Caballito a partir del momento en que un perro cayó accidentalmente desde un decimotercer piso. 'Cachi', que así se llamaba el animal, fue a golpear en la cabeza de Marta Fortunata, de setenta y cinco años, que caminaba despreocupada por el lugar. Como consecuencia del impacto, la anciana murió de forma instantánea. Seguidamente, una rueda de curiosos se comenzó a formar en torno al cadáver. El corro desbordó pronto la acera y comenzó a ganar parte a la calzada, donde el tráfico se desarrollaba a gran velocidad. En ese

\footnotetext{
${ }^{12}$ Con claridad expone sobre esta problemática Tamayo Jaramillo, quien afirma: "La doctrina pareciera resignarse ante la imposibilidad de dilucidar con claridad el problema del nexo causal y encontrar una teoría que lo solucione satisfactoriamente. Al respecto, Geneviève Viney expresa: 'Numerosos juristas de todos los países han puesto seriamente en duda la utilidad de las tentativas de solución científica del nexo de causalidad'. En Francia, Ripert, por ejemplo, ha tomado posición muy clara en favor de una actitud puramente pragmática al respecto, y en ese sentido expresa: 'La jurisprudencia haría bien si rechaza el entregarse al análisis de causalidad porque ésta ha suscitado brillantes estudios doctrinales que no han aportado ninguna solución a este problema general que es tal vez insoluble'. Y los señores Mazeaud, de su lado, después de haber recordado que la causalidad debe ser cierta, lo que implica, dicen ellos, que el daño es la consecuencia necesaria del hecho percibido, confiesan que es difícil dar más precisión sobre la noción de daño indirecto y se pliegan a la opinión de Demogue para quien 'se trata de una cuestión de buen sentido más que de ciencia... que ha agotado las paciencias más probas'. Estos autores se limitan a dar ejemplos sin pretender alcanzar una noción general. Boris Starck va más lejos aún, puesto que afirma sobre este punto que 'todo ensayo de razonamiento científico se vuelve ineficaz', lo que parece igualmente ser la opinión de Esmein”(2007, p. 380).
} 
momento, un autobús alcanzó de lleno a Edith Solá, de cuarenta y seis años, quien murió en el lugar después de haber sido arrastrada varios metros por el vehículo. Cuando el estupor de los presentes ante este trágico suceso no había desaparecido, frente al escenario de los hechos, un hombre que no fue identificado sufrió un ataque cardíaco y murió minutos después, en el interior de la ambulancia que lo trasladaba a un hospital" (Yzquierdo, 2001, p. 1987).

Ante esta cadena de eventos infortunados aflora la duda sobre la causa que los ha generado y quién será el llamado a responder. Dependiendo de la teoría jurídica de determinación causal que se adopte, ya sea la teoría de la equivalencia de las condiciones, la teoría de la causa próxima, la teoría de la causa eficiente, la teoría de la causa adecuada, o se opte por la teoría de la imputación objetiva, la decisión sobre quién deberá soportar la reparación del perjuicio podrá variar, como se pasa a ver.

Para determinar la causa de un daño, la teoría de la equivalencia de las condiciones utiliza un juicio contrafáctico, en el cual se parte de la supresión de los eventos considerados como posibles causas del perjuicio, para evaluar si a pesar de la falta de alguno de estos el daño subsiste. Si la respuesta al realizar dicha operación es negativa (la consecuencia no desaparece a pesar de la omisión de la posible causa), se descarta dicha posible causa; por el contrario, si la respuesta es positiva (la consecuencia desaparece por la omisión de la posible causa), se tiene a este por causa del daño y, además, se le tiene en iguales condiciones que todos los demás que cumplan con el test, considerándolas a todas conditio sine qua non del perjuicio irrogado, por cuanto "faltando cualquiera de ellos, el daño no se habría producido" (Le Tourneau, 2010, p. 79). ${ }^{13}$ Es, en esencia, la estructura del juicio contrafáctico típico.

Para mayor claridad, se examina el caso expuesto anteriormente a luz de la teoría presentada, a fin de ejemplificar lo que sería el resultado de un juicio de causalidad bajo esta concepción. Ante la muerte de la señora, es evidente que, si se suprime la caída del perro desde lo alto, se arriba a la conclusión de

\footnotetext{
${ }^{13}$ Sobre la teoría de la equivalencia de las condiciones, Díez-Picazo explica: "Cuando un resultado aparece tras un conjunto de condiciones, el método experimental exige suprimir mental o empíricamente cada una de ellas. En este sentido, causa es la condición sine qua non del daño, es decir, aquel de los elementos o las condiciones que, si hubieran faltado, el resultado dañoso no se hubiera producido. Si se quita la causa, desaparece la consecuencia (sublata causa tollitur efectus)" (2007, p. 360).
} 
que esta es conditio sine qua non de esta eventualidad, comoquiera que, a falta de perro, no habría resultado dañoso.

Pero, de otro lado, si se suprime el hecho de que quien habita en dicho apartamento del decimotercer piso tuviera dicha mascota, lo cierto es que el resultado dañoso tampoco habría ocurrido, lo que haría que el hecho de vivir en ese piso con una mascota se erija también en causa del daño. Más aún, si se realiza el juicio contrafáctico en relación con la existencia de un edificio de dicha altura, la conclusión es que en ausencia de este la muerte no hubiera tenido lugar; el constructor sería entonces también detonante causal del hecho. Se tiene entonces, a partir de la teoría de la equivalencia de las condiciones, que el nexo causal se extiende ad infinitum, pues se equiparan las condiciones para la producción del hecho dañoso a las causas de este, ${ }^{14}$ dando lugar a respuestas inequitativas, ya que expande la órbita de responsabilidad a agentes que, por la lejanía con el hecho dañoso, carecen del vínculo necesario con el daño como para que sean condenados a repararlo, tal como sería el caso del constructor del edificio. ${ }^{15}$

En este punto se asientan las principales críticas que se han esgrimido en contra de esta teoría. Jurídicamente resulta inaceptable expandir ad nauseam la relación causal entre un hecho y un resultado. ${ }^{16}$ Si bien la teoría de la

\footnotetext{
${ }^{14}$ Sobre la diferencia que debe existir entre condiciones y causas de un daño, que no se logra al aplicar la teoría de la equivalencia de las condiciones, Pizarro manifiesta: "La condición es un mero antecedente del resultado que produce. Ordinariamente un efecto es producido por múltiples condiciones, que en conjunto lo provocan. El derecho, como regla general, no atribuye autoría material del daño, ni responsabiliza a un sujeto por el mero hecho de haber puesto una condición, aunque esta pueda ser necesaria para su producción, ya que en caso de no haberse producido, el efecto no se habría desencadenado. Es preciso, para ello, que la condición asuma especial entidad, por ser adecuada para producir ese resultado, en cuyo caso se eleva a la categoría de causa jurídica, generadora del detrimento. Así concebida la cuestión, puede afirmarse que 'si bien la causa es siempre una condición de daño, no toda condición es causa'. Dentro de las muchas condiciones que pueden contribuir a un resultado, encontramos a la ocasión, que favorece o torna viable la actuación de la verdadera causa del daño, pues permite, facilita o potencia su aptitud causal. En principio no se responde por el mero hecho de haber facilitado o provocado la ocasionalidad del daño. Quien invita a un amigo a practicar golf, no responde si en ocasión del juego, éste es lesionado por la pelota lanzada al jugador, o es agredido con motivo de una discusión con otro competidor" (2006, p. 91).

${ }^{15}$ Adicionalmente, el profesor Suescún Melo pone de presente que "se le reprocha su falta de elasticidad, pues exige, en caso de concurrencia de culpas con la víctima, dividir por partes iguales la indemnización, pues recuérdese que esta doctrina considera que todas las causas concurren del mismo modo a la producción del daño, lo que puede estar en oposición con la equidad" (2003, p. 150).

${ }^{16}$ Con todo, hay quienes también critican esta teoría por dejar impune al autor de ciertos daños. Así lo hace Díez-Picazo, para quien "la fórmula de la condición snq [sine qua non] peca también, sigue diciendo Antunes Valera, además de por exceso, por defecto, ya que no comprende dentro del nexo de
} 
equivalencia de las condiciones permite materialmente determinar un vínculo causa-efecto, lo cierto es que lo hace desde un punto de vista material o natural; desde el derecho de daños, no es equitativo el criterio que ella propone para imputar a alguien una condena a reparar los perjuicios sufridos por otra persona. ${ }^{17} \mathrm{Al}$ respecto, Philippe Le Tourneau hace la siguiente reflexión:

\begin{abstract}
Si en otras épocas esta teoría podría permitir una reparación equitativa de los daños, en una economía esencialmente agrícola y artesanal, ya eso no ocurre hoy en día. El progreso técnico, que permite manejar las fuerzas naturales considerables, el desarrollo del maquinismo, las interacciones más frecuentes de las actividades humanas, a veces provocan consecuencias en las que es imposible determinar la parte de cada uno de los intervinientes y cuya amplitud está sin común medida con el papel propio de cada uno de ellos. En fin, para la determinación del nexo de causalidad entre el hecho daniño y sus consecuencias mediatas, necesarias para calificarlas directas, la equivalencia de las condiciones conduce a considerar que permanecen directos y reparables los daños demasiado alejados del hecho generador $y$, para decirlo de
\end{abstract}

causalidad, ciertos daños que sería injusto no pone a cargo del autor de un hecho, como ocurre en la hipótesis que ha sido denominada de causalidad acumulativa o alternativa o en los daños causados por miembros indeterminados de un grupo que efectúa disparos o lanza cócteles molotov, sin que ninguno de ellos, aisladamente considerado, se pueda decir que sin él no hubiera ocurrido el daño sufrido por la víctima, no es causante del daño de manera que habría que entender que no debe ser considerado responsable del daño en el sentido de la sqn del daño verificado. Y, al revés, si, como ocurre en el parágrafo 830 del BGB, se considera que hay autoría múltiple, el daño se está imputando a persona o personas que no lo han causado" (2007, p. 361).

${ }^{17}$ En palabras de De Cupis, "la objeción que se ha formulado a la teoría de la condicio sine qua non es que, mediante ella, el concepto de causa y, por ende, la responsabilidad, se extienden excesivamente. Indudablemente es necesario que el hecho humano sea condición del daño, pero se desplaza el problema a determinar un quid posterior que establezca los límites razonables de la responsabilidad” (1970, p. 256). Con igual criterio señala Atilio Aníbal Alterini, "sutil y vigorosa es la ironía que dedicó Binding a esta teoría, luego de afirmar que según ella todo el mundo es culpable de todo: correspondería castigar como coautor de adulterio no sólo al varón que yace con la mujer casada con otro hombre, sino también al carpintero que hizo la cama" (1992, p. 144). El profesor Santos Ballesteros trae a colación el comentario que sobre el particular hace Pierano, para quien, "aplicada rigurosamente la teoría de la equivalencia de condiciones, tiende a ensanchar en forma exagerada el concepto de causa hasta el punto de hacer de esta noción una idea reñida con el sentido común y con el concepto vulgar de justicia. Suponiendo que en un caso dado concurrieran a producir cierto evento una condición y un caso fortuito, habría que imputar el caso fortuito a quien ha puesto una sola de las condiciones, lo cual es contrario a todo principio ético-jurídico y también el bueno sentido"(2013, p. 393). 
una vez, cuyo nexo con éste es puramente hipotético. El problema mayor de la teoría explota aquí: ésta no permite fijar cómodamente un límite a la extensión de la responsabilidad (2010, p. 81).

En suma, la respuesta que ofrece la equivalencia de las condiciones es una respuesta insuficiente para el derecho. Ciertamente, el criterio de esta teoría, cuando es empleado como único test para determinar la relación de causalidad, no ofrece una respuesta satisfactoria, comoquiera que supone un regreso al infinito en el que la causa de la causa es la causa del mal causado. Esto no quiere decir, en cualquier caso, que sea un criterio erróneo. Para dilucidar la causa desde una perspectiva física o naturalística, la equivalencia de las condiciones o test sine qua non reviste gran utilidad, dado que ofrece una verificación muy certera, al menos en el plano de la acción — comoquiera que en el caso de la omisión ofrece dificultades - Tal vez de lo que requiere es de un complemento jurídico que permita delimitar el regreso al infinito, como se expondrá en un segmento ulterior.

Ahora bien, lo cierto es que, ante la falta de una respuesta satisfactoria desde la teoría de la equivalencia de las condiciones, se han postulado diversas construcciones doctrinarias que intentan presentar diferentes criterios para solucionar la vis expansiva que la conditio sine qua non inconvenientemente proporciona al adelantar el juicio de causalidad en materia de responsabilidad civil.

Así ha surgido, por ejemplo, la teoría de la causa próxima, que es una construcción teórica que, aunque cronológicamente anterior, presenta un criterio que permite escoger, entre las condiciones que producen un daño, a una de ellas como única causa de este. Para la causa próxima únicamente existe nexo de causalidad, a los ojos de la responsabilidad civil, entre el daño y el último hecho que lo precedió. ${ }^{18} \mathrm{El}$ juicio que se realiza cuando se escoge esta teoría para desentrañar la relación de causalidad consiste en seleccionar, entre las múltiples condiciones que dieron lugar al perjuicio, la que cronológicamente lo antecedió —esto es, la inmediatamente anterior al resultado dañoso-,

\footnotetext{
${ }^{18}$ Se ha dicho que, de acuerdo con esta teoría, de origen angloamericano, "la auténtica causa sería la proximate cause y al elegir a esta habría que rechazar todas las que fueran too remote cause. En esta doctrina si existieran condiciones sucesivas que todas ellas son causa de los daños, sólo debería utilizarse la causa más próxima” (Navarro, 2013, p. 191). Sobre la aplicación concreta de esta teoría a un caso concreto, se puede ver: Palsgraf v. Long Island Railroad Co.
} 
evitando de esta manera entrar a hacer juicios ulteriores que den resultados inciertos y que impliquen en términos de Bacon, su autor, una tarea infinita. ${ }^{19}$

Asevera Santos Ballesteros que, "defendida especialmente en Inglaterra, la teoría de la causa inmediata parte de adoptar en la cadena o eslabón de acontecimientos que se entrelazan en la producción de un fenómeno un criterio netamente temporal, para hacer resaltar el que esté más cercano o próximo al resultado" (2013, p. 394).

La solución que a la luz de esta teoría se daría al caso propuesto precedentemente resulta relativamente sencilla: la causa de la muerte de la señora es el golpe que le propinó el perro al caer sobre su humanidad. A eso se reduce el estudio de la causalidad cuando de causa próxima se trata.

Sin embargo, y aunque es evidente lo efectiva que resulta esta teoría para individualizar la causa de un daño, lo cierto es que no se encuentra libre de reparos. Mariano Yzquierdo manifiesta que, "a la dificultad de establecer cuál ha sido la condición última en un suceso, se añade que no siempre el antecedente temporal más próximo en la cadena causal es el determinante. $\mathrm{El}$ concepto de inmediatez ha de tener, por lo tanto, un sentido más lógico que cronológico" (2011, pp. 416-417). ${ }^{20}$

Por estas razones, que evidencian lo inequitativo que resulta en muchos casos la aplicación de esta construcción teórica, es que no logró asentarse ni alcanzar mayor influencia en la doctrina,${ }^{21}$ dando paso a nuevas teorías jurídicas que han logrado mayor aceptación, impregnando la jurisprudencia de diversas latitudes.

19 Sobre la teoría de la causa próxima, afirma el profesor Gerardo Ortiz Gómez que "fue expuesta por Francis Bacon en su obra Maxims of law, publicada en el siglo xvi; es decir, fue planteada con mucha anterioridad a la teoría de la equivalencia de condiciones. La máxima elaborada por Bacon señala: 'Sería para el derecho una tarea infinita juzgar las causas de las causas y las acciones de las acciones de unas sobre las otras: por eso se contenta con la causa inmediata y juzga los actos desde ese punto de vista sin remontarse a un grado superior'; así las cosas solo el hecho más próximo en tiempo al daño es el causante de éste"(2010, p. 322).

${ }^{20}$ Sobre las objeciones formuladas a esta teoría, se puede ver: Trigo Represas y López Mesa (2011, pp. 416-417).

${ }^{21}$ Señala Santos Ballesteros que "la tesis de la causa inmediata o causa próxima no es admitida por la generalidad de la doctrina, por la injusticia evidente que encierra su formulación, dado que de aplicarse, daría lugar a atribuir consecuencias dañosas a actos que en sí mismos no tiene la aptitud para producir un resultado, o no atribuirlas a los que sí la tienen, al faltar la correspondencia necesaria que debe existir entre uno y otro de los extremos de la responsabilidad, pues la disposición cronológica no se corresponde siempre con la causal o lógica que debe presidir este análisis" (2013, p. 396). 
Es el caso, por ejemplo, de la teoría de la causa eficiente, que, como lo dice Jorge Suescún Melo, "ha tenido el favor de un sector importante de la doctrina y de la jurisprudencia nacionales recientes" (2003, p. 161). Para esta formulación doctrinaria "no interesa ya el acontecimiento que ha precedido inmediatamente al daño, sino que hay que establecer su condición causal según el grado de eficiencia en el resultado (causa efficiens), en oposición al principio de indiferencia de las condiciones sustentado por la teoría de la conditio sine qua non" (Goldenberg, 1984, p. 27).

La causa eficiente prescinde entonces de factores cronológicos; no resulta relevante para este juicio de causalidad lo cercanos o alejados en el tiempo que se encuentren el hecho y el daño para el establecimiento del nexo causal.

Ella eleva a la categoría de causa en sí, a la condición más activa en la producción del resultado. Trata de encontrar, dentro del amplio concurso de condiciones que intervienen en la generación de un resultado, una que, en razón de su intrínseco poder de producción del fenómeno que se aprecia como tal resultado, recibe la calificación preponderante de ser considerada su causa, lo que importa distinguir, tanto cualitativa como cuantitativamente, una condición de las demás (Trigo Represas y López Mesa, 2011, p. 418).

De ahí que, al estudiar la relación de causalidad, se deba diferenciar entre la causa, la condición y la ocasión. La primera, es decir, la causa, es aquella que ha contribuido de manera prevalente a la producción del daño. Por otro lado, la condición es aquella que gesta el entorno necesario para que la causa produzca el resultado, el cual está intrínsecamente en capacidad de producir. Por último,la ocasión favorece la producción del daño siendo prescindible para su producción.22

Así, concretando la referencia teórica en el ejemplo que se ha venido trabajando, se puede decir que la causa eficiente para la muerte de la señora es el golpe que el perro le propinó al caer. Que la caída fuese de un decimotercer

\footnotetext{
${ }^{22}$ Así lo asevera Suescún Melo, para quien "la causa eficiente es la causa propiamente dicha, es decir, responde a la pregunta: ¿por quién fue hecho el daño? Y puede definirse como aquello que por su acción produce alguna consecuencia. La condición, en cambio, no produce el efecto sino simplemente permite a la causa eficiente producirlo; descarta, si se quiere, un obstáculo permitiendo así la acción de la causa eficiente. La ocasión no hace más que favorecer el juego de la causa eficiente y en ningún modo es necesaria para la producción del daño"(2003, p. 162).
} 
piso es una condición de dicho daño, pues proporciona la altura necesaria para que el impacto tenga la magnitud suficiente para producir el efecto, pero por sí sola no tiene tal potencialidad. Como ocasión se puede catalogar el que la señora estuviere caminando para ir a algún lugar, actividad que propicia que se irrogue el daño aunque no sea necesaria para su realización.

Aunque el criterio proporcionado por la teoría en mención pareciera suficiente e idóneo para postularse como el juicio de causalidad que deben seguir los tribunales, lo cierto es que son múltiples las críticas que se le han hecho. Observa Isidoro Goldenberg que, "cuando se trata de establecer en la práctica la pauta que permita seleccionar entre las diversas condiciones de un resultado la más eficiente o la más preponderante, se advierte con nitidez la fragilidad de estas teorías. En efecto, la imposibilidad de escindir materialmente el resultado, de suyo indivisible, para atribuir a una condición per se un poder causal decisivo, hace caer dichas construcciones teóricas en un empirismo que las despoja de todo rigor científico" (2011, pp. 419-421).

$\mathrm{Si}$ bien esta teoría ha ejercido una fuerte influencia en la jurisprudencia colombiana, ${ }^{23}$ lo cierto es que no ha sido la tesis con más acogida. En realidad, ha sido la teoría de la causalidad adecuada la que mejor recepción ha mostrado tener en las cortes y en la doctrina. En tal medida, se hará un estudio más detenido sobre esta en el acápite siguiente, cerrándolo con las críticas que se le enrostran a esta teoría.

\subsubsection{La tesis de la causalidad adecuada}

La teoría de la causalidad adecuada es formulada "con la intención de limitar la responsabilidad en el campo de la causalidad, reduciendo los resultados excesivos a que conducía la teoría de la equivalencia de las condiciones" (Trigo Represas y López Mesa, 2011, p. 434). Como se mencionó, se trata de una concepción que goza de la mayor acogida tanto en la doctrina como en la jurisprudencia, lo que le ha permitido situarse en un lugar privilegiado a la hora de adelantar el juicio de causalidad en el derecho de daños. Por ello,

\footnotetext{
23 Afirmaba Suescún Melo, en su obra publicada en 2004, que "la jurisprudencia nacional ha adoptado esta teoría donde emplea, incluso, la misma terminología. En efecto, en diversos fallos han subrayado la necesidad de distinguir, de entre los hechos que intervienen en la producción de un daño, aquellos que han sido 'causa generadora' y aquellos que solamente han sido la 'ocasión'. Por su parte, sentencias españolas han hablado de la causa eficiente y necesaria como la condición que tiene una 'consideración preminente' en la producción de hecho dañoso" (2003, p. 163).
} 
resulta de suma importancia analizar qué tan eficaz es en el cumplimiento de esta finalidad, para luego plantear las críticas que se han formulado en su contra y presentar una teoría que se considera más propicia para cumplir con el reto de desentrañar este elemento axiológico de la responsabilidad civil (Tamayo Jaramillo, 2007, p. 378; Trigo Represas y López Mesa, 2011, p. 433; Goldenberg, 1984, p. 30).

Pues bien, para entrar en materia, vale la pena recordar que debemos el origen de la teoría de la causalidad adecuada a Ludwig von Bar y a Johannes von Kries. Ciertamente, se ha señalado que se trata de una construcción que "fue elaborada en su versión original por Luis Von Bar en 1871, pero su elaboración final corresponde al fisiólogo J. Von Kries, [...]” (Ortiz Gómez, 2010, p. 324). De acuerdo con Díez-Picazo, quien sigue a Trimarchi en sus planteamientos,

Von Kries subrayó que la probabilidad, entendida como frecuencia de la relación entre dos clases de eventos, es un dato a tener en cuenta a la hora de establecer relaciones causales. Hay leyes naturales - dice Von Kries- que establecen una relación de necesaria secuencia entre dos tipos de eventos, pero otras se limitan a establecer una relación de frecuencia estadística. Von Kries ponía de manifiesto la importante función que los juicios de probabilidad tienen en la vida práctica, pues las consecuencias probables de una acción pueden servir de fundamento para valorar la acción como útil o como peligrosa. Es lógico que cuando el derecho tiene por objeto la prevención de acciones dañosas prohíba acciones que no sólo han sido condiciones sqn (sine qua non) de daños, sino que también aparecen como idóneas para producirlos en el sentido que aumentan en una medida importante la probabilidad de que se verifiquen. Además, la fuerza de la probabilidad es un juicio objetivo, que tiene en cuenta las uniformidades naturales y sociales, científicamente establecidas, en el momento en que el juicio se emite, de manera que éste se realiza sobre la base de una descripción generalizadora que comprenda las circunstancias del caso (2007, p. 364).

En el mismo orden de ideas, la Corte Suprema de Justicia de Colombia ha dicho sobre esta teoría que plantea, como postulado causal esencial, que 
[...] de todos los antecedentes y condiciones que confluyen a la producción de un resultado, tiene la categoría de causa aquél que de acuerdo con la experiencia (las reglas de la vida, el sentido común, la lógica de lo razonable) sea el más 'adecuado', el más idóneo para producir el resultado, atendidas por lo demás, las específicas circunstancias que rodearon la producción del daño y sin que se puedan menospreciar de un tajo aquellas circunstancias azarosas que pudieron decidir la producción del resultado, a pesar de que normalmente no hubieran sido adecuadas para generarlo [...]. Como se ve, la gran elasticidad del esquema conceptual anotado, permite en el investigador una conveniente amplitud de movimiento. Pero ese criterio de adecuación se lo acompañó de un elemento subjetivo que le valió por parte de un sector de la doctrina críticas a la teoría en su concepción clásica (entonces y ahora conocida como de la 'causalidad adecuada'), cual es el de la previsibilidad, ya objetiva o subjetivamente considerada. Mas, dejando de lado esas honduras, toda vez que su entronque con la culpa como elemento subjetivo es evidente, $y$ éste es tema que no se toca en el recurso, el criterio que se expone y que la Corte acoge, da a entender que en la indagación que se haga —obviamente luego de ocurrido el daño [...] — debe realizarse una prognosis que dé cuenta de los varios antecedentes que hipotéticamente son causas, de modo que con la aplicación de las reglas de la experiencia y del sentido de razonabilidad a que se aludió, se excluyan aquellos antecedentes que solo coadyuvan al resultado pero que no son idóneos per se para producirlos, y se detecte aquél o aquellos que tienen esa aptitud. Sin embargo, cuando de asuntos técnicos se trata, no es el sentido común o las reglas de la vida los criterios que exclusivamente deben orientar la labor de búsqueda de la causa jurídica adecuada, dado que no proporcionan elementos de juicio en vista del conocimiento especial que se necesita, por lo que a no dudarlo cobra especial importancia la dilucidación técnica que brinden al proceso esos elementos propios de la ciencia — no conocidos por el común de las personas y de suyo sólo familiar en menor o mayor medida a aquellos que la practican-y que a fin de cuentas dan, con carácter general, las pautas que ha de tener en cuenta el juez para atribuir a un antecedente la categoría jurídica de causa. En otras palabras, un 
dictamen pericial, un documento técnico científico o un testimonio de la misma índole, entre otras pruebas, podrán ilustrar al juez sobre las reglas técnicas que la ciencia de que se trate tenga decantadas en relación con la causa probable o cierta de la producción del daño que se investiga (Díez-Picazo, 2007, p. 364).

Así las cosas, el análisis de la causalidad adecuada sugiere, para establecer el vínculo causal, que se debe determinar si un suceso era razonable y previsiblemente el más idóneo o adecuado para causar un resultado, teniendo en cuenta las máximas de la experiencia — si el asunto no requiere de un especial conocimiento técnico - o las reglas de la ciencia particular — si se trata de un asunto técnico- ${ }^{24} \mathrm{Si}$ la respuesta es positiva, esto es, si el suceso surge como idóneo para el resultado, a la luz de la experiencia y la razonabilidad, se tiene entonces que ese suceso es causa del resultado; contrario sensu, no existirá vínculo causal. A este razonamiento se le denomina prognosis póstuma. ${ }^{25}$

Nótese entonces cómo se trata de un juicio fundamentado, esencialmente, en los criterios de normalidad y probabilidad, por lo que la doctrina ha puntualizado que en la causalidad adecuada es preciso hacer, en realidad, un juicio de tipo probabilístico, que, por lo demás, se efectúa

\footnotetext{
${ }^{24}$ Sobre este juicio, López Mesa expone: "Se denomina prognosis póstumas (pronóstico objetivoretrospectivo) —o mejor, 'juicio de adecuación causal'- al procedimiento consistente en determinar ex post facto la posibilidad de un resultado en función de las condiciones precedentes" (Trigo Represas \& López Mesa, 2011, p. 451). Tamayo Jaramillo, con cita de Dalcq, así lo expresa: "Esta teoría —la de la causalidad adecuada - considera también que para ser retenido como causa de un daño, un hecho debe ser la condición necesaria de dicho daño. Entendemos por ello la condición sine qua non, es decir aquella sin la cual el daño no se habría producido. Pero contrariamente a la afirmación de los partidarios de la equivalencia de las condiciones, la teoría de la causalidad adecuada rechaza esta equivalencia y declara que no todas las condiciones necesarias podrán ser retenidas como causas; no se retendrá más que aquellas que están unidas al daño por una relación de causalidad adecuado. Bajo esta condición suplementaria, los defensores de esta teoría entienden colocarse sobre el terreno psicológico para dar de la relación de causalidad una explicación práctica. Consideran que es necesario colocarse antes del evento para analizar el nexo de causalidad, lo que les conduce a no retener como causa sino los antecedentes de los cuales debía esperarse que produjeran el resultado que se realizó. Así, pues, esta teoría tiene por efecto eliminar entre los antecedentes aquellos que no han ejercido un papel en la producción del daño, más que por un encadenamiento que puede ser considerado excepcional" (2007, pp. 378-379).

${ }^{25}$ Sobre el uso de la estadística, como análisis de probabilidad, para acreditar la causalidad en materia de responsabilidad civil, se puede consultar: Barnes (2001, p. 1).
} 
... a posteriori, ex post facto y en abstracto, esto es prescindiendo de lo que efectivamente ha ocurrido en el caso concreto, y computando únicamente aquello que sucede, conforme al curso normal y ordinario de las cosas. Rumelin hacía referencia a este fenómeno como el 'pronóstico objetivo retrospectivo'. [...] Algunos han sostenido que el juez debería colocarse en la posición del autor del hecho, tomando en cuenta las circunstancias conocidas o cognoscibles por éste. La previsibilidad en tal caso no deja de ser valorada en forma abstracta, pero circunscripta al punto de vista del sujeto y a las condiciones en las que éste actuó.

Otros, en cambio, miran el hecho siempre objetivamente: el juez debe efectuar el juicio de previsibilidad en abstracto, tomando en cuenta todas las circunstancias que un hombre normal debería prever. Finalmente, una corriente ultra-objetiva estima necesario que el juez considere todas las circunstancias eximentes, incluso aquellas que no hubieren podido ser conocidas por el agente (Pizarro, 2006, p. 99).

El resultado puede entonces variar de acuerdo con la posición que se adopte, pues, al involucrar o prescindir de uno o más hechos, la previsibilidad y la probabilidad pueden llegar a variar drásticamente.

De esta forma el juicio de causalidad dependerá en un alto grado de la capacidad del juzgador de formar un panorama lo más completo posible, quedando en todo caso una porción muy amplia a su arbitrio. ${ }^{26}$ Por tal razón se ha dicho que "esta última teoría pierde rigor científico cuando percibimos las diferencias abismales que puede haber entre un juez y otro en relación con el criterio de adecuación, ya que lo que para un juez puede ser causa adecuada de un daño, para otro puede no serlo, sin que ninguno de los dos tenga argumentos científicos que justifiquen su punto de vista" (Tamayo Jaramillo, 2007, p. 380).

\footnotetext{
${ }^{26}$ Para De Cupis, "no cabe duda de que al acoger el criterio de la regularidad causal se atribuye amplia importancia a la apreciación discrecional del juez, del que depende establecer si el daño ha sido o no un efecto regular del hecho humano. Pero en materia de relación causal, la apreciación discrecional del juez adquiere, necesariamente, una considerable importancia; y, por último, entre los varios criterios propuestos para mitigar la dureza de la teoría de la conditio sine que non, no hay duda de que la regularidad ha gozado de un mayor favor en la doctrina" (1970, p. 259).
} 
Con todo, se ha tratado de una teoría a la que se le ha reconocido una gran utilidad práctica, porque, a pesar de las subjetividades, pareciera brindar una explicación intuitivamente acertada de lo que sucede en el mundo cuando afirmamos que un fenómeno es causa de otro.

Pero ¿es la causalidad adecuada una verdadera y genuina teoría sobre lo que conocemos como nexo causal? La alusión a criterios de selección normativa, como la probabilidad y las máximas de la experiencia, ha develado que la causa adecuada no hace un examen de causalidad puramente físico o naturalístico, sino que, por el contrario, parezca más una herramienta de selección de la causa jurídicamente relevante, a partir de un conjunto dado de causas naturales. Puesto en otros términos, la causalidad adecuada no responde cuáles son las causas físicas o naturales de un determinado evento, sino que brinda unos parámetros conforme a los cuales se puede escoger, dentro de un determinado grupo de causas, cuál es la que resulta jurídicamente más relevante.

No en vano, Pizarro señala, por ejemplo, que,

más allá de las objeciones, la doctrina de la relación causal adecuada tuvo el mérito de fundar sobre bases razonablemente objetivas, superadoras del empirismo reinante hasta ese momento, un criterio de delimitación de imputación. No es, en verdad, como bien se ha dicho, una genuina teoría causal, en tanto no luce orientada a determinar si un elemento de hecho es la causa de un resultado. Su finalidad es más específica: establecer si determinados hechos deben ser considerados relevantes, desde una perspectiva jurídica, para formular la imputación de sus consecuencias a una determinada persona. La teoría de la causalidad adecuada es, en esencia, una teoría de la imputación objetiva, que permite con unos criterios normativos más o menos ciertos, cuando un resultado puede ser atribuido a un comportamiento (2006, p. 99).

Así, la causa adecuada pareciera ser idónea para resolver la pregunta por cuál es la causa jurídicamente relevante y no para esclarecer cuándo un fenómeno es causante de otro, en el sentido natural de la expresión 'causa'. Esto ha sido claramente entendido en otros ordenamientos jurídicos en los que la adecuación es comprendida en su justa dimensión, esto es, como un criterio de imputación o selección causal y no como un derrotero para determinar la causalidad natural. Así se ha hecho, por ejemplo, en España, Alemania o, incluso, en los 
Principios de Derecho Europeo de la Responsabilidad (PETL, por su sigla en inglés), que reflejan el estado más avanzado del debate.

$\mathrm{El}$ inconveniente, sin embargo, es que en Colombia este aspecto no ha sido diáfanamente aprehendido. En nuestro contexto local, la teoría de la causalidad adecuada ha sido estudiada y aplicada como un criterio de causalidad fáctica o natural, y no como una forma de imputación o selección de causas. Con ello, se ha desfigurado su alcance real, lo que ha conducido a que, en ocasiones, lleve a resultados inverosímiles o contraintuitivos. Un ejemplo puede resultar muy claro para ilustrar esta problemática.

A le da a B un golpe en la cabeza, insuficiente para provocar una lesión
en un ser normal. Pero ocurre que B está afectado de una debilidad
congénita de los huesos del cráneo y ese golpe le basta para matarlo.El
resultado se produjo pues, pese a que el acto que ha sido la condición
de ello no debía normalmente tener semejante efecto. La teoría de
la causalidad adecuada conducirá a considerar la debilidad particular
de los huesos del cráneo de B como un evento excepcional, y a con-
siderar desde luego que el acto de A no es la causa del daño porque
esta consecuencia no era previsible (Tamayo Jaramillo, 2007, p. 379).

Sin embargo, la intuición más elemental llegaría a la solución justamente opuesta: el golpe, independientemente de la situación atípica o anormal, es la causa fáctica del daño producido sobre B. Cosa distinta es si dicha causa resulta jurídicamente relevante a efectos de comprometer su responsabilidad, pero lo cierto es que, desde una perspectiva estrictamente causal, el impacto en el cráneo fue el que condujo al resultado. El problema es que, en cualquier caso, esa no es la respuesta a la que llega la causalidad adecuada. De manera contraintuitiva, como se mencionó, este criterio causal indicaría que el golpe no fue la causa del daño. Por esta falencia, algunos teóricos se han encargado de agregarle a la causalidad adecuada elementos que permitan sopesar antecedentes que solo de forma anormal o azarosa producen el resultado. De ahí que se hayan añadido aditamentos que, con la ayuda que las ciencias forenses 
prestan a este propósito, permiten que aun en esos raros casos, y junto con la 'lógica de lo razonable' (Recasens), dichos eventos puedan esclarecerse. ${ }^{27}$

No obstante, estos aditamentos, de una parte, no han resuelto el problema en la práctica, comoquiera que no se puede inventar un nuevo criterio para la causalidad adecuada con cada situación particular que surge en el mundo fáctico; pero, además, tampoco han sido capaces de resolver el problema de fondo, cual es el verdadero enfoque de la adecuación como un criterio de selección de causas (imputación) y no como un derrotero para determinar la causa real o causa de hecho.

Esta circunstancia nos permite entonces afirmar que, en la actualidad, ordenamientos como el colombiano enfrentan una verdadera crisis de la causalidad. Las teorías tradicionales se han mostrado insuficientes para resolver muchos de los problemas que, en la práctica, suponen los problemas de la responsabilidad civil. De hecho, la concepción más difundida hoy en día, que es la causalidad adecuada, no solamente está desenfocada desde su perspectiva teórica - comoquiera que es tratada como una teoría de la causalidad fáctica cuando, en realidad, surge como un criterio de imputación- - , sino que, además, conduce a resultados contraintuitivos que han llevado a que se le sumen millones de criterios casuistas que, en general, reflejan el fracaso de la teoría como una versión explicativa de la causalidad.

Esto demuestra la necesidad de incentivar entonces una reingeniería significativa del concepto de causalidad en los ordenamientos que, como el colombiano, presentan los problemas antes descritos. En la propuesta que se esboza a continuación, se propone dicha reingeniería, la cual parte de adoptar ciertas figuras que ya existen en el derecho comparado y que podrían solucionar varios de los problemas antes descritos.

\footnotetext{
${ }^{27}$ Sobre la teoría formulada por Recasens, el profesor Tamayo Jaramillo dice: "El nexo causal se puede afirmar científicamente, pero su inexistencia o ruptura jurídica no siempre se puede decidir exclusivamente con criterio científico. En ese sentido pensamos que la teoría del logos propuesta por Luis Recasens Siches y por Chaïm Perelman es de gran utilidad en la solución de este problema. De acuerdo con dicha teoría, cuando el juez debe decidir un proceso de responsabilidad civil no puede condenar a quien no haya causado el daño; pero no es lógico que desde el punto de vista de lo razonable excluya ciertos eventos que, aunque participaron físicamente en la producción del daño,jurídicamente deben considerarse extraños al hecho. El error de la doctrina tradicional consiste en olvidar que se están juzgando conductas humanas y que, por tanto, el buen sentido deber orientar al fallado al momento de decidir si la conducta del agente es o no una causa del daño" $(2007$, p. 381).
} 


\subsubsection{Causalidad de hecho y causalidad de derecho. Hacía una teoría de la imputación objetiva ${ }^{28}$}

El primer eje de la propuesta tiene que ver con la incorporación de una distinción estructural: la que diferencia entre causalidad de hecho y causalidad de derecho, más propiamente denominada imputación objetiva. El derecho de daños colombiano no conoce formalmente esta oposición entre causalidad de hecho y causalidad de derecho. Como se evidenció previamente, la aplicación de la teoría de la causa adecuada como esquema dogmático de causalidad fáctica o natural da lugar a múltiples equívocos, los cuales pueden zanjarse a partir de esta diferenciación. Al introducir la imputación en el estudio de la causalidad fáctica, como sucede bajo la teoría de la causa adecuada cuando es empleada confusamente, se presentan los resultados absurdos, desde el punto de vista causal, que se expusieron previamente y que hacen que esta construcción dogmática no emerja como la ideal para adelantar el juicio de causalidad. ${ }^{29}$

De ahí que en diferentes latitudes se haya propugnado por la distinción entre causalidad de hecho y causalidad de derecho, aunque esta no sea la denominación más acertada. Con ello se procura evitar la confusión teórica y los resultados contraintuitivos que se presentan cuando una teoría propia de la causalidad de derecho o imputación objetiva — como es la teoría de la causa adecuada - es empleada como criterio para dilucidar la causalidad fáctica, de hecho o meramente naturalística.

${ }^{28}$ Como lo hace la doctrinante española Múrtula, es importante apuntar que "no está demás señalar en este punto que no debemos confundir la llamada 'responsabilidad objetiva o sin culpa' con la teoría de la 'imputación objetiva'. Así, mientras que esta última resuelve la relevancia jurídica de los elementos causales, una vez verificado el nexo causal (de acuerdo con la teoría de la equivalencia de las condiciones), a través de criterios normativos por los cuales un resultado puede ser atribuible a un comportamiento; la responsabilidad objetiva actuaría a posteriori en el juicio de responsabilidad, atribuyendo la responsabilidad al sujeto en función del riesgo creado con su actividad, que a su vez le reporta beneficios" (2005, p. 84).

${ }^{29}$ Dice Fernando Pantaleón, citado por Santos Ballesteros, que "el derecho no puede sino partir del concepto de causalidad propio de la lógica y de las ciencias de la naturaleza: la llamada concepción nomológico-funcional de la causalidad. Los operadores jurídicos no son productores, sino consumidores de leyes causales. Por ello puede afirmarse que la decisión sobre la existencia o no de la relación de causalidad es una cuestión de hecho libre de valoraciones específicamente normativas. Por el contrario, el problema de la imputación objetiva - la función de cuyos criterios es evitar que sean puestas a cargo del responsable absolutamente todas las consecuencias de las que su conducta es causa- es una cuestión puramente jurídica, un problema de valoración a resolver con las pautas más o menos precisas, ofrecidas por el sistema normativo de responsabilidad. No es correcto, por tanto, considerar las que verdaderamente son teorías de la imputación objetiva — entre ellas la mal llamada teoría de la causalidad adecuada— como si se tratara de teorías sobre la relación de causalidad”(2013, p. 376). 
Esta dicotomía propone entonces distinguir entre la causalidad de hecho y la causalidad de derecho para indicar que el examen causal debe partir, en un primer estadio, de la verificación fáctica del nexo - o verificación naturalística, fundamentada en los criterios de la ciencia y de la física- (causalidad de hecho) y, una vez determinado el conjunto de causas fácticas, seleccionar aquella o aquellas que resulten jurídicamente relevantes (causalidad de derecho) (Martín Casals, 2011).

Puesto en otros términos, esta es una teoría que le indica al intérprete que el estudio de la causalidad no se agota en la aplicación de una sola fase, sino que, por el contrario, requiere de dos etapas o estadios: uno primero, en el que se determina si fácticamente un suceso puede ser considerado como causa del otro (causalidad de hecho), y otro en el que se escogen, de las causas fácticas, aquellas que revisten importancia jurídica (causalidad de derecho) (Spier, 2012, pp. 79 y ss.). Este último estadio de selección es también conocido como 'imputación objetiva' en la medida en que determina cuándo un resultado dañoso, además de ser originado fácticamente en un determinado suceso o actuación, le es también imputable objetivamente a dicha actuación, esto es, le es atribuible en términos jurídicos.

Ahora bien, para determinar los criterios conforme a los cuales debe analizarse la causalidad de hecho y la causalidad de derecho, existen múltiples posturas. Con todo, la más difundida indica que la primera de las causalidades (causalidad de hecho) debe analizarse conforme al test sine qua non (que es el que emplea la equivalencia de las condiciones, antes explicada), mientras que la segunda (causalidad de derecho) se mira conforme a la causalidad adecuada. Así las cosas, para los ordenamientos en los que existe esta postura, lo primero que debe hacer el operador jurídico es determinar qué sucesos pueden considerarse como causa conforme a la regla sine qua non para luego seleccionar, de ese conjunto de causas naturales, cuál es la causa jurídicamente relevante (imputación objetiva) (Gil Botero, 2012, pp. 484 y ss.), de acuerdo con la causalidad adecuada.

Esta es, en esencia, la teoría de la imputación objetiva, ${ }^{30}$ en la cual, en palabras de Enrique Gil Botero,

\footnotetext{
${ }^{30}$ Sobre el origen de la imputación objetiva, se dice que "se encuentra en la escuela filosófica funcionalista planteada inicialmente por Jeremy Bentham (desde el utilitarismo), y luego fue retomada y desarrollada por el profesor Niklas Luhman, quien desarrolló la teoría de los sistemas sociales y, por lo
} 
una vez constatada o verificada la existencia de un daño, es indiscutible que este tuvo una génesis material o causal, hecho que es irrelevante para el derecho, precisamente porque se mantiene en el plano de las ciencias naturales, es decir, en relación causa-efecto. Por el contrario, verificada la existencia de un daño desde la dimensión jurídica, lo relevante es establecer a quién es atribuible esa afectación que sufre una determinada persona en sus derechos, bienes o intereses legítimos.

Es precisamente en ese específico escenario donde el término imputación supone un análisis bifronte o dual consistente en la verificación de que el daño es tanto fáctica (imputatio facti) como jurídicamente (imputatio iure) imputable. La imputación fáctica tiene como propósito determinar si en el plano material, mas no necesariamente causal,

tanto, la importancia de asignación de roles a cargo de los asociados en una organización de personas. Esta visión funcionalista surge como una respuesta a la teoría del finalismo penal cuyo principal defensor fue Hans Welzel, para quien la voluntad y el querer del sujeto de derecho responsable del daño se incorpora al concepto de acción [...] motivo por el cual pasó a ser conocida como la 'teoría final de la acción', cuyo sustrato principal se hallaba en las teorías causales de las ciencias naturales o empíricas, consideración adicional por la que se defendía bajo este paradigma una imputación netamente subjetiva (imputación subjetiva) fundamentada única y exclusivamente en la cognoscibilidad y exigibilidad esperada del sujeto - aspectos pertenecientes al fuero interno del actor del daño o del delito—. Esta perspectiva, como lo destaca la doctrina, consistió en el desplazamiento que generó el positivismo naturalístico en el derecho penal respecto de la causalidad propia de las ciencias exactas, en donde no caben hechos indiscutibles, sino únicamente los comprobables materialmente" (Gil Botero, 2013, pp. 478-479). Sobre el camino que ha seguido esta teoría, Ortiz Gómez enseña: "Esta distinción fue hecha por primera vez para el derecho civil por el alemán Karl Larenz. La teoría, tal como la conocemos hoy, fue recogida por el penalista alemán Gunter Jakobs, y se basa en el principio de confianza: suponemos que cada uno de los actores sociales hace lo que tiene que hace, según Jakobs: 'Si en todo contacto social todos hubiesen de considerar todas las consecuencias posibles desde el punto de vista cognitivo, la sociedad quedaría paralizada. No se construiría ni se matricularía ningún automóvil, no se produciría ni se serviría alcohol, etc., y ello hasta el extremo de que a la hora de pagar sus deudas todo el mundo debería prestar atención a que el acreedor no planease realizar algo ilícito con el dinero recibido'. Así las cosas, Jakobs parte de la necesidad de que cada persona actúe de acuerdo con su función social. La teoría del imputación objetiva fue traída al derecho civil por el profesor Fernando Pantaleón en 1990. Advierte que el tema de causa no es un problema jurídico, sino de hecho, y así las cosas, el problema de la causa es radicalmente distinto de la reflexión jurídica de poner a cargo de una persona una conducta como obra de su autor. Lo anterior significa que los abogados no podemos inventarnos la causalidad, porque eso sería tanto como desconocer lo que ocurre en el mundo real; sería inventar un universo paralelo donde todo se explicara jurídicamente: los operadores jurídicos no son 'productores' sino 'consumidores' de leyes causales. Dado el reciente planteamiento de la teoría del derecho civil, esta debe entenderse como una teoría en construcción, [...]" (2010, p. 328). 
el daño es atribuible o no a un sujeto de derecho. Así las cosas, antes de abordar el análisis de la imputación jurídica o el fundamento de la responsabilidad, es imprescindible que la lesión o afectación antijurídica esté radicada en cabeza de la entidad o del sujeto pasivo de la relación.

Una vez constatado lo anterior, es posible abordar el análisis sobre la imputación jurídica, esto es, si existe o no un fundamento normativo que concrete, en el caso específico, la obligación de resarcir el daño antijurídico. En otros términos, la imputación fáctica con ella la imputación objetiva del daño- consiste en un estudio retrospectivo que recae sobre la acción u omisión del sujeto, mientras que la imputación jurídica supone la realización de un análisis prospectivo y netamente normativo dirigido a determinar si, una vez establecida la atribución material del daño, existe o no el deber jurídico — subjetivo u objetivo- de resarcir el perjuicio.

Así mismo, resulta pertinente destacar que el hecho de que la imputación fáctica tenga un sustrato o contenido material no quiere significar que esté desprovista de conceptos o construcciones normativas o jurídicas y, por lo tanto, es allí donde la imputación objetiva y todos sus elementos delimitadores se conectan para suministrar una serie de herramientas a la hora de valorar cuándo es imputable o no un daño (Gil Botero, 2013, pp. 474-475).

Nótese entonces cómo se parte de un escenario dicotómico en el que se diferencia entre dos estadios de análisis ya explicados: el de la causa de hecho o causalidad fáctica, que responde a la cuestión de si un determinado fenómeno es, desde el punto de vista naturalista, el detonante de un resultado, para luego pasar a la fase de la causa de derecho o imputación objetiva, que sirve para seleccionar cuál es la causa jurídicamente relevante dentro del consabido grupo de causas naturalistas o de hecho. ${ }^{31}$

\footnotetext{
${ }^{31}$ Sobre esta dicotomía se ha afirmado, desde lo penal, que "la imputación objetiva, en sus inicios, surge vinculada al problema de la teoría de la relevancia típica que aparece en la dogmática neoclásica, neokantiana, caracterizada fundamentalmente por el llamado dualismo metodológico que, al contrario de lo que acontecía con el método naturalista, afirmó que uno era el método de las ciencias naturales y otro el de las ciencias sociales, pues al paso que aquellas se soportan en causalidad, en estas su suporte es la filosofía de los valores. Con esta separación la dogmática neokantiana hizo una yuxtaposición del valor
} 
Ahora bien, para acometer el primero de los estadios del análisis, esto es, el de la causalidad de hecho, se decía entonces que se requiere de un criterio que permita determinar, con cierta fiabilidad, cuáles son los sucesos que desde la óptica meramente fáctica o científica pueden considerarse como causas del resultado. Para ello se ha recurrido entonces al que pareciera ser el test más idóneo, que es el de la conditio sine qua non, empleado por la teoría de la equivalencia de las condiciones.

Ciertamente, como ya se puso de presente en un segmento precedente, aunque este criterio ha sido criticado como teoría predominante de la causalidad, ha demostrado ser de gran utilidad cuando se le emplea única y exclusivamente con el propósito de verificar cuáles son las causas físicas o naturales de un fenómeno. El test sine qua non, basado en el explicado juicio contrafáctico, es muy apropiado para identificar todo el conjunto de variables que hicieron posible la ocurrencia de un suceso, comoquiera que permite determinar cuándo, al omitir una de tales variables, desaparece el resultado. En ese sentido, desde un punto de vista estrictamente físico, se erige como una teoría muy sugestiva.

Puesto en otros términos, al emplear un juicio contrafáctico, el test sine qua non permite dilucidar, definitivamente, qué factores han sido decisivos en la producción del resultado, comoquiera que evalúa en ausencia de cuáles de ellos desaparece la consecuencia analizada. Este razonamiento tan básico conduce, en últimas, a esclarecer el universo de causas determinantes en el acaecimiento del desenlace final, lo que hace de esta idea un postulado muy sugestivo en lo que a la causalidad fáctica se refiere.

\footnotetext{
frente a la realidad, haciendo desaparecer la fusión entre el ser y el deber ser que, más adelante, reaparece con la dogmática finalista al entender la acción como una unidad de sentido en que se funde, nuevamente, el valor con el ser, tal como la entendía Wezel. [...] Otra repercusión de la dogmática neokantiana, con su dualismo metodológico, fue la teoría de la relevancia típica que parte de la teoría causal de la equivalencia de las condiciones, en donde todas las condiciones contribuyen por igual a la producción del resultado en la medida en que si se suprime, mentalmente, una de ellas el resultado no se consigue, de conformidad con la teoría de la conditio sine qua non. Pero si bien para la teoría de la relevancia típica todas las condiciones tienen idéntico valor desde el punto de vista causal, no todas las condiciones son relevantes para el tipo penal. [...] En principio, entonces, la teoría de la imputación objetiva surge como un desarrollo de relevancia típica vinculada, inicialmente, a solucionar fundamentalmente el problema de la atribución de resultados, es decir, determinar si se puede imputar el resultado a una determinada persona, tal como en sus inicios la concibió Roxin"(Villanueva, 2011, pp. 55-57).
} 
El problema se presenta cuando se le emplea como un criterio jurídico, toda vez que, al evaluar todas las posibles causas como equivalentes, no permite seleccionar aquella que es jurídicamente relevante y, por el contrario, propicia un regreso al infinito. Por eso se ha dicho que el test sine qua non es muy efectivo para esclarecer el conjunto de causas físicas de un hecho, pero muy pobre para determinar la causa que interesa al derecho. También por esto es por lo que es un criterio ideal para la causalidad de hecho, aun cuando no para la imputación objetiva o causalidad de derecho, que es justamente lo que se ha hecho en otros sistemas comparados y lo que se propone en este escrito.

No en vano expresa Javier Tamayo Jaramillo:

Cualquiera que sea la teoría de la causalidad que se acoja, lo cierto es que [...] siempre es indispensable que el fenómeno que se estudia como posible causa sea conditio sine qua non del daño. Es decir, desde el punto de vista jurídico, solo se considera causa del daño aquel fenómeno sin el cual el daño no se habría producido. Ello significa que si, en el caso concreto, el juez llega a la conclusión de que el daño de todas maneras se habría producido así no hubiera concurrido la culpa del demandado este no se considera causante de ese daño (Tamayo Jaramillo, 2007, p. 384). ${ }^{32}$

El empleo del test sine qua non como criterio de imputación fáctica es retomado, por lo demás, por la experiencia comparada, que reconoce las bondades de distinguir entre causa de hecho y causa de derecho, y, a su turno, de emplear el mencionado test como el idóneo para dilucidar la primera de las hipótesis. Así lo han hecho, por ejemplo, los Principios de Derecho Europeo de la Responsabilidad Civil en su artículo 3:101 (Conditio sine qua non), el cual indica que "una actividad o conducta (en adelante actividad) es causa del daño de la víctima si, de haber faltado la actividad, el daño no se hubiera producido". 33

\footnotetext{
32 En el mismo sentido, Salvador Coderch y Fernández Crende apuntan: "En una primera aproximación, la causalidad, entendida como causalidad de hecho, se determina por mediación del criterio de la conditio sine qua non (but-for test): hay causalidad cuando el daño no hubiera ocurrido de no haberse realizado la conducta, por acción u omisión del demandado"(2006, p. 3).

${ }^{33}$ Sobre las tendencias europeas en la materia, el profesor Patrice Jourdain afirma: "Le droit français ne définit pas le lien de causalité. Il n’indique explicitement sa préférence pour aucune des théories proposées par
} 
Ahora bien, en lo que tiene que ver con la segunda fase del análisis de la causalidad, esto es, con la causalidad de derecho o imputación objetiva, ha dicho el profesor Yzquierdo que

resulta desde esta perspectiva una auténtica cuestión de derecho [...]. Una vez decidido que existe relación causal, resta ver si, existiendo varios protagonistas en la secuencia, ha de ser uno u otro el que responda, y de cuántas consecuencias. Y para ello podrán servir el criterio de la adecuación, el de la eficiencia, el de la proximidad o el que sea. Pero esto es ya un problema de imputación objetiva, no de causalidad. Ya no se trata de una cuestión dejada a la exclusiva soberanía del tribunal de instancia, sino de una auténtica quaestio iuris cuyo tratamiento uniforme corresponde adoptar precisamente al Tribunal Supremo (2010, p. 329).34

Así, en lo que consiste la imputación objetiva o causalidad de derecho es, esencialmente, en una etapa de selección; una etapa en la que, dado un conjunto de causas físicas del resultado, se escoge cuál de todas ellas es la que resulta

la doctrine. Les projets de réforme ne le font pas davantage, les rédacteurs ayant refusé de prendre un parti qui aurait risqué d'être aussitôt démenti par les tribunaux, eu égard à leur pratique habituelle. À cet égard les projets européens tranchent nettement avec notre droit. Les PETL énoncent à l'art. 3:101 : 'Est considérée comme cause du dommage subi par la victime toute activité ou conduite (ci-après « activité ») en l'absence de laquelle le dommage ne serait pas survenu' et les auteurs du DCFR sont dans le même sens, dans l'art. 4:101: 'Une personne cause à autrui un dommage juridiquement pertinent si ce dommage doit être considéré comme une conséquence de la conduite de cette personne ou de la source de danger dont la personne est responsable'. Néanmoins, derrière cette différence formelle, on retrouve une idée semblable. Les textes européens optent tous deux pour la doctrine dite de l'équivalence des conditions ou de la condition sine qua non, que ne renie nullement le droit français. Bien des auteurs estiment d'ailleurs quelle représente dans la jurisprudence française la tendance dominante, à défaut de constituer un véritable principe. Souvent en effet les juges commencent par élaborer un raisonnement contrefactuel (ou but for test) en se demandant si, sans le fait (c’est-à-dire dans un scénario contraire à celui de l'espèce), le dommage se serait quand même produit. La causalité ne sera admise quien cas de réponse négative, c'est-à-dire si le fait apparaît comme une cause nécessaire du dommage. De ce point de vue, le caractère plus ou moins direct du lien comme la concurrence d'autres causes du dommage, simultanées ou successives, sont normalement sans incidence. Au stade des principes, droit français et projets européens convergent largement"(2014).

${ }^{34} \mathrm{El}$ profesor Ortiz Gómez afirma que "la imputación objetiva en el derecho civil propone una serie de criterios que llevan a no imputar la conducta al agresor. Dicho de otra manera: los criterios expuestos a continuación son criterios de exclusión de la imputación, de modo que si se da cualquiera de ellos, se llegará a la conclusión de que el agresor causó físicamente los daños, pero que jurídicamente no le son imputables y en consecuencia no responde, dado que los daños no resultan directos” (2010, p. 329). 
jurídicamente relevante y, de contera, la que puede llevar a que se comprometa la responsabilidad. Entonces,

su aplicación sirve para negar la equiparación absoluta entre la prueba de la relación de causalidad — strictu sensu o causalidad fáctica o material- y la atribución de responsabilidad civil. Conforme esta teoría, que goza cada día de mayor predicamento en la doctrina civil, el problema causal se reduce - $\mathrm{o}$ se extiende - a través de diversos criterios de imputación (como el de exclusión del 'riesgo general de la vida', o el criterio de la 'prohibición de regreso', etc.), que si bien no son dogmas de contornos perfectamente dibujados (sino que tienen un cierto halo de imprecisión, pudiéndose presentar, además, de una manera interrelacionada y no excluyente), son, sin embargo, instrumentos útiles para configurar la relación de causalidad (Múrtula, 2005,p. 84).35

Ahora bien, como lo indica la profesora Virginia Múrtula Lafuente, para la selección de las causas jurídicas relevantes se puede emplear toda una serie de parámetros normativos, en los términos antes expuestos.

Así, por ejemplo, los citados Principios de Derecho Europeo de la Responsabilidad Civil, tomando la distinción entre causalidad de hecho y causalidad de derecho, contienen en su artículo 3:201 los criterios de imputación objetiva de un daño. En dicha norma, se ordena

que si una actividad es causa en el sentido de la sección 1 de este capítulo [Conditio sine qua non], la cuestión de si puede ser imputada a una persona y en qué medida depende de factores como los siguientes:

a) la previsibilidad del daño para una persona razonable en el momento de producirse la actividad considerando, en especial, la cercanía en el tiempo y en el espacio entre la actividad dañosa y su consecuencia, o la magnitud del daño en relación con las consecuencias normales de tal actividad;

b) la naturaleza y valor del interés protegido (artículo 2:102);

${ }^{35}$ Sobre los diferentes criterios de imputación objetiva, se puede ver: Díez-Picazo (2007, pp. 372 y ss.), Gil Botero (2013, pp. 480 y ss.), Navarro (2013, pp. 200 y ss.), Ortiz Gómez (2010, pp. 329 y ss.), Salvador Coderch y Fernández Crende (2006, pp. 7 y ss.). 
c) el fundamento de la responsabilidad (artículo 1:101);

d) el alcance de los riesgos ordinarios de la vida; y el fin de protección de la norma que ha sido violada. ${ }^{36}$

\title{
De esto criterios de imputación objetiva, se hace especial mención al deno- minado criterio de la adecuación, consagrado en el literal a) del artículo ante- riormente mencionado, y en virtud del cual, tomando los postulados de la teoría de la causalidad adecuada,
}

\author{
solo se puede imputar el daño a aquel cuya conducta resulta muy \\ probable como causante del daño, según la reflexión hecha por un \\ observador que deberá tener en cuenta los conocimientos especiales
}

\footnotetext{
${ }^{36}$ En el comentario que sobre el particular se hace a este artículo, se explica: "A los efectos prácticos, cada uno de los ordenamientos jurídicos europeos tenidos en cuenta acepta que el mero hecho de que se determine una conditio sine qua non entre un daño y una actividad no significa que todos y cada uno de los daños posteriores tengan que ser indemnizados por la persona responsable. Como ya se ha mencionado más arriba, esto parece cierto incluso con respecto a Bélgica y Francia. En el fondo, el resultado de las sentencias de los tribunales de ambos países no es significativamente diferente si lo comparamos con el de otros países objeto de análisis. La diferencia real entre los distintos ordenamientos jurídicos parece consistir en que algunos perciben la cuestión tratada por el artículo 3:201 como un instrumento jurídico carente de cualquier relación con ella. No obstante, (hablando en términos teóricos) con las excepciones que se acaban de mencionar, cada ordenamiento jurídico reconoce - por supuesto- que el cielo no puede ser el límite. Así pues, a efectos prácticos las diferencias son muy limitadas. Hemos intentado evitar los debates de este tipo distinguiendo entre la conditio sine qua non (sección 1) y el alcance de la responsabilidad (sección 2), que se encuentran juntos en el capítulo 3 (relación de causalidad). [...] El artículo 3:201 sólo entra en juego si el requisito de la sección 1 se cumple. Ello significa que una causa potencial, concurrente o alternativa puede ser suficiente. [...] Los factores mencionados en el artículo 3:201 letras a-e se han extraído de una seria de casos que a su vez están tomados de la jurisprudencia nacional o inspirados en ella. Esta lista no es exhaustiva. Por esta razón hablamos de 'factores como los siguientes'. En la mayoría de los casos operarán diversos factores: (a),(b) y (e) son probablemente los más importantes. Como regla general, la responsabilidad no puede establecerse fácilmente si el daño no era razonablemente previsible en el momento en que la actividad se llevó a cabo, mientras que se requiere una atribución cautelosa si el criterio mencionado en el apartador (e) no se cumple. No obstante, pueden aplicarse excepciones, por ejemplo en caso de dolo. Además, en especial en los casos de daños corporales (graves), puede resultar que se requiera una atribución más generosa para cumplir con las exigencias de la justicia. Esto último puede ilustrarse mediante los bien conocidos casos de la 'cáscara de huevo'. Este tipo de casos son relativamente raros y por esta precisa razón no son previsibles en la realidad. No obstante, este daño será imputable al responsable. Los factores relevantes pueden muy bien apuntar en direcciones distintas. Por ejemplo, el daño corporal merece una protección más intensa (artículo 2:102, párrafo 2). La responsabilidad objetiva (artículo 5:101) puede constituir una razón para que se sea reacio a imponer un alcance de la responsabilidad muy amplio. En estos casos - y en otros muchos- los factores relevantes tienen que ser ponderados unos con otros"(Ordoqui Castilla, 2011, pp. 98-100).
} 
con que contaba el agresor al momento de causar el hecho. Este observador debe considerar la cuestión ex ante. Si según el observador el hecho no es causa normalmente imputable a su autor, en ese sentido diríamos que no hay nexo jurídico entre la conducta (hecho) y el daño. Este criterio difiere de la teoría de la causalidad adecuada en quien hace la reflexión: se trata de un observador experto (Ortiz Gómez, 2010, p. 329).

El criterio de la adecuación permite acometer una adecuada selección de causas, a partir de parámetros que son de interés del derecho, como la normalidad y la previsibilidad. Así, en casos como el de la fragilidad ósea, antes comentado, se puede llegar a un resultado más coherente y sostenible: el golpe que se le propine a un sujeto que padezca esta enfermedad será, en definitiva, la causa física del resultado, aun cuando, desde la óptica de la imputación objetiva, no le será objetivamente imputable al autor, dada su anormalidad e imprevisibilidad.

Nótese cómo la distinción ofrece entonces indiscutibles ventajas:

En el ámbito colombiano, la jurisdicción de lo contencioso administrativo ha sido precursora de la aplicación de esta teoría al ámbito de la responsabilidad extracontractual del Estado. ${ }^{37}$ En reiterados pronunciamientos, el Consejo de Estado ha echado mano de la teoría de la imputación objetiva para señalar a las entidades estatales como responsables del daño e imponerles la obligación de reparar.

Así, en diversas sentencias ha precisado, al reconocer diferencia entre imputación fáctica e imputación jurídica, que

en cuanto a la imputación exige analizar dos esferas: a) el ámbito fáctico y b) la imputación jurídica, en la que se debe determinar la atribución conforme a un deber jurídico (que opera conforme a los distintos títulos de imputación consolidados en el precedente de la Sala: falla o falta en la prestación del servicio — simple, presunta y

\footnotetext{
37 Con todo, valga aclarar, por su génesis penal, que la imputación objetiva fue utilizada primariamente para la imputación de un resultado por los tribunales de dicha especialidad. Así, se ha dicho que "fue la Sala Penal del Tribunal Superior de Bogotá, jalonada por sentencias y salvamentos de voto del ex magistrado Abelardo Rivera Llano, el juez que empezó, desde 1994, a utilizar los criterios de imputación objetiva para resolver asuntos relacionados con delitos culposos [...]" (Villanueva, 2011,p. 133).
} 
probada—; daño especial — desequilibrio de las cargas públicas, daño anormal—; riesgo excepcional. Adicionalmente, resulta relevante tener en cuenta los aspectos de la teoría de la imputación objetiva de la responsabilidad patrimonial del Estado. [...] Sin duda, en la actualidad todo régimen de responsabilidad patrimonial del Estado exige la afirmación del principio de imputabilidad, según el cual la indemnización del daño antijurídico cabe achacarla al Estado cuando haya el sustento fáctico y la atribución jurídica. Debe quedar claro que el derecho no puede apartarse de las "estructuras reales si quiere tener alguna eficacia sobre las mismas". En cuanto a esto, cabe precisar que la tendencia de la responsabilidad del Estado en la actualidad está marcada por la imputación objetiva, título autónomo que "parte de los límites de lo previsible por una persona prudente a la hora de adoptar las decisiones”. Siendo esto así, la imputación objetiva implica la 'atribución', lo que denota en lenguaje filosófico-jurídico una prescripción, más que una descripción. Luego, la contribución que nos ofrece la imputación objetiva, cuando hay lugar a su aplicación, es la de rechazar la simple averiguación descriptiva, instrumental y empírica de "cuando un resultado lesivo es verdaderamente obra del autor de una determinada conducta”. [...]. Dicha tendencia es la que marcó el precedente jurisprudencial constitucional, pero ampliando la consideración de la imputación (desde la perspectiva de la imputación objetiva) a la posición de garante donde la exigencia del principio de proporcionalidad es necesaria para considerar si cabía la adopción de medidas razonables para prevenir la producción del daño antijurídico, y así se motivara el juicio de imputación. Dicho juicio, en este marco, obedece sin lugar a dudas a un ejercicio de la ponderación que el juez está llamado a aplicar, de tal manera que se aplique como máxima que "Cuanto mayor sea el grado de la no satisfacción o del detrimento de un principio, mayor debe ser la importancia de satisfacción del otro". [...] la responsabilidad extracontractual del Estado se puede configurar una vez se demuestre el daño antijurídico y la 


\author{
imputación (desde el ámbito fáctico y jurídico) (Consejo de Estado, \\ sentencia del 19 de agosto de 2011). ${ }^{38}$
}

\begin{abstract}
${ }^{38}$ En el mismo orden de ideas, se pronunció el Consejo de Estado, al afirmar que “[...] si la ciencia jurídica parte del supuesto de atribuir o endilgar las consecuencias jurídicas de un resultado (sanción), previa la constatación de que una transgresión se enmarca en una específica proposición normativa, es evidente que el nexo causal por sí mismo deviene insuficiente para solucionar el problema de la atribución de resultados, tal y como desde hace varios años se viene demostrando por el derecho penal, lo que ha conllevado que se deseche el principio de causalidad a efectos de imputar un hecho, para dar aplicación a una serie de instrumentos e ingredientes normativos ( $v . g r$., el incremento del riesgo permitido, la posición de garante, el principio de confianza, la prohibición de regreso, etc.) dirigidos a establecer cuándo determinado resultado es imputable a un sujeto. Lo anterior, comoquiera que es posible que un determinado suceso tenga origen material en una específica conducta (causa material), pero las consecuencias del mismo sean atribuidas a un tercero ( $v . g r$., la responsabilidad por el hecho de las cosas, o por el hecho de otro" (Consejo de Estado, sentencia del 26 de marzo de 2009). En esta misma línea, en la sentencia del 9 de junio de 2010, se dio aplicación a la imputación objetiva en los siguientes términos: "En el caso concreto, el análisis de imputación desborda el plano de lo material y fáctico para ubicarse en un escenario normativo que se traduce, en sí mismo, en un ejercicio de imputación objetiva que permite determinar si el daño es o no atribuible al municipio demandado. En otros términos, si bien se desconoce la causa que dio origen a la lamentable muerte de Jhon Alexander Marín Moncada, lo que prima facie, desde el plano material, configuraría una ausencia de imputación respecto del Estado, lo cierto es que desde la perspectiva del derecho, el estudio de la misma enseña que ésta no sólo puede ser fáctica, sino también normativa, que, para el caso, se estructura en la dimensión de la imputación objetiva y, concretamente, de la omisión. En consecuencia, el hecho de que el daño tenga su génesis directa, material y causal en una acción ajena a la administración pública no quiere significar, en principio, que se haya configurado una causa extraña que exonere de responsabilidad, toda vez que aquél puede devenir imputable a esta última si su comportamiento fue relevante y determinante en el desencadenamiento del mismo, bien porque se contribuyó con una acción en la producción ( $v$. gr., con un aumento del riesgo permitido o un desconocimiento del principio de confianza), o si pudiendo evitarlo se abstuvo de enervar su generación, esto último, siempre y cuando se constate en estos eventos que la entidad demandada se encontraba en posición de garante, es decir, que de conformidad con el ordenamiento jurídico estuviera compelida a evitar el resultado. Por consiguiente, si bien la imputación fáctica tiene un sustrato material o causal, lo cierto es que no se agota allí, ya que dada su vinculación con ingredientes normativos es posible que en sede de su configuración se establezca que un daño en el plano material sea producto de una acción u omisión de un tercero o de la propia víctima, pero resulte imputable al demandado siempre que se constate la ocurrencia de cualquiera de los siguientes aspectos: i) con fundamento en el ordenamiento jurídico se tenía el deber de impedir la materialización del daño (posición de garante); ii) con su actividad se incrementó el riesgo permitido (creación de un riesgo jurídicamente desaprobado); o iii) se estaba dentro del ámbito de protección de una norma de cuidado"(Consejo de Estado, sentencia del 9 de junio de 2010). También, en sentencia del 5 de julio de 2012, el máximo tribunal contencioso administrativo imputó un resultado a partir de esta teoría. En ese sentido, reflexionó: "La imputación fáctica tiene como propósito determinar si en el plano material, mas no necesariamente causal, el daño es atribuible o no a un sujeto de derecho. Así las cosas, antes de abordar el análisis de la imputación jurídica o el fundamento de la responsabilidad, es imprescindible que la lesión o afectación antijurídica esté radicada en cabeza de la entidad o del sujeto pasivo de la relación. Una vez constatado lo anterior, es posible abordar el análisis sobre la imputación jurídica, esto es, si existe o no un fundamento normativo que concrete, en el caso específico, la obligación de resarcir el daño
\end{abstract}


Se evidencia en la jurisprudencia contencioso-administrativa que, a diferencia de lo aquí propuesto, el resultado, en sede imputación de derecho, ha desarrollado un conjunto de instrumentos para su atribución, entre los que se encuentran “i) el riesgo permitido; ii) el principio de confianza; iii) la posición de garante; iv) la acción a propio riesgo; v) la prohibición de regreso y vi) el fin de protección de la norma”, así el criterio de la adecuación, que en este trabajo se señala como el ideal para imputatio iuris, no es abordado en materia de responsabilidad del Estado.

De esta forma, para que el Estado sea responsable, no es necesario que su actuación, desde una prognosis póstuma, tenga como resultado normal o probable la causación del daño. Por lo que, en últimas, a partir de los títulos de imputación utilizados por el Consejo de Estado, la responsabilidad de este, desde la óptica de la relación causal, entendida como atribuibilidad del daño, es mucho más amplia de lo que sería de aplicar los predicamentos que en este texto se exponen.

Con todo, si bien esta teoría, a partir de la diferenciación entre una causa fáctica y una jurídica, logra superar gran parte de los inconvenientes que se presentaban en el pasado al utilizar los diferentes instrumentos teóricos que no contenían esta dualidad, lo cierto es que persisten aún problemas relevantes. Se le reprocha a la imputación objetiva "que no explique adecuadamente los casos de causalidad hipotética y alternativa, en este caso además hay un criterio de exclusión de imputación que puede agravar este último problema, a saber: el criterio del incremento del riesgo o de la conducta alternativa correcta"(Ortiz Gómez, 2010, p. 332).

\subsubsection{Problemas de sobredeterminación e incertidumbre causal}

Ahora bien, a pesar de las bondades propias de la distinción entre causalidad de hecho y causalidad de derecho, lo cierto es que subsisten algunas puntuales hipótesis que pueden representar casos problemáticos a la hora de dilucidar el vínculo de causalidad. Estas hipótesis, en general, se refieren a situaciones en las que el test sine qua non y los juicios contrafácticos resultan insuficientes

antijurídico En otros términos, la imputación fáctica —y con ella la imputación objetiva del daño— consiste en un estudio retrospectivo que recae sobre la acción u omisión del sujeto, mientras que la imputación jurídica supone la realización de un análisis prospectivo y netamente normativo dirigido a determinar si, una vez establecida la atribución material del daño, existe o no el deber jurídico — subjetivo u objetivode resarcir el perjuicio"(Consejo de Estado, sentencia del 5 de julio de 2012). 
para esclarecer, desde la perspectiva física o natural, si un fenómeno fue el detonante de otro.

Piénsese, por ejemplo, en el caso en que tres sujetos (B1, B2 y B3) disparan un arma de fuego en un campo de caza, hiriendo una de las balas a un deportista que corría por el sector, pero sin que se sepa, a ciencia cierta, cuál de los tres cazadores fue el que propinó la herida. En una situación como esta, se tiene una pluralidad de actividades, cada una de las cuales era suficiente para generar, por sí sola, la totalidad del daño, aun cuando no se sabe realmente cuál fue la que efectivamente lo irrogó.

$\mathrm{Al}$ aplicarse el test sine qua non, se observa entonces que no es posible determinar en ausencia de cuál actividad — si la de B1, B2 o B3— se habría podido evitar la lesión y, de contera, tampoco se puede esclarecer quién es el causante fáctico de esta. Dicho tipo de inconvenientes han aflorado en la práctica y han conducido a adoptar cierto tipo de soluciones normativas que procuran evitar que, en estos casos, se llegue a la paladina injusticia de dejar a la víctima sin indemnización por la imposibilidad de acreditar la relación causal.

Pues bien, en este acápite, se tratarán dos de estos aspectos problemáticos: el de la denominada sobredeterminación causal y el de la causalidad incierta - $\mathrm{O}$ los problemas de causalidad alternativa- ${ }^{39}$ en aras de plantear un modelo de solución que también fue ya desarrollado por el derecho europeo y que, al parecer, es el criterio más difundido entre los comparatistas que se han dedicado a la cuestión.

\subsubsection{El problema de la sobredeterminación causal}

La sobredeterminación causal se presenta, esencialmente, cuando, existiendo una pluralidad de actividades, cada una de ellas habría podido causar el daño por sí sola al mismo tiempo. En este caso, “... la regla de la conditio [test sine qua non] no resuelve el problema porque daría lugar al resultado absurdo de que ninguna actividad puede haber sido la causa porque el daño igualmente se hubiera producido como resultado de la otra u otras actividades" (Martín Casals, 2011, p. 2). Ciertamente, si cada una de las actividades separadas y

\footnotetext{
${ }^{39} \mathrm{Al}$ respecto, Martín Casals pone de presente que la "idea contrafactual que está en la base de la conditio sine qua non no resuelve el problema de establecer si una actividad ha sido la causa de un daño ni en casos de sobredeterminación, como cuando existe causalidad concurrente, ni en casos de incertidumbre" (2011a, p. 1).
} 
autónomas hubiera sido suficiente, por sí sola, para la generación del daño, lo cierto es que la pregunta del juicio sine qua non sería siempre negativa: no se puede asegurar que, al eliminar alguna de las actividades, habría desaparecido el resultado, comoquiera que, en cualquier caso, subsistían otras que lo podrían generar.

Piénsese, por ejemplo, en el caso en que A dispara un misil de corta distancia, mientras que $\mathrm{B}$ dispara uno de larga distancia, y los dos misiles impactan el objetivo exactamente al mismo tiempo. En esta hipótesis, si se aplicara la regla de la conditio sine qua non, que proponemos para la verificación de la causalidad de hecho, se tendría que ni A ni B pueden considerarse como agentes causales del daño. En efecto, en el caso de A, es evidente que, aun omitiendo su proceder, subsiste el daño irrogado — en virtud del misil lanzado por $\mathrm{B}$-, de modo tal que él no es causa de este de acuerdo con la teoría del juicio contrafáctico. Idéntica es la situación de B: incluso si él no incurriera en la conducta, el resultado subsistiría — dado el disparo de A-, por lo que él no podría ser considerado como detonante de este.

Así, la sobredeterminación llevaría entonces a un absurdo: a pesar de que los dos misiles impactaron en el objetivo, al haberlo hecho al tiempo $-y$ es importante enfatizar en que la sobredeterminación requiere que los resultados se produzcan al tiempo-, el test sine qua non llevaría a considerar que la víctima no tiene derecho a la indemnización, porque ni $\mathrm{A}$ ni $\mathrm{B}$ pueden ser considerados como causa fáctica del daño. Naturalmente, esta es una respuesta contraintuitiva.

Para solucionarlo, hace falta adoptar una previsión normativa de cómo solucionar el problema causal que se presenta. Por eso es por lo que los instrumentos comparados lo que suelen hacer es matizar la regla sine qua non para los casos de sobredeterminación y establecer que, en estos, todos los intervinientes serán considerados como causa de la lesión. Así se evita llegar al resultado absurdo antes mencionado. En ese sentido, es ilustrativo el artículo 3:102 de los Principios de Derecho Europeo de la Responsabilidad Civil, que, en relación con las causas concurrentes (o sobredeterminación causal), establece que "en caso de una pluralidad de actividades, si cada una de ellas hubiera causado el daño por sí sola al mismo tiempo, se considerará que cada 
actividad es causa del daño de la víctima”. ${ }^{40}$ Del mismo modo lo hace el Restatement norteamericano, que aconseja adoptar esta previsión.

De esta forma se supera el escollo de la sobredeterminación a favor de la víctima, pues, contrario al resultado que se lograría inicialmente de librar a todos de responsabilidad a partir del juicio contrafáctico, la solución por la que se opta es la de tener a todos los agentes como causantes del daño, generando responsabilidad en cabeza de todos de manera solidaria. ${ }^{41}$ Así, la víctima podrá accionar en contra de cualquiera de ellos para pedir la indemnización a la que tiene derecho de acuerdo con el daño que ha sufrido, sin que pueda alegar el demando el hecho de los demás para librarse de su responsabilidad. ${ }^{42}$

Para concluir, vale la pena resaltar dos aspectos adicionales: en primer lugar, para que se presente realmente el problema de la sobredeterminación causal, es preciso que cada actividad haya sido capaz de generar el daño al mismo tiempo. Si una lo genera primero y la otra lo hace después, será evidente que el juicio contrafáctico o test sine qua non resolverá el problema, comoquiera que será solamente el primer hecho dañoso el que se considerará como causa.

De otra parte, no se puede confundir la sobredeterminación con el problema de incertidumbre causal, que se explicará en el acápite siguiente. A diferencia de este, en el caso de la sobredeterminación existe certeza sobre la

\footnotetext{
${ }^{40}$ Sobre esta solución, el profesor Jourdain expresa: "Lorsque des activités indépendantes prises isolément auraient, dans le même temps, suffi à causer le même dommage, les PETL décident que chacune des causes dites 'concurrentes' doit être retenue comme cause du dommage. Cette solution qui est conforme à notre jurisprudence, mais aussi à celles des autres systèmes juridiques, prend ses distances avec le test de la condition sine qua non car en l'absence l'une ou l'autre activité le dommage se serait quand même produit; mais la dérogation est nécessaire car à défaut aucune cause ne serait retenue" (2014).

${ }^{41} \mathrm{Tal}$ solución se encuentra en el derecho colombiano en el artículo 2344 del Código Civil: "Si un delito o culpa ha sido cometido por dos o más personas, cada una de ellas será solidariamente responsable de todo perjuicio procedente del mismo delito o culpa, $[\ldots]$ ”. Jorge Baraona González afirma que, en los casos de pluralidad de autores de un daño indemnizable, "los tribunales franceses tienden a condenar in solidum, sin perjuicio de las excepciones legales. Como presupuesto básico se exige que el daño debe ser único y provenir de diversas personas que convergen en un solo daño, sin importar si la culpa de los responsables es concurrente o sucesiva" (2004, p. 221).

${ }^{42}$ Señala la profesora Múrtula que "en estos casos, en la medida en que se puede eliminar mentalmente cualquiera de los factores sin que se altere el resultado, éste resulta imputable a todos. Aunque podría argumentarse que en ausencia del hecho individual de cada partícipe la consecuencia hubiera igualmente acaecido, esto no es admisible como defensa, pues si así fuese al invocarla cada uno o ninguno sería responsable del perjuicio" $(2005$, p. 68).
} 
entidad de cada una de las causas para provocar el daño y es por la concurrencia temporal (por generar la consecuencia perjudicial al mismo tiempo) que se les reconoce a todas como causas en las mismas condiciones. ${ }^{43}$ Aquí el problema no es, en estricto sentido, que no se sabe a ciencia cierta qué conducta causó el daño; no: aquí es claro que ambas conductas lo causaron, lo que sucede es que, al hacerlo al mismo tiempo, el test sine qua non no puede esclarecer cuál es el detonante del resultado final.

\subsubsection{El problema de la incertidumbre causal}

El segundo grupo de casos problemáticos tiene que ver con la denominada incertidumbre causal. Bajo este rótulo se agrupa toda suerte de hipótesis en las que no se puede determinar, con la suficiente certidumbre, quién fue el agente causante del daño. Puesto en otros términos, se trata de situaciones en las que no se sabe a quién imputarle fácticamente el resultado, porque no se puede, desde el punto de vista epistemológico, determinar de dónde provino el resultado.

Es importante señalar que la incertidumbre a la que se hace referencia en este punto no es a la incertidumbre epistemológica o evidenciaria, esto es, a la resultante de la imposibilidad de probar quién ha sido el causante del daño. En estos casos, la incertidumbre es indeterminista u ontológica, es decir, no se refiere a la imposibilidad de probar, sino a la imposibilidad objetiva de saber quién fue el detonante causal. Así las cosas, los ejemplos que se citan a continuación no se refieren a casos de dificultad probatoria, sino a situaciones en las que es imposible, fácticamente hablando, determinar qué acción constituye la causa del daño.

Pues bien, varias situaciones encajan en este tipo de supuestos, a saber:

La denominada causalidad alternativa con incertidumbre de agente o causante del daño no identificado, "que se produce cuando nos encontramos ante diversos hechos que, aunque poseen individualmente aptitud para producir un daño, éste ha sido obra exclusiva de uno solo de los partícipes. El hecho dañoso

\footnotetext{
${ }^{43}$ En los comentarios a este artículo en los Principios de Derecho Europeo de la Responsabilidad Civil, se destaca "que es irrelevante si las actividades tuvieron lugar al mismo tiempo o no; lo decisivo es que causaron el daño al mismo tiempo. Ello puede mostrarse mediante un ejemplo algo rocambolesco. D1 lanza un misil de larga distancia y D2 uno de corta distancia. Ambos misiles impactan con las instalaciones de $\mathrm{P}$ al mismo tiempo. El lanzamiento no tuvo lugar al mismo tiempo, mientras que los misiles alcanzan su objetivo exactamente al mismo tiempo. Lo decisivo es esto último"(Spier, 2012, pp.79 y ss.).
} 
aparece atribuible a uno u otra persona dentro de un conjunto de ellas de manera excluyente..." (Múrtula, 2005, p. 69), pero no es posible determinar, a ciencia cierta, a quién se le puede atribuir.

Puesto en otros términos, es una hipótesis que se presenta cuando, en el caso de una pluralidad de actividades, cada una de ellas ha sido suficiente, por sí sola, para causar el daño, pero es dudoso cuál fue la que efectivamente lo causó, es decir, se sabe que solamente una actividad tenía la aptitud para detonar el perjuicio reclamado, pero, dentro del conjunto de actividades existentes, no se sabe exactamente cuál fue la que lo hizo.

Piénsese en el caso expuesto más arriba: B1, B2 y B3 van de caza al bosque y, de manera independiente el uno del otro, disparan simultáneamente sus armas de fuego, apuntando en la misma dirección. Uno de los disparos hiere a un transeúnte del sector $(\mathrm{A})$, mientras que los otros dos no le alcanzan. No es posible determinar si el disparo que ha impactado en $\mathrm{A}$ fue el realizado por B1, B2 o B3, pero se sabe con claridad que fue el de alguno de estos tres.

En este caso se presenta una hipótesis de típica incertidumbre causal. Un juicio de responsabilidad no permitiría saber a quién atribuirle la obligación de indemnizar, habida cuenta del problema antes descrito.

Un segundo caso es el de la causalidad alternativa con incertidumbre en la relación entre causantes y víctimas, que se presenta cuando existe una pluralidad de causantes del daño y una pluralidad de víctimas, sin que sea posible determinar qué agente le ha causado el daño a qué víctima, aun cuando es claro que no ha sido uno de los agentes el que le ha causado el daño a todas las víctimas. ${ }^{44}$

Un caso puede ilustrarlo mejor: supóngase que cuatro farmaceutas (B1, B2, B3 y B4) han producido un medicamento defectuoso. B1 tiene una cuota del mercado del $70 \%$, mientras que los restantes tienen, cada uno, una cuota del $10 \%$. El medicamento produce daños a cien personas, sin que sea posible establecer de qué farmaceuta es el medicamento que ha adquirido cada uno de los cien afectados, aun cuando sí se sabe que no provenían todos de un mismo farmaceuta.

${ }^{44}$ Dicho de otro modo, en este caso existe "una pluralidad de causantes de daños (D1-D10) y una pluralidad de víctimas (P1-P100), pero se ignora qué causante (D) ha causado el daño a qué víctima (P)" (Martín Casals, 2011, p. 3). 
Una vez más, en cada una de las acciones elevadas por cada una de las víctimas, no será posible entonces establecer a quién se debe demandar, en la medida en que no existirá certeza sobre si su agente causal ha sido B1, B2, B3 o B4. Estos casos de incertidumbre causal son también conocidos como casos de cuota de mercado o 'market share liability', y se han difundido últimamente por cuenta de los daños irrogados por los productos confeccionados en masa.

$\mathrm{El}$ tercer supuesto de incertidumbre causal es el que se conoce como el caso de victimas no identificadas. Aquí lo que sucede es que

[...] existe un agente, como la contaminación emitida por una fábrica, el principio activo de un medicamento u otro factor procedente de una fuente de riesgo similar, que incrementa el número de casos de personas que sufren una determinada enfermedad originada por factores independientes de la responsabilidad de alguien. Sabemos que hay más víctimas que antes pero no podemos saber cuáles son las víctimas que deben su dolencia a la contaminación de la fábrica. Es el caso, por ejemplo, en el que " $\mathrm{D}$, una fábrica altamente contaminante se instala cerca de una gran ciudad en la que se producían 20 casos de cáncer al año, y lanza a la atmósfera emisiones cancerígenas no permitidas por la ley. A los cinco años de su instalación, se ha constatado que el número de casos de cáncer se ha ido incrementado de año en año y ya es de 100 . P1, P2 y P3, habitantes de esa ciudad, acuden al médico, quien les diagnostica un cáncer terminal, por lo que deciden presentar una demanda de responsabilidad civil contra la fábrica $\mathrm{D}$ por la enfermedad que sufren". Aunque, en estricto sentido, no se sabe si su cáncer es producto del riesgo ya existente con anterioridad o del incremento de casos que ha propiciado la fábrica. En fin, se encuentran los casos de incremento de riesgo. "[...] a diferencia de los casos en que se sabía que el daño de una víctima había sido causado por un ilícito civil de un miembro de un grupo de 'sospechosos' a los que pertenecía el demandado — casos (a) y (b) - o que el demandado había causado ilícitamente un daño a un grupo al que pertenece el demandante - caso (c) -, esta categoría incluiría los casos en los que la incertidumbre se refiere a si un solo agente demandado (D) ha causado un daño a un solo demandante (P)". Un ejemplo lo ilustra mejor: "P nace con un grave daño cerebral. Se ignora si el daño ha sido el resultado inevitable de su nacimiento prematuro o 
ha sido causado por el tratamiento negligente del doctor D. Se establece que la probabilidad de que el daño haya sido causado por tratamiento erróneo es del 30\%" (Martín Casals, 2011, p. 3).

Nótese entonces cómo, en cualquiera de las anteriores hipótesis (a, b, c o d), lo que existe es un problema de incertidumbre causal, en el sentido de que no se puede determinar, a ciencia cierta, quién ha sido el detonante causal del daño. Frente a ella, se han adoptado dos tipos de soluciones, como se explica a continuación.

Una de ellas tiene que ver con la aplicación de la regla conocida como del "todo o nada" y la regla de la "indivisibilidad de la causa del daño". Expone Juan Manuel Prevot que

durante largo tiempo se exigió que el daño sea corolario ineluctable, directo y único de la conducta del sujeto endilgado responsable. Si bien con el transcurso del tiempo el derecho suavizó paulatinamente esta exigencia, aún perduran resabios de la misma, como, por ejemplo, la fórmula optativa del "todo o nada".

Este vetusto modo de razonar se asienta sobre dos pilares fundamentales: 1) la regla de la "indivisibilidad de la causa del daño" y 2) la exigencia de que el nexo causal sea demostrado en forma indubitable, es decir, con 'certeza absoluta'.

Como consecuencia de ello, en todos los casos en que no se logre probar fehacientemente 'el cómo y el porqué del perjuicio sufrido, esto es, mientras no surja con palmaria claridad la relación de causalidad entre la conducta del accionado y el daño reclamado por el pretensor, el reclamo indemnizatorio debe ser rechazado (Prevot, 2010, p. 151).

Puesto en otros términos, la regla del "todo o nada" exige que el grado de convicción sobre la existencia del vínculo causal sea rayano con la certeza. Cualquier resquicio de duda o de poca claridad dará al traste con la pretensión de indemnización, por ausencia de uno de los elementos estructurales de la responsabilidad.

Como es obvio, si se adopta un sistema de este tipo, el resultado al que se arriba es a que en los mencionados casos de incertidumbre causal, ante la falta de un medio probatorio que otorgue la certeza necesaria de que uno de 
los sindicados como agentes dañadores fue el causante del daño, de acuerdo con el umbral de convencimiento requerido, su pretensión indemnizatoria será desestimada, pues la alternatividad de agentes no es permitida bajo esta teoría. Los casos de causalidad incierta, por definición, son opuestos a la certeza, por lo que, bajo la regla de "todo o nada", son casos en los que no surgirá la obligación de indemnizar por ausencia de uno de los presupuestos estructurales de la responsabilidad.

Ahora bien, se le denomina regla de "todo o nada" por cuanto no admite puntos medios: o la pretensión prospera como un todo o no prospera; no hay matices; o gana el demandante o gana el demandado, según el umbral de certeza que se alcance respecto de la causalidad.

La cuestión es que una solución así puede no ser la más equitativa, comoquiera que

afirmar que, como no se puede determinar quién es el causante del daño, ninguno de los miembros de ese conjunto de personas debe responder, porque el artículo 1902 del Código Civil [análogo del artículo 2341 de la codificación colombiana] —pieza de toque de nuestro sistema de responsabilidad - exige la existencia de un nexo de causalidad entre el acto generador de responsabilidad y su autor físico, no parece que sea la solución más justa; pues llegaríamos a la paradoja de encontrarnos que la víctima de los daños causados por un individuo no determinado dentro de un grupo no tiene derecho a ser resarcida, pero sí lo tiene cuando puede identificar a su autor. Se trataría de supuestos conocidos por la doctrina como casos de causalidad alternativa, de 'culpa anónima', de causalidad incierta o 'causa anónima', que de no ser indemnizables frustrarían la finalidad del derecho de daños (Múrtula, 2006, p. 3).

La regla del "todo o nada" se la juega entonces por la justicia o la injusticia total, $y$, de hecho, suele colindar con esta última, porque en casos como el de la incertidumbre de agente o de relación agente-víctima, en los que se sabe que alguien ha generado el daño, pero no se sabe quién, opta por dejar a la víctima sin indemnización y, de contera, por permitir la fuga de la responsabilidad. La falta de certeza en relación con la identidad específica del agente causante del daño - independientemente de la certeza en cuanto a su causación — conduce 
a un resultado injusto y contraintuitivo: la víctima, a pesar de que padeció un perjuicio y de que es sabido que alguien se lo generó (aun cuando no se sabe quién), quedará desprovista de indemnización y su daño quedará en el aire.

La contracara, como es obvio, es que se evita así la condena de un inocente; ciertamente, al no proferir un fallo de responsabilidad, evita condenar a un sujeto que, de repente, nada tuvo que ver con el ilícito civil (por ejemplo, condenar a uno de los cazadores que no le dio a la víctima).

El problema, sin embargo, es que, como lo decíamos, esta solución enfrenta un riesgo potencial de injusticia muy alto: al no admitir un camino intermedio, lleva a que un sujeto gane todo, mientras que el otro lo pierda, lo que es contrario a ciertos principios morales que subyacen a los sistemas jurídicos de occidente, como el de equidad. Además, es una situación que genera incentivos distorsivos, comoquiera que favorece el que se adopten prácticas en las que, de consuno, los potenciales dañadores fomenten los daños anónimos, para eludir así su responsabilidad.

Pues bien, para evitar esta 'fuga de responsabilidades' en los casos de incertidumbre causal, instrumentos de derecho comparado han adoptado el criterio de la distribución proporcional en materia causal. Se trata de abrir un espacio a soluciones intermedias en las que no se juega el "todo o nada" en el juicio de causalidad, sino que se admite una condena proporcional en los casos en que existe solamente una probabilidad de que el sujeto fuera el agente causal del daño. Naturalmente, la proporción en que cada uno será condenado dependerá, en estricto sentido, de la probabilidad de que haya sido el causante del daño.

Se evita entonces de este modo que, en casos como los de la incertidumbre causal, se llegue a la absoluta exoneración de los demandados y, de contera, a la exclusión de la víctima de toda indemnización. Por el contrario, esta última podrá reclamar de cada potencial dañador la cuota que le corresponda de acuerdo con la probabilidad estadística de que fuera el causante del daño.

Una solución como la propuesta no solamente luce más equitativa — en la medida en que no deshace la pretensión de la víctima en las hipótesis en que es epistemológicamente imposible acreditar la causalidad—, sino que, además, fomenta el principio de solidaridad, comoquiera que asigna la obligación de indemnizar a los potenciales causantes, cuando estos han decidido intervenir en una determinada actividad. 
No en vano los Principios de Derecho Europeo de la Responsabilidad Civil (artículo 3:103)

proponen como solución general la denominada causalidad proporcional, es decir, una distribución del daño en proporción a la probabilidad de haberlo causado. La regla requiere que concurran los demás fundamentos de la responsabilidad (p. ej., actuación culposa o actividad que daría lugar a responsabilidad objetiva, existencia de daño resarcible, etc.) pero partiendo de que ha existido un riesgo que, en términos generales, es apto para producir el tipo de daño del que se trate, propugna por establecer la responsabilidad en función de la probabilidad de que el riesgo que ha creado el agente haya podido causar el concreto daño sufrido por la víctima (2011, p. 2).

De esta forma se busca dar lugar a soluciones más equitativas, modulando el problema al que se ve expuesta la víctima cuando se enfrenta a la regla de "todo o nada", que, como se expuso, para la prosperidad de la pretensión indemnizatoria supone llevar al juzgador a un convencimiento más allá de cierto umbral de certeza sobre la causación del daño. ${ }^{45}$ Bajo el espectro de la fórmula propuesta, la víctima tendrá que probar el grado de probabilidad de que dicho agente sea el causante del daño, para que, a partir de ese hecho probado, el juez asigne la reparación conforme a esa estadística, sin que sea necesario un umbral mínimo al respecto.

Explica Miquel Martín Casals que, además,

la responsabilidad proporcional también intenta distribuir de una manera más equitativa los riesgos de la insolvencia. La responsabilidad por cuota del mercado, por ejemplo, parte de la idea de que cuando hay una pluralidad de fabricantes posibles causantes del daño (D1-D10) y una pluralidad de víctimas (P1-P100), y se sabe que el causante D1 no puede haber causado el daño de todas las víctimas,

\footnotetext{
${ }^{45}$ Steven Shavell indica: "In many situations there is uncertainty about causation. For example, it may not be known which manufacturer out of many sold the product that resulted in injury, or whether harm was due to the defendant firm's pollution or to background factors. The traditional approach of the law is to employ a $50 \%$ probability threshold: to hold a defendant liable if and only if the probability that the defendant was the cause of losses exceeds 50\%. More generally, the courts could employ a probability threshold t different from 50\%" (Polinsky y Shavell, 2007, pp. 162-163).
} 
no parecería justo hacerle responder del daño de todas las víctimas o de una parte sustancial de ellas simplemente por el hecho de que los otros fabricantes han dejado de operar en el mercado o son insolventes, ya que se le haría responder por un daño que se sabe a ciencia cierta que no ha causado $(2011$, p. 2).

Esto luce aún más razonable en casos en los que se trata de la distribución de productos en el mercado o del incremento de riesgos en la sociedad, como consecuencia de una actividad productiva. En estos casos, quienes intervienen en el mercado o en la actividad obtienen un provecho derivado de esta, por lo que se acompasa con las reglas de solidaridad social que, en casos de incertidumbre causal o de daños anónimos, en lugar de dejar desprotegidas a las víctimas, asuman una cuota proporcional en la causalidad, de acuerdo con la probabilidad de haber inferido el perjuicio.

Finalmente, es de resaltar que, desde la perspectiva del análisis económico del derecho, resulta más eficiente este esquema de imputación de la obligación reparatoria, a través de la probabilidad. Bajo el sistema de la regla "todo o nada", el sujeto dañador que sepa que la probabilidad de que él sea el causante del daño es menor al 80\% (que, como se mencionó, es el umbral de certeza exigido en el derecho norteamericano) nunca será responsable y por lo mismo no tendrá ningún incentivo de reducir su riesgo, dando lugar a resultados subóptimos. Por el contrario, en la medida en que bajo la regla que se propone la responsabilidad corresponda exactamente a la probabilidad de que sea el agente dañador, existe un incentivo para disminuir el riesgo y adoptar conductas más seguras, tal como si no existiera la incertidumbre sobre la causalidad.

Se evidencia cómo estas soluciones proporcionan respuestas idóneas a los problemas que la teoría de la imputación objetiva no logra solventar. Así, se construye un entramado normativo completo, con capacidad de brindarles a los diferentes interesados en la determinación causal y la imputación de un daño los instrumentos necesarios para adelantar este juicio con el mejor criterio.

\subsection{La aplicación de las soluciones propuestas en el escenario específico de la responsabilidad ambiental}

Las circunstancias en las que se configura el perjuicio ambiental, así como la envergadura de este desde el punto de vista de las víctimas y los victimarios, complejizan enormemente el análisis de la relación causa-consecuencia. 
Ciertamente, cuando a la complejidad ordinaria de la causalidad se le suma un escenario en el que la mayoría de hipótesis revelan causas concurrentes, daños anónimos y contribuciones leves, la dificultad crece exponencialmente. Habida cuenta de esta realidad, que afecta a los litigios existentes en esta materia, hoy en día se han presentado revolucionarias tendencias que matizan o morigeran el alcance de los principios tradicionales de la causalidad. ${ }^{46}$ Efectivamente, si bien el análisis preponderante aún se rige por el tradicional criterio de la causalidad adecuada, el de la responsabilidad ambiental ha sido un prolífero escenario para revelar las dehiscencias de estos parámetros y proponer doctrinas de avanzada que están ad portas de aplicarse en sede judicial, como las que se expusieron ya en párrafos precedentes y como sucintamente se reseña a continuación.

\subsubsection{La causalidad probable y las presunciones de causalidad}

El primer problema que se presenta en el escenario de la responsabilidad ambiental tiene que ver con la certeza de la causalidad. En efecto, las características particulares de esta modalidad de responsabilidad impiden, las más de las veces, conocer a ciencia cierta cuál fue la causa que desató una situación de alteración ambiental. Como es obvio, en los fenómenos naturales inciden

\footnotetext{
${ }^{46}$ Como lo asevera la doctrina, “... en materia de responsabilidad por daños al medio ambiente, la existencia o comprobación de este nexo de causalidad, cuando es exigido, es aún más difícil. La dificultad de su determinación en los daños producidos al medio ambiente es muy considerable. Es decir, muchas veces se da un mal criterio de imputación, ya que para el daño ambiental lo normal es que haya demasiadas causas determinantes del origen del suceso del daño..."(De Carvalho Leal, 2010, p. 168). El profesor Néstor Cafferatta, por su parte, explica que “... el daño ambiental contiene una problemática propia inherente a la cuestión medioambiental; cierto grado de 'incerteza' o 'incertidumbre'. Hace tiempo que, aun dentro del campo de las ciencias duras o de las ciencias de la naturaleza, se ha abandonado la idea del determinismo, de la relación de causalidad absoluta, de causalidad cierta e indubitable. A partir de la física cuántica, ha cambiado el concepto de la relación de causalidad y se ha incorporado el de azar, la estocástica. Ilia Prigogine, premio Nobel de Química en 1977, adquirió fama a nivel científico por haber incorporado al azar a la relación de causalidad.Él comenta que hemos pasado de una lógica de relación causal 'del reloj' a una lógica de relación causal 'de las nubes'. Asimismo, dice que la relación de causalidad en las ciencias de la naturaleza ha perdido el sentido lineal de causa-efecto, es decir, 'dada tal causa se produce tal efecto'. Para él, la relación de causalidad se ha transformado en una suerte de relación de causalidad circular, en virtud de la cual lo que era causa se transforma en efecto y lo que era efecto se transforma en causa. En consecuencia, si las ciencias físicas y las de la naturaleza nos están enseñando que hay que tener en cuenta elementos de incerteza, no hay razón por la cual en el ámbito de la responsabilidad por daños y, en particular, por daño ambiental, se exija una relación de causalidad absoluta, indubitable, lejos de la idea de la probabilidad"(Cafferatta, pp. 88-89).
} 
un sinnúmero de variables aleatorias que, en definitiva, impiden determinar, con relativo grado de certidumbre, la relación causa-consecuencia, incluso a la luz de postulados abstractos, que, como las máximas de la experiencia, son los indicados por la teoría de la causalidad adecuada, hoy en día imperante en materia civil. No en vano, las ciencias naturales abandonaron la renombrada teoría del determinismo.

Es, en suma, el problema de la incertidumbre causal que, con múltiples variantes (causalidad alternativa con incertidumbre en el agente, causalidad alternativa con incertidumbre en la relación agente-víctima, etc.), fue expuesto en el acápite precedente y que se materializa, fundamentalmente, cuando es objetivamente imposible determinar quién fue el causante de un determinado resultado dañoso.

La solución tradicional para estos casos es que, al no cumplirse con un determinado umbral de certeza en relación con la existencia de vínculo causal, se impone la necesidad de exonerar a todos los potenciales agentes dañadores y, de contera, privar de toda indemnización a la víctima. Así, por ejemplo, si se sabe que en una determinada región del territorio han surgido ciertos daños ambientales con ocasión del accionar de tres fábricas, pero no se sabe a ciencia cierta cuál de ellas es la que ha causado un daño en el predio específico de A, la solución ordinaria sería la de exonerar a las tres fábricas habida cuenta de la falta de certeza en relación con la existencia de relación de causalidad. La contrapartida de esta circunstancia es que A resultaría sin indemnización a pesar de que es evidente que su situación sobrevino como consecuencia del accionar de alguna de las tres empresas, lo que se traduce en una situación de injusticia, especialmente a la luz de la justicia correctiva. ¿Qué hacer entonces frente a ello?

Un primer grupo de soluciones, con fuerte presencia en el derecho comparado, ha sido el de flexibilizar y matizar la exigencia de un nexo de causalidad cierto entre la conducta imputable y el daño irrogado, comoquiera que, de mantenerse dicha exigencia, en muchas ocasiones fracasaría y se frustraría cualquier pretensión indemnizatoria en sede ambiental. Las alternativas han sido diversas: juicios de causalidad hipotética, suposiciones de causalidad, causa flexible, causa aparente, entre otras varias más.

Con todo, la tendencia mayoritaria ha abogado por dos soluciones de particular acogida, a saber: 
a) La imputación por causa probable: bajo esta tesitura, el intérprete entiende acreditada la causalidad cuando, a la luz de un examen objetivo, aparece que un comportamiento, además de idóneo para producir un resultado, fue probablemente el que, en el caso concreto, llevó a producirlo. Así, esta teoría combina dos grupos de factores: la idoneidad y la probabilidad de la causa, de manera tal que entiende configurada la causalidad cuando, en abstracto, el fenómeno cumple con el mencionado requisito de idoneidad y, en concreto, llena también la exigencia de probabilidad. En otras palabras, lo que se mira en esta tesis no es la existencia de una causa cierta, sino de una causa probable del hecho, midiendo la probabilidad de acuerdo con los postulados de idoneidad y probabilidad propiamente dicha. ${ }^{47} \mathrm{La}$ ventaja para la víctima es notable: no se le exige el encomiable y muy elaborado esfuerzo por acreditar causalidad en fenómenos ambientales, sino que le basta con llevar una cierta convicción al operador judicial, de tal suerte que este encuentre probable la causación, por ejemplo, por existir indicios suficientes o por ser razonable estimarlo así.

b) Las presunciones de causalidad: otra alternativa bastante recurrida consiste en presumir el nexo de causalidad. El efecto más importante de esta presunción, como es sabido, tiene que ver con el traslado de la carga de la prueba de la víctima al victimario. ${ }^{48}$ Por esa razón, resulta ser una estrategia muy idónea en aquellos casos en que es más fácil desvirtuar la causalidad que acreditarla. Este escenario supone entonces que a quien ha padecido un daño no le corresponderá

${ }^{47}$ Cfr. De Ángel Yágüez (2000, pp. 77 y ss.), de acuerdo con el cual, en varios ámbitos de la responsabilidad, existe "... hoy una tendencia considerable a afirmar que cuando sea imposible esperar certeza o exactitud en materia de relación de causalidad, el juez puede contentarse con la probabilidad de su existencia [...] será en ocasiones una probabilidad próxima a la certeza, o bastará en otros casos la alta probabilidad, o será suficiente contar una probabilidad de más del 50 por 100 (el principio more probable than not de la jurisprudencia norteamericana), pero en todo caso se aliviará de forma sensible la posición del demandante [...] no basta que un hecho pueda ser considerado sólo como una hipótesis posible. Entre los elementos de hecho alegados, el juez debe tener en cuenta los que le parecen más probables. Esto significa sobre todo que quien hace valer su derecho fundándose en la relación de causalidad natural entre un suceso y un daño no está obligado a demostrar esa relación con exactitud científica...”(Scartazzini, 1991, pp. 62-64). 227).

${ }^{48}$ Sobre el particular, ver Parra Quijano (2009, pp. 235-241) y Sentis Melendo (1979, pp. 144, 209, 
probar que dicho daño fue consecuencia de la conducta del victimario, sino que, por el contrario, será al demandado a quien le corresponderá probar su exoneración, esto es, la inexistencia de cualquier relación causal. La presunción, por lo demás, es una estrategia pro victimae, en la medida en que, independientemente del caso concreto, consagra una regla general a favor de quien ha padecido un daño, en el sentido de entender o presuponer configurado el nexo causaly, en esa medida, asignar la carga de probar quién resulta demandado o acusado en el proceso de responsabilidad.

Pues bien, estas dos alternativas, como se decía, han sido aplicadas en normativas foráneas, con no despreciables resultados prácticos. El problema, sin embargo, es que es una solución que puede conducir a un cuestionamiento importante de equidad: ¿por qué se matiza la exigencia de la causalidad a favor de quien ha padecido un perjuicio ambiental y no a favor de quien ha sufrido otra clase de perjuicios cuando estos también reflejan un problema de incertidumbre causal? ¿Qué acaso el perjuicio ambiental es más relevante, valedero o merece una mayor tutela que otros perjuicios de naturaleza singular? Dar una respuesta satisfactoria a estos interrogantes será sumamente dificultoso, especialmente si se tiene en cuenta que la relación de causalidad trasluce uno de los componentes moralizadores de la responsabilidad civil y, de contera, matizarla o flexibilizarla puede suponer una matización o flexibilización selectiva del componente moral de la responsabilidad para ciertos ámbitos específicos.

Por eso, debe procurarse una solución que traduzca una regla general y no una gabela particular para los casos ambientales: esa solución de estirpe general, que no conlleva la inequidad antes mencionada, es la de aceptar la regla de la proporcionalidad ya explicada en un segmento anterior. En efecto, si se supera la regla del "todo o nada" y se acepta que la imputación de responsabilidad debe hacerse bajo un esquema de probabilidad, en el que los umbrales o estándares de certeza exigidos son menores, es entonces evidente que se alcanza una regla general que, sin las inequidades de una aplicación casuista, da una respuesta satisfactoria a los casos en que parece injusto imputarle toda la responsabilidad a un solo agente dañador (porque no se sabe si ese agente fue el que causó el daño), pero también luce desproporcionado dejar sin ninguna indemnización a la víctima (comoquiera que se sabe que alguno de los agentes la dañó). 
Nótese cómo en el esquema propuesto no se trata de reducir el umbral de certeza que se exige en materia de causalidad para imputar la totalidad de la responsabilidad a uno solo de los potenciales causantes del daño, ya que eso es justamente lo que se critica por ser una inequidad propia del casuismo; no: de lo que se trata es de admitir la regla general de la causalidad proporcional en virtud de la cual, ante situaciones de incertidumbre causal (y no solo de incertidumbre causal en materia ambiental), es preciso que todos los potenciales causantes del daño respondan, pero lo hagan en proporción a criterios objetivos, como es, por ejemplo, el criterio de la probabilidad.

Así, se reitera, no se juega todo o nada a favor de la víctima o del agente dañador: no se condena a un solo agente por reducir el umbral de la causalidad, ni se priva de toda indemnización a la víctima, sino que esta última recibe una indemnización integral, solo que la recibe de cada uno de los potenciales causantes, en proporción a la probabilidad de que hayan podido causar el daño. Esta solución tiene las ventajas prácticas y de justicia a las que nos referimos en el segmento anterior.

\subsubsection{La concurrencia de contaminadores}

Otra de las hipótesis que se puede presentar en materia medioambiental es la relacionada con la concurrencia de agentes causantes del daño. En principio, en estos casos, se aplicará el artículo 2344 del Código Civil colombiano y, en esa medida, tales agentes serán solidariamente responsables por los daños irrogados, sin perjuicio de las posteriores acciones que, internamente, puedan ejercer. ${ }^{49}$

Con todo, la dificultad se presenta cuando ninguno de los agentes, individualmente considerado, habría tenido la entidad suficiente para generar el daño. En estos casos, se pregunta entonces si pueden ser condenados a indemnizar, in solidum, el perjuicio irrogado, ya que, causalmente hablando, ninguna de sus contribuciones era conditio sine qua non para llevar al resultado lesivo. Nuevamente, surgen diferentes teorías. Una de las más aconsejables y acogidas parece ser adoptar una posición que, con fundamento en la guarda colectiva del ambiente, entienda que, al quebrantarse dicha guarda por una pluralidad

\footnotetext{
${ }^{49}$ Como bien lo ha indicado la jurisprudencia, “... según el artículo 2344, cuando dos o más personas incurren en un mismo hecho ilícito responden solidariamente, así se trate de hechos instantáneos o de extensa duración. Lo que interesa para los efectos de la solidaridad no es el proceso mismo causante del daño, sino su resultado [...]"(Corte Suprema de Justicia, sentencia del 30 de abril de 1976). Cfr. sentencia del 6 de agosto de 1985. Ver, también, Valencia Zea (1950, p. 250).
} 
de contaminadores, todos ellos están llamados a indemnizar, independientemente de que su contribución causal, por sí sola, no pudiera generar el efecto indeseado. Esta posición procura salvaguardar y tutelar efectivamente el ambiente sano, a pesar de que, en ocasiones, parezca excesivo o desproporcionado.

Esta ha sido la solución adoptada por la doctrina, a cuyo juicio

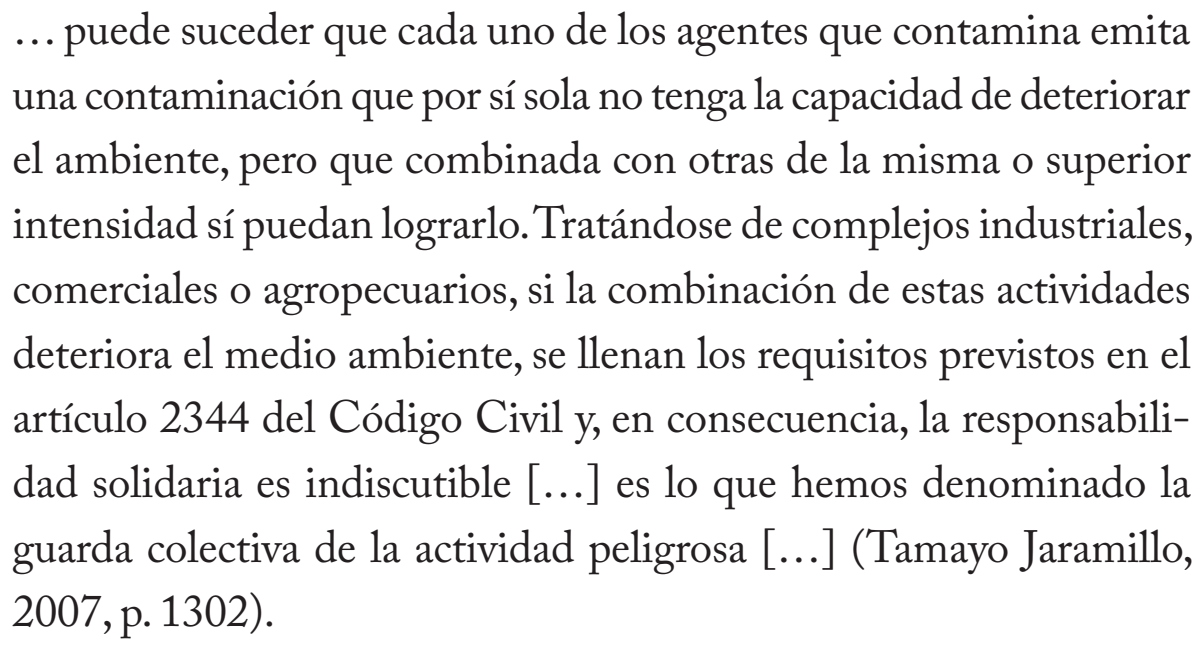

Con todo, esta solución genera los mismos inconvenientes que la aplicación irrestricta de la regla "todo o nada". Ciertamente, le impone la totalidad de la indemnización a un sujeto que, a ciencia cierta, ha sido condición necesaria pero no suficiente para la causación del daño. De este modo, conduce a una solución que desde la perspectiva de la justicia correctiva tampoco parece ser la más razonable; si la acción u omisión del sujeto no era, por sí sola, suficiente para lograr el resultado, no parece ser lo más justo que, en cualquier caso, se le condene al pago de la totalidad de la indemnización. De ahí que una regla proporcional, que considere la contribución causal del sujeto, parezca satisfacer mejor las exigencias morales que subyacen a la responsabilidad civil, evitando los conflictos a los que conduce la aplicación de la regla del "todo o nada”, en los términos expuestos anteriormente.

\subsubsection{Los daños anónimos}

En fin, una tercera situación usualmente compleja tiene que ver con la imposibilidad de determinar o individualizar un agente causante del daño dentro de un grupo de posibles victimarios. En esta hipótesis, el intérprete entiende que existe una comunidad más o menos amplia de individuos potencialmente responsables, pero no puede dilucidar, en forma cierta, cuál de ellos dio inicio al curso causal que desembocó en el perjuicio. Se trata entonces de casos de 
daños anónimos o de autor desconocido, vicisitud esta última que, como es natural, dificulta enormemente la imputación de responsabilidad.

Sin embargo, en aras de no sumir en un estado de ostensible desprotección a las víctimas, los sistemas de responsabilidad ambiental han acuñado también soluciones para circunstancias como las descritas. En general, en jurisdicciones como la anglosajona, se ha propuesto extender el principio de solidaridad a todos los individuos que potencialmente causaron el daño. Así, la víctima podrá requerir la indemnización de uno cualquiera de tales sujetos, independientemente de que, en la realidad, no se conoce, a ciencia cierta, quién irrogó la lesión.

Pues bien, esta es una nueva hipótesis en la que la regla de proporcionalidad parece brindar una solución justa que evita los problemas de la aplicación a rajatabla de una regla de "todo o nada". En virtud del sistema proporcional, se lograría que cada uno de los potenciales causantes del daño responda en proporción a la probabilidad de que haya causado el resultado, de modo tal que i) no se imponga la totalidad de la indemnización a un sujeto respecto del cual no se tiene certeza que haya causado el daño y ii) no se deje sin ninguna clase de reparación a la víctima del perjuicio cuando se sabe que esta ha padecido una lesión o menoscabo con ocasión de la situación. Esta situación es más deseable desde el punto de vista de la justicia y de la practicidad en los términos ya explicados en un acápite anterior.

\subsubsection{La labor del juez en el análisis de la causalidad}

Las anteriores reflexiones revelan que, en últimas, es al juez o al sentenciador a quien le corresponde ponderar los hechos de cada caso particular, con miras a determinar si existen o no suficientes circunstancias indicadoras de la relación causal. En este aspecto, como en los demás, no pueden sentarse reglas o cánones generales, comoquiera que la riqueza de los casos y, particularmente, de los hechos impone que el juzgador sea el llamado a determinar, cautelosa pero decididamente, si se cumplen los presupuestos de la causalidad. Para ello, debe fundarse en los criterios que provee el ordenamiento, pero también en la lógica, la intuición, la experiencia y la ciencia. ${ }^{50}$

\footnotetext{
${ }^{50}$ Como bien lo indica López Mesa, “... el juez a partir de la causalidad externa, física, demostrada, puede extremar su legítimo poder de análisis de las constancias de la causa, determinando sobre la base del
} 


\section{Conclusión}

Las consideraciones antes expuestas develan entonces el problema que existe actualmente con el vínculo causal y la necesidad de encontrar una fórmula que permita replantearlo. La sola dificultad que ofrece el nexo causal desde el punto de vista estrictamente físico o natural es ya un punto de partida suficiente para invitar a la continuidad de la revisión crítica y reflexiva sobre los criterios que son más adecuados en la práctica; del mismo modo, la experiencia comparada refleja que este es un aspecto que está lejos de ser acabado, por lo que es preciso que la academia y la jurisprudencia continúen su gestión en la construcción de teorías que sean lo suficientemente dinámicas como para compaginar con la variabilidad que ofrece la vida real.

Este escrito pretende sumarse al criterio doctrinal que se ha expuesto en la materia. Como se anunció en la introducción, en él se demostró que:

1) Las concepciones contemporáneas con las que se analiza a la relación de causalidad en el derecho colombiano resultan insuficientes y conducen, en varios casos, a soluciones irrazonables y contraintuitivas. Esto se hace especialmente patente en lo que tiene que ver con la teoría predominante, que es la denominada 'causalidad adecuada'. Al emplearse esta tesis como un criterio único de causalidad - y no como un examen de imputación que debe ser acometido justo después del estudio de la causalidad de hecho-, la causa adecuada se presta para que casos que, en justicia, debían conducir a una indemnización, aparejen realmente una exoneración. Eso es lo que sucede, por ejemplo, con las hipótesis de niños con cráneo 'cáscara de huevo' o, en general, en aquellas circunstancias en que el daño no cumple con criterios que parecieran pertenecer a otras esferas, como el de la previsibilidad.

2) Por esa razón se hace necesario repensar el esquema tradicional con el que se ha tratado la cuestión en el ordenamiento nacional. Tal vez la utilización de criterios como el de la adecuación, aunque deben preservarse, deben ser reinterpretados conforme a un nuevo esquema que permita suplir las dehiscencias identificadas. Esta reinterpretación,

sistema de la sana crítica si en ese caso ha quedado acreditada la causalidad adecuada entre el hecho del demandado y el daño de la víctima..."(2009, p. 437). 
por lo demás, ha sido realizada ya en otros países del mundo, de donde se infiere entonces que la experiencia comparada puede ser una fiable guía en la materia.

3) Como propuesta, se evidenció entonces que, en primera medida, parece aconsejable incorporar la distinción entre causalidad de hecho y causalidad de derecho. Esta dicotomía permite adoptar un examen natural de la relación causa-efecto que, con teorías como la del juicio sine qua non, efectivamente permite determinar qué suceso es el detonante de otro; del mismo modo, es una tesitura a partir de la cual se pueden restringir los excesos connaturales a la verificación meramente fáctica de la causalidad, a través de criterios de delimitación jurídica (o de selección de causas). Dentro de estos criterios, que integrarían la denominada imputación objetiva, se puede encontrar el de adecuación, el de posición de garante, el de previsibilidad, entre otros más.

4) Se demostró que esta distinción permite entonces resolver varios de los problemas a los que conduce la aplicación de la teoría de la causalidad adecuada como única teoría para resolver el dilema causal. Ahora bien, con ello no se desconoció que este tipo de tesis pueden conducir a nuevos problemas, como el de la sobredeterminación causal o la incertidumbre causal. Con todo, se plantearon algunas nuevas iniciativas para este punto, con las cuales se pretende subsanar los inconvenientes encontrados.

El objetivo, en últimas, es invitar a que se supere la parsimonia tradicional con la que se ha abordado la cuestión y se ponga sobre la mesa la necesidad de repensar, nuevamente, la teoría que se emplea en materia de causalidad. El permanecer impasibles frente a este aspecto no solamente acarrea un altísimo costo doctrinal, sino que también apareja una pérdida irrecuperable en términos de justicia, comoquiera que cada vez son más los casos en los que se depreca la posibilidad de indemnizar por la aplicación descontextualizada de la teoría de la causa adecuada.

Así las cosas, debe seguirse adelante con el debate y, lo que es más importante, adoptar posiciones crítico-reflexivas sobre el particular, ya sea para defender el estado actual o para proponer un nuevo panorama, pero, en cualquier caso, con una adecuada argumentación, que permita el debate nacional e internacional. No se puede olvidar que, como lo decía Adriano de Cupis, 
“cuanto más sobria es la intervención del legislador en la normación de la relación causal respecto a la responsabilidad civil, tanto más ardua es la función del interprete en la solución de las difíciles cuestiones que se presentan en esta materia" (1970, p. 249).

\section{Bibliografía}

Abbagnano, N. (1987). Diccionario de filosofía. Ciudad de México: Fondo de Cultura Económica.

Alexander, L. A. (1987). Causation and corrective justice: does tort law make sense? Law and Philosophy, 1.

Alterini, A. (1992). Responsabilidad civil. Madrid: Abeledo Perrot.

Baraona González, J. (2004). La cuestión causal en la responsabilidad civil extracontractual: panorama de derecho comparado. Revista Chilena de Derecho, 31.

Barnes, D. (2001). Too many probabilities: statistical evidence of tort causation. Law and Contemporary Problems, 64.

Bix, B. (2009). Diccionario de teoría jurídica. Ed. Instituto de Investigaciones Jurídicas - UNAM.

Cafferatta, N. La responsabilidad por daño ambiental.

Cárdenas Mejía,J.P.(2010). Causa extraña como eximente de responsabilidad.En M. Castro de Cifuentes (Ed.), Derechos de las obligaciones. Bogotá: Temis.

Colombia, Consejo de Estado, Sección Tercera. Sentencia del 19 de agosto de 2011.

Colombia, Consejo de Estado, Sección Tercera. Sentencia del 26 de marzo de 2009.

Colombia, Consejo de Estado, Sección Tercera. Sentencia del 5 de julio de 2012.

Colombia, Consejo de Estado, Sección Tercera. Sentencia del 9 de junio de 2010.

Colombia, Corte Suprema de Justicia, de Colombia. Sala de Casación Civil. Sentencia del 26 de septiembre de 2002.

Colombia, Corte Suprema de Justicia, Sala de Casación Civil. Sentencia del 30 de abril de 1976.

Colombia, Corte Suprema de Justicia, Sala de Casación Civil. Sentencia del 16 de mayo de 2011.

De Ángel Yágüez, R. (2000). Algunas previsiones sobre el futuro de la responsabilidad civil. 
De Carvalho Leal, V. (enero-junio, 2010). El daño ambiental y los problemas de determinación de causalidad y carga de la prueba en el régimen jurídico tradicional de reparación en España. Dourados, 2(3).

De Cupis, A. (1970). El daño. Barcelona: Bosch.

Díez-Picazo, L. (1989). Derecho de daños. Madrid: Civitas.

Díez-Picazo, L. (2007). Fundamentos de derecho patrimonial. Tomo V. Madrid: Civitas.

Engle, E. (2009). Aristotelian theory and causation: the globalization of tort. Gujarat National Law University Law Review, 3.

Gil Botero, E. (2013). La teoría de la imputación objetiva en la responsabilidad extracontractual del Estado en Colombia. En C. Bernal Pulido \& J. Fabra Zamora (Eds.), La flosofía de la responsabilidad civil. Estudios sobre los fundamentos filosófico-jurídicos de la responsabilidad civil extracontractual. Bogotá: Universidad Externado de Colombia.

Goldenberg, I. (1984). La relación de causalidad en la responsabilidad civil. Buenos Aires: Ed. Astrea.

Hinestrosa, F. (1961). Curso de obligaciones. Bogotá: Universidad Externado de Colombia.

Jourdain, P.(2014). La causalité. Recuperado de grerca.univ-rennes1.fr/.../288515 pjourdain2.pdf

Larry, A. (1987). Causation and corrective justice: does tort law make sense? Law and Philosophy, 1.

Le Tourneau, P. (2010). La responsabilidad civil. Reimpresión. Bogotá: Legis.

López Mesa, M.J.(2009). Elementos de la responsabilidad civil. Bogotá: Editorial Universidad Javeriana.

Martín Casals, M. (2011a). La 'modernización' del derecho de la responsabilidad extracontractual. Ponencia presentada a la Asociación Española de Profesores de Derecho Civil.

Martín Casals, M. (2011b). La relación de causalidad. En Asociación Española de Profesores de Derecho Civil (Ed.), La modernización del derecho de la responsabilidad extracontractual. Barcelona: Asociación Española de Profesores de Derecho Civil.

Medina Alcoz, M. (2003). La culpa de la víctima en la producción del daño extracontractual. Madrid: Dykinson.

Múrtula, V. (2005). La responsabilidad civil por los daños causados por un miembro indeterminado de un grupo. Madrid: Dykinson. 
Navarro, I. (2013). Derecho de daños. Pamplona: Thomson Reuters.

Ordoqui Castilla, G. (2011). Principios para un derecho americano de los contratosy principios de derecho europeo de la responsabilidad civil. Bogotá: Ed. Ibáñez.

Ortiz Gómez, G. (2010). El nexo causal en la responsabilidad civil.En M. Castro de Cifuentes (Ed.), Derechos de las obligaciones. Bogotá: Temis.

Palsgraf v. Long Island Railroad Co., 248 N.Y. 339, 162 N.E. 99 (N.Y.1928).

Parra Quijano,J. (2009). Manual de derecho probatorio. Bogotá: Librería Ediciones del Profesional.

Pérez Vives, A. (1992). Teoría general de las obligaciones. Bogotá: Ediciones Doctrina y Ley Ltda.

Pizarro, D. (2000). Causalidad adecuada y factores extraños. En F. Trigo Represas (Ed.), Derecho de daños. Buenos Aires: La Rocca.

Pizarro, D. (2006). Responsabilidad civil por riesgo creado y de empresa. Contractual y extracontractual. Tomo I. Buenos Aires: La Ley.

Polinsky,M., \& Shavell, S. (2007). Handbook oflaw and economics. North-Holland: Elsevier.

Prevot, J. (2010). El problema de la relación de causalidad en el derecho de la responsabilidad civil. Revista Chilena de Derecho Privado, (15).

Quézel-Ambrunaz, C. (mars, 2010). La causalité dans le droit de la responsabilité civile européenne. La causalité dans le droit de la responsabilité européenne. Séminaire du GERc, Géneve.

Salvador Coderch, P., \& Fernández Crende, A. (2006). Causalidad y responsabilidad. Indret - Revista para el Análisis del Derecho, 3.

Santos Ballesteros, J. (2013). Responsabilidad civil. Tomo I. Bogotá: Temis.

Scartazzini, G. (1991). Les rapports de causalité dans le droit suisse de la sécurité sociale. Basilea.

Sentis Melendo, S. (1979). La prueba. Los grandes temas del derecho probatorio. Buenos Aires: Ediciones Jurídicas Europa-América.

Solarte Rodríguez, A. (2004). Los actos ilícitos en el derecho romano. Revista Vniversitas, (107).

Spier,J.(2012). Principios de Derecho Europeo de la Responsabilidad Civil. Comentarios a la relación de causalidad. Barcelona: Thomson.

Suescún Melo,J. (2003). Derecho privado. Estudios de derecho civil y comercial contemporáneo. Tomo I. Bogotá: Legis.

Tamayo Jaramillo, J. (2007). Tratado de responsabilidad civil. Tomo I. Bogotá: Temis. 
Trigo Represas, F., \& López Mesa, M. (2011). Tratado de responsabilidad civil. Madrid: La Ley.

Valencia Zea, A. (1950). Derecho civil. Tomo III. Temis. Bogotá.

Velásquez Posada, O. (2009). Responsabilidad civil extracontractual. Bogotá:Temis. Villanueva, G. (2011). El funcionalismo y la imputación objetiva. Bogotá: Ediciones Nueva Jurídica.

Yzquierdo, M. (2001). Sistema de responsabilidad civil, contractual y extracontractual. Madrid: Dykinson. 



\title{
3. El daño desde la teoría de la responsabilidad ambiental
}

\author{
Gustavo Adolfo Ortega Guerrero* \\ Tito Simón Ávila Suárez**
}

\section{Introducción}

El concepto de 'daño ambiental' ha venido experimentando una transformación tanto normativa como jurisprudencial y dogmática, que, aunque continúa involucrando aspectos importantes, puede ser considerada como la superación de la visión primigenia del derecho civil privatista hacia la consolidación del debate que empieza a incluir una visión integral que da cuenta de una serie de valores y principios indispensables para tratar los efectos tanto ecológicos como sociales que están llamados a ser valorados como consecuencia de la generación del daño. Esta perspectiva, precisamente, ha permitido replantear la noción que debe ser adoptada desde la teoría de la justicia y la responsabilidad ambiental a fin de solucionar aquellos problemas vinculados a la contaminación, el daño ambiental y los pasivos ambientales, bajo el entendido de que quien origina el daño ambiental mantiene una responsabilidad que no solo

* Abogado de la Universidad Nacional de Colombia; magíster en Ambiente y Desarrollo de la Universidad Nacional de Colombia y el Instituto de Estudios Ambientales (IDEA); estudiante del Doctorado en Derecho de la Universidad Nacional de Colombia. Profesor ocasional de la Universidad Nacional de Colombia; coordinador del Grupo de Investigación en Derechos Colectivos y Ambientales (Gidca) de la Universidad Nacional de Colombia y docente investigador de la Universidad Manuela Beltrán. Correos electrónicos: gaog30@hotmail.com, gaortegag@unal.edu.co

** Abogado de la Universidad Libre de Colombia; especialista en Derecho Administrativo; especialista en Gerencia de Recursos Naturales; especialista en Derecho Ambiental; magíster en Biociencias y Derecho de la Universidad Nacional de Colombia. Profesor de las especializaciones en Derecho Ambiental de la Universidad del Rosario y Gestión Ambiental de la Escuela de Posgrados de la Policía Nacional (Espol) y la Universidad de La Sabana, y de la Maestría en Gestión de la Empresa Minero-Energética de la Escuela de Administración de Negocios (EAN).Correo electrónico: titosimonavilasuarez@gmail.com 
recae en la identificación de una conducta, sino adicionalmente en la exigencia de una responsabilidad ampliada que le exige restaurar in natura y compensar por los daños ambientales, tanto ecológicos como sociales, cuando se observa que estos han sido trasgredidos. Los diferentes avances jurisprudenciales y dogmáticos, incluyendo la diferenciación del daño ambiental puro e impuro, son solo una muestra de la necesidad dinámica de establecer elementos tanto sustanciales como instrumentales que permitan encausar la teoría sobre el daño ambiental dentro de los criterios de la justicia ambiental, especialmente vinculados a las actividades de uso, aprovechamiento, explotación, extracción, consumo e intercambio de los recursos naturales.

Por lo tanto, el presente trabajo busca identificar y abordar esta transformación respecto al daño ambiental en sus tres principales dimensiones: i) en una revisión del derecho en las disposiciones del derecho ambiental internacional, en las disposiciones constitucionales en Colombia y en los aspectos normativos de la legislación que desarrollan los instrumentos de regulación directa, como el procedimiento sancionatorio ambiental; ii) en la conceptualización jurisprudencial del daño ambiental tanto de la jurisprudencia internacional comparada como de los avances de la jurisprudencia nacional; $y$, finalmente, iii) frente a las cuestiones dogmáticas del daño ambiental y otros conceptos importantes, como la contaminación y los impactos y daños ambientales, por ejemplo, los pasivos ambientales. ${ }^{1}$

\subsection{Avances desde la jurisprudencia internacional y nacional sobre el daño ambiental y la teoría de la responsabilidad ambiental} Para empezar, debe considerarse que el tema del daño ambiental ha transcendido con los avances del derecho ambiental a partir de las conceptualizaciones que marcan la evolución de las medidas sobre la protección del ambiente, y que inician con el derecho ambiental internacional (DAI) desarrollado a partir de las grandes declaraciones ambientales, esto es, la Declaración de Estocolmo sobre Ambiente Humano de 1972, la Declaración de Río de Janeiro de 1992 y la Declaración de Johannesburgo sobre Desarrollo Sostenible de 2002. Aunque, si bien se aclaran las disposiciones del derecho suave (soft law) o no vinculante, como la primera y la última declaración, y las disposiciones de 'derecho fuerte'

\footnotetext{
${ }^{1}$ El presente trabajo se vincula al desarrollo de Ávila (2014),y fue elaborado por los autores a partir de la investigación sobre daño ambiental ante la Autoridad Nacional de Licencias Ambientales (ANLA).
} 
vinculante (hard law), que, para el caso del ordenamiento jurídico colombiano, se remiten a la Declaración de Río de Janeiro de 1992, las cuales fueron incorporadas por el artículo 10 de la Ley 99 de 1993 como parte de los elementos que deben aplicarse a la política ambiental nacional (onU, 1972, 1992, 2002; CRC, 1993).

En esta medida, se identifican dentro del sistema de principios desarrollados internacionalmente las disposiciones referidas al tema del daño ambiental. Por ejemplo, la Declaración de Estocolmo en su principio 22 establece que "los Estados deben cooperar para continuar desarrollando el derecho internacional en lo que se refiere a la responsabilidad y a la indemnización a las víctimas de la contaminación y otros daños ambientales que las actividades realizadas dentro de la jurisdicción o bajo el control de tales Estados causen en zonas situadas fuera de su jurisdicción”, y en el principio 23 indica que "toda persona, de conformidad con la legislación nacional, tendrá la oportunidad de participar, individual o colectivamente, en el proceso de preparación de las decisiones que conciernen directamente a su medio ambiente y, cuando éste haya sido objeto de daño o deterioro, podrá ejercer los recursos necesarios para obtener una indemnización" (onU, 1972).

Posteriormente, en la Declaración de Río de Janeiro de 1992, se instituyó dentro de su principio 2 el 'principio de soberanía' de los Estados sobre sus recursos, sobre su política ambiental y sobre sus actividades, siempre que no afecten a otros Estados, idea que se desarrolló teóricamente bajo la denominación de la 'regla del no daño' o responsabilidad por daños ocasionados a otros países (onu, 1992; Toly Verheyen, 2004). También, en el principio 10, se reconoció la necesidad de establecer garantías por parte de los Estados, quienes a partir de ese momento debían conceder "acceso efectivo a los procedimientos judiciales y administrativos, entre éstos el resarcimiento de daños y los recursos pertinentes". En el principio 13, se menciona el deber de los Estados para "[...] desarrollar la legislación nacional relativa a la responsabilidad y la indemnización respecto de las víctimas de la contaminación y otros daños ambientales", así como para impulsar la creación de nuevas leyes internacionales en materia de responsabilidad e indemnización "[...] por los efectos adversos de los daños ambientales causados por las actividades realizadas dentro de su jurisdicción [...]”.

Más tarde, con la aprobación de la Constitución Política de 1991, se determinó como parte de las obligaciones a cargo del Estado, dentro del 
artículo 80, la planificación sobre el “[...] manejo y aprovechamiento de los recursos naturales, para garantizar su desarrollo sostenible, su conservación, restauración o sustitución, pero adicionalmente, el deber de '[...] prevenir y controlar los factores de deterioro ambiental, imponer las sanciones legales y exigir la reparación de los daños causados". Igualmente, el artículo 88 señala que la ley “[...] definirá los casos de responsabilidad civil objetiva por el daño inferido a los derechos e intereses colectivos [...]" (ANC, 1991).

Y de forma más reciente, dentro de los desarrollos de la legislación en Colombia en materia de responsabilidad frente al daño ambiental, en la Ley 1333 de 2009, que desarrolló las disposiciones sobre el procedimiento sancionatorio ambiental, se incluyó dentro de las infracciones objeto de investigación y sanción "la comisión de un daño al medio ambiente, con las mismas condiciones que para configurar la responsabilidad civil extracontractual" (el daño, el hecho generador con culpa o dolo y el nexo causal). Al respecto, en el procedimiento sancionatorio ambiental se diferencia entre la 'sanción' propiamente dicha y la 'responsabilidad' "que para terceros pueda generar el hecho en materia civil” (artículo 5\%), aclarándose además frente a las medidas compensatorias que "la imposición de una sanción no exime al infractor del cumplimiento de las medidas que la autoridad ambiental competente estime pertinentes establecer para compensar y restaurar el daño o el impacto causado con la infracción" (artículo 31). Un aspecto adicional que puede encontrarse en la Ley 1333 de 2009 ha sido la aplicación del principio de prevención que se desarrolla a través de la posibilidad de decretar medidas preventivas (artículo 36) a fin de evitar la generación del daño o peligro sobre el ambiente (previniendo además la agravación o generación de daños adicionales) (CRC, 2009).

\subsubsection{Jurisprudencia internacional comparada en materia del daño ambiental y responsabilidad ambiental}

La conceptualización y fundamentación jurídica del daño ambiental, como la teoría de la responsabilidad ambiental, se han visto marcadas en la actualidad por los avances y la evolución de desarrollos del derecho ambiental, que antes estaban reducidos de manera exclusiva a las teorías puras de la responsabilidad civil y/o administrativa. Es así que se han generado nuevas tendencias para producir un cambio de perspectivas encaminadas a garantizar el conjunto de valores sociales reconocidos en los mandatos constitucionales y en los ordenamientos jurídicos contemporáneos en materia de protección ambiental. 
De arreglo con este argumento, han existido notables progresos de la conceptualización jurisprudencial del daño ambiental, superando a su vez las primeras fases de la responsabilidad civil extracontractual, que, si bien aporta elementos muy importantes, pueden resultar insuficientes para abordar el tema desde una perspectiva de valoración y reparación integral del daño. En esta medida, se establece un análisis jurisprudencial en contexto, con alcances cada vez más inclusivos y garantistas, partiendo de planteamientos sobre las problemáticas ambientales desde la perspectiva ecológica asociada a los bienes afectados, pero que cada vez más van integrando aspectos sociales y elementos de protección y reparación más allá de las sanciones e indemnizaciones monetarias, lo que, en otras palabras, implica una visión integral a los problemas de valoración ambiental del daño.

Comenzando con la jurisprudencia de la Corte Internacional de Justicia (CIJ), si bien no se ha manifestado de fondo sobre aspectos del DAI, sí se han suscitado algunos casos relativos al daño ambiental transfronterizo (Uribe Vargas y Cárdenas Castañeda, 2010). Así, por ejemplo, la Asamblea General de la onu requirió Opinión Consultiva de la cij en 1996 respecto a la legalidad del Tratado de Utilización de las Armas Nucleares (The legality of the Threat or Use of Nuclear Weapons), en la cual se sostuvo la necesidad de reconocer que el ambiente está constante amenazado e, igualmente, que este "no es una abstracción", sino el espacio "donde viven los seres humanos y del cual depende la calidad de vida y salud, así como el bienestar de las generaciones del futuro. En consecuencia deja claro en cuanto la responsabilidad de los Estados de actuar dentro de los límites sin dañar el ambiente o los territorios" (ciJ, 1996).

En otro caso, como el de Gabcikovo-Nagymaros (1997), concerniente a la construcción y funcionamiento del sistema de exclusas Gabcikovo-Nagymaros entre la República Popular de Hungría y la entonces República Socialista de Checoslovaquia, quienes pretendían utilizar los recursos naturales de la sección Bratislava-Budapest del río Danubio respecto a proyectos hidráulicos y energía, la Corte señaló que en los últimos tiempos la protección del 'equilibrio ecológico' debe ser considerada como un interés esencial de los Estados, en donde se impone la prevención en virtud del carácter "irreversible de los daños causados al ambiente y de los límites inherentes a los mecanismos de reparación de este tipo de perjuicios" (cIJ, 1997).

Dando paso a los desarrollos más importantes a nivel de jurisprudencia internacional, se cita el caso Zander vs. Suecia, resuelto por la Corte Europea 
de Derechos Humanos (CEDH) en 1993, que vinculará la conceptualización del 'daño ambiental' con la teoría de la responsabilidad ambiental y las 'medidas de compensación'. Con base en la demanda, la Corte analiza la contaminación por vertimientos domésticos e industriales que fueron permitidos por los gobiernos nacional y regional de Suecia mediante la expedición de licencia administrativa, en la cual se comprobaría, a través de su seguimiento, la existencia de altos contenidos de cianuro en las fuentes de agua que abastecían a una comunidad local. La argumentación de la CEDH se remite de manera directa al desconocimiento de 'derechos civiles' de los demandantes, por la no aplicación de medidas de prevención suficientes frente a daños causados por actividades peligrosas para el ambiente, en especial aquellas que por virtud de los usos del suelo conllevaron inter alia (entre otras cosas) a la contaminación del agua. Y concluye la Corte que, debido al desconocimiento de la legislación interna de Suecia, específicamente de la Ley 1969 sobre las medidas cautelares frente a la contaminación, y de la Ley de Daño Ambiental de 1986 en relación con la indemnización del daño causado, al no haber sido objeto de control judicial ni los hechos de la empresa ni los actos administrativos expedidos por la Junta de Licencias, se declara la violación del artículo $6^{\circ}$ del Convenio Europeo de Derechos Humanos en materia de garantías judiciales, y se reconoce a favor de las víctimas una indemnización por los 'daños morales' ocasionados, ya que, a pesar de las medidas preventivas, como el abastecimiento de agua no contaminada para los afectados, estos vivían en una constante preocupación frente a la posibilidad de un eventual envenenamiento (CEDH, 1993).

Acorde con lo anterior, puede verse cómo en la evolución de la responsabilidad frente al daño ambiental la jurisprudencia internacional ha incluido una serie de elementos sociales que sobrepasan la apreciación del simple daño ecológico, pues, como se deriva de la ratio decidendi (o razón fundamental de la decisión) del caso Zander vs. Suecia, las medidas de compensación se centran además en los valores y principios sociales que pudieron verse fragmentados, por ejemplo, la 'confianza legítima' de la sociedad y las comunidades frente a las medidas del Estado.

En idéntico sentido, otras sentencias de la CEDH sobre la protección de derechos desconocidos, que han incluido en sus decisiones medidas no circunscritas exclusivamente al reconocimiento del pago monetario frente al daño ambiental ocasionado. Así, por ejemplo, en el caso Fadeyeva vs. Rusia (2005), la Corte analiza el caso de contaminación por las emisiones procedentes de 
una fábrica de acero que afectaba el lugar de residencia de los demandantes. $\mathrm{Al}$ respecto, se menciona la situación en la que, a pesar de haberse establecido un perímetro de control ambiental en la zona de influencia por parte de las autoridades, los demandantes, al igual que miles de personas, fueron alojados en apartamentos dentro de dicho perímetro. En consecuencia, la CEDH advierte que, pese a las decisiones judiciales internas que obligaban al gobierno a reubicar a las poblaciones afectadas, esto nunca se llevó a cabo, y, por lo tanto, se desconocieron los derechos a la vida privada y a la familia, lo que involucró serios problemas, como la afección psicológica y cierto grado de sufrimiento físico ante la exposición a la contaminación, hecho que, además de requerir indemnización en términos monetarios, obliga al gobierno a cumplir medidas futuras para "el reasentamiento de la demandante en una zona ecológicamente equilibrada" y otro tipo de soluciones adicionales que deben ser adoptadas para resolver la situación particular de la demandante en cuanto a la reparación del daño (CEDH, 2005a).

Otro caso que refleja el tema del daño ambiental es Giacomelli vs. Italia (2006), en el cual la CEDH reconoce la violación al artículo $8^{\circ}$ del Convenio Europeo de Derechos Humanos por afectación a la vida privada por contaminación de una planta de tratamiento de residuos, que incluye contaminación por 'residuos peligrosos'y remediación a través de productos químicos, los cuales generaron afectaciones durante años al demandante (CEDH, 2006).

También, se encuentran pronunciamientos de la CEDH en otras instancias sobre las garantías de derechos constitucionales y derechos fundamentales, que tienden a ser desconocidas por los sistemas jurídicos de los países o que dejan de ser aplicadas por los gobiernos nacionales a pesar de la existencia de decisiones judiciales nacionales, por ejemplo, en la garantía del reconocimiento a los derechos a la vida, a un ambiente sano, a la evaluación de impactos adversos sobre el ambiente, y que ocasionan daños a los ecosistemas locales y la salud humana, como en las sentencias de los casos López Ostra vs. España (1994), Taskin y otros vs. Turquía (2004) y Okyay y otros vs. Turquía (2005) (CEDH, 1994, 2004, 2005b). ${ }^{2}$

\footnotetext{
${ }^{2}$ La jurisprudencia citada corresponde a casos de contaminación proveniente de actividades industriales por empresas de cuero, contaminación por cianuro de proyectos mineros de explotación de oro y operación de centrales termoeléctricas en materia de contaminación del aire y cenizas.
} 
De otro lado, bajo la perspectiva del derecho comercial internacional, se cita la sentencia del Tribunal Internacional de Arbitramento ad hoc en relación al laudo Trail Smelter Case (contaminación de hornos de fundición), que resolvió el litigio Estado Unidos vs. Canadá en materia de daños por contaminación transfronteriza, reconociendo el problema ambiental generado por las plantas fundidoras de azufre ubicadas en Canadá sobre los campos y las poblaciones del Estado de Washington en los Estados Unidos. En dicho asunto, el Tribunal concluyó que, "según los principios del derecho internacional, así como de la ley de Estados Unidos, ningún Estado tiene derecho de usar o permitir que se use el territorio de modo que se causen daños por razón de emanaciones en el territorio o hacia el territorio de otro Estado o a la propiedad o personas que allí se encuentren, cuando se trata de un hecho con consecuencias graves y el daño sea determinado a través de pruebas claras y concluyentes" (TSAT, 1941).

Sobre la sentencia al laudo Estados Unidos vs. Canadá, es importante señalar ciertas conclusiones que han sido advertidas por diferentes teóricos, entre ellas: 1) que aplica implícitamente una teoría de 'responsabilidad objetiva’ por cuanto no se aportó ninguna prueba sobre la negligencia por parte de Canadá, y el Tribunal simplemente partió de su reconocimiento; y 2) que se aplicaron las medidas de responsabilidad objetiva bajo la conceptualización del sistema anglosajón del common law, en el cual se diferencia la 'responsabilidad' (responsibility) u obligación frente a los actos propios y la responsabilidad de indemnización o compensación (liability) por incumplimiento de los deberes jurídicos, en especial los de prevención (Gómez Robledo, 1992). ${ }^{3}$

Uno de los casos más recientes, paradigmáticos y representativos de la jurisprudencia comparada es el caso Salazar y otros vs. Chevron-Texaco, por la contaminación por derrame de petróleo de la empresa transnacional sobre la Amazonía en Ecuador, en la cual se destacan los argumentos acogidos por la Corte Provincial de Sucumbíos en la condena proferida contra la ChevronTexaco, que, no obstante de retomar la aplicación bajo una perspectiva civilista y privatista al examinar los elementos de la responsabilidad subjetiva que

\footnotetext{
${ }^{3}$ No obstante, como sostiene Gómez Robledo (1992), aunque puede ser uno de los primeros casos en el derecho internacional en haber definido una responsabilidad objetiva en materia del daño ambiental, algunos sostienen que había un reconocimiento tácito de responsabilidad en el mismo acuerdo arbitral por parte de Canadá.
} 
señala el artículo 1480 del Código Civil ecuatoriano (hecho, daño y nexo de causalidad), aplicó la 'responsabilidad objetiva' por la inobservancia de los "reglamentos de la industria y de otras normas administrativas"(CPs, 2012).

La Corte Nacional de Ecuador confirmó los argumentos de la Corte Provincial de Sucumbíos, reconociendo además que "existe la debida motivación respecto a la responsabilidad objetiva [...]", pues existe la obligación de "quien causó el daño" “[...] de reparar, es decir se determina la responsabilidad y el nexo causal entre las actividades realizadas por la accionada y el daño ambiental, lo que ha conllevado a que se infrinja la ley ecuatoriana”. Luego de hacer un ejercicio de derecho comparado en materia de responsabilidad sobre el daño ambiental, concluye, con base en la Constitución Política de Ecuador, que la responsabilidad ambiental es objetiva, ya que "en materia ambiental la responsabilidad subjetiva no funciona [...] y muchos sistemas jurídicos acuden a la teoría de la responsabilidad objetiva”. Y, desde el análisis constitucional, se menciona la necesidad de que "todo daño al ambiente, además de las sanciones correspondientes, implicará también la obligación de restaurar integralmente los ecosistemas e indemnizar a las personas y comunidades afectadas" (CNE, 2013).

\subsubsection{Jurisprudencia nacional en materia de daño ambiental}

La jurisprudencia colombiana en materia de responsabilidad por daño ambiental pasa por el desarrollo realizado por la Corte Suprema de Justicia (csJ, 1976) en el caso de responsabilidad civil por contaminación al ambiente por los daños causados por la emanación de gases sulfurosos arrojados a la atmósfera (corrosión y deterioro), los cuales se depositaron en las instalaciones, maquinarias, muebles, enseres, equipos y herramientas de propiedad de Hilanderías Medellín S.A. Sin embargo, esta jurisprudencia está considerada como la definición bajo la óptica de protección a la propiedad privada, que implica reivindicación por medio de la indemnización o compensación por los daños inferidos a ella.

Así, la csj acudió a figuras del derecho civil como la responsabilidad por el abuso del derecho y la teoría del riesgo por actividades peligrosas. La Corte se refirió al tema del daño ambiental mediante la 'teoría del abuso del derecho', construida desde lo civil como: i) los derechos subjetivos que pueden y deben ejercerse sin causar daño a los demás; y ii) la excepción de los derechos que no pueden ser ejercidos sin lesionar un derecho ajeno, condensado 
en el hecho de que "nadie puede hacer uso" de sus derechos "en prejuicio de terceros", puesto que "la ley no los ha reconocido o conferido como facultad que permita atender contra el derecho ajeno, sino como medio legítimo de satisfacción de necesidades individuales o colectivas sin prejuicio de los demás". Es decir que "el que daña a otro so pretexto de usar derecho cuyo ejercicio no implique ineludiblemente daño ajeno no está ejerciéndolo sino abusando de él". Abiertamente es la teoría sobre el 'uso de los derechos', que tienen como límite de su ejercicio el lugar donde comienzan los ajenos, lo cual, en desconocimiento de este principio, puede dar lugar a la declaratoria de responsabilidad con su respectiva indemnización. En la sentencia, se afirma que quien comete un hecho ilícito de manera culposa o dolosa que no se ha desvirtuado con la fuerza mayor o caso fortuito es "civilmente responsable por abuso del derecho" (ibíd.).

Importante señalar que la CSJ remite a las sentencias del 30 de noviembre de 1935, 14 de marzo y 31 de mayo de 1938, citadas en el caso Hilanderías Medellín S.A. (1976), pero también más adelante a las sentencias de los casos Acosta vs. Gases del Caribe S.A. (1999) y Ampeatum vs. Mesta Shipping Company y otros (2011), para argumentar, con respecto a lo establecido en el artículo 2356 del Código Civil, que la responsabilidad civil generada por la contaminación ambiental corresponde al régimen de las actividades peligrosas en 'virtud del riesgo o el peligro consustancial', las cuales se definen "socialmente útiles y aún necesarias pero también peligrosas", y que, pese a ser lícitas, no autorizan dañar a los demás, bastando solo con la demostración del daño y el nexo de causalidad para obtener la reparación "del perjuicio sufrido, salvo prueba de fuerza mayor, o caso fortuito o de la culpa exclusiva de la propia víctima" (csj, 1976, 1999).

En este primer momento, la Corte establece una concepción de derechos individuales y la propiedad privada, que no describe al ambiente como un bien común y un derecho colectivo, con lo cual se concluye que, si bien representa un avance en materia de indemnización o compensación civil por el daño a la propiedad, ya sea por la 'teoría del riesgo creado o abuso del derecho', no se estima una noción de ambiente que merezca protección de forma directa, dejándolo a la suerte de la protección de la propiedad y los límites que se 
establezcan para el uso de los derechos sin dañar los de los terceros. ${ }^{4}$ Por lo tanto, pese a constituirse en uno de los primeros precedentes jurisprudenciales, en esta sentencia no se desarrolla la teoría de responsabilidad por daño o contaminación ambiental, y tampoco se tienen en cuenta los desarrollos de la Ley 23 de 1973 (crc, 1973) y el Decreto-Ley 2811 de 1974, ${ }^{5}$ como se ha reconocido desde el punto de vista dogmático (CRC, 1974). ${ }^{6}$

Es en la sentencia del caso Ampeatum vs. Mesta Shipping Company y otros de 2011, anteriormente citada, que la csj reconoce la restricción de los anteriores pronunciamientos jurisprudenciales de la jurisdicción civil y el daño ambiental (también ecológico) como un atentado a aminoración a un bien público y colectivo que transciende los derechos individuales. Por lo tanto, la Corte señala el 'ambiente' como un bien jurídico inmaterial, unitario y autónomo, con un valor colectivo, con una dimensión social, pública, concerniente al Estado, que además constituye un 'bien y principio constitucional'

dentro del Estado social de derecho (artículos $1^{\circ}, 2^{\circ}$ y 366 superiores), un derecho fundamental por conexidad al estar ligado con la vida y la salud (artículos 11 y 49 superiores), un derecho colectivo (ser social) que compromete a la comunidad (artículo 88 superior) y un deber constitucional en cabeza de todos (artículos 8 79,95 y 333 superiores), [...] también tiene el carácter de servicio público [...], forma parte de los derechos colectivos [...], cuya vía judicial de protección son las acciones populares (artículo 88 superior) [...],y cuya

\footnotetext{
${ }^{4}$ La csj refiere al ejercicio de actividades contaminantes en lugares alejados en los que quizá bajo un estudio técnico podría demostrarse que los ecosistemas son más frágiles o que pueden recaer en impactos sobre personas vulnerables.

${ }^{5}$ Por ejemplo, el artículo 32 del Decreto-Ley 2811 de 1974 (PRC). Igualmente, en el plano internacional se contaba como herramienta de análisis lo señalado en la Declaración de la Conferencia de la Naciones Unidas sobre el Ambiente Humano de Estocolmo de 1972, previamente citada.

${ }^{6}$ Siguiendo este análisis, Sarmiento García (2009) reconoce que, en nuestra legislación ambiental, especialmente a partir de lo señalado en el artículo 16 de la Ley 23 de 1973, se establece un régimen de responsabilidad civil bajo un esquema objetivo, que no tiene en cuenta si la conducta se desplegó con o sin culpa, como factor determinante de la responsabilidad por los daños causados al ambiente por el Estado y los particulares, aunque lo limita a los 'recursos naturales' de propiedad privada.
} 
importancia en la Constitución es de tal magnitud que implica para el Estado “unos deberes calificados de protección [...]"(ccc, 2010b). ${ }^{7}$

Y al mismo tiempo reconoce la existencia de afectaciones individuales cuando el daño es determinado o determinable, para lo cual deja de ser daño ambiental y se convierte en detrimento de los derechos individuales.

Aquí existe un cambio sustancial en la jurisprudencia de la csJ, por cuanto se cita el contenido del artículo 16 de la Ley 23 de 1973, en el cual se afirma que "el Estado será civilmente responsable por los daños ocasionados al hombre o a los recursos naturales de propiedad privada como consecuencia de acciones que generen contaminación o detrimento del medio ambiente. Los particulares lo serán por las mismas razones y por el daño o uso inadecuado de los recursos naturales de propiedad del Estado". Por esta razón, reconoce que las acciones idóneas frente a la generación del daño ambiental tienen que corresponder a la acción constitucional de la acción popular, mientras que, en el segundo caso, para obtener el pago y reconocimiento de indemnización de un conjunto plural de individuos, podrá acudirse a las acciones de grupo o a la acción ordinaria de responsabilidad civil (csJ, 2011).

La Corte Constitucional de Colombia (ccc) ha establecido a través de una serie de sentencias algunos criterios de interpretación frente al daño ambiental, en dos temas principales: i) el licenciamiento ambiental y ii) el procedimiento sancionatorio ambiental. En cuanto al licenciamiento ambiental, la ccc, en la Sentencia C-035 de 1999, se ha referido a la relación existente entre la licencia ambiental y la prevención de los daños ambientales, por ejemplo, a la necesidad de concebir la interpretación de las obligaciones surgidas del instrumento ambiental, de acuerdo con la incidencia de cada uno de los proyectos, en la medida en que los impactos pueden varían según la "naturaleza y magnitud de la respectiva obra o actividad" (ccc, 1999). En el mismo sentido, se desarrolla la argumentación en la C-746 de 2012, en la cual se vincula la licencia ambiental como instrumento para evitar y mitigar los daños ambientales (ccc, 2012a).

Así mismo, la ccc ha aclarado en la revisión de tutela de la Sentencia T-693 de 2012 (caso Unión Temporal Desarrollo Vial del Valle del Cauca y

${ }^{7} \mathrm{La}$ csj hace referencia a esta sentencia para argumentar el alcance constitucional del concepto de ambiente, referido por la ccc a las infracciones ambientales del procedimiento sancionatorio ambiental. 
Cauca vs. Ministerio de Ambiente y Desarrollo Sostenible) que, al aprobar una licencia ambiental, la autoridad ambiental competente puede hacerlo de manera general, obteniendo la facultad de condicionarla al cumplimiento de una serie de requisitos y obligaciones, con el fin de prevenir, mitigar, restablecer o compensar los 'daños causados' por la obra o proyecto (ccc, 2012b).

Ahora, en materia del procedimiento sancionatorio ambiental, la ccc en Sentencia C-293 de 2002, acudiendo al principio de precaución, estableció como criterio de interpretación que una autoridad ambiental puede proceder "a la suspensión de la obra o actividad que desarrolla el particular, mediante el acto administrativo motivado, si de tal actividad se deriva daño o peligro para los recursos naturales o la salud humana, así no exista la certeza científica absoluta", pues las consecuencias "del riesgo consiste [sic] en que el deterioro ambiental debe ser neutralizado desde sus propios orígenes y sin retardar la actuación hasta el momento mismo en que los efectos negativos se produzcan o generen mayor daño" (ccc, 1999).

Sobre el procedimiento sancionatorio ambiental, la ccc ha efectuado varios pronunciamientos en relación con la constitucionalidad de la Ley 1333 de 2009. Comenzando con la Sentencia C-401 de 2010, la Corte se refiere a la función sancionatoria y medidas preventivas del artículo $4^{\circ}$ y a la diferencia entre la sanción (artículo 40 ibíd.) y el cumplimiento de las medidas de compensación y restauración de 'daño' o el 'impacto' cuando la autoridad ambiental competente estime necesario (artículo 31 ibíd.) (ccc, 2010a).

En la Sentencia C-703 de 2010, la ccc se refiere a otros elementos de la interpretación de la Ley 1333 de 2009 en materia de procedimiento sancionatorio ambiental y de manera directa a las medidas que deben adoptar las autoridades ambientales al respecto:

La afectación, el daño, el riesgo o el peligro que enfrenta el medio ambiente constituyen el punto de partida de la formulación de los principios que guían el derecho ambiental y que persiguen, como propósito último, dotar a las respectivas autoridades de instrumentos para actuar ante esas situaciones que comprometen gravemente el ambiente y también los derechos con él relacionados. Tratándose de daños o de riesgos se afirma que en algunos casos es posible conocer las consecuencias que tendrá sobre el ambiente el desarrollo de determinado proyecto, obra o actividad, de modo que la autoridad 
competente puede adoptar decisiones antes de que el riesgo o el daño se produzcan, con la finalidad de reducir sus repercusiones o de evitarlas y cuando tal hipótesis se presenta opera el principio de prevención que se materializa en mecanismos jurídicos, tales como la evaluación del impacto ambiental o el trámite y expedición de autorizaciones previas, cuyo presupuesto es la posibilidad de conocer con antelación el daño ambiental y de obrar, de conformidad con ese conocimiento anticipado, a favor del medio ambiente (ccc, 2010c).

Ahora, la ccc en Sentencia C-632 de 2011, aunque no define lo que debe entenderse por daño ambiental, sí establece quiénes son los sujetos pasivos o 'víctimas' de este, observando el valor intrínseco del ambiente como sujeto de derechos que requiere protección autónoma. Igualmente, señala las medidas de compensación, reconociendo que no existe una enumeración taxativa, pero que estas se circunscriben a los límites de la valoración técnica del daño o impacto negativo, incluyendo el proceso de restitución y restauración ecológica, la magnitud del daño sufrido por los ecosistemas y el alcance de la medida definida, todo lo cual debe estar encaminado a establecer una restitutio in natura del daño al activo natural afectado, por medio de medidas necesarias para volver al estado anterior las cosas cuando sea posible (ccc, 2011). Concluye la ccc en la precitada sentencia que las subreglas constitucionales que deben ser tenidas en cuenta al momento de concretar las medidas compensatorias ambientales:

i) están dirigidas, única y exclusivamente, a restaurar in natura el medio ambiente afectado, buscando que éste retorne a la situación en que se encontraba antes del daño ambiental, o a lograr su recuperación sustancial; ii) las mismas se encuentran a cargo de organismos técnicos de naturaleza administrativa, y solo resultan imponibles si se demuestra la existencia de la infracción ambiental y del daño ocasionado al medio ambiente o a los recursos naturales; iii) en razón a su carácter estrictamente técnico, no están definidas previamente en la ley y su determinación depende del tipo de daño que se haya causado al medio ambiente; iv) cualquiera sea la medida compensatoria a adoptar, la misma debe guardar estricta proporcionalidad con el daño ambiental, pudiendo, en todo caso, ser objeto de los respectivos 
controles administrativo y judicial; finalmente, v) tales medidas no tienen naturaleza sancionatoria, pues el fin que persiguen es esencialmente reparatorio.

Para la ccc $(1998,2004,2010 d)$, como se puede observar en las sentencias C-320 de 1998, T-294 de 2004 y T-851 de 2010, el daño ambiental además es visto como un componente que afecta el derecho al ambiente sano, con la correspondiente incidencia en la vida de los seres vivos. En principio, refiere indistintamente a daño ecológico y ambiental, como una obligación del Estado para buscar la prevención del daño a través del manejo de los factores de deterioro y exigiendo a su vez la reparación de los daños causados conforme a lo establecido en el artículo 80 de la Constitución Política, sea o no el resultado de la realización de una actividad lícita (conducta antijurídica).

Ahora, en cuanto a la jurisprudencia desarrollada por el Consejo de Estado de Colombia (CEC), se puede identificar una aproximación conceptual del daño desde el caso Fundación Biodiversidad vs. Dagma (2000), concebido como acción proveniente de los humanos que ataca o impacta los elementos ambientales en el entendido de producir un daño social por afectación de los 'intereses difusos' y que también puede ser el producto de una defectuosa evaluación de la autoridad ambiental al evaluar los proyectos por acción u omisión (criterio reiterado en la sentencia de acción popular, caso Fundepúblico vs. IDU) (2009) (cEc, 2000, 2009).

Sin embargo, el Consejo de Estado, quien a su vez retoma la sentencia de la csj en el caso Ampeatum vs. Mesta Shipping Company y otros (2011), refiere a la definición del 'daño ambiental puro' afectación a los bienes 'naturales' y el 'ambiente' por su contenido colectivo, y 'consecutivo o impuro' cuando se trata de otros elementos afectación en la salud o patrimonio de los humanos desarrollados básicamente por la doctrina, en el cual se resalta la necesidad de 'remediar' o 'rehabilitar' el daño ambiental (causados en este caso a los cuerpos de agua), es decir que se establece una obligación para tratar de volver las cosas a su estado anterior (por ejemplo, en la sentencia de acción de grupo del Consejo de Estado, caso Hernández Santacruz y otros vs. Ministerio de Ambiente y Ecopetrol) (cEc, 2004). En fin, el daño ambiental puro son todos los perjuicios que se causan directamente al ambiente, con independencia de los derechos subjetivos de las personas que se vean afectadas (CEc,2013). Mientras el 'daño ambiental impuro'se presenta cuando, pese a existir una afectación de 
carácter colectivo, se generan de igual manera perjuicios de índole particular, "daños individuales que son la consecuencia o el reflejo de la lesión ambiental [...] cuyo derecho no es de corte subjetivo-colectivo, sino subjetivo-individual" (Geneviève y Patrice, 1998; cEc, 2014b). ${ }^{8}$

Una concepción más amplia del daño ambiental, puede verse, por ejemplo, en la sentencia de acción popular del Consejo de Estado, caso Colina vs. Ministerio de Ambiente y otros (cEc,2007b), desde la órbita de la prevención, en la cual el daño se tiene como aquel que impide percibir los beneficios que ofrecen los bienes naturales y ambientales; en consecuencia, la reparación da derecho a reclamar la respectiva indemnización, la cual incluye, de una parte, "los costos contraídos o que se vayan a contraer por concepto de las medidas razonables de restauración del medio ambiente contaminado"y, de otra parte, los gastos incurridos en la toma de medidas preventivas, siempre y cuando haya una amenaza grave e inminente de daños por contaminación. ${ }^{9}$

Otro aspecto importante de la jurisprudencia administrativa se encuentra en el caso de la sentencia del cec del $1^{\circ}$ de marzo de 2011, en la cual se prescribe la solución de los costos contraídos para atender las medidas restaurativas del 'medio ambiente contaminado' y los gastos por las medidas preventivas, que serían las medidas inmediatas para contrarrestar los efectos del daño ambiental, para lo cual una de las finalidades de la función administrativa radica en perseguir la compensación del daño ambiental y social, con arreglo a la ley (CEc, 2011).

Por otra parte, en relación con la teoría general del daño, el cec ha desarrollado en la sentencia del caso Buitrago Quinteros y otros vs. Distrito Capital de Bogotá (2012) cierta argumentación para interpretar el artículo 90 constitucional, en el cual se determina que "el Estado responderá patrimonialmente por los daños antijurídicos que le sean imputables, causados por la acción o la omisión de las autoridades públicas”. Desde esta perspectiva, se incluye no solamente el daño patrimonial, sino también el daño moral, y el daño fisiológico asociado por afectación a la vida de relación, que comprende

${ }^{8} \mathrm{El} \mathrm{cec}$ remite, e. g., al trabajo de Geneviève y Patrice (1998) respecto a la diferenciación conceptual de daño ambiental puro y daño ambiental impuro.

${ }^{9}$ Esta perspectiva del daño puede circunscribirse en una visión más utilitarista, es decir, la importancia sobre los beneficios percibidos de los servicios que ofrecen los ecosistemas, mas no por el valor intrínseco que también poseen estos. 
la afectación a salud e integridad de las personas por alteraciones a las condiciones de existencia.

\subsection{Aproximación teórica del daño ambiental}

A continuación, se presenta una perspectiva del daño desde el punto de vista teórico, que indica la superación de las posiciones que se plantean desde la responsabilidad civil y, más bien, bajo perspectivas integrales o garantistas desde la responsabilidad ambiental. Aquí es necesario comenzar con una serie de cuestiones previas a la conceptualización jurídica del daño ambiental: en primer lugar, que el daño está íntimamente ligado con las acciones o conductas desplegadas por agentes, sujetos o individuos, identificadas en la contaminación y los impactos ambientales sobre los cuales debe analizarse su grado de interacción; en segundo lugar, que la ausencia de medidas preventivas, restaurativas, restitutivas in natura y compensatorias del daño ambiental conlleva la generación de 'pasivos ambientales'; y, en tercer lugar, que, a pesar de observar elementos de la responsabilidad civil extracontractual en el procedimiento sancionatorio ambiental, realmente lo que se busca a la luz de la normatividad ambiental, los principios ambientales, las disposiciones constitucionales y los avances jurisprudenciales, es el reconocimiento del concepto de daño ambiental y responsabilidad ambiental, que, si bien integra elementos importantes en diferente dimensión, va más allá de los esquemas puros de responsabilidad civil.

$\mathrm{Al}$ respecto, diferentes teóricos han advertido que la finalidad del derecho ambiental es precisamente garantizar a través de los instrumentos jurídicos la protección del ambiente como un derecho, bien e interés de carácter colectivo, defensa que puede resultar precaria desde las perspectivas civilistas, que se encuentran naturalmente enmarcadas en una lógica distinta. Para aclarar esto, se menciona la definición jurídica de 'contaminación' establecida en la Ley 23 de 1973 y en el Decreto 2811 de 1974 (Código Nacional de Recursos Naturales Renovables, CNRNR) como "la alteración del ambiente con sustancia o formas de energía puesta en él, por actividad humana y de la naturaleza, en cantidades, concentraciones o niveles capaces de interferir el bienestar y la salud de las personas, atentar contra la flora y la fauna, degradar la calidad del ambiente de los recursos de la nación o de los particulares". Conforme a esto, se concluye que la 'contaminación' está en un nivel inferior y, por lo tanto, puede definirse como la situación fáctica o factor causante de deterioro y del daño ambiental, que, si bien no es exclusiva, se suma a otras acciones para 
conformar el conjunto de efectos o impactos ambientales negativos que dan origen a la generación del daño ambiental (Briceño, 2009).

En cuanto al daño ambiental, desde el punto de vista dogmático, se ha identificado como la afectación, disminución o aminoración sobre el valor del bien o recurso natural y ambiental, desde lo cual se produce un desconocimiento de los derechos e intereses ambientales colectivos. Según Hinestrosa (1964, p.334), “daño es la lesión del derecho ajeno consistente en el quebrantamiento económico percibido, en la manera patrimonial sufrida por la víctima, a la vez que el padecimiento moral que la acongoja”. En los desarrollos de Bustamante Alsina (1972, p. 143), daño significa "el menoscabo que se experimenta en el patrimonio por el detrimento de los valores económicos que lo componen (daño patrimonial) y también la lesión a los sentimientos, al honor o a las afecciones legítimas (daño moral)”. De acuerdo con Tamayo (1998, p. 5), el "daño civil indemnizable es el menoscabo a las facultades jurídicas que tiene una persona para disfrutar de un bien patrimonial o extrapatrimonial" (p. 5). Y, para Henao (2009, p. 195), “el daño es la lesión —incluso la minoración no necesariamente económica- de un interés lícito, por su pérdida definitiva o por la amenaza en su goce pacífico". ${ }^{10}$

Un elemento que se reitera es que el daño puede estar ocasionado tanto en actividades ilegales o antijurídicas como en actividades amparadas legalmente, con lo cual también se incluyen los casos de abuso o desconocimiento de la autorización por parte de la autoridad ambiental, como las concesiones, permisos o licencias ambientales otorgadas (Uribe Vargas y Cárdenas Castañeda, 2010). ${ }^{11}$ Sobre este punto todavía existen vacíos sobre los ordenamientos jurídicos y la jurisprudencia, es decir, sobre los daños ambientales que son autorizados legalmente, pero que son objeto de medidas de control, manejo ambiental y seguimiento por parte de las autoridades ambientales a través de las autorizaciones en los actos administrativos, con lo cual el problema de daño ambiental se remitiría a los hechos en que los titulares de la autorización desconocen las medidas allí impuestas. En consecuencia, se observa claramente que el tema del daño ambiental se enmarca dentro de las instancias de las autorizaciones

10 Siguiendo las definiciones de la dogmática del derecho, que han sido compiladas por Amaya (2002), respecto a los avances teóricos de la responsabilidad por daños al ambiente.

11 Sobre el daño ambiental transfronterizo que puede ser originado incluso en actividades amparadas legalmente. 
ambientales como la licencia ambiental, pero también correlativamente desde las medidas de carácter sancionatorio.

Conforme a todo lo anterior, se observa el deber del Estado en cabeza de los órganos que lo conforman de tomar las medidas encaminadas a prevenir o evitar la generación del daño ambiental, y, de igual manera, garantizar los mecanismos para su compensación, indemnización y reparación integral. Es necesario advertir que la generación de un daño ambiental, además, puede extenderse más allá de las fronteras nacionales, por lo cual se exige a los Estados adoptar todas las medidas de forma diligente para evitarlo, y, de lo contrario, tomar medidas para su restitución a las condiciones anteriores cuando no se trate de daños irreversibles (Uribe Vargas y Cárdenas Castañeda, 2010).

Ahora bien, cuando se identifica la falta o ausencia de medidas preventivas, restaurativas o compensatorias efectivas, se produce como consecuencia la generación de pasivos y de deudas ambientales en tanto vínculo obligacional. Entonces, dada la relación de todos estos elementos, se puede analizar la interrelación entre 'contaminación', impactos y daños ambientales, la cual se determina del alcance de cada uno de los elementos frente a las medidas preventivas y compensatorias; cuando ya no es posible evitar, corregir o mitigar el impacto ambiental negativo, se desencadena la aparición del daño ambiental (ver figura 3.1) (Ávila, 2014).12

Por su parte, las 'medidas de compensación ambiental' surgen como acciones u obligaciones contraídas u originadas en la generación de daños efectuados sobre el ambiente, aunque diferenciadas en las instancias de autorización ambiental, respecto a los impactos ambientales, y los estadios que se derivan de la potestad sancionatoria del Estado por la comisión de un daño ambiental ocasionado. En esta medida, la falta de prevención y compensación del daño ambiental implica la aparición de la deuda o del pasivo ambiental, ${ }^{13}$ entendido jurídicamente

\footnotetext{
${ }^{12} \mathrm{El}$ daño es el elemento fáctico que se define como una fuente de la responsabilidad ambiental, que genera una obligación (de prevención, mitigación, reparación integral, medidas coercitivas, sanciones, de no repetición, etc.) y comporta las características de ser actualizable y exigible jurídicamente en el tiempo, pues en cada momento manifiesta sus efectos lesivos a la sociedad, en tanto no permite acceder, intercambiar, explotar, usar, consumir o aprovechar los elementos que conforman el ambiente y los recursos naturales (Ávila, 2014).

${ }^{13}$ Los 'pasivos ambientales' son deuda actualizable y exigible, surgida del vínculo obligacional de no dañar el ambiente con ocasión del uso, aprovechamiento, extracción, intercambio, consumo o explotación del ambiente y los recursos naturales (Ávila, 2014).
} 


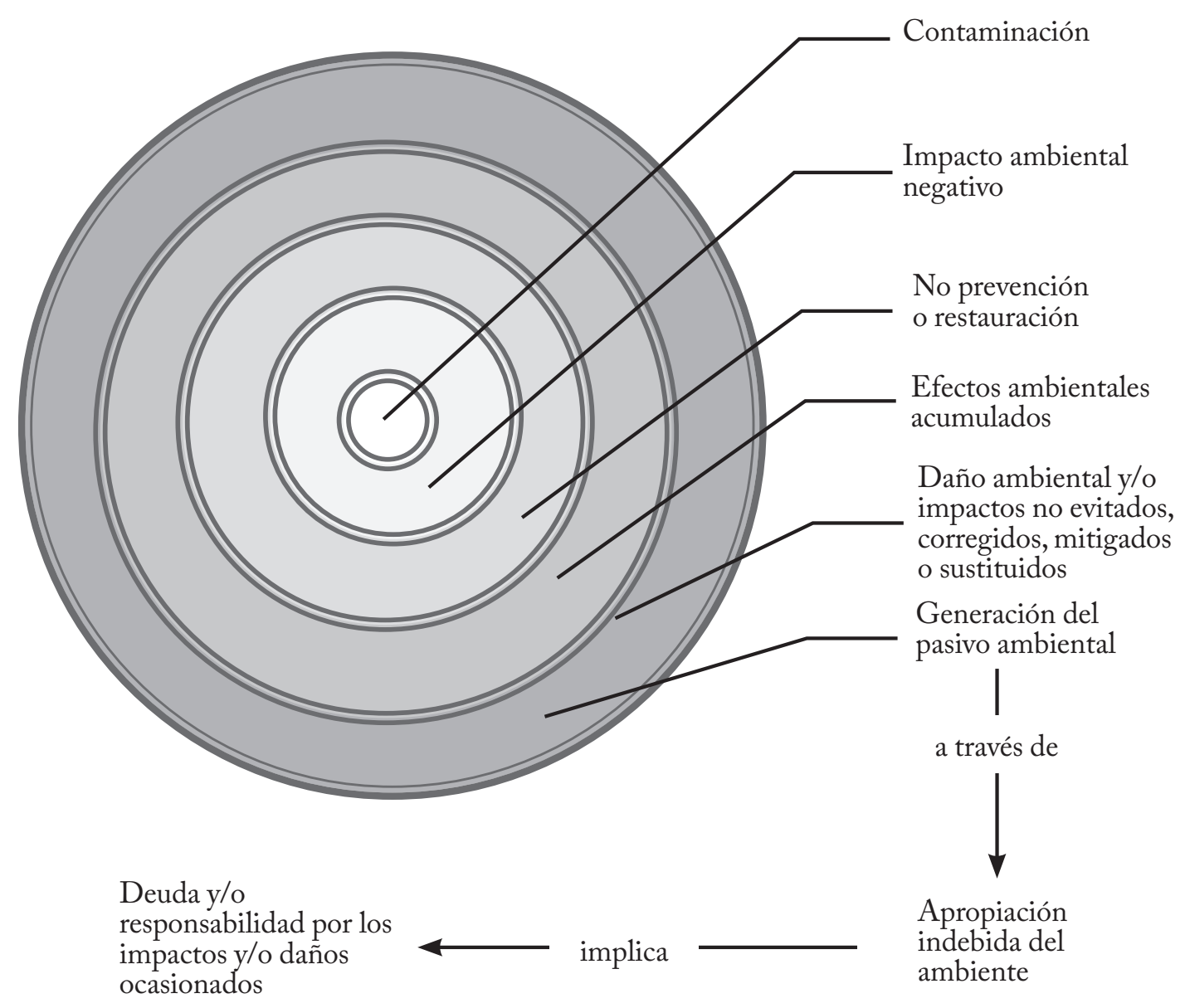

Figura 3.1. Esquema explicativo sobre la interrelación entre contaminación, impactos ambientales y daño ambiental (generación del pasivo ambiental)

Fuente: modificado a partir de Ávila (2014).

como el vínculo obligacional y elemento de la responsabilidad, que se refiere al acto por el cual una parte se obliga con otra a dar, hacer o no hacer alguna cosa. Dentro de la estructura de las obligaciones, se identifica la preexistencia de un sujeto activo, sujeto pasivo y un objeto (deuda o prestación), es decir que entre estos medie un vínculo jurídico creado por la ley o por un acto jurídico, en el que se imponga el deber de actuar. Entonces, se trata de un mandato por el cual una persona determinada debe realizar una prestación en provecho de otra, quien a su turno lo debe procurar (Ospina, 1987). ${ }^{14}$

${ }^{14}$ Refiere Ospina (1987) al contenido del artículo 1494 del Código Civil colombiano (crc, 1887), según el cual "las obligaciones nacen, ya del concurso real de las voluntades de dos o más personas, como en los contratos o convenciones; ya de un hecho voluntario de la persona que se obliga, como en la aceptación de una herencia o legado y en todos los cuasicontratos; ya a consecuencia de un hecho que ha inferido 
Es así como, en las fuentes de las obligaciones, el daño o menoscabo aparece como la consecuencia del incumplimiento de una obligación contractual o extracontractual o la falta de cuidado ante situaciones de riesgo, peligro o amenaza, de lo cual surge un juicio de 'responsabilidad'o reproche por la acción u omisión que dio lugar a que se materializara aquel, y que se identifica a través del 'nexo causal'. En este sentido, el daño corresponde a uno de esos elementos esenciales alrededor del cual gira todo el derecho frente a la responsabilidad, pues sin daño no se predicaría, y es, en consecuencia, presupuesto básico de la obligación de indemnizar y que se define como "todo hecho modificador de una realidad preexistente que afecta a un sujeto de derecho en su persona, su patrimonio o sus sentimientos" (Sarmiento García,2009). Sobre las categorías del daño, este se subdivide, desde el punto de vista dogmático y jurisprudencial, en: 1) el daño material o patrimonial, que a su vez se compone por (a) el daño emergente y (b) el lucro cesante; y 2) el daño inmaterial o extrapatrimonial, compuesto por (a) el daño moral, (b) el daño a la vida de relación y (c), el daño a la salud como categoría autónoma del daño inmaterial, diferenciando además entre el daño patrimonial, definido como la lesión a un interés económico, y el daño extrapatrimonial, entendido como la lesión a un interés no económico (Moisá y Misset, 2008). ${ }^{15}$

Ahora bien, en referencia a los elementos doctrinales de la responsabilidad civil que han sido desarrollados jurisprudencialmente, Mesa Cuadros (2001) aclara el alcance en referencia al daño y a la generación del 'pasivo ambiental' de la siguiente manera: i) la conducta o hecho de un sujeto (incumplimiento de la obligación o deber preexistente) que corresponde probar al peticionario o demandante; ii) un daño (perjuicio ocasionado a la víctima en razón a la conducta del sujeto), que requiere que sea cierto, directo (nexo de causalidad entre la conducta del sujeto y el daño), actual (previo a la solicitud de indemnización); excepcionalmente el daño futuro puede ser indemnizado, cuandoquiera que exista certeza de que ocurrirá; iii) nexo causal entre la conducta del sujeto y el

injuria o daño a otra persona, como en los delitos; ya por disposición de la ley, como entre los padres y los hijos de familia".

${ }^{15}$ Ahora bien, en Colombia el Consejo de Estado ha desarrollado una extensa línea jurisprudencial sobre la clasificación del daño, de la siguiente forma: 1) daño material, compuesto por (i) daño emergente y (ii) lucro cesante; y 2) daño inmaterial, en el que se incluyen (i) perjuicio moral, (ii) daños a bienes constitucionales y convencionales, (iii) daño a la salud derivado de perjuicios físicos o psicológicos y (iv) daño a la vida de relación (en razón a la relación de vida con los demás que está alterada drásticamente en sus condiciones de existencia por cambios fisiológicos, psicológicos o sociales) (CEc, 2006, 2007a, 2014a). 
daño; y iv) la culpa, como un elemento subjetivo que cualifica la conducta del agente, lo cual doctrinariamente también se define como aquel error de conducta en el cual no habría incurrido un hombre prudente y diligente (Mesa Cuadros, 2011).

Teniendo en cuenta todo lo anterior, surge un gran interrogante en relación con el daño ambiental sobre las limitantes de los conceptos y esquemas de la responsabilidad civil para afrontar el problema de los derechos e intereses colectivos involucrados. Una aproximación general indica que el esquema de responsabilidad civil se caracteriza naturalmente por una 'visión patrimonialista', resguardada en una férrea defensa del derecho de propiedad en un marco filosófico y jurídico que catapulta al individuo propietario como epicentro de la sociedad, para lo cual no resultaría suficiente para defensa de la noción de lo colectivo como corporeidad integral que representa los fines, la convivencia, el esfuerzo solidario y garantista generacional en la competencia humana (Briceño, 2009; Ávila, 2014).

En consecuencia, y siguiendo los desarrollos de Rodas Monsalve (1995), es necesario superar esa 'visión civilista' parcial, divisible y dependiente de los derechos y bienes ambientales, pues en realidad el ambiente comporta características de bien y derecho 'inmaterial, unitario y autónomo', que, por sus múltiples repercusiones, no puede reducirse a la responsabilidad entre dos sujetos que se disputan un derecho de carácter individual. En los mismos términos expresados por la evolución del derecho y la jurisprudencia comparada sobre el tema del daño ambiental, el autor advierte la necesidad de encontrar una nueva dirección de la responsabilidad fundada en una teoría objetiva bajo la premisa del papel del actor principal constituido por las 'víctimas', para lo cual resulta más adecuado concebir una teoría basada en los riesgos, amenazas y peligros que genera el contaminador con sus acciones u omisiones para la vida de los seres humanos y no humanos, y las afectaciones sociales y ecológicas, a fin de evitar los impactos negativos que se producen a manera de 'daños anónimos' difíciles de tratar en el esquema de responsabilidad actual. Del mismo modo, Mesa Cuadros (2011) y Ávila (2014) señalan la conveniencia de arribar a esquemas de responsabilidad objetiva en materia ambiental, en la cual baste únicamente con probar los efectos causados por el hecho dañino (por ejemplo, en la persistencia en el tiempo en que se presentan los efectos o en que aparecen y en la magnitud de la afectación, lo que desdibuja los esquemas de responsabilidad en cuanto resulta difícil individualizar al responsable). 
A pesar de la necesidad de este cambio, la Ley 1333 de 2009 (CRC), claramente ha optado por desarrollar la responsabilidad civil clásica, que se subdivide en contractual o extracontractual, teniendo esta última como la fuente de la gran mayoría de los daños perpetrados al ambiente, donde se aplica la fórmula tradicional que involucra, según lo establecido en el artículo 2341 del Código Civil, la demostración de la 'culpa aquiliana' (lo que debió hacer y no se hizo), acción dañosa, el daño y relación de causalidad entre aquella y este. Otro elemento importante en la teoría del daño ambiental se remite a los deberes de prevención, compensación o restitución y resarcimiento e indemnización que deben ser vistos a la luz de la Ley 1333 de 2009 (CRC). En este sentido, la responsabilidad implica la obligación de reparar el daño tratando de volver al estado anterior de las cosas cuando sea posible, para lo cual debe tomar medidas para 'restituir', 'compensar'y 'satisfacer' el ambiente afectado.

Teniendo en cuenta las discusiones anteriores, claramente la visión civilista-privatista está más enfocada en la indemnización económica monetaria o patrimonial del daño ambiental (que se puede considerar como un elemento adicional, pero no el único) que en la prevención de este, debido a que no repara en las medidas ex ante de prevención, mitigación o corrección, sino que se inclina por externalizar las cargas ambientales al resto de la sociedad, asumiendo de manera reducida ex post parte de los daños ocasionados con posibles indemnizaciones de carácter monetario (Daly y Cobb, 1997; Laffont, 2008). ${ }^{16}$ Aquí se vislumbra notoriamente uno de los mayores problemas en materia ambiental, el de la valoración ambiental económica, que responde a elementos mucho más complejos que la visión patrimonialista del esquema de responsabilidad civil (Ávila, 2014), es decir que, si bien se hace necesario integrar los valores monetarios, no son los únicos en perspectiva de una valoración y restablecimiento integral de los derechos transgredidos.

Analizando detenidamente el procedimiento sancionatorio ambiental, se diferencian tres dimensiones: 1) la 'sanción' como una consecuencia jurídica que busca el cambio de la conducta encaminada a modificar las actuaciones del responsable por haber infringido el ordenamiento jurídico y que puede

\footnotetext{
${ }^{16}$ Según Daly y Cobb (1997) y Laffont (2009), desde la economía, las 'externalidades'se definen como el comportamiento de un agente que afecta al bienestar de un tercero (de manera positiva o negativa), sin que este último haya elegido esa modificación, y sin que exista un precio o valor de la contraparte que lo compense. Un término asociado es el de 'des-economía'. Referido a las externalidades negativas, son aquellas que disminuyen el nivel de bienestar.
} 
contener diferentes obligaciones, incluyendo las de carácter pecuniario, por ejemplo, las multas a favor del Estado como castigo por haber incurrido en un acto indebido; diferente de 2) las medidas restaurativas y compensatorias que considere la autoridad ambiental dentro del procedimiento sancionatorio; distinto también de 3) la responsabilidad indemnizatoria y resarcitoria frente a los daños ocasionados a terceros en materia civil (daño ambiental impuro), en la cual se deberá incluir la compensación consistente en el pago por daños financieramente evaluables, debiendo incluir las pérdidas de los beneficios en el grado en que sean establecidos. Lo anterior ha sido aclarado precisamente por la jurisprudencia constitucional, de acuerdo con lo cual "las sanciones y las medidas preventivas en materia ambiental tienen finalidades de prevención, correctivas y compensatorias, pero no resarcitorias o indemnizatorias. De ahí que el fundamento jurídico de la responsabilidad civil es diferente a la administrativa ambiental, no siendo posible equiparar el modelo de culpabilidad exigida" (ccc, 2010b).

En este sentido, claramente se indica que no es posible asimilar la responsabilidad ambiental con la responsabilidad civil, más cuando esta última está diseñada ontológicamente bajo un enfoque individual o contractual que dista de la conceptualización de bien común o un derecho e interés colectivo desde una visión patrimonialista pura (ver tabla 3.1) (Briceño, 2009).

Tabla 3.1. Comparación entre teorías de responsabilidad civil y ambiental para el tratamiento de pasivos ambientales

\begin{tabular}{|l|l|}
\hline \multicolumn{1}{|c|}{ Responsabilidad civil privatista } & \multicolumn{1}{c|}{ Responsabilidad ambiental } \\
\hline $\begin{array}{l}\text { Reconocimiento de responsabilidad mínima del } \\
\text { daño ambiental o incapacidad de reconocimiento } \\
\text { del daño. }\end{array}$ & $\begin{array}{l}\text { Responsabilidad ampliada, compartida, pero di- } \\
\text { ferenciada frente a la contaminación, los pasivos } \\
\text { ambientales y las deudas ambientales. }\end{array}$ \\
\hline $\begin{array}{l}\text { Tendencia al desconocimiento sobre el pasivo } \\
\text { ambiental ocasionado por modelo privado de } \\
\text { rentabilidad mediante generación de externali- } \\
\text { dades negativas. }\end{array}$ & $\begin{array}{l}\text { Reconocimiento del pasivo ambiental acumulable } \\
\text { (responsabilidad histórica) por el uso, aprovecha- } \\
\text { miento, explotación, consumo, apropiación e inter- } \\
\text { cambio indebido e injustificado sobre el ambiente. }\end{array}$ \\
\hline $\begin{array}{l}\text { Desconocimiento de los derechos intergeneracio- } \\
\text { nales por la visión a corto plazo. }\end{array}$ & $\begin{array}{l}\text { Visión a largo plazo y reconocimiento de los dere- } \\
\text { chos intergeneracionales a través de la prevención } \\
\text { de los pasivos ambientales. }\end{array}$ \\
\hline $\begin{array}{l}\text { Visión compensatoria mínima sustentada de ma- } \\
\text { nera exclusiva en valores monetarios. }\end{array}$ & $\begin{array}{l}\text { Reparación integral sustentada en la pluralidad de } \\
\text { valores adicionales a los valores monetarios sobre } \\
\text { las víctimas y medidas adicionales de carácter } \\
\text { resarcitorio. }\end{array}$ \\
\hline
\end{tabular}




\begin{tabular}{|l|l|}
\hline $\begin{array}{l}\text { Aplicación de justicia procedimental mínima se- } \\
\text { gún acuerdo entre las partes en el proceso. }\end{array}$ & $\begin{array}{l}\text { Posición garantista procedimental frente a los } \\
\text { derechos ambientales colectivos. }\end{array}$ \\
\hline $\begin{array}{l}\text { Teoría de responsabilidad subjetiva a través de la la } \\
\text { comprobación del daño, el hecho y un nexo causal } \\
\text { entre los dos elementos anteriores. }\end{array}$ & $\begin{array}{l}\text { Necesidad de aplicación de responsabilidad obje- } \\
\text { tiva, sin vincular el factor culpabilidad, a través de } \\
\text { la presunción entre el hecho generador y el daño } \\
\text { ocasionado. }\end{array}$ \\
\hline $\begin{array}{l}\text { Perspectiva de incremento de la deuda ambiental } \\
\text { por rentabilidad inmediata o exigencia del 'pago } \\
\text { de las deudas ambientales. }\end{array}$ & $\begin{array}{l}\text { Demanda de la irrupción o terminación de la } \\
\text { deuda ecológica y ambiental a través de la rei- } \\
\text { vindicación de la justicia ambiental redistributiva } \\
\text { entre sectores de la sociedad. }\end{array}$ \\
\hline
\end{tabular}

Fuente: tomado de Ávila (2014).

Por lo tanto, dichas medidas restaurativas y compensatorias pueden estar referidas a disposiciones para integrar el restablecimiento frente al daño ecológico y social, incluyendo medidas diversas para la descontaminación de los ecosistemas e, incluso, el arrepentimiento público expresado por la comisión del daño, a fin de recuperar la confianza legítima que ha sido quebrantada de la sociedad frente al Estado. Todas estas medidas se encaminan a la misma dirección de las observaciones sobre los problemas de valoración ambiental, reconociendo que el ambiente excede la visión de sustitución entre valores en términos económicos y monetarios del capital natural y el capital hecho por humanos (man-made capital), por la imposibilidad de no poder traducir todo en unidades de dinero o de renta de capital, por lo cual se indica la preocupación esencial con miras a garantizar la conservación, la sostenibilidad y los valores intrínsecos e inmanentes del ambiente y la naturaleza para las presentes y futuras generaciones (Martínez Alier, 1995, 2002). ${ }^{17}$ Todo esto también llama a la reflexión de los diferentes actores en la necesidad o conveniencia de esencialmente prevenir el daño ambiental como valor supremo bajo esquemas de responsabilidad ambiental por observar en las actividades históricas de uso, aprovechamiento, explotación, extracción, consumo e intercambio del ambiente y los recursos naturales.

\section{Conclusiones}

De acuerdo con la jurisprudencia y los desarrollos teóricos, el daño ambiental es fuente de responsabilidad y está definido jurídicamente como la afecta-

\footnotetext{
${ }^{17}$ En ambos trabajos, Martínez Alier (1995) hace referencia a la 'sustituibilidad' entre capital natural y capital artificial (man-made capital), así como al proceso de 'monetización de la naturaleza'.
} 
ción, disminución o aminoración sobre el valor del bien o recurso natural y ambiental, que conduce al desconocimiento de los derechos e intereses ambientales colectivos, generado tanto en actividades ilegales o antijurídicas como en actividades amparadas legalmente, que, a pesar de estar precedidas de una autorización otorgada por la autoridad ambiental (e.g., concesiones, permisos o licencias ambientales), implican casos de abuso o desconocimiento por parte de su titular.

En el ordenamiento jurídico interno y en el DAI, se observan dos tipos de medidas frente al daño ambiental: la primera es el deber del Estado de cara a la planificación del manejo y aprovechamiento de los recursos naturales, a fin de garantizar su desarrollo sostenible, su conservación, restauración o sustitución, para lo cual se le exige prevenir y controlar los factores de deterioro ambiental, imponer las sanciones legales y exigir la reparación de los daños causados, respondiendo además por los daños ambientales antijurídicos ocasionados en el ejercicio de sus actividades; y la segunda, la responsabilidad de los particulares frente al daño ambiental y el uso inadecuado de los elementos ambientales. Del mismo modo, se exige al Estado asumir su responsabilidad internacional por daños transfronterizos ocasionados a otros países. Y garantizar a nivel interno los procedimientos administrativos y judiciales encaminados a reparar el daño, así como desarrollar la legislación nacional relativa a la responsabilidad y la indemnización respecto de las víctimas de la contaminación y otros daños ambientales.

Dentro de la jurisprudencia comparada, se han identificado notables progresos de la conceptualización del daño ambiental que van más allá de las fases de la responsabilidad civil, que, si bien aporta elementos importantes, se considera insuficiente para abordar el tema desde una perspectiva de valoración, restablecimiento o reparación integral del daño más allá de una visión patrimonialista y/o monetaria. Por otra parte, se requiere que se configuren posiciones cada vez más inclusivas y garantistas con planteamientos sobre las problemáticas ambientales que incluyan una perspectiva ecológica asociada a los bienes afectados, integrando a su vez aspectos sociales y elementos efectivos de protección, lo que, en otras palabras, implica una visión integral de los problemas de valoración ambiental del daño. En la jurisprudencia internacional, se han incluido elementos sociales que sobrepasan la apreciación del simple daño ecológico en las medidas de compensación relacionadas con valores y principios sociales fragmentados 
(por ejemplo, la 'confianza legítima' de la sociedad y las comunidades frente a las medidas del Estado).

En la jurisprudencia nacional, también se han visto avances en el mismo sentido, que van desde la diferenciación entre el 'daño ambiental puro', definido como todos los perjuicios que se causan directamente al ambiente, con independencia de los derechos subjetivos de las personas que se vean afectadas, y el 'daño ambiental impuro', entendido como aquel que, pese a existir una afectación de carácter colectivo, recae de manera exclusiva sobre perjuicios de índole particular, "daños individuales que son la consecuencia o el reflejo de la lesión ambiental [...] cuyo derecho no es de corte subjetivo-colectivo, sino subjetivo-individual". En la jurisprudencia constitucional, se relaciona el daño ambiental tanto al instrumento de manejo y control para prevenir, mitigar y corregir sus efectos, como al procedimiento sancionatorio ambiental. En este último, se aclara la función sancionatoria y medidas preventivas del artículo 4º de la Ley 1333 de 2009 y la diferencia entre la sanción (artículo 40 ibíd.) y el cumplimiento de las medidas de compensación y restauración del 'daño' o el 'impacto' cuando la autoridad ambiental competente estime necesario (artículo 31 ibíd.), frente a lo cual concluye que "las sanciones y las medidas preventivas en materia ambiental tienen finalidades de prevención, correctivas y compensatorias, pero no resarcitorias o indemnizatorias". Además, se hace énfasis desde la interpretación constitucional en las medidas de prevención, las cuales están ligadas a los principios ambientales de precaución y prevención, que además tienen gran connotación frente a los daños graves e irreversibles sobre el ambiente. $Y$ en cuanto a las medidas de compensación, la jurisprudencia constitucional manifiesta el deber de establecer una restitutio in natura del daño al activo natural afectado, por medio de medidas necesarias para volver al estado anterior las cosas cuando sea posible.

Desde el punto de vista teórico, se diferencia entre la contaminación y los demás impactos ambientales como acciones y situaciones fácticas que originan el daño ambiental. Se afirma además que la falta de prevención y compensación del daño ambiental conlleva la aparición de la deuda y del pasivo ambiental, entendido jurídicamente como el vínculo obligacional y elemento de la responsabilidad, en el que se refiere al acto por el cual una parte se obliga con otra a dar, hacer o no hacer alguna cosa, para el caso vinculadas al ejercicio 
de actividades inadecuadas ${ }^{18}$ por el uso, aprovechamiento, explotación, extracción, consumo e intercambio cuidadoso del ambiente y los recursos naturales.

Finalmente, se podría decir que los desarrollos anotados indican una tendencia hacia la superación de la 'visión patrimonialista' parcial, divisible y dependiente de los derechos y bienes ambientales de la perspectiva civilista, enfocada naturalmente a la indemnización económica monetaria o patrimonial de cierta parte del daño ambiental, más que en la prevención de este, auspiciada en ciertos eventos por la lógica de externalizar los costos ambientales al resto de la sociedad. Frente a esto, como bien lo ha establecido el ordenamiento jurídico, la jurisprudencia y el desarrollo dogmático, se observa la inconveniencia de asimilar la responsabilidad ambiental con la responsabilidad civil, definiendo la primera como una perspectiva de responsabilidad ampliada y diferenciada, con reconocimiento acumulable del pasivo ambiental, desde una visión a largo plazo, que demanda la reparación integral sustentada en la pluralidad de valores adicionales a los patrimoniales y/o monetarios, reconociendo el derecho de las víctimas y carácter resarcitorio con garantía plena de los derechos ambientales colectivos y que bien pueden operar como desincentivos que conduzcan a frenar los daños y pasivos ambientales.

La apuesta, bajo un visión integrativa de la sociedad, la institucionalidad, la empresa, los expertos y la academia, en un momento en que se perciben las afectaciones ambientales, radica en esencialmente prevenir o evitar impactos, daños y pasivos ambientales, articulando el desarrollo de las actividades económicas y el derecho al desarrollo de los pueblos, con el uso cuidadoso del ambiente y el aprovechamiento de los recursos naturales renovables, donde no haya perdedores, en tanto todos en su conjunto seamos ganadores.

\section{Bibliografía}

Amaya, O. (2002). Responsabilidad por daños al medio ambiente en Colombia. Memorias viII Congreso Venezolano de Derecho Ambiental: Mecanismos y Medidas Jurídicas en Defensa del Ambiente, Camino a la Cumbre sobre Desarrollo Sostenible, Universidad Metropolitana, Caracas.

\footnotetext{
${ }^{18}$ Por ejemplo, no observar los estándares o recomendaciones nacionales e internacionales o la elaboración y evaluación defectuosa de los estudios ambientales como un ejercicio eminentemente predictivo de los impactos y daños ambientales.
} 
Asamblea Nacional Constituyente de Colombia (ANC). (1991). Constitución Politica de Colombia. Bogotá, D.C.: ANC.

Ávila, T.S. (2014). Principios, derechos y pasivos ambientales: un estudio de caso sobre contaminación por residuos peligrosos en Bogotá D.C. (Colombia) (Tesis de maestría, Universidad Nacional de Colombia, Bogotá, D.C., Colombia).

Briceño, A. M. (2009). Aproximación a los conceptos de daño ecológico y de daño ambiental. En A.M. Briceño et al. (Comps.), Daño ambiental II (pp. 15-74). Bogotá, D.C.: Universidad Externado de Colombia.

Bustamante Alsina,J.(1972). Teoría general de la responsabilidad civil (4a ed., 1983). Buenos Aires: Abeledo Perrot.

Consejo de Estado de Colombia (CEc). (2000). Sentencia acción popular caso Fundación Biodiversidad vs. Dagma [Rad. Exp.Ap-031 (abril 13 de 2000)]. Bogotá, D.C.: CEC.

Consejo de Estado de Colombia (CEc). (2004). Sentencia acción de grupo caso Hernández Santacruz vs. Ministerio de Ambiente y Ecopetrol [Rad. Exp. AG 52001-23-31-000-2002-00226-01 (mayo 13 de 2004)]. Bogotá, D.C.: CEC.

Consejo de Estado de Colombia (CEc). (2006). Sentencia acción de reparación directa del 4 de diciembre de 2006 [caso Giraldo Chaves vs. Ministerio de Transporte et al., Rad. Exp. ARD 52001-23-31-000-1996-0763301(15351)]. Bogotá, D.c.: cEC.

Consejo de Estado de Colombia (CEc). (2007a). Sentencia acción de grupo del 15 de agosto de 2007 [caso Ordóñez Sandoval et al. vs. Ministerio de Defensa et al., Rad. Exp. AG. $190012331000200300385-01]$. Bogotá, D.c.: CEC.

Consejo de Estado de Colombia (CEC).(2007b). Sentencia acción popular del 22 de febrero de 2007 [caso Colina vs. Ministerio de Ambiente et al., Rad. Exp. AP. 52001-23-31-000-2004-00092-01]. Bogotá, D.C.: CEC.

Consejo de Estado de Colombia (CEc). (2009). Sentencia acción popular del 4 de junio de 2009 [caso Fundación para la Defensa del Interés Público vs. Instituto de Desarrollo Urbano de Bogotá, Rad. Exp. 25000-23-25-0002002-00093-01(AP)]. Bogotá, D.C.: CEC.

Consejo de Estado de Colombia (cEc). (2011). Sentencia del 10 de marzo de 2011 [acción de nulidad contra los artículos $1^{\circ}, 2^{\circ}$ y $3^{\circ}$ del Decreto 1631 de 2006]. Bogotá, D.c.: cEC. 
Consejo de Estado de Colombia (CEC). (2012). Sentencia del 10 de noviembre de 2012 [caso Buitrago Quinteros y otros vs. Distrito Capital de Bogotá, Rad. Exps. 25000232600019990002 04 y 2000-00003-04]. Bogotá, D.C.: CEC. Consejo de Estado de Colombia (cEc). (2013). Sentencia acción popular del 26 de noviembre de 2013 [caso Maldonado y otros vs. FIIC]. Bogotá, D.C.: CEC. Consejo de Estado de Colombia (CEC). (2014a). Documento ordenado con el fin de recopilar la línea jurisprudencial y establecer los criterios unificados para la reparación de los perjuicios inmateriales [Acta del 28 de agosto de 2014]. Bogotá, D.C.: CEC.

Consejo de Estado de Colombia (CEc). (2014b). Sentencia acción de reparación directa del 20 de febrero de 2014 [caso Medina vs. Ministerio de Defensa y otros, Rad. Exp. 41-001-23-31-000-2000-02956-01 (29028)]. Bogotá, D.C.: CEC.

Corte Constitucional de Colombia (ccc). (1998). Sentencia C-320 de 1998: revisión de constitucionalidad por objeciones presidenciales al proyecto de Ley 235 de 1996 Senado y 154 de 1996 Cámara, "por el cual se establece el seguro ecológico, se modifica el Código Penal y se dictan otras disposiciones". Bogotá, D.c.: ccc.

Corte Constitucional de Colombia (ccc). (1999). Sentencia C-035 de 1999 [demanda pública de inconstitucionalidad contra Ley 99 de 1993, artículo 56]. Bogotá, D.c.: ccc.

Corte Constitucional de Colombia (ccc). (2004). Sentencia T-294 de 2004: acción de tutela de Rafael Vergara Navarro contra el Juzgado $6^{\circ}$ Civil del Circuito de Cartagena y la Sala Civil del Tribunal Superior de Cartagena. Bogotá, D.C.: ccc.

Corte Constitucional de Colombia (ccc). (2010a). Sentencia C-401 de 2010: demanda de inconstitucionalidad contra el artículo 10 de la Ley 1333 de 2009. Bogotá, D.c.: ccc.

Corte Constitucional de Colombia (ccc). (2010b). Sentencia C-595 de 2010: demanda de inconstitucionalidad contra el parágrafo del artículo $1^{\circ}$ y el parágrafo $1^{\circ}$ del artículo $5^{\circ}$ de la Ley 1333 de 2009, "por la cual se establece el procedimiento sancionatorio ambiental y se dictan otras disposiciones". Bogotá, D.C.: ccc.

Corte Constitucional de Colombia (Ccc). (2010c). Sentencia C-703 de 2010: demanda de inconstitucionalidad parcial contra la Ley 1333 de 2009. Bogotá, D.C.: cCc. 
Corte Constitucional de Colombia (ccc). (2010d). Sentencia T-851 de 2010 [caso Benítez Coy vs. Alcaldía Municipal de Barbosa]. Bogotá, D.c.: ccc. Corte Constitucional de Colombia (ccc). (2011). Sentencia C-632 de 2011: demanda de inconstitucionalidad contra los artículos 31 y 40 (parcial) de la Ley 1333 de 2009,"por la cual se establece el procedimiento sancionatorio ambiental y se dictan otras disposiciones”. Bogotá, D.c.: ccc.

Corte Constitucional de Colombia (ccc). (2012a). Sentencia C-746 de 2012 [demanda de inconstitucionalidad contra el numeral 9 del artículo 52 de la Ley 99 de 1993]. Bogotá, D.c.: ccc.

Corte Constitucional de Colombia (ccc). (2012b). Sentencia T-693 de 2012 [caso Unión Temporal Desarrollo Vial del Valle del Cauca y Cauca vs. Ministerio de Ambiente y Desarrollo Sostenible]. Bogotá, D.c.: ccc.

Corte Europea de Derechos Humanos (CEDH). (1993). Sentencia del 25 de noviembre de 1993 [caso Zander vs. Suecia, No 45/1992/390/468]. Estrasburgo: CEDH (versión original en inglés).

Corte Europea de Derechos Humanos (CEDH). (1994). Sentencia del 9 de diciembre de 1994 [caso López Ostra vs. España, No 16798/90]. Estrasburgo: CEDH (versión original en inglés).

Corte Europea de Derechos Humanos (cEDH). (2004). Sentencia del 10 de noviembre 2004 [caso Taskin y otros contra Turquía, No 46117/99]. Estrasburgo: CEDH (versión original en inglés).

Corte Europea de Derechos Humanos (CEDH). (2005a). Sentencia del 9 de junio de 2005 [caso Fadeyeva vs. Rusia, No 55723/00]. Estrasburgo: CEDH (versión original en inglés).

Corte Europea de Derechos Humanos (cEDH). (2005b). Sentencia del 12 de julio de 2005 [caso Okyay y otros vs. Turquía]. Estrasburgo: CEDH (versión original en inglés).

Corte Europea de Derechos Humanos (CEDH). (2006). Sentencia del 2 de noviembre de 2006 [caso Giacomelli vs. Italia, No 59909/00]. Estrasburgo: CEDH (versión original en inglés).

Corte Internacional de Justicia (cIJ). (1996). Advisory opinion of 8 July 1996: the legality of the Threat or Use of Nuclear Weapons. La Haya: CIJ.

Corte Internacional de Justicia (cIJ). (1997). Judgment of 25 September of 1997: case concerning the Gabcikovo-Nagymaros project: Hungary-Slovakia. Reports of judgements, advisory opinions and orders. 692. La Haya: cIJ. 
Corte Nacional del Ecuador (CNE). (2013). Sentencia de casación civil del 12 de noviembre de 2013 [caso Salazar y otros vs. Chevron Corp., Juicio No 174-2012]. Quito: cNE.

Corte Provincial de Sucumbíos (cPs). (2012). Sentencia del 3 de enero de 2012 [caso Salazar y otros vs. Chevron Corp.]. Nueva Loja: cPs.

Corte Suprema de Justicia de Colombia (csJ). (1976). Sentencia de casación civil instaurado por Hilanderías Medellín S.A. vs. Compañía de Productos Químicos Nacionales-Sulfácidos S.A. [Gaceta Judicial 2393, 1976: 128, 129, 130, 131 (abril 30 de 1976)]. Bogotá, D.c.: csJ.

Corte Suprema de Justicia de Colombia (CsJ). (1999). Sentencia de casación civil del 25 de octubre de 1999 [caso Acosta vs. Gases del Caribe S.A.]. Bogotá, D.C.: csJ.

Corte Suprema de Justicia de Colombia (csJ). (2011). Sentencia de casación civil del 16 de mayo de 2011 [caso Ampeatum vs. Mesta Shipping Company y otros, Rad. Exp. 52835-3103-001-2000-00005-01]. Bogotá, D.c.: csJ.

Daly, H. E., \& Cobb, J. B. Jr. (1997). Para el bien común: reorientando la economía hacia la comunidad, el ambiente y el futuro sostenible. Bogotá: Fondo de Cultura Económica.

Geneviève, V., \& Patrice, J. (1998). Traité de droit civil: Les conditions de la responsabilité. Paris: LGDJ.

Gómez-Robledo, A. (1992). Responsabilidad internacional por daños transfronterizos. México, D.F.: Universidad Nacional Autónoma de México (UnAM).

Henao, J. C. (2009). De la importancia de concebir la amenaza y el riesgo sobre derechos ambientales como daño cierto. En A.M. Briceño et al. (Comps.) Daño ambiental II. Bogotá, D.C.: Universidad Externado de Colombia.

Hinestrosa, F. (1964). Derecho civil: obligaciones. Bogotá, D.C.: Universidad Externado de Colombia.

Laffont, J. J. (2008). Externalities. En S. N. Durlauf \& L. E. Blume (Eds.), The new palgrave dictionary of economy. Recuperado de http://www.dictionaryofeconomics.com

Martínez Alier,J. (1995). Curso básico de economía ecológica. México, D.F.: PNUmA.

Martínez Alier, J. (2002). The environmentalism of the poor: a study of ecological conflicts and valuation. Radstock: EE Publishing.

Mesa Cuadros, G. (2011). Análisis constitucional y legal para la gestión de pasivos ambientales en el sector de hidrocarburos. En G. Mesa Cuadros (Ed.), 
Elementos para una teoria de la justicia ambiental y el estado ambiental de derecho (pp. 233-250). Bogotá, D.C.: Universidad Nacional de Colombia. Moisá, B., \& Misset, L. (2008). Daño extrapatrimonial (o moral) a las personas jurídicas. Revista Jurídica del Perú, 87, 303-363.

Rodas Monsalve, J. C. (1995). Fundamentos constitucionales del derecho ambiental colombiano (4a reimp., 1999). Bogotá, D.C.: Universidad de los Andes, Tercer Mundo.

Sarmiento García, M. G. (2009). Estudios de responsabilidad civil(2a ed.). Bogotá, D.C.: Universidad Externado de Colombia.

Tamayo,J.(1998). De la responsabilidad civil. IV.De los perjuicios y su indemnización (2a ed., 1999). Bogotá, D.C.: Temis.

Trail Smelter Arbitral Tribunal (тsAT). Laudo arbitral caso Estados Unidos vs. Canadá, Trail Smelter Case (11 de marzo de 1941) (ed. en inglés, 2006).

Uribe Vargas, D., \& Cárdenas Castañeda, F. A. (2010). Derecho internacional ambiental. Bogotá, D.C.: Fundación Universitaria Jorge Tadeo Lozano. 



\section{Daños por contaminación de hidrocarburos persistentes en el mar y su cobertura en el derecho civil colombiano}

Jouline Ropero Patarroyo*

\section{Introducción}

El daño, como suceso connatural a la sociedad de riesgo en la que vivimos, sigue siendo una preocupación colectiva y de las normas que nos rigen. Ante la posibilidad que tenemos todos de dañar o ser dañados (Hinestrosa, 2007, p. 13), el daño es un asunto cuyo interés se renueva con el tiempo, dado que sigue a la orden del día como evento de probable acaecimiento en cualquiera de los ámbitos en los que nos desarrollamos como individuos y como sociedad.

Uno de estos ámbitos es el transporte marítimo de hidrocarburos a través de embarcaciones. Bien sabido es que, dada la ausencia de ductos transnacionales y transcontinentales que permitan llevar los hidrocarburos de los países productores hacia los consumidores, el transporte marítimo de estas sustancias por medio de navíos sigue siendo el principal mecanismo para satisfacer esta necesidad a nivel mundial.

En ese sentido, la constante actividad transportadora implica múltiples riesgos, no solamente para las personas que intervienen en ella, sino también para el medio del que se valen en su ejecución. Uno de estos riesgos es el derrame de hidrocarburos en el mar, que puede causar su contaminación y la de los ecosistemas que en él se hallan, así como la lesión de los intereses personales de quienes se relacionan con tal medio.

\footnotetext{
* Abogada de la Universidad Externado de Colombia; especialista en Responsabilidad y Daño Resarcible de la Universidad Externado de Colombia; magíster en Derecho de Daños de la Universidad de Girona (España). Correo electrónico: joulineropero@gmail.com
} 
El derecho de daños no ha sido ajeno a esta realidad, sino que paralelamente a los hechos dañosos de este tipo ha desarrollado contenidos normativos que pretenden hacer frente a los daños causados, a fin de repararlos. Este es el caso del llamado daño ecológico puro, que en el ámbito colombiano es denominado daño ambiental puro, cuyo desarrollo conceptual y su resarcimiento en la práctica colombiana siguen hoy en ciernes, debido a los retos conceptuales que representa para la tradición iuscivilista.

Esta circunstancia podría explicar la escasa atención que el medio ambiente ha recibido del derecho civil en general - y de la responsabilidad civil en especial- (Ruda, 2008, pp. 31-43) para atender asuntos que, según se sostiene, no están dentro de su órbita. Claro está, dicha situación es consentida por operadores judiciales y doctrinantes a partir de argumentos teóricos que se los permitiría.

Así, además de la dificultad que representa en cualquier ámbito del derecho lograr una definición pacífica de medio ambiente - pues es un concepto abstracto y difícil de determinar por su dinamismo (Casas, 2002, p. 140)—, el derecho civil encuentra dificultades adicionales que parten de su enfoque antropocéntrico e individualista, propio de la época liberal en el que se dio su apogeo y adopción entre nosotros.

Es palmario que tradicionalmente la doctrina civilista ha tomado únicamente la lesión de bienes jurídicos individuales como punto de partida para una definición del daño, sin abordar de manera suficiente los derechos de la colectividad, en tanto ellos representarían un asunto público y no privado. A ello se suma la ya arraigada idea según la cual la razón de ser de la responsabilidad civil ha sido, históricamente, la lesión al individuo y no al medio ambiente en sí mismo considerado. ${ }^{1}$

En este orden de ideas, el daño ha sido definido a partir de la existencia de una víctima individual que lo padece, sin que se conciba de forma despersonalizada. Bajo esa premisa, para el derecho de la responsabilidad civil, el daño es concebido a partir de la existencia de una víctima posible, que sería el individuo (persona), circunstancia que pone en evidencia el contraste entre el carácter colectivo que se ha reconocido al menoscabo del medio ambiente y

\footnotetext{
${ }^{1} \mathrm{Al}$ respecto, la responsabilidad civil extracontractual se ha desarrollado a partir de la lex Aquilia, que sancionaba el daño (iniuria) cometido dentro de un contexto bilateral en el que un individuo lesiona el patrimonio de otro (damnum iniuria datum) (Koteich, 1993).
} 
el carácter antropocéntrico e individualista de la responsabilidad civil, tradicionalmente concebida.

De esta manera, se ha considerado que la existencia de una víctima individual del daño constituye un requisito indispensable para la responsabilidad civil, en tanto el daño debe ser personal, cierto y directo (Henao, 2009,pp. 189-204). Así, siendo característico del daño el hecho de que hubiese recaído directamente sobre una determinada persona (reclamante) y que pueda establecerse con certeza su magnitud, no sería posible concebir la existencia de un daño como el ambiental, que a todas luces es impersonal, que lesiona intereses difuminados en un colectivo y cuya determinación (cuantificación o certeza de este) representa un gran reto para cualquiera que lo pretenda establecer.

Esta es la razón principal por la que ha habido debate acerca de si es o no la responsabilidad civil el mecanismo idóneo para reparar este tipo de daños, pues la cuestión plantea retos teóricos que en el caso de la contaminación marina de hidrocarburos también están presentes.

Conviene entonces examinar el contenido de la actual regulación de la responsabilidad civil por daños derivados de la contaminación marina de hidrocarburos persistentes ${ }^{2}$ en nuestro ordenamiento, a fin de observar y analizar si este resulta suficiente para resarcir la totalidad de daños que se generan a partir de estos sucesos, asunto que constituirá la problemática central del presente artículo.

\subsection{Regulación de la responsabilidad civil por daños derivados de la contaminación marina por hidrocarburos en Colombia}

Colombia ha adoptado instrumentos internacionales especializados que regulan la responsabilidad civil en hipótesis de derrames de hidrocarburos persistentes al mar. Esto corresponde al hecho de que se trata de una problemática que trasciende fronteras y que puede involucrar los intereses de cualquier país cercano al infortunio.

Concretamente, la regulación en comento se ha efectuado a través de foros y convenciones internacionales liderados por la Organización Marítima

\footnotetext{
${ }^{2}$ Por hidrocarburos persistentes se entienden aquellos que sean de origen mineral, como crudos de petróleo, fueloil, aceite diésel pesado y aceite lubricante, ya se transporten estos a bordo de un buque como carga o en los depósitos de combustible líquido de ese buque (artículo I.5 del Convenio Internacional sobre Responsabilidad Civil de 1992).
} 
Internacional (OMI), la agencia especializada de las Naciones Unidas (con sede en Londres) que se ocupa de mejorar la seguridad del transporte marítimo dedicado al comercio internacional y de prevenir la contaminación de los mares causada por los buques.

Inicialmente, en el contexto internacional, se crearon dos convenios para regular la materia: el Convenio de 1969 sobre Daños Causados por Contaminación Marina por Hidrocarburos (1969 Civil Liability Convention) y el Convenio de 1971 (1971 Fund Convention) sobre Constitución de un Fondo Internacional de Indemnización por la Contaminación de Hidrocarburos, elaborados con motivo del accidente del Torrey Canyon en 1967.3 Ambos convenios fueron adoptados en nuestro ordenamiento jurídico mediante la Ley 55 de 1989.

Posteriormente, tales instrumentos fueron modificados por dos protocolos en 1992. Los convenios con sus enmiendas constituyen la principal regulación internacional sobre el tema y se conocen, respectivamente, como el Convenio de Responsabilidad Civil de 1992 (1992 Civil Liability Convention, CLC) y el Convenio del Fondo de $1992^{4}$ (1992 Fund Convention, Fund), que actualmente componen el régimen internacional de indemnización de los daños ocasionados por la contaminación marina por hidrocarburos. Tal normatividad fue acogida por Colombia mediante la expedición de la Ley 523 de 1999.

Con la finalidad de conocer más el sistema jurídico bajo estudio, es preciso señalar de cada convenio lo siguiente:

4.1.1. El cLC ofrece un primer nivel de indemnización (first tier), en virtud del cual toda persona que haya sufrido daños por contaminación en un Estado parte del convenio puede promover reclamaciones de indemnización por daños debidos a la contaminación ocasionada por las fugas o descargas de hidrocarburos persistentes al propietario inscrito o el asegurador del buque de donde provenían los hidrocarburos que causaron el daño (Fondo Internacional de Daños debidos

${ }^{3}$ Buque que encalló cerca de las islas Sorlingas contaminando las costas del Reino Unido y de Francia.

${ }^{4}$ Los convenios de 1992 entraron en vigor el 30 de mayo de 1996. El Convenio del Fondo de 1971 dejó de estar en vigor el 24 de mayo de 2002, cuando el número de Estados miembros del Fondo de 1971 se redujo a menos de 25, dejándolo en camino a su liquidación. 
a Contaminación por Hidrocarburos, 2013). De este primer nivel de indemnización, se destaca lo siguiente:

4.1.1.1. Se establece la canalización de la responsabilidad civil en el propietario del buque. ${ }^{5}$ Así, entre las diversas opciones para la imputación de responsabilidad, el cLC optó en su artículo I.3 por la posibilidad de dirigir las reclamaciones a la persona o las personas inscritas como propietarias del buque o, si el buque no ha sido matriculado, la persona o las personas propietarias de este.

Adicionalmente, según el artículo III.1 del cLc, el propietario del buque responsable es aquel que lo sea en el momento que se produzca el suceso causante de la contaminación. Si resultara que el suceso es producto de varios acaecimientos, será responsable quien sea propietario al tiempo de producirse el primer evento, siendo solidariamente responsables todos los propietarios cuando no pueda determinarse un orden de sucesos determinado (CLC, art. IV).

La razón de ser de esta disposición consiste en evitarle al perjudicado el problema de identificar el naviero que ha causado el daño, ${ }^{6}$ ya que en muchos países no se dota de publicidad registral imperativa a los navieros, circunstancia que dificulta su individualización. Además, si se tuviera por responsable al naviero, que generalmente no es el mismo propietario del buque, tendría que lidiar con la probable insolvencia económica de aquel para hacer frente a una responsabilidad de tan grandes magnitudes como la derivada de la contaminación marina por hidrocarburos.

Cabe destacar que el propietario del buque puede limitar su responsabilidad financiera hasta una cuantía determinada de conformidad con el arqueo ${ }^{7}$ del buque, cuantía que es garantizada por su asegurador, pues está obligado a mantener un seguro que cubra su responsabilidad en virtud del convenio,

\footnotetext{
${ }^{5}$ Esto responde a lo que la doctrina denomina 'principio de canalización' o de 'restricción de la legitimación pasiva', ampliamente difundido en el régimen de responsabilidad por daños catastróficos, que impone una determinación del sujeto responsable de carácter selectivo o excluyente.

6 "El naviero es un empresario marítimo que se dedica a la actividad de navegación marítima, y que para el ejercicio de la misma, puede requerir los servicios de un buque ya armado y equipado, o explotar el buque a casco desnudo, pero que en cualquiera de las opciones que elija, su condición de naviero no le vincula con ninguna titularidad real o dominical sobre el buque. Por tanto quien en todo momento sigue ostentando la propiedad sobre la nave es el propietario del buque" (Rodríguez, 2003).
}

${ }^{7} \mathrm{El}$ arqueo es el modo de medir el tamaño de los buques, a partir de su volumetría. 
aunque esta obligación no es aplicable a los buques que transportan menos de 2.000 toneladas de hidrocarburos como carga.

4.1.1.2. El contenido del CLC no alude a la culpa, lo que ha llevado a que se entienda que se trata de un régimen de responsabilidad de tipo objetivo, en el que no se hace una valoración de la conducta del propietario para poner en cabeza suya la responsabilidad por el daño causado, sino que basta su causación y la verificación de que provino de su actividad para endilgar la responsabilidad en comento.

Esto conlleva que el propietario del buque quede exento de responsabilidad únicamente en circunstancias muy especiales, como cuando los daños se deben a un desastre natural grave, o hayan sido causados totalmente y de modo intencional por un tercero, o se deban totalmente a la negligencia de las autoridades públicas en el mantenimiento de luces u otras ayudas a la navegación (CLC, art. III).

Tal como lo señaló la Corte Suprema de Justicia a este respecto (sentencia del 16 de mayo de 2011), la responsabilidad civil por los daños causados por derrame de hidrocarburos en el CLC es sin culpa, pues para su surgimiento basta la verificación del daño y del nexo de causalidad de aquel con la conducta del agente. Así las cosas, al tratarse de una responsabilidad objetiva, los elementos que la estructuran son el daño y la relación de causalidad, los cuales deben ser probados por la víctima que reclama la reparación de su perjuicio, en virtud de la carga de la prueba que le corresponde.

4.1.2. El FUND brinda un segundo nivel de indemnización (second tier), basado en un fondo que es financiado por los receptores de hidrocarburos, tras su transporte marítimo en los Estados que son parte en el convenio. En virtud de esta convención, los reclamantes pueden solicitar ante el Fondo una indemnización adicional cuando no hayan obtenido una indemnización plena bajo el régimen del CLC, sea porque el propietario del buque o su asegurador no son responsables según el convenio, o porque resulten ser insolventes, o cuando la suma límite de responsabilidad pagadera por ellos sea insuficiente para atender en su totalidad los daños causados.

En otras palabras, este Fondo tiene como propósito la indemnización del daño de manera subsidiaria o complementaria al CLC, cuando la reparación derivada de su aplicación haya sido insuficiente. 
4.1.3. Adicionalmente, y debido a la insuficiencia en la indemnización de este tipo de daños que se evidenció en algunos derrames de gran magnitud, como los de los buques Nadhodka (1997), Erika (1999) y Prestige (2002), en el año 2003 se adoptó un Protocolo Relativo al Convenio del Fondo de 1992, constituyéndose un Fondo Complementario a este en marzo de 2005 (Supplementary Fund Protocol, en adelante Supplementary Fund), que brinda un tercer nivel (third tier) de indemnización de los daños debidos a la contaminación en los Estados que son miembros del Fondo de 1992.

Así las cosas, cualquier persona, empresa, administración local y/o Estado miembro del Fondo de 1992 que padezca daños debidos a la contaminación por hidrocarburos transportados por un petrolero puede reclamar indemnización al propietario del buque/asegurador, como lo establece el cLC; al Fondo de 1992, como lo dispone el Fund; y, si procede, al Supplementary Fund.

Debe destacarse que los fondos internacionales de indemnización de daños debidos a la contaminación por hidrocarburos, constituidos por el Fondo de 1992, el Fondo Complementario y el Fondo de 1971, y denominados Fidac, son organismos intergubernamentales que poseen una organización común, que son regidos por un mismo director responsable de su funcionamiento y que tienen la finalidad común de indemnizar a las víctimas de los derrames de hidrocarburos persistentes procedentes de petroleros. Así, son los Fidac los receptores de las reclamaciones que se efectúan ante cualquiera de estos tres fondos y, como tal, los encargados de determinar el daño resarcible en virtud de esta regulación.

Debe resaltarse que, en caso de que el reclamante no esté de acuerdo con la indemnización fijada por los Fidac, tiene la posibilidad de acudir al tribunal judicial competente del Estado miembro donde ocurrió el daño para exigir una mayor indemnización.

Conforme a lo visto, conviene ahora examinar la cobertura de los daños que ofrece el clc y el alcance dado a este por parte de los Fidac, a fin de determinar si esta regulación es incluyente o no de la totalidad de los daños que pueden surgir de este tipo de eventos, y así poder analizar su suficiencia en cuanto a la reparación de los daños causados. 


\subsection{Daños resarcibles}

El concepto de daño por contaminación (pollution damage) es la piedra angular del sistema compuesto por el cLC y el Fund. En ese sentido, los daños resarcibles en este sistema consisten en:

a) pérdidas o daños causados fuera del buque por la impurificación resultante de las fugas o descargas de hidrocarburos procedentes de ese buque, dondequiera que se produzcan tales fugas o descargas, si bien la indemnización por deterioro del medio, aparte de la pérdida de beneficios resultante de dicho deterioro, estará limitada al costo de las medidas razonables de restauración efectivamente tomadas o que vayan a tomarse; b) el costo de las medidas preventivas y las pérdidas o los daños ulteriormente ocasionados por tales medidas (cLC, art. I.6).

Este concepto, que al parecer adopta un enfoque amplio en razón de su redacción, realmente resulta limitado cuando se examinan con detalle las restricciones que imponen los Fidac respecto del objeto del resarcimiento (Ruda, 2008, pp. 113-119).

Específicamente, las limitaciones al resarcimiento del daño patrimonial devienen del ámbito espacial al que determina la norma, de la calidad de la materia causante del daño, de la cuantía resarcible del daño y de la concepción clásica de patrimonio adoptada por los Fidac, en la que se excluyen elementos inmateriales no susceptibles de valoración económica y por virtud de la cual se repara el daño ambiental consecutivo, principalmente, y no el daño ambiental puro ni los daños morales.

En este sentido, se destaca que, al reparar solo los daños por contaminación no se resarcen los daños generados de una manera distinta, lo cual desconoce otras posibilidades de dañar el medio ambiente diferente a esta, como, por ejemplo, el uso excesivo de los recursos naturales.

Adicionalmente, debe tenerse en cuenta que el sistema cubre solo la contaminación causada por un barco que transporta hidrocarburos persistentes como carga, dejando sin que se cubran los daños producidos de la contaminación por fugas o descargas de otro tipo de hidrocarburos, como el combustible, que son de tipo ligero pero que igualmente generan contaminación en el medio ambiente. Lo que sucede en estos casos es que, al tratarse de hidrocarburos ligeros, generalmente se evaporan y contaminan el aire, principalmente. No 
obstante, es un error excluirlos, pues se trata de elementos contaminantes que volverán al mar en virtud del ciclo del agua que le compone.

A lo anterior se añade que no toda contaminación es relevante para el convenio, sino solo aquella que causa un daño en el territorio, mar territorial o zona económica exclusiva (ZEE) — o zona equivalente- de cualquier Estado parte de la convención (CLC, art. II). Esta restricción geográfica excluye los daños que puedan causarse al medio marino en alta mar, circunstancia que desconoce el carácter unificado del ecosistema y las posteriores consecuencias negativas que ello puede tener en los mares de cada Estado parte.

Observemos entonces la cobertura dispuesta en virtud de la regulación sub examine.

\subsubsection{Daños patrimoniales}

Aunque de manera directa el daño se produce en el medio ambiente, el resultado o consecuencia del evento dañoso puede verse reflejado en el patrimonio de cualquier individuo. Este daño patrimonial puede consistir en un daño emergente o en un lucro cesante, según la tradicional clasificación doctrinaria, que corresponden a la pérdida patrimonial efectiva o a la ganancia dejada de percibir como consecuencia del daño, respectivamente.

\subsubsection{Daño emergente}

Cuando el medio ambiente resulta lesionado, el daño emergente puede consistir en el coste de la reparación del medio ambiente, el coste de evaluar el daño, la pérdida de uso de los recursos naturales y/o en el coste de las medidas preventivas.

No obstante, el clc declara resarcible el daño al medio ambiente, pero limitado al coste de las medidas razonables de restauración efectivamente llevadas a cabo o que se lleven a cabo, así como los costes de medidas de prevención o reducción del daño y la pérdida o daño producido por tales medidas, y el lucro cesante (CLC, arts. I y II).

Así, los Fidac indemnizan los costes razonables de limpieza, reparación o reposición de bienes que hayan sido contaminados por hidrocarburos (Fondo Internacional de Daños debidos a Contaminación por Hidrocarburos, 2013).

Dentro de los costes de limpieza, se comprenden los costes de limpiar, tanto bienes privados como públicos, por ejemplo, la orilla del mar y la ribera de los 
ríos y las playas, así como las instalaciones de las playas, barcos y construcciones relacionadas con el mar, verbi gratia, los cascos de los buques -incluidas las embarcaciones de recreo, los aparejos de pesca y las instalaciones de maricultura- $\mathrm{y}$, por supuesto, la limpieza del denominado chapapote. ${ }^{8}$ Así mismo, se cubren los costes de limpieza de las tomas, maquinaria y equipo de instalaciones industriales que extraen agua del mar, como las centrales eléctricas y las desalinizadoras.

En adición, los Fidac han reconocido el coste del salario del personal especialmente empleado para las operaciones de limpieza, así como los costes del material y equipamiento requeridos para la operación. El coste de limpiar, reparar y reponer el material y el equipamiento está igualmente incluido.

También, se aceptan las reclamaciones por costes de reparación de carreteras, muelles y diques dañados por vehículos pesados, como camiones y equipo de remoción de tierras, utilizados en la operación de limpieza. Sin embargo, se tienen en cuenta el estado de dichos bienes antes del incidente para hacer el correspondiente descuento.

En caso de no ser posible limpiar o reparar estos bienes, los Fidac pagan el coste de reposición del bien, previo descuento del desgaste, es decir, no se indemniza el coste total de reponer el bien antiguo por el nuevo, sino que se tiene en cuenta la antigüedad del bien y su duración prevista.

Es de recordar que, al estar fuera de cobertura los daños causados fuera del barco, no quedan cubiertos los costes de limpieza o restauración del propio buque, ni de la carga que transportaba, si esta resultara afectada por el derrame (Ruda, 2007, pp. 69-84).

Como medidas de restauración contempladas, se incluye también el coste de construcción de las barreras de contención del petróleo que se utilizan para evitar que el hidrocarburo alcance la costa, así como el coste de los dispersantes usados con el fin de combatir el derrame.

Por lo general, la reparación del medio ambiente dañado va acompañada de la realización de estudios que permitan determinar la naturaleza y magnitud de los daños causados al medio ambiente por el derrame y establecer si son necesarias y factibles las medidas de restauración.

En ocasiones, estos estudios pueden ser costosos por su complejidad, razón por la que los Fidac han fijado su contribución con los costes de los estudios

\footnotetext{
${ }^{8}$ Se conoce como 'chapapote' el petróleo o aceite mineral ilegalmente soltado por los barcos hacia la costa, en ocasiones procedente de sus tanques de combustible o maquinaria.
} 
posteriores al derrame, siempre y cuando estos se refieran a daños comprendidos dentro de la definición de daños por contaminación establecida en el convenio.

No obstante, los Fidac se han negado a compensar el coste de estudios de naturaleza puramente científica, circunstancia que puede dificultar la determinación de las consecuencias reales del daño ambiental causado.

Respecto del coste de las medidas preventivas, el clc cubre dicho rubro con independencia del lugar donde se adopten. Así, a diferencia de lo que ocurre con la responsabilidad civil tradicional, estas medidas son cubiertas por los Fidac incluso si el vertido finalmente no sucede, si ha existido una amenaza grave e inminente del daño, es decir, a pesar de la no existencia del daño pero en circunstancias que hacían prever su ocurrencia con cierta probabilidad.

Igualmente, se consideran medidas preventivas resarcibles aquellos costes de monitorización de las operaciones de limpieza del vertido que ya se ha producido. Los Fidac las describen como medidas de prevención prudentes y razonables, pues se encargan de detectar los efectos del vertido.

Debe destacarse también que el clc exige que las medidas preventivas hayan sido razonables, es decir que hayan sido necesarias y conducentes a la prevención del daño. Ello puede implicar alguna dificultad probatoria para el reclamante, pues de lo que se trata este requisito es del deber que tiene la víctima de demostrar el nexo causal entre el daño y las medidas tomadas, las cuales deben ser efectivas para prevenir aquel.

Este criterio de razonabilidad es la manera en que los Fidac impiden que haya un aprovechamiento indebido del incidente para indemnizar medidas que carecen de conexión con el daño. Esta razonabilidad es juzgada mediante la implementación de criterios objetivos a través de los cuales se pretende verificar su cumplimiento en cada caso concreto. Los criterios usados versan sobre la información que disponía el encargado de adoptar la medida preventiva; la capacidad del medio ambiente para repararse por si solo, pues en algunos casos no se justifica tomar medidas preventivas dado el bajo impacto del daño en el medio; y el valor económico de la prevención adoptada. Este último criterio puede ser bastante discutible, ya que con base en él podría impedirse una reparación integral del daño, por considerar muy elevado el coste de una reparación que es esperable que sea cuantiosa, dada la naturaleza de los bienes que se protegen.

Finalmente, las campañas de marketing efectuadas con la finalidad de disminuir el impacto generado en la población acerca de consumir determinado 
producto originario de esa región, o vacacionar en este lugar, también constituyen medidas preventivas y otorgan derecho a reclamar su coste.

\subsubsection{Lucro cesante}

El lucro cesante es un daño indemnizable a condición de que se trate de una pérdida que sufre la víctima como consecuencia de la contaminación. Los ejemplos típicos de beneficiados por estos daños son los pescadores, los hoteles, los restaurantes, que disminuyen sus ventas debido a la baja de turistas, entre otros.

En adición, hay lugar a indemnizar las pérdidas de las personas cuyos bienes no han quedado contaminados, pero que no pudieron continuar con su actividad económica por causa de la contaminación. Así sucedería en el caso de los pescadores cuyos aparejos no se contaminaron, pero que deciden no pescar para evitar que se contaminen sus aparejos y la pesca, con la consiguiente pérdida económica.

Quienes sufren pérdidas económicas no resultantes de daños materiales, por ejemplo, negocios que dependen de las actividades de pesca o maricultura, se les reconoce indemnización, pero solo si dichas pérdidas se deben a la contaminación.

Un factor importante que se tiene en cuenta a la hora de valorar el daño es la proximidad geográfica entre la actividad comercial del reclamante y la zona contaminada; así mismo, se valora el grado en que la actividad del reclamante depende de los recursos afectados, la posibilidad de que el reclamante disponga de otras fuentes de abastecimiento u oportunidades comerciales, y en qué grado la actividad comercial del reclamante forma parte integral de la economía de la zona afectada por el derrame.

Los Fidac también han considerado que algunos daños materiales pueden producir pérdidas económicas mientras no se procede a la limpieza, reparación o reposición de los bienes, toda vez que el afectado no puede llevar a cabo su actividad comercial de la manera acostumbrada, por lo que se indemnizan tales pérdidas consecuentes.

\subsection{Daños no resarcidos}

\subsubsection{Daños morales}

Los daños morales quedan fuera del ámbito de aplicación del CLC, pues, al centrarse en los daños por contaminación y excluir los daños por muerte, atropello, 
impacto, fuego o explosión, se deja sin posibilidades la cobertura del daño inmaterial que se produzca en esos eventos.

Por supuesto, la falta de cobertura de estos daños no implica su no acaecimiento. Por el contrario, aun en los eventos de contaminación, es posible dilucidar la ocurrencia de daños a la vida y a la salud, ${ }^{9}$ que también provocan perjuicios morales por causa de los sentimientos de angustia que se generan en las personas a raíz del suceso. Además, es posible que de la contaminación se produzca directamente un daño moral en las personas, como ocurriría, verbi gratia, con los residentes del lugar, los niños, los voluntarios, o en la población nativa o indígena que tenga sentimientos de valoración a la naturaleza, o, incluso, en un mero televidente, que, tras observar la catástrofe causada, siente una angustia por encima de la normal que un suceso cotidiano le produciría.

No habiendo reconocimiento en este sentido, se entiende que el CLC excluye la indemnización de otros tipos de daños inmateriales.

\subsubsection{Daño ambiental puro}

Como se ha evidenciado del estudio realizado, el sistema de responsabilidad civil internacional por derrame de hidrocarburos persistentes en el mar indemniza, principalmente, el daño ambiental consecutivo, es decir, aquel que por reflejo lesiona los derechos y bienes individuales de una persona por causa de la afectación al medio ambiente, el cual no se repara como bien en sí mismo considerado.

Así, aunque se resarce el costo de implementar algunas medidas tendientes a la reparación del daño ambiental puro, como sería el coste de la limpieza de las costas, las orillas de los mares, el chapapote o de las especies afectadas, dicha indemnización se efectúa desde una perspectiva monetaria que premia la reposición del patrimonio dispuesto para ello, mas no la afectación del ambiente en sí mismo, que es beneficiado por la medida.

Entonces, pese a que se indemnizan los costos de limpieza del entorno afectado, la reparación de la totalidad del daño ambiental puro queda en ciernes, pues los Fidac no admiten otro tipo de respuestas jurídicas diferentes a esta, que pueda dejar indemne la totalidad del daño ecológico puro causado. Por ejemplo, ninguna medida se adopta para compensar la pérdida de individuos de una especie animal, o la totalidad de la especie, o la afectación que se

\footnotetext{
${ }^{9}$ Por ejemplo, muerte de voluntario por resbalón en piedra petroleada.
} 
le pueda causar en su supervivencia, pues ni siquiera se compensan los costes del personal que trabaja por revertir tales pérdidas.

Esta situación obedece a varias circunstancias. Por una parte, el ClC no premia la reparación in natura del daño como obligación principal después de haberse causado, sino que, por su propia naturaleza, pretende la indemnización de ciertos daños a través de fondos de dinero, priorizando la obligación de compensar lo perdido de manera monetaria.

En este contexto, los Fidac han considerado que el daño ambiental puro se trata de un daño de difícil valoración y que, por lo tanto, no puede ser resarcido (Ruda, 2007, pp. 102-103). Estiman que la valoración de tal tipo de daños presenta dificultades, debido a que esta clase de cosas no tiene un valor equivalente en el mercado. Así, por ejemplo, al no saber cuánto cuesta la reparación de un individuo de una especie animal, no procede a su reparación.

En este orden de ideas, los Fidac tampoco acceden a las indemnizaciones reclamadas de daños al medio ambiente que se basan en una cuantificación abstracta o calculada conforme a modelos teóricos.

\section{Conclusiones}

Visto grosso modo el cubrimiento de los daños que se efectúa por virtud del CLC adoptado en Colombia, aparece clara la insuficiencia de esta regulación para lograr una reparación integral de los daños que pueden generarse por el derramamiento de hidrocarburos persistentes en el mar. Así, no obstante el sistema internacional acogido busca el resarcimiento de daños por estos eventos, tal resarcimiento es apenas parcial y, por lo tanto, insuficiente.

En este sentido, se evidencia que la responsabilidad civil en estos eventos sigue teniendo una tendencia antropocéntrica-clásica que impide que se abra la posibilidad a reparaciones novedosas que trasciendan el pago de sumas de dinero y reparen, en la mayor medida de lo posible, el medio ambiente afectado.

En ese contexto, es menester implementar un concepto de patrimonio más amplio del que se maneja actualmente, para que se comprendan también intereses y bienes inmateriales y colectivos que pueden ser afectados y que requieren igualmente reparación (Henao, 2000).

Así mismo, es bastante cuestionable que se deje sin reparación el daño ecológico puro por ser un daño de difícil cuantificación, comoquiera que la dificultad de su determinación no puede conllevar que se ignore su acaecimiento y, por lo tanto, su reparación. En ese sentido, debería admitirse la estimación 
en equidad del daño, o haber lugar a una reparación in natura que se financie con los dineros del Fondo, con la que se pretenda, en la mayor medida posible, volver las cosas a su estado anterior.

Con todo, aun cuando en este sistema no se lograse la reparación de la totalidad de los daños, en el restante derecho colombiano es posible encontrar soluciones jurídicas para su reparación en el ámbito civil.

En este sentido, los jueces colombianos no pueden seguir siendo apáticos al reconocimiento de daños ambientales puros e inmateriales que se produzcan como consecuencia de este tipo de derrames.

Así, además de las posibilidades de la jurisdicción al momento de decidir las acciones populares y de tutela que se impetren contra el causante de estos daños, el juez civil debe ser consciente de que hay eventos en los que la lesión de intereses o derechos colectivos converge con la afectación de derechos individuales, como sucedería cuando se daña un ecosistema en específico que es propiedad de un particular.

En tales eventos, debería reflexionarse acerca de las medidas cautelares y sobre la naturaleza de la reparación decretada dentro de los procesos de responsabilidad civily de las acciones de grupo, en tanto en esos escenarios debería también ser posible obtener la atención cautelar y la reparación del medio ambiente, in natura, de manera prioritaria o convergente con los derechos individuales afectados.

Esta extensión de las posibilidades de reparación por tales eventos se enmarcaría dentro de lo dispuesto en nuestra Constitución Nacional, de gran talante ecológico, y en el artículo 16 de la Ley 23 de 1973, que responsabiliza a los particulares por el daño a los recursos naturales de propiedad privada.

No obstante estas posibilidades jurídicas que deben estudiarse, la apatía de los ciudadanos frente a la presentación de demandas que defiendan el medio ambiente en eventos de daños por derrame de hidrocarburos al mar sigue siendo evidente, además de ser alimentada por circunstancias de violencia provenientes de los interesados en evadir condenas civiles o responsabilidades de otro tipo por estos daños.

En este contexto, aún es largo el camino que debemos trasegar para llegar a la reparación integral de los daños causados por derramamiento de hidrocarburos en el mar dentro del ámbito civil. No obstante, las bases están dispuestas para dar impulso al desarrollo de la temática y la solución de la casuística. 


\section{Bibliografía}

Carvajal, M. (2005). Regulación colombiana del medio ambiente en cuanto siniestros marítimos. Universitas Estudiantes, 2.

Casas, S. (2002). Responsabilidad por daños al medio ambiente. Lecturas sobre derecho del medio ambiente 3. Bogotá: Universidad Externado de Colombia.

Colombia, Corte Suprema de Justicia, Sala de Casación Civil y Agraria. Sentencia del 27 de marzo de 1998. M. P.: Carlos Esteban Jaramillo.

Colombia, Corte Suprema de Justicia, Sala de Casación Civil. Sentencia del 16 de mayo de 2011. M. P.: William Namén Vargas.

Fondo Internacional de Daños debidos a Contaminación por Hidrocarburos. (2013). Manual de reclamaciones.

Henao, J. C. (2000). Responsabilidad del Estado colombiano por daño ambiental. En Responsabilidad por daños al medio ambiente. Bogotá: Universidad Externado de Colombia.

Henao, J. C. (2007). El daño. Análisis comparativo de la responsabilidad extracontractual del Estado en derecho colombiano y francés. Bogotá: Universidad Externado de Colombia.

Henao, J. C. (2009). De la importancia de concebir la amenaza y el riesgo sobre derechos ambientales como daño cierto. En AA. vv. Daño ambiental, T. II. Bogotá: Universidad Externado de Colombia.

Hinestrosa, F. (1998). Prólogo. En El daño. Análisis comparativo de la responsabilidad extracontractual del Estado en derecho colombiano y francés. Bogotá: Universidad Externado de Colombia.

Koteich, M. (1993). Responsabilidad contractual y aquiliana. Revisión de una distinción tradicional con base en la culpa y su graduación. En Homenaje a Fernando Hinestrosa: 30 años rector. Universidad Externado de Colombia.

Rodríguez,M.(2003). La obligación de indemnizar del propietario del buque-tanque. Barcelona: Tirant lo Blanch.

Ruda, A. (2007). La tipología de los daños causados por el Prestige. En La responsabilidad por los daños causados por el hundimiento del Prestige. Iustel.

Ruda, A. (2008). El daño ecológico puro. La responsabilidad civil por el deterioro del medio ambiente, con especial atención a la Ley 26/2007, de 23 de octubre, de responsabilidad medioambiental. Pamplona: Thomson Arazandi.

Vallejo, F. (1985). La contaminación del mar por hidrocarburos: régimen legal sobre prevención, responsabilidad civil y seguros. Revista del Colegio Mayor de Nuestra Señora del Rosario, 529(78) Bogotá: Universidad del Rosario. 


\title{
5. La facultad a prevención
}

\author{
Andrés Gómez Rey* \\ Gloria Amparo Rodríguez** \\ Iván Vargas Chaves***
}

\section{Introducción}

\begin{abstract}
A partir de la expedición de la Ley 1333 de 2009, fue establecido en Colombia el régimen sancionatorio administrativo ambiental, ${ }^{1}$ el cual ha generado amplios debates por su particular estructura y contenido. Entre lo más llamativo encontramos: a) comprende un régimen de responsabilidad personal;
\end{abstract}

\footnotetext{
* Abogado de la Universidad de La Sabana; especialista en Derecho Ambiental de la Universidad del Rosario; magíster en Derecho Administrativo de la Universidad del Rosario. Profesor de cátedra de pregrado y posgrado de diversas instituciones, entre ellas la Universidad del Rosario, la Universidad Icesi y la Universidad de La Salle; ha sido asesor de entidades como el Ministerio de Ambiente y Desarrollo Sostenible, la Defensoría del Pueblo, la Superintendencia de Servicios Públicos Domiciliarios y algunas Corporaciones Autónomas Regionales. De igual manera, acompaña a empresas privadas en temas ambientales, especialmente en procedimientos sancionatorios. Cuenta con diversas publicaciones sobre derecho ambiental y servicios públicos domiciliarios. Correo electrónico: agomezrey@icloud.com

** Abogada; especialista en Derecho Ambiental, Negociación, Conciliación y Arbitraje, y Derecho Médico y Sanitario de la Universidad del Rosario; magíster en Medio Ambiente y Desarrollo con énfasis en Gestión Ambiental de la Universidad Nacional de Colombia; y doctora en Sociología Jurídica e Instituciones Políticas de la Universidad Externado de Colombia. Actualmente, se desempeña como profesora principal de carrera de la Facultad de Jurisprudencia de la Universidad del Rosario, donde además es directora de la Especialización y de la Línea de Investigación en Derecho Ambiental. Cuenta con diferentes publicaciones sobre temas ambientales y étnicos, y ha sido editora académica de otras obras. Correo electrónico: gloria.rodriguez@urosario.edu.co

** Abogado de la Universidad del Rosario; magíster en Derecho de la Universidad de Génova (Italia). Actualmente, es investigador en formación doctoral en la Universidad de Barcelona y profesor adscrito de Derecho Ambiental en la Universidad Nacional Autónoma de México. Correo electrónico: ivargas@outlook.com

${ }^{1}$ Sin olvidar lógicamente sus antecedentes, como el artículo 339 del Decreto-Ley 2811 de 1974, el Decreto 1594 de 1984 (se debe precisar que todos los decretos reglamentarios hoy han sido recogidos por la norma única del sector ambiente: Decreto 1076 de 2015), el artículo 85 de la Ley 99 de 1993, modificados y derogados por la Ley 1333 de 2009.
} 
b) establece dos formas de convertirse en infractor, en palabras de Rodríguez, Gómez y Monroy (2012, p. 237): por violación de las normas² de contenido ambiental o por configurarse los elementos de la responsabilidad civil extracontractual, determinados en el artículo 2341 del Código Civil; ${ }^{3}$ c) se trata de un compendio normativo que refleja un régimen de responsabilidad subjetiva por cuanto contempla como elementos: el hecho, la culpa o el dolo, el nexo causal y el daño. Lo cual llama la atención puesto que los ordenamientos jurídicos de otros países van encaminados a la configuración de la responsabilidad objetiva en los temas ambientales; d) aunque la responsabilidad y el procedimiento como es natural debe ser permeado por los principios constitucionales y legales, ${ }^{4}$ como el debido proceso (presunción de inocencia y otros), trae consigo la presunción de la culpa o el dolo y la inversión de la carga de la prueba, lo cual además fue avalado por nuestra Corte Constitucional (Sents. C-595/10, C-1007/10 y C-742/10); e) posee en la doctrina críticas que llevan a pensar que, tanto por la forma en la cual fue estructurada la ley como por el comportamiento de sus operadores jurídicos, se tratará de un régimen que comprende un sistema que presume todos los elementos de la responsabilidad (Rodríguez, Gómez y Monroy, 2012, p. 246). ${ }^{5}$

\footnotetext{
${ }^{2}$ Entiéndase por normas aquellas emanadas del poder legislativo, así como actos administrativos.

${ }^{3} \mathrm{Si}$ bien es cierto que se entiende como 'agente' o sujeto pasivo de la acción sancionatoria ambiental configurar los elementos de la responsabilidad civil extracontractual, esto no implica de ninguna manera una remisión a las reglas y demás contenido de esta forma o tipo de responsabilidad. Así pues, la solidaridad y otras figuras no contemplan expresa remisión.

${ }^{4}$ En especial, los contenidos en a) los artículos 29,209 y otros de nuestra Constitución Política; b) los comprendidos en el artículo 1º de la Ley 99 de 1993; c) aquellos del artículo 3o de la Ley 1437 de 2011 o Código de Procedimiento Administrativo y de lo Contencioso Administrativo; y d) los generales de la actuación y función administrativa y del derecho punitivo. Tales como la prohibición de la analogía, el non bis in idem, la doble instancia, la no retroactividad de la ley, el debido proceso (presunción de inocencia, principio de legalidad, nulla poena sine lege, derecho de contradicción, no dilación injustificada en los trámites administrativos) y la buena fe.

${ }^{5}$ Para mayor comprensión, ya que se trata de un tema sumamente teórico, se recomienda consultar la fuente citada. En este sentido, no pretenden los autores detenerse en la presente idea, sino simplemente mostrar parte de lo que existe en la doctrina como novedades del régimen sancionatorio ambiental colombiano. Sin embargo, diremos: a) para explicarlo en términos simples: la autoridad ambiental, al conocer la presunta infracción, señala a una persona que considere relacionada con esta — sin mayor sustento probatorio- Con ello, tiene la autoridad vinculado al procedimiento: el daño (producto de la infracción), el sujeto que ella eligió y nexo causal. Quedando faltando la culpa y el dolo, que la ley los presume. Por tal razón, todos los elementos quedan presuntos. b) Para explicarlo desde el punto de vista teórico: la autoridad ambiental conoce el daño y señala a una persona que considera relacionada con la
} 
La Ley 1333 de 2009, además de las anteriores particularidades, contempla en su artículo $2^{\circ}$ la llamada facultad a prevención, figura que llama la atención por sus novedades, que estudiaremos y analizaremos en el presente texto. El artículo $2^{\circ}$ de la mencionada norma establece:

\begin{abstract}
Artículo $2^{\circ}$. Facultad a prevención. El Ministerio de Ambiente, Vivienda y Desarrollo Territorial; la Unidad Administrativa Especial del Sistema de Parques Nacionales Naturales; las Corporaciones Autónomas Regionales y las de Desarrollo Sostenible; las unidades ambientales urbanas de los grandes centros urbanos a que se refiere el artículo 66 de la Ley 99 de 1993; los establecimientos públicos a los que hace alusión el artículo 13 de la Ley 768 de 2002; la Armada Nacional; así como los departamentos, municipios y distritos, quedan investidos a prevención de la respectiva autoridad en materia sancionatoria ambiental. En consecuencia, estas autoridades están habilitadas para imponer y ejecutar las medidas preventivas y sancionatorias consagradas en esta ley y que sean aplicables, según el caso, sin perjuicio de las competencias legales de otras autoridades. Parágrafo. En todo caso las sanciones solamente podrán ser impuestas por la autoridad ambiental competente para otorgar la respectiva licencia ambiental, permiso, concesión y demás autorizaciones ambientales e instrumentos de manejo y control ambiental, previo agotamiento del procedimiento sancionatorio. Para el efecto anterior, la autoridad que haya impuesto la medida preventiva deberá dar traslado de las actuaciones a la autoridad ambiental competente, dentro de los cinco (5) días hábiles siguientes a la imposición de la misma.
\end{abstract}

infracción, presume entonces el sujeto, el nexo y el daño. Como la culpa y el dolo, la ley los presume, todos los elementos son presuntos (es una responsabilidad que presume todos sus elementos). En términos jurídico-teóricos: cuando la culpa es presunta, el hecho real causante del daño es desconocido (es decir, la culpa desconocida se considera la causante del daño); por tal razón, el nexo causal corre la misma suerte so pena de ser inoperante. Pero lo anterior genera un peligro para los involucrados, ya que el presunto responsable puede llegar a ser cualquiera, así se encuentre alejado de la cadena de responsabilidad. "En otras palabras, como en la realidad se conoce una violación o una afectación que prende las alarmas de la autoridad ambiental, se vincula a cualquier sujeto del cual se presume su culpa y por ende el nexo causal entre los primeros y se configuran de manera presunta todos los elementos de la responsabilidad" (Rodríguez, Gómez y Monroy, 2012, p. 248). 
Aunque de su mera lectura no pareciera tener mayores inconvenientes, desde la óptica del derecho administrativo sí, ya que fue diseñada para quebrantar parte de la antigua teoría general del acto administrativo. Entonces, encontramos que vía ley ha comenzado el derecho ambiental a construir una estructura por fuera del derecho administrativo. Siendo entonces interesante detenernos en dicha institución a través del presente escrito.

Para lograr analizar y estudiar la facultad a prevención, hemos planteado como estructura del documento: primero (cuestiones generales), un aparte sobre los elementos de juicio necesarios para el estudio de la 'facultad a prevención' desde el punto de vista del derecho administrativo, donde se hará referencia al concepto de acto administrativo; los elementos de existencia, en especial, los atinentes al órgano y competencia; y las consecuencias de la inobservancia de los citados elementos, para mostrar cómo está construido el derecho administrativo de manera general. Segundo (cuestiones específicas), un aparte sobre el análisis de la figura 'facultad a prevención', con el fin de mostrar las razones por las cuales su creación fue más allá de las posibilidades y reglas de dicho público; para así terminar con la recopilación in genere de lo observado.

El aspecto metodológico recaerá de manera principal en el análisis dogmático del derecho (sistemas descriptivos), a través del cual se realizará una recopilación bibliográfica especializada sobre la materia, incluyendo, lógicamente, la consulta de las fuentes del derecho: ley, jurisprudencia y doctrina.

\subsection{Parte general. Conceptos del derecho administrativo necesarios para el análisis de la facultad a prevención}

A continuación, estudiaremos brevemente las generalidades del acto administrativo y de la teoría general del acto administrativo necesarias para entender lo particular y especial de la figura llamara facultad a prevención. A manera de introito, traeremos algunas de las definiciones de acto administrativo, para contextualizar el objeto al cual nos referiremos:

$\mathrm{El}$ acto administrativo ${ }^{6}$ es entendido como fundamento e institución principal del derecho administrativo por ser el instrumento básico de manifestación y ejercicio de la actividad de la administración, así como de comu-

\footnotetext{
${ }^{6}$ Siguiendo en esta definición la tesis de maestría de uno de los autores: Gómez Rey (2012b).
} 
nicación con las personas en la nación.Vidal Perdomo (1994, p. 132) propone que es el producto jurídico de la función administrativa; Santofimio (1998, p. 125) afirma que el acto administrativo ha adquirido en los sistemas jurídicos modernos, especialmente en aquellos ceñidos por los principios del Estado de derecho, connotaciones de columna vertebral del derecho administrativo. Lo anterior no solo desde el punto de vista del ejercicio de la función administrativa, sino también del régimen de garantías que se desprende de su existencia.

El Consejo de Estado (sentencia del 30 de abril de 1998) entiende por acto administrativo "la expresión de voluntad de una autoridad o de un particular en ejercicio de funciones administrativas, que modifique el ordenamiento jurídico, es decir, que por sí misma cree, extinga o modifique una situación jurídica”, destacando como componentes de su esencia la voluntad, el organismo que lo expide y los efectos jurídicos llamados a producir (sentencia del 9 de noviembre de 1998). Por último, diremos que Penagos (2008, p. 20) lo define como una "decisión unilateral de naturaleza administrativa, de cualquier órgano del Estado, o de los particulares autorizados por la ley, con la finalidad de crear, modificar o extinguir una relación jurídica”.

Siguiendo a Berrocal (2001, p. 121), el acto administrativo es toda declaración o decisión unilateral que en ejercicio de la función administrativa esté llamada a producir efectos jurídicos.

Con lo dicho, nótese que esas características de las decisiones estatales comprenden una serie de elementos para su existencia, validez y eficacia, los cuales, en caso de ser incumplidos, tendrán un 'castigo', o padecerán de 'vicios'o 'patologías'. Por tal razón, a continuación, veremos aquellos de especial importancia para el estudio de la facultad a prevención contenida en la Ley 1333 de 2009.

\subsubsection{Del órgano y la competencia}

Toda decisión que sea adoptada por parte de las entidades del Estado debe cumplir con los elementos o condiciones propuestas en la teoría general del acto administrativo (Penagos, 2008, p. 20), a saber: a) de existencia: órgano, competencia y contenido; b) de validez: voluntad, forma y procedimiento; $y$ c) de eficacia u oponibilidad: publicación, notificación o comunicación. No obstante, para efectos de estudiar la 'facultad a prevención', haremos énfasis únicamente en los de la existencia. 
El primer elemento de la existencia del acto administrativo es conocido como el órgano, órgano competente o sujeto activo, que, según Penagos (2001, p. 281), es aquel que tiene la capacidad jurídica para proferir actos administrativos, "[...] es decir, que el acto administrativo, debe emanar de un órgano con capacidad jurídica para ejercer la función administrativa, manifestada en actos administrativos [...]".

Entonces, quien tome decisiones a través de actos administrativos deberá estar facultado por el ordenamiento jurídico para hacerlo teniendo en cuenta que "ninguna autoridad del Estado podrá ejercer funciones distintas de las que le atribuyen la Constitución y la ley" (c.P., art. 121), lo cual se conoce como principio de legalidad.

Así, las posibilidades de actuación de todas las entidades del Estado (de todas sus ramas o funciones del poder público, incluidos los particulares en ejercicio de la función administrativa) poseen como límite los preceptos que la ley establece, de los cuales no deben ni pueden escapar. Piénsese entonces que, si las autoridades que componen el Sistema Nacional Ambiental, 7 encargadas de la protección, preservación y cuidado (in genere) de los recursos naturales de conformidad con lo dispuesto en la Ley 99 de 1993, emiten una decisión tendiente a cesar los efectos civiles de un contrato matrimonial, estaría pues este acto incumpliendo el elemento objeto de estudio.

El órgano o sujeto activo de la competencia, como lo explica Santofimio (1998, p. 140), es, por regla general, el depositario de la competencia necesaria para crear el acto administrativo, esto es, el órgano del Estado revestido de funciones administrativas para adoptar decisiones de manera unilateral

7 a) El Ministerio de Ambiente y Desarrollo Sostenible, antes Ministerio de Ambiente, Vivienda y Desarrollo Territorial, fue creado con la Ley 99 de 1993 como rector y encargado de formular la política ambiental colombiana. Se constituye como la cabeza visible del organigrama estatal.b) Las Corporaciones Autónomas Regionales y las de Desarrollo Sostenible, quienes son autoridad ambiental de carácter regional, llamadas a la protección y vigilancia de los recursos naturales renovables.c) Los grandes centros urbanos que, de conformidad con lo dispuesto en el artículo 66 de la Ley 99 de 1993, poseen las mismas funciones de las CAR, en el área urbana de los municipios con una población mayor o igual a un millón de habitantes. d) Los institutos de investigación y el subsistema de investigación ambiental, llamados a generar tendencias técnicas sobre la materia. Sobre estos hay que indicar que, aunque poseen funciones similares a las CAR, no se conoce permiso ambiental por ellos otorgados. Entre ellos encontramos el Instituto de Investigación de Recursos Biológicos Alexander von Humboldt, el Instituto Amazónico de Investigaciones Científicas Sinchi y el Instituto de Investigaciones Ambientales del Pacífico John von Neumann. e) Las unidades ambientales urbanas y la Unidad Administrativa Especial del Sistema de Parques Nacionales Naturales. 
tendientes a crear, modificar o extinguir en relaciones en el mundo jurídico, el cual será quien, bajo las reglas de la teoría de los actos administrativos unilaterales, contemple la competencia para actuar.

A su vez, la competencia (aquello que el ordenamiento jurídico asigna al órgano o sujeto activo), de acuerdo con Rodríguez (2001,p. 247), es la facultad o poder jurídico que tiene una autoridad para ejercer determinada función. Es expresa, ${ }^{8}$ irrenunciable ${ }^{9}$ e improrrogable, ${ }^{10}$ y debe ser ejercida directamente por quien posea la capacidad legal.

Adicionalmente, plantea Rodríguez (2001) que la competencia posee tres elementos:
[...] la competencia ratione materiae. Se refiere al elemento material de la competencia, es decir, al objeto de ella. Ese objeto se traduce en las diferentes funciones que una autoridad puede ejercer legalmente [...]. La competencia ratione loci. Es la competencia territorial, o sea, el territorio dentro del cual la autoridad puede ejercer legalmente sus funciones [...]. La competencia ratione temporis. Es la competencia temporal. Se refiere al tiempo durante el cual la autoridad puede ejercer legalmente sus funciones.

Por último, el mismo autor cuenta que "[...] se reconoce doctrinariamente que la capacidad entrándose en la teoría del acto administrativo se traduce en términos de competencia. En este sentido, será capaz la autoridad que tiene competencia para el ejercicio de un asunto [...]", fusionando pues en una sola condición la competencia y el órgano.

\subsubsection{Del incumplimiento del órgano y la competencia}

Sobre la competencia dice Rodríguez (2001, p. 247) que esta facultad es dada por la ley y es un requisito de orden público, es decir que es de estricto cumplimiento, de manera que, si no existe, el acto nace, pero viciado de ilegalidad. A

\footnotetext{
${ }^{8}$ Ya que debe estar clara y plenamente consagrada en el ordenamiento jurídico.

${ }^{9}$ Por cuanto el funcionario debe ejercer las obligaciones establecidas en los manuales de funciones o similares, sin que pueda abstraerse de ellas.

${ }^{10}$ Puesto que no depende de la voluntad de la personas, sino de la necesidad de cumplir con los fines propios del Estado.
} 
su vez, y según García (2008, p. 119), expone que, en presencia del incumplimiento de los requisitos de órgano y competencia, la decisión estatal “[...] es el acto no nacido, no venido a la vida jurídica por faltarle un elemento sustancial para ello [...]".

Encontrando con ello dos de las posiciones jurídicas predominantes sobre la materia: la inexistencia del acto administrativo y la presencia de vicios graves que generan su nulidad derivada de la inobservancia de los elementos órgano y competencia. ${ }^{11}$

La inexistencia, plantea el Consejo de Estado (sentencia del 6 de diciembre de 2012) citando a Vedel Georges:

[...] se trata de una de las cuestiones más delicadas e inciertas del contencioso-administrativo. La noción de inexistencia parece haber sido tomada del derecho civil; corresponde a la idea de que ciertos vicios son de tal forma graves que afectan no solamente a la validez del acto jurídico, sino incluso a su propia 'existencia' [...]. En derecho administrativo la utilización de la noción de inexistencia en la jurisprudencia ha sido bastante cambiante según las épocas [...].

Entonces, hace referencia a que, aunque la decisión está presente en el mundo o la realidad (digamos, se encuentra un papel cuyo contenido tuviese apariencia de acto administrativo), por incumplimiento de los elementos de existencia (órgano, competencia y contenido), se debe entender que esta nunca nació a la vida jurídica y, por tal razón, no genera efectos sobre los coasociados (derecho u obligaciones).

Debemos reconocer que se trata de una posición complicada al ser de difícil aplicación en la vida práctica. Recordando el hipotético ejemplo anteriormente expuesto, en el cual una autoridad del sina emite una decisión para dejar sin efectos civiles un contrato matrimonial, piénsese que el particular simplemente hace caso omiso de esta por considerarla inexistente, lo cual trasladaría el examen de existencia del acto administrativo al sujeto recibo de sus efectos o a la interpretación de su operador jurídico.

${ }^{11}$ Entre ellas: usurpación de funciones o por inexistencia de estas en el ordenamiento jurídico. 
Para comprender la cuestión, citemos a Penagos (2008, p. 341):

[...] Cuando hablamos de inexistencia del acto administrativo, nos referimos a una categoría que aparentemente es acto. En cambio, cuando se dice que el acto está viciado de nulidad, se indica una decisión que existe en el mundo jurídico, pero afectada de un vicio ${ }^{12}$ [...] Lo que importa diferenciar entre el acto viciado y el inexistente es la gravedad de la irregularidad.

No puede existir, por ejemplo, un acuerdo municipal sin Concejo que lo expida, por inexistencia del órgano, así como tampoco puede existir un acto sin contenido.

La inexistencia es la nada jurídica, por ejemplo, es imposible que alguien que no es funcionario, ni esté autorizado por la ley, pueda proferir un acto administrativo [...] Un acto administrativo o una operación administrativa no pierden su carácter administrativo aunque sean irregulares [...] sin embargo, en ciertos casos la irregularidad es tan grave o tan evidente que el acto no es atribuible, ni siquiera en virtud de un vínculo dudoso [...] se dice entonces que hay 'vías de hecho'.

Con lo dicho, no debe proponerse la inexistencia de actos administrativos físicos que sean irregulares, sino la presencia de patologías que vician su vida y estabilidad jurídica. Sin embargo, cuando la decisión sea exorbitantemente irregular (como ordenar la tortura pública de un ciudadano) se tratará de una vía de hecho.

A esta conclusión llega el Consejo de Estado (sentencia del 6 de diciembre de 2012) al afirmar que "en su tratado M. de Labaudére, da una excelente puntualización de la cuestión, que resumimos como sigue: a) caso del acto absolutamente inexistente. Es el acto que no ha sido efectuado jamás o que ha sido adoptado por un individuo que no tiene la calidad de autoridad o de agente público [...] La inexistencia absoluta tiene como consecuencias que nadie puede tener en cuenta tal acto, que no es susceptible de producir ningún efecto [...]”.

En suma, el incumplimiento del 'órgano'y la 'competencia' como elementos de existencia del acto administrativo no genera que la decisión deba conside-

${ }^{12}$ Bien sea por inconstitucionalidad o por las causales generales comprendidas en la acción de nulidad descrita en el artículo 137 de la Ley 1437 de 2011. 
rarse inexistente, sino que posee vicios en su formación y, por tal razón, deberá ser controvertida ante los jueces de la república. Con lo dicho, entonces, cuando una autoridad asuma la competencia de otra, las decisiones por ella adoptadas presentarán vicios por tal razón.

Santofimio (1998, p. 350) nos cuenta que los vicios producto de la usurpación de funciones, definida por él como la “[...] intromisión grosera de un órgano u autoridad respecto de las competencias de las otras [...]", los cuales están siempre cercanos a los vicios por usurpación de autoridad o desviación de poder, en donde se asaltan temporalmente las competencias de un órgano por otro o por alguien sin la investidura para emitir los actos, serán decisiones que deben ser demandadas por cuanto no respetan lo dispuesto en el ordenamiento jurídico.

\subsection{Parte especial. De la facultad a prevención}

De la lectura de la definición de la facultad a prevención que contempla la Ley 1333 de 2009 en su artículo 2o (ya citada en la introducción) ${ }^{13}$ y de lo dicho en el aparte anterior, salta a la vista que dicha figura fue construida por fuera de la teoría general del acto administrativo, ya que está llamada a permitir el incumplimiento del elemento 'órgano' del acto administrativo. Sin embargo, aunque la reflexión propuesta no requiere mayor demostración, veamos algunas acotaciones o características de la figura de manera particular.

\footnotetext{
${ }^{13}$ Recordémosla: "Artículo 2 ${ }^{\circ}$ Facultad a prevención. El Ministerio de Ambiente, Vivienda y Desarrollo Territorial; la Unidad Administrativa Especial del Sistema de Parques Nacionales Naturales; las Corporaciones Autónomas Regionales y las de Desarrollo Sostenible; las unidades ambientales urbanas de los grandes centros urbanos a que se refiere el artículo 66 de la Ley 99 de 1993; los establecimientos públicos a los que hace alusión el artículo 13 de la Ley 768 de 2002; la Armada Nacional; así como los departamentos, municipios y distritos, quedan investidos a prevención de la respectiva autoridad en materia sancionatoria ambiental. En consecuencia, estas autoridades están habilitadas para imponer y ejecutar las medidas preventivas y sancionatorias consagradas en esta ley y que sean aplicables, según el caso, sin perjuicio de las competencias legales de otras autoridades. Parágrafo. En todo caso las sanciones solamente podrán ser impuestas por la autoridad ambiental competente para otorgar la respectiva licencia ambiental, permiso, concesión y demás autorizaciones ambientales e instrumentos de manejo y control ambiental, previo agotamiento del procedimiento sancionatorio. Para el efecto anterior, la autoridad que haya impuesto la medida preventiva deberá dar traslado de las actuaciones a la autoridad ambiental competente, dentro de los cinco (5) días hábiles siguientes a la imposición de la misma".
} 


\subsection{1. Únicamente podrá ser utilizada por algunas de las entidades del Estado. Sujeto activo de la facultad a prevención}

La Ley 1333 de 2009, que comprende como sujeto activo a aquel que detenta la posibilidad de adelantar procedimientos sancionatorios administrativos contra particulares, recae sobre las autoridades ambientales que tienen dentro de sus funciones el otorgamiento de permisos, concesiones, asociaciones, autorizaciones y licencias ambientales. Por tal razón, Rodríguez, Gómez y Monroy (2012, p. 236) expresan: "Parece prudente comprender, sin embargo, que la ley no asignó competencias sancionatorias a las entidades antes mencionadas de forma directa, por el contrario, indicó que quienes tuvieran facultades para expedir permisos, licencias y autorizaciones serán los sujetos facultados para realizar los procedimientos sancionatorios". ${ }^{14}$

Empero, la facultad a prevención posee diferentes entidades que las podrán utilizar. Veamos: reza la norma que solo podrán ejecutar las acciones relacionadas con la facultad a prevención:

a) El Ministerio de Ambiente, Vivienda y Desarrollo Territorial.En cuanto a esta descripción, debe advertirse que, a partir de la expedición de la Ley 1444 de 2011, se reordenó la institucionalidad ambiental, destacándose la creación de la Autoridad Nacional de Licencias Ambientales (ANLA) a través del Decreto-Ley 3573 de 2011 como una unidad administrativa especial, con autonomía administrativa y financiera, sin personería jurídica, adscrita al Ministerio de Ambiente y Desarrollo Sostenible, encargada de la vigilancia, inspección, seguimiento y control de los proyectos, obras o actividades sujetos a licenciamiento ambiental. Dicha autoridad cuenta entre sus funciones (numerales 1,2 y 7 del artículo 3o del Decreto-Ley 3573 de 2011) otorgar o negar las licencias, permisos y trámites ambientales de competencia del Ministerio de Ambiente y Desarrollo Sostenible, de conformidad con la ley y los reglamentos; realizar el seguimiento de las licencias, permisos y trámites ambientales; y adelantar y culminar el procedimiento de investigación, preventivo y sancionatorio en materia ambiental, de acuerdo con lo dispuesto en la Ley 1333 de 2009, sobre aquellas actividades que por

${ }^{14}$ No obstante, en los artículos 5 y 31 de la Ley 99 de 1993, y 2º del Decreto-Ley 3570 de 2011, se establecieron competencias expresas. 
competencia haya otorgado licencia, permiso o trámite ambiental, o impuesto planes de manejo ambiental.

Por tal razón, cuando la Ley 1333 de 2009 se refiere al Ministerio de Ambiente y Desarrollo Sostenible en materia permisiva debe entenderse que se está haciendo referencia a la ANLA a través de las funciones establecidas en el Decreto-Ley 3573 de 2011, salvo que se trate de acciones relacionadas con la Convención sobre el Comercio Internacional de Especies Amenazadas de Fauna y Flora Silvestres (Cites), sustracciones de reservas forestales y acceso a recursos genéticos, donde el Ministerio aún conserva la facultad sancionatoria.

b) La Unidad Administrativa Especial del Sistema de Parques Nacionales Naturales, que en el Decreto-Ley 216 de 2003 contempló que cuenta con la administración y manejo de las áreas del Sistema de Parques Nacionales y le atribuyó funciones policivas y sancionatorias.

c) Las Corporaciones Autónomas Regionales y las de Desarrollo Sostenible, que, de conformidad con lo dispuesto en el artículo 31 de la Ley 99 de 1993, comprenden facultades permisivas al ser la máxima autoridad ambiental en su jurisdicción y, por tal razón, poseen la competencia sancionatoria.

d) Las unidades ambientales urbanas de los grandes centros urbanos a que se refiere el artículo 66 de la Ley 99 de 1993. Es decir, serán los municipios, distritos o áreas metropolitanas cuya población urbana fuere igual o superior a un millón de habitantes quienes ejercerán dentro del perímetro urbano las mismas funciones atribuidas a las Corporaciones Autónomas Regionales, en lo que fuere aplicable al medio ambiente urbano.

e) Los establecimientos públicos a los que hace alusión el artículo 13 de la Ley 768 de 2002. Es decir, los distritos de Cartagena, Santa Marta y Barranquilla, que ejercerán, dentro del perímetro urbano de la cabecera distrital, las mismas funciones atribuidas a las Corporaciones Autónomas Regionales en lo que fuere aplicable al medio ambiente urbano, en los mismos términos del artículo 66 de la Ley 99 de 1993. 
f) La Armada Nacional. Siendo la entidad que más llama la atención, ya que, aunque no se encuentra como una entidad (o autoridad) ambiental, tiene la posibilidad de utilizar la figura.

Sobre el particular dos cuestiones son especiales o sui generis: la primera hace referencia a que la Ley 1333 de 2009 adjudicó la facultad sancionatoria llamada a adelantar los procedimientos del ius puniendi estatal únicamente a aquellas entidades que tienen la posibilidad de entregar, estudiar, analizar o negar los permisos, autorizaciones, asociaciones, concesiones o licencias ambientales. ${ }^{15}$ En otras palabras, tendrán las facultades de control aquellos que tengan la facultad ambiental de vigilancia, inspección y seguimiento. Por tal razón, encontrar que existen entidades del Estado que, aunque no puedan otorgar autorizaciones ambientales, puedan usar la figura objeto de estudio es sumamente inconveniente, puesto que no poseen la experticia o el conocimiento de lo que pueda llegar a considerarse una 'infracción desde el punto de vista ambiental'.

La segunda hace referencia a que, si se incluyó a la Armada Nacional, que tiene como misión contribuir a la defensa de la nación a través del empleo efectivo de un poder naval flexible en los espacios marítimo, fluvial y terrestre bajo su responsabilidad, con el propósito de cumplir la función constitucional y participar en el desarrollo del poder marítimo y la protección de los intereses de los colombianos, quien no posee competencias ambientales de vigilancia, seguimiento e inspección, por qué se dejó por fuera al resto de instituciones que hacen parte de nuestras fuerzas militares, como la Policía Nacional, el Ejército Nacional y la Fuerza Aérea Colombiana.

\footnotetext{
${ }^{15}$ Lo anterior sin desconocer que, conforme al artículo 5 de la Ley 1333 de 2009, no toda infracción ambiental es una consecuencia del incumplimiento o ausencia de una licencia, permiso autorización, concesión o asociación ambiental. Existen múltiples infracciones ambientales que no son el resultado del incumplimiento o ausencia de estas, sino, como contempla la ley, por generar un daño en sede de los elementos de la responsabilidad civil extracontractual o violentar una norma de contenido ambiental. No obstante, la competencia para adelantar los procedimientos ambientales la poseen aquellas entidades con facultades permisivas en el interior del Sistema Nacional Ambiental.
} 
g) Los departamentos, ${ }^{16}$ municipios y distritos ${ }^{17}$ (funciones establecidas en los artículos 64 y 65 de la Ley 99 de 1993). Los entes territoriales, en principio, aunque hacen parte del Sistema Nacional Ambiental (sINA), no comprenden mayores funciones sobre el particular (salvo que se trata de grandes centros urbanos). Por tal razón, en su mayoría los

\footnotetext{
${ }^{16}$ Reza el artículo 64 de la Ley 99 de 1993: "Funciones de los departamentos. Corresponde a los departamentos en materia ambiental, además de las funciones que le sean delegadas por la ley o de las que se le deleguen a los gobernadores por el Ministerio del Medio Ambiente o por las Corporaciones Autónomas Regionales, las siguientes atribuciones especiales: (1) Promover y ejecutar programas y políticas nacionales, regionales y sectoriales en relación con el medio ambiente y los recursos naturales renovables. (2) Expedir, con sujeción a las normas superiores, las disposiciones departamentales especiales relacionadas con el medio ambiente. (3) Dar apoyo presupuestal, técnico, financiero y administrativo a las Corporaciones Autónomas Regionales, a los municipios y a las demás entidades territoriales que se creen en el ámbito departamental, en la ejecución de programas y proyectos y en las tareas necesarias para la conservación del medio ambiente y los recursos naturales renovables. (4) Ejercer, en coordinación con las demás entidades del Sistema Nacional Ambiental (sina) y con sujeción a la distribución legal de competencias, funciones de control y vigilancia del medio ambiente y los recursos naturales renovables, con el fin de velar por el cumplimiento de los deberes del Estado y de los particulares en materia ambiental y de proteger el derecho a un ambiente sano. (5) Desarrollar, con la asesoría o la participación de las Corporaciones Autónomas Regionales, programas de cooperación e integración con los entes territoriales equivalentes y limítrofes del país vecino, dirigidos a fomentar la preservación del medio ambiente común y los recursos naturales renovables binacionales. (6) Promover, cofinanciar o ejecutar, en coordinación con los entes directores y organismos ejecutores del Sistema Nacional de Adecuación de Tierras y con las Corporaciones Autónomas Regionales, obras y proyectos de irrigación, drenaje, recuperación de tierras, defensa contra las inundaciones y regulación de cauces o corrientes de agua, para el adecuado manejo y aprovechamiento de cuencas hidrográficas. (7) Coordinar y dirigir con la asesoría de las Corporaciones Autónomas Regionales, las actividades de control y vigilancia ambientales intermunicipales, que se realicen en el territorio del departamento con el apoyo de la fuerza pública, en relación con la movilización, procesamiento, uso, aprovechamiento y comercialización de los recursos naturales renovables...".

${ }^{17}$ Reza el artículo 65 de la Ley 99 de 1993: "Funciones de los municipios, de los distritosy del Distrito Capital de Santafé de Bogotá. Corresponde en materia ambiental a los municipios, y a los distritos con régimen constitucional especial, además de las funciones que le sean delegadas por la ley o de las que se le deleguen o transfieran a los alcaldes por el Ministerio del Medio Ambiente o por las Corporaciones Autónomas Regionales, las siguientes atribuciones especiales: (1) Promover y ejecutar programas y políticas nacionales, regionales y sectoriales en relación con el medio ambiente y los recursos naturales renovables; elaborar los planes programas y proyectos regionales, departamentales y nacionales. (2) Dictar, con sujeción a las disposiciones legales reglamentarias superiores, las normas necesarias para el control, la preservación y la defensa del patrimonio ecológico del municipio. (3) Adoptar los planes, programas y proyectos de desarrollo ambiental y de los recursos naturales renovables, que hayan sido discutidos y aprobados a nivel regional, conforme a las normas de planificación ambiental de que trata la presente ley. (4) Participar en la elaboración de planes, programas y proyectos de desarrollo ambiental y de los recursos naturales renovables a nivel departamental. (5) Colaborar con las Corporaciones Autónomas Regionales, en la elaboración de los planes regionales y en la ejecución de programas, proyectos y tareas necesarios para la conservación del medio ambiente y los recursos naturales renovables. (6) Ejercer, a través del alcalde como primera autoridad de policía con el
} 
entes territoriales no poseen competencias para otorgar autorizaciones, concesiones, asociaciones, permisos o licencias ambientales, pero sí podrán tomar las medidas que comprende la función a prevención.

Con esto, aunque el sujeto activo de la responsabilidad ambiental en principio, y según Rodríguez, Gómez y Monroy (2012: p. 236), está representado en la Autoridad Nacional de Licencias Ambientales (ANLA), las Corporaciones Autónomas Regionales, las de Desarrollo Sostenible, las Unidades Ambientales de los Grandes Centros Urbanos, los distritos de Cartagena, Santa Marta y Barranquilla, y la Unidad Administrativa Especial del Sistema de Parques Nacionales Naturales, la facultad a prevención puede ser utilizada por entidades que no poseen facultad sancionatoria administrativa ambiental.

La razón seguramente proviene de la necesidad de contar con autoridades que puedan actuar con la inmediatez necesaria para evitar perjuicios o daños a los recursos naturales, aunque desde el punto de vista del derecho administrativo presente dificultades, ya que se está permitiendo que una autoridad (que no posee la competencia) actúe en nombre de otra que sí la tiene, o que usurpe de manera temporal sus funciones. ${ }^{18}$

apoyo de la Policía Nacional y en coordinación con las demás entidades del Sistema Nacional Ambiental (sina), con sujeción a la distribución legal de competencias, funciones de control y vigilancia del medio ambiente y los recursos naturales renovables, con el fin de velar por el cumplimiento de los deberes del Estado y de los particulares en materia ambiental y de proteger el derecho constitucional a un ambiente sano. (7) Coordinar y dirigir, con la asesoría de las Corporaciones Autónomas Regionales, las actividades de control y vigilancia ambientales que se realicen en el territorio del municipio o distrito con el apoyo de la fuerza pública, en relación con la movilización, procesamiento, uso, aprovechamiento y comercialización de los recursos naturales renovables o con actividades contaminantes y degradantes de las aguas, el aire o el suelo. (8) Dictar, dentro de los límites establecidos por la ley, los reglamentos y las disposiciones superiores, las normas de ordenamiento territorial del municipio y las regulaciones sobre usos del suelo. (9) Ejecutar obras o proyectos de descontaminación de corrientes o depósitos de agua afectados por vertimiento del municipio, así como programas de disposición, eliminación y reciclaje de residuos líquidos y sólidos y de control a las emisiones contaminantes del aire. (10) Promover, cofinanciar o ejecutar, en coordinación con los entes directores y organismos ejecutores del Sistema Nacional de Adecuación de Tierras y con las Corporaciones Autónomas Regionales, obras y proyectos de irrigación, drenaje, recuperación de tierras, defensa contra las inundaciones y regulación de cauces o corrientes de agua, para el adecuado manejo y aprovechamiento de cuencas y microcuencas hidrográficas...”.

${ }^{18}$ Sobre la usurpación de funciones, se debe aclarar que, si la ley contempla la posibilidad de usurpar las funciones, no se trata de un comportamiento por fuera del ordenamiento jurídico. No obstante, se trata de una figura particular y especial que comprende una forma que a la luz de la tradición dogmática del derecho público es conocida como 'usurpación de funciones'. 
Entonces, desde la óptica del derecho administrativo, el elemento órgano no se cumple; por tal razón, si las decisiones producto de la facultad a prevención fuesen examinadas únicamente desde el derecho administrativo, estarían viciadas de nulidad por la correspondiente usurpación de funciones u otras antes citadas. Pero el dinamismo y necesidad de protección de los recursos naturales del derecho ambiental ha generado esta especial figura que avala y permite la Ley 1333.

\subsubsection{Funciones que comprenden la facultad a prevención}

Según la norma objeto de estudio, quienes están facultados para utilizar la facultad a prevención "[...] quedan investidos a prevención de la respectiva autoridad en materia sancionatoria ambiental. En consecuencia, estas autoridades están habilitadas para imponer y ejecutar las medidas preventivas y sancionatorias consagradas en esta ley y que sean aplicables [...]", queriendo con ello establecer efectivamente cuál es su ámbito de competencia o aquello que pueden hacer.

Empero, de la lectura de esta, no es posible abstraer con claridad qué es precisamente aquello con lo cual quedan investidas dichas autoridades. Por lo cual, continuando con el contenido del parágrafo, encontramos que reza: "En todo caso las sanciones solamente podrán ser impuestas por la autoridad ambiental competente para otorgar la respectiva licencia ambiental, permiso, concesión y demás autorizaciones ambientales e instrumentos de manejo y control ambiental, previo agotamiento del procedimiento sancionatorio".

Da a entender la norma que podría el sujeto activo adelantar todo tipo de diligencias en el interior del procedimiento administrativo sancionatorio ambiental, salvo la imposición de las respectivas sanciones.

Con ello, entonces, es posible (aunque los autores no lo comparten) que una autoridad que no posee la competencia funcional para emitir un acto administrativo de carácter sancionatorio administrativo ambiental, de apertura al procedimiento, realice la formulación de los cargos, practique pruebas y otros (claro está, en caso de poder dar cumplimiento al requisito de tiempo que veremos adelante). Esto ya que la norma habla de medidas 'preventivas y sancionatorias' sin determinar qué comprende cada una de ellas. 
No obstante, las decisiones que se tomen en el interior del procedimiento sancionatorio deberían ser emitidas por su competente, so pena de estar viciadas de nulidad, siendo el ius puniendi del Estado netamente reglado.

Aunque, de un breve examen de la realidad, se ha venido reflejando en el comportamiento de las autoridades ambientales que únicamente utilizan la imposición de medidas preventivas con la facultad a prevención. Rueda (2012, p. 262) enseña que se trata de que "una autoridad adopta las medidas que resulten necesarias mientras se asegura la actuación de la autoridad a la que en principio le corresponde el ejercicio de las competencias preventivas y sancionatorios que asigna la ley".

\subsubsection{Temporalidad}

El parágrafo del artículo 2o de la Ley 1333 de 2009 plantea que la autoridad que haya tomado la decisión preventiva o sancionatoria deberá dar traslado de las actuaciones a la autoridad ambiental competente dentro de los cinco días hábiles siguientes a la imposición de esta.

Con ello, queriendo limitar el ejercicio de la facultad a prevención. Entonces, a los cinco días de la toma de la decisión o las decisiones necesarias, como se vio en el título anterior, la autoridad que no posee la competencia y que se vio obligada a actuar con el fin de evitar perjuicios al ambiente debe dar traslado a la entidad que por ley posee la función.

Se preguntará el lector qué ocurre si este término es excedido. La consecuencia natural será dar aplicación a la teoría general del acto administrativo, bajo la cual las decisiones por fuera del tiempo establecido en la ley estarán viciadas por ausencia de competencia.

Lo infortunado en la vida práctica es que quien actúa a prevención demora o dilata lo actuado y genera tanto vicios en la toma de decisiones como conflictos de competencia administrativa. Ya han existido diversas situaciones en las cuales la autoridad ambiental que usa la facultad a prevención imponiendo medidas preventivas continúa adelantando el procedimiento sancionatorio excediendo el tiempo y la competencia, obligando así al Ministerio de Ambiente y Desarrollo Sostenible a resolver conflictos administrativos de competencia. Véase como ejemplo de lo anterior el caso ventilado en la Resolución mads 390 del 12 de marzo de 2014. 


\subsubsection{Sin perjuicio de las competencias legales de otras autoridades}

Por último, la norma establece que la utilización de esta figura no disminuye la competencia de otras autoridades, lo cual es perfectamente válido si se trata de competencias no ambientales, como bien podrían ser las penales, fiscales, disciplinarias y otras.

Pero, al no restringirlo la norma, podría también darse el caso en el cual actúan dos entidades del sinA, una a prevención y otra en ejercicio de sus competencias, otorgando al caso un control concurrente, pudiendo violentar principios del debido proceso, como el non bis in idem.

Con todo lo dicho, vimos cómo la figura, aparte de estar diseñada por fuera de la teoría general del acto administrativo, también posee particularidades que la hacen única dentro del ordenamiento jurídico colombiano.

\section{Conclusiones}

Gómez (2012a, p. 263) plantea cómo

podemos afirmar que el derecho ambiental al ser una rama púber del derecho, no respeta y acata en su totalidad las reglas tradicionales de su determinador: el derecho administrativo. Como bien lo enseña Cafferatta (2004,p. 246), citando a Ojeda Mestre, lo anterior ocurre por cuanto el derecho ambiental es novedoso, situación que lo hace especial y diferente a sus congéneres.

Es posible entonces proponer [...] la creación de reglas particulares para el derecho ambiental.

Este sería el caso en el análisis de la facultad a prevención como institución propia y única del derecho sancionatorio ambiental (que no atiende además la tradición dogmática del derecho público), por cuanto:

- Es una figura legal, mediante la cual se permite que una entidad tome temporalmente competencias que la ley no le asigna, sin que por esta razón se presenten vicios en las decisiones adoptadas.

- La pueden utilizar instituciones que no son consideradas autoridades dentro del Sistema Nacional Ambiental.

- Comprende facultades no regladas en el interior del ejercicio del ius puniendi del Estado. 
Lo cual nos lleva indiscutiblemente a concluir que el derecho ambiental, dado su especial, cambiante e imperioso objeto de protección jurídica, ha venido reconociendo en su desarrollo normativo la necesidad de generar una dogmática propia que lo identifique como una rama autónoma de la disciplina jurídica.

\section{Bibliografía}

Berrocal,E. (2001). Manual del acto administrativo. Bogotá: Librería del Profesional. Colombia, Consejo de Estado, Sala de lo Contencioso Administrativo, Sección 4. Sentencia del 30 de abril de 1998. C. P.: Delio Gómez Leyva.

Colombia, Consejo de Estado, Sala de lo Contencioso Administrativo, Sala Plena. Sentencia del 9 de noviembre de 1998. C. P.: Juan Alberto Polo.

Colombia, Consejo de Estado, Sala de lo Contencioso Administrativo, Sección Cuarta. Sentencia del 6 de diciembre de 2012. C. P.: Martha Teresa Briceño de Valencia. Radicación: 25000-23-27-000-2010-00030-01 (18604). Colombia, Consejo de Estado, Sala de lo Contencioso Administrativo, Sección Cuarta. Sentencia del 6 de diciembre de 2012. C. P.: Martha Teresa Briceño de Valencia. Radicación: 25000-23-27-000-2010-00030-01 (18604).

Colombia, Corte Constitucional. Sentencia C-1007 de 2010. M. P.: Humberto Antonio Sierra Porto.

Colombia, Corte Constitucional. Sentencia C-595 de 2010. M. P.: Jorge Iván Palacio Palacio.

Colombia, Corte Constitucional. Sentencia C-742 de 2010. M. P.: Jorge Ignacio Pretelt Chaljub.

Gómez Rey, A. (2012a). La concesión de aguas superficiales en el derecho administrativo. Tendencias del derecho ambiental. Saarbrücken: EAE.

Gómez Rey, A. (2012b). Los actos administrativos inmersos en el procedimiento tendiente a obtener la concesión de aguas superficiales. Una mirada desde la tradición dogmática del derecho público. (Tesis de maestría, Universidad del Rosario, Bogotá, Colombia).

Ossa Arbeláez, J. (2009). Derecho administrativo sancionador. Una aproximación dogmática. Bogotá: Legis.

Páez Páez, I., \& Rodríguez, G. A. (2013). "Las medidas preventivas ambientales, una aproximación desde el derecho administrativo”. Revista Opinión Jurídica, 12(23), 17-30. 
Penagos, G. (2008). El acto administrativo. Tomo I. Parte general, nuevas tendencias. Bogotá: Ed. Doctrina y Ley.

Rodríguez, G. A., Gómez Rey, A., \& Monroy Rosas, J. C. (2012). Las licencias ambientales en Colombia. Una mirada desde la participación y la responsabilidad. Bogotá: Editorial Ibáñez, Universidad del Rosario y Foro Nacional Ambiental.

Rodríguez, L. (2001). Derecho administrativo, general y colombiano. Bogotá: Temis.

Rueda,M. (2012). Ley 1333 de 2009. “Muchos problemas, pocas soluciones”. En G. A. Rodríguez \& I. Páez (Eds.), Temas de derecho ambiental: una mirada desde lo público. Bogotá: Universidad del Rosario.

Santofimio Gamboa, J. O. (1998a). Tratado de derecho administrativo. Tomo I. Bogotá: Universidad Externado de Colombia.

Santofimio Gamboa,J. O. (1998b). Tratado de derecho administrativo. Acto administrativo, procedimiento, eficacia y validez. Tomo II. Bogotá: Universidad Externado de Colombia.

Vidal Perdomo, J. (1994). Derecho administrativo. Bogotá: Temis. 


\section{El seguro ecológico y la responsabilidad ambiental en Colombia}

José López Oliva*

\section{Introducción}

El Estado colombiano expide algunas normas con el propósito de prevenir, controlar y sancionar las conductas que comporten la contaminación del ambiente y, a su vez, indemnizar a las víctimas de la responsabilidad ambiental civil o estatal, a través del seguro ecológico; acto jurídico que busca, adicionalmente, la protección del patrimonio de las empresas o personas naturales, potenciales generadores de daños al medio ambiente. El objetivo del seguro ecológico, obligatorio o voluntario, no es el de mejorar y conservar los recursos naturales, así como tampoco priorizar el desarrollo sostenible o la biodiversidad del país, considerada como patrimonio nacional. La finalidad del citado seguro es salvaguardar los derechos de quien en el ejercicio de exploración y explotación de los recursos naturales pueda generar un daño ambiental; actividades catalogadas como peligrosas, donde se aplica el régimen objetivo de responsabilidad sin culpa, con una dimensión social.

La minería legal e ilegal y el transporte en todas sus modalidades son ejemplos de actividades donde se aplica la denominada 'teoría del riesgo' con

* Abogado; magíster en Derecho de la Universidad de los Andes; magíster de la Universidad Carlos III de Madrid (España); especialista en Derecho Comercial de la Universidad Pontificia Bolivariana de Medellín y en Derecho Penal y Probatorio de la Universidad del Rosario; candidato a doctor en Bioética en la Universidad Militar Nueva Granada, con pasantía de investigación doctoral en la Facultad de Derecho de la unam (México). Docente certificado a nivel internacional por la Life Office Management Asociation, Inc. - Loma, con sede en Atlanta, Georgia (EE. Uu.); tratadista y ensayista de textos de contenido socio-jurídico; profesor e investigador de la Universidad Militar Nueva Granada; director de la Línea de Investigación de Derecho de la Responsabilidad y de Seguros; conferencista nacional e internacional en Argentina, Perú, Paraguay, Bolivia, Ecuador, Panamá, Costa Rica y México. Correo electrónico: jose. lopez@unimilitar.edu.co 
presunción de responsabilidad ambiental. El propósito del presente texto es resaltar la importancia que constituye la protección constitucional y legal de los recursos naturales, y la defensa de la vida en todos sus contextos, que debe desarrollarse en un medio ambiente sano, instituido este como un derecho humano que demanda protección. Así las cosas, la protección del medio ambiente debe hacerse con el establecimiento de políticas públicas adecuadas y pertinentes. El seguro ecológico, como acto jurídico bilateral, aleatorio, oneroso y de ejecución sucesiva, tiene diversos objetivos, en los que no se incluye la protección del medio ambiente.

El presente texto es resultado de una investigación de naturaleza exploratoria de reflexión, analítica e interpretativa de tipo bibliográfico, en la que se agruparon y sistematizaron los documentos relacionados con el tema objeto de la investigación. Él revela una investigación exploratoria de revisión bibliográfica con análisis de contenido, que se desarrolla de la siguiente manera: en principio, (1) se hace alusión a las disposiciones constitucionales relacionadas con el medio ambiente y, enseguida, (2) se identifican las tensiones existentes entre la protección del medio ambiente y la explotación de los recursos naturales con un propósito económico. A su vez, se estudia (3) el régimen de responsabilidad ambiental aplicado en Colombia y se continúa con el (4) estudio y análisis del seguro ecológico dispuesto por el legislador, (5) se relacionan los intervinientes en el nombrado contrato y se realiza un breve análisis del (5.5) sistema claims made, en el seguro de responsabilidad civil por daño ambiental. Al final, se exponen las conclusiones de la investigación.

\subsection{Disposiciones constitucionales relacionadas con el medio ambiente}

En la Constitución Política de Colombia, se indica que el saneamiento ambiental es el conjunto de acciones de carácter técnico, social y económico, encaminadas a la protección de la salud, y tiene el propósito de alcanzar niveles considerables de salubridad ambiental. Dicho saneamiento comprende los procedimientos de manejo sanitario del agua potable, residual y excreta, así como también el manejo adecuado de los residuos sólidos, con el objetivo de prevenir la contaminación del ambiente y, por consiguiente, proteger la salud de las personas que cohabitan en una zona rural o urbana determinada (Constitución Política, 2013, art. 49). 
Así mismo, se instituye que el Estado debe procurar el bienestar general y la calidad de vida de las personas, y satisfacer sus necesidades de saneamiento ambiental, salud y agua potable; por lo tanto, la asignación de recursos debe ser prioritaria para la satisfacción de las citadas necesidades (Constitución Política, 2013, art. 366). A su vez, se impone al Estado y a las personas que lo integran la obligación de proteger las riquezas tanto culturales como naturales de la nación, y evitar la generación de daños derivados de responsabilidad ambiental que lesionen los intereses de las comunidades (Constitución Política, 2013, art. $\left.8^{\circ}\right) .{ }^{1}$ En suma, todas las personas que habitan el territorio nacional tienen derecho a gozar de un ambiente sano, y, por esta razón, es relevante involucrar a la población potencialmente afectada en las decisiones que puedan alterar su entorno ambiental diverso.

La diversidad de la flora y fauna existente en el país debe ser conservada; máxime cuando se trate de áreas de preservación ecológica protegidas por el Estado, y que los particulares deben preservar, razón por la cual se requiere establecer un programa de fomento y educación destinado a la población (Constitución Política, 2013, art. 79). Ciertamente, para la salvaguarda de los recursos naturales y para evitar un daño generado por responsabilidad ambiental, el Estado señala zonas de exclusión de actividades relacionadas con la explotación de canteras, carbón y minería. De forma concreta, la Corte Constitucional

\footnotetext{
${ }^{1}$ En este punto, es importante señalar lo que ha indicado la Corte Constitucional en relación con la consulta previa, que se debe agotar con las comunidades que habitan lugares de Colombia que pueden ser explotados económicamente. "En reciente pronunciamiento, esta corporación declaró la inexequibilidad de la Ley 1518 de 2012, que aprobó el 'Convenio Internacional para la Protección de Obtenciones Vegetales'. Entonces, se consideró que ha debido realizarse la consulta previa a las comunidades indígenas y afrocolombianas, toda vez que dicho convenio regulaba directamente aspectos sustanciales que conciernen a estas comunidades, en calidad de obtentores de las especies vegetales cuya propiedad intelectual se protege, tales como los criterios para reconocer la calidad de obtentor, concesión del derecho, periodicidad, condiciones de protección, reglamentación económica y utilidad que reporta la mejora y ampliación de variedades vegetales, los cuales en buena parte se considera materia de conocimientos ancestrales de estos pueblos. La Corte concluyó que la imposición de restricciones propias de una patente sobre nuevas variedades vegetales, como las que consagra el Convenio Internacional para la Protección de las Obtenciones Vegetales de 1991, podrían significar una limitación al desarrollo natural de la biodiversidad producto de las condiciones étnicas, culturales y ecosistemas propios en donde habitan dichos pueblos. De allí que este tipo de tratados y sus leyes aprobatorias están sujetas a consulta previa a las comunidades étnicas y afrocolombianas, siempre que se regulen actividades que puedan afectarlas de manera directa, procedimiento que deberá surtirse antes del sometimiento a aprobación del Congreso de la República”.
} 
[...] aclaró que las zonas de exclusión de la actividad minera no se limitaban a las áreas que integran los parques nacionales naturales, los parques naturales de carácter regional y a las zonas de reserva forestal, sino que pueden existir otras declaradas con anterioridad o que se declaren en el futuro por la autoridad ambiental [...] Por lo tanto, las autoridades ambientales pueden declarar excluidos de la minería ecosistemas tales como los páramos, así no estén comprendidos en parques nacionales o regionales o en zonas de reserva forestal. En segundo lugar, el inciso segundo fue declarado exequible en el entendido que el deber de colaboración de la autoridad minera no condiciona el ejercicio de la competencia de la autoridad ambiental (Corte Constitucional, Sent. C-443/09) (cfr. Corte Constitucional, Sent. C-339/02).

Lo consagrado por la Constitución Política de Colombia genera tensiones. Lo precedente, por la necesidad de exploración y explotación por parte del Estado o particulares de recursos naturales renovables y no renovables; actividades que pueden generar responsabilidad ambiental y son objeto de aseguramiento a través del seguro de responsabilidad civil, destinado al tomador o asegurado virtual dañador del medio ambiente. Póliza que tiene como objetivo indemnizar los perjuicios causados a las víctimas por la alteración del medio ambiente, y no la salvaguarda de este.

\subsection{La tensión existente entre la protección del medio ambiente y la explotación económica de los recursos naturales}

La problemática generada en el medio ambiente se incrementa en los países en vía de desarrollo, donde sus habitantes reclaman una existencia humana digna, con alimentación adecuada, educación y un servicio de salud eficiente. De ahí la necesidad de dirigir los esfuerzos de los países desarrollados para generar equidad y salvaguardar el medio ambiente, principalmente cuando el proceso de industrialización y el desarrollo tecnológico pueden desequilibrar el ambiente sano (onu, 1972). Por este hecho, el sector industrial debe tomar las medidas necesarias para prevenir los daños a las personas, y no únicamente indemnizar los perjuicios a través de compañías aseguradoras, a quienes se les traslada el riesgo inherente a la actividad fabril. 
Es más rentable explotar los recursos naturales y pagar el daño ambiental con capitales propios o por medio del sistema de seguros, lo que no puede ser una estrategia económica válida. El concepto de calidad de vida desde lo económico-cuantitativo no justifica la explotación y degradación del medio ambiente, sino que debe concentrarse en la neutralización de las diferencias sociales existentes en la actualidad. De la citada degradación emerge el derecho ambiental, que tiene un carácter preventivo, sistémico, interdisciplinario y transversal, el cual propende por la distribución equitativa del costo-beneficio, con una propuesta integradora, dinámica y diversa (Jaquenod de Zsögön, 2004, p. 198). ${ }^{2}$ La interdisciplinariedad se observa en el carácter preventivo del derecho ambiental, los tratados, los convenios y todas las conferencias relacionadas con la función de regulación y sanción de conductas, para reprimirlas cuando estas atenten contra el medio ambiente.

\subsubsection{La Conferencia de Estocolmo y la protección del medio humano}

La Conferencia de las Naciones Unidas sobre el Medio Humano, más conocida como 'Conferencia de Estocolmo', se instituyó en un evento de relevancia para discutir temas relacionados con el medio ambiente y la incorporación de una política ambiental en el ámbito internacional. El citado evento fue el primero en orientar la agenda ambiental de la onu y de la comunidad internacional. No obstante, fue imposible la consecución de acuerdos relacionados con la protección de los bosques, la población, la regulación de la energía y de los patrones de producción y consumo (Cherni, 2006, p. 4); lo precedente, por la generación de tensiones entre el derecho a explotar los recursos naturales y la protección del medio ambiente.

\footnotetext{
2 "Lo sistémico alude a que la concepción, dinámica, dimensión y normas en general, están al servicio de la regulación de los distintos elementos, fenómenos y procesos naturales, sociales y culturales que componen el ambiente. Un sistema se caracteriza por un conjunto de elementos relacionados entre sí y por el carácter de totalidad del conjunto". "Es interdisciplinario y transversal, porque en él se yuxtapone una amplia gama de disciplinas más o menos relacionadas. Esta interdisciplinariedad se articula dentro de un marco de importación de conceptos, procedimientos, metodologías, aplicándose técnicas de un campo y adaptándolas a otros. Un auténtico derecho ambiental abordará las diferentes situaciones ambientales desde la interdisciplinariedad, protegiendo el ambiente desde un enfoque con amplias bases de colaboración científica, captando la diversidad de ciencias y de ramas jurídicas" (Jaquenod de Zsögön, 2004, p. 198).
} 


\subsubsection{Los principios que orientan la protección del medio ambiente en Colombia}

El Estado colombiano profiere normas que buscan prevenir y controlar la contaminación ambiental, y adicionalmente mejorar y conservar los recursos naturales. Así mismo, la política dirigida a la protección del medio ambiente en Colombia incorpora los principios universales relacionados a continuación: en primer lugar, se debe priorizar el desarrollo sostenible; en segundo lugar, se revela que la biodiversidad del país es considerada patrimonio nacional y de interés global; y, por último, se dispone que la vida saludable y productiva del ser humano es un derecho que debe ser salvaguardado. Igualmente, se establece que

[...] 4. Las zonas de páramos, subpáramos, los nacimientos de agua y las zonas de recarga de acuíferos serán objeto de protección especial.5. En la utilización de los recursos hídricos, el consumo humano tendrá prioridad sobre cualquier otro uso. 6. La formulación de las políticas ambientales tendrá en cuenta el resultado del proceso de investigación científica. No obstante, las autoridades ambientales y los particulares darán aplicación al principio de precaución conforme al cual, cuando exista peligro de daño grave e irreversible, la falta de certeza científica absoluta no deberá utilizarse como razón para postergar la adopción de medidas eficaces para impedir la degradación del medio ambiente. 7. El Estado fomentará la incorporación de los costos ambientales y el uso de instrumentos económicos para la prevención, corrección y restauración del deterioro ambiental y para la conservación de los recursos naturales renovables (Chavarro, 2010, p. 8). ${ }^{3}$

E1 Estado previene, corrige y restaura el medio ambiente alterado, porque es patrimonio común, y tanto aquel como los particulares están obligados a participar de forma activa en su conservación; medio ambiente que está

3 “[...] recursos naturales renovables, a saber: 1. La atmósfera y el espacio aéreo nacional. 2. Las aguas en cualquiera de sus estados. 3. La tierra, el suelo y el subsuelo. 4. La flora". "El Presidente de la República de Colombia, en ejercicio de las facultades extraordinarias conferidas por la Ley 23 de 1973 y previa consulta con las comisiones designadas por las cámaras legislativas y el Consejo de Estado, dicta el Código Nacional de Recursos Naturales Renovables y de Protección al Medio Ambiente" (Congreso de la República, Decreto 2811 de 1974). 
conformado por la atmósfera y los recursos naturales renovables. Los citados recursos tienen la facultad de regenerarse a través de procesos naturales, a menos que el ser humano y circunstancias externas no permitan la posibilidad de regeneración; es el caso de la caza de animales en vía de extinción, o la tala indiscriminada de árboles. Al mismo tiempo, "[...] se consideran bienes contaminables el aire, el agua y el suelo" (Congreso de la República, Ley 23 de 1973, art. $\left.3^{\circ}\right) ;{ }^{4}$ bienes que un seguro ecológico no puede proteger de manera integral, porque lo amparado es el patrimonio del asegurado, quien puede ser, por ejemplo, un transportador marítimo causante de responsabilidad ambiental.

\subsubsection{Safety Management Code y el transporte marítimo de personas y mercancías}

Existen diferentes tipos de transporte de mercancías y pasajeros que contaminan el medio ambiente por donde transitan: los transportes aéreo, terrestre, fluvial, lacustre, multimodal y marítimo, se reitera, son generadores de daño ambiental; para el último caso, la Organización Marítima Internacional ${ }^{5}$ instituye el denominado Safety Management Code, que regula los niveles de contaminación generada por las naves en su trayecto. Se dispone en el citado Code que el armador debe obtener la certificación con vigencia anual, documento que debe indicar el cumplimiento de las reglas establecidas para el transporte de pasajeros, tanqueros, químicos, granos, petróleo, entre otros (Narváez, 2000, p. 80). Transporte considerado una actividad peligrosa, que

\footnotetext{
${ }^{4}$ Por la cual se conceden facultades extraordinarias al Presidente de la República para expedir el Código de Recursos Naturales y Protección al Medio Ambiente y se dictan otras disposiciones.

${ }^{5}$ As a specialized agency of the United Nations, IMO is the global standard-setting authority for the safety, security and environmental performance of international shipping. Its main role is to create a regulatory framework for the shipping industry that is fair and effective, universally adopted and universally implemented [...] In other words, its role is to create a level playing-field so that ship operators cannot address their financial issues by simply cutting corners and compromising on safety, security and environmental performance. This approach also encourages innovation and efficiency [...] Shipping is a truly international industry, and it can only operate effectively if the regulations and standards are themselves agreed, adopted and implemented on an international basis. And IMO is the forum at which this process takes place". The International Maritime Organization is the United Nations specialized agency with responsibility for the safety and security of shipping and the prevention of marine pollution by ships. Recuperado de http://www.imo.org/About/Pages/Default. aspx
} 
debe contar con una póliza de responsabilidad civil contractual y extracontractual de carácter obligatorio.

El transporte de mercancías denominadas 'azarosas', es decir, combustibles, productos inflamables, entre otras, implica un peligro inminente, pero, por su naturaleza y características, generan un alto índice de rentabilidad para el transportador y el titular de las mercancías. Los siniestros de incendio, volcamiento, explosión, emisión radiactiva, entre otros, producen degradación del lugar donde ocurren, por esto, se requiere un transporte y almacenamiento con extremas medidas de seguridad (Mapfre, 2014). En suma, el contrato de transporte marítimo comporta riesgos inherentes a su actividad, porque en el trayecto o aun fuera de él pueden presentarse naufragios, averías y eventos adversos que producen daños ambientales sufragados por el asegurador. Ciertamente,

[...] las mayores catástrofes han sido siempre protagonizadas por grandes petroleros que, por diversas razones, han vertido miles de toneladas de petróleo al mar. Si bien en las primeras épocas de la navegación el seguro hacía referencia a la carga, al buque y al flete principalmente, y el principio de libertad de los mares ha evolucionado y sufrido una serie de importantes limitaciones. En 1609 el holandés Grotius fue el primero en proclamar la libertad de los mares, quedando limitadas las aguas territoriales a unas tres millas marinas de la costa. La cobertura de los seguros marítimos se ha ido extendiendo a los daños ambientales en cuanto a los recursos naturales per se, a la recuperación del área afectada y a la indemnización de las víctimas (Jaquenod de Zsögön, 2004, p. 233).

Finalmente, la degradación del ecosistema marítimo y forestal afecta significativamente la supervivencia normal de las especies. Los animales dependen del mar, el bosque y las plantas, que, al ser deforestadas, alteran el hábitat, y, por ende, sus habitantes tienen a desintegrarse por la modificación de los microclimas existentes, la aparición de tiempo seco y la proliferación de plagas (Jaquenod de Zsögön, 2004, p. 237). Puede existir un código de seguridad marítimo y un seguro ecológico que cubra los perjuicios generados por la responsabilidad ambiental, pero, si al hacer la ponderación entre la economía y la protección 
del medio ambiente prima la primera, las normas reglas y principios que se expidan para la protección del medio ambiente son insignificantes.

\subsection{El régimen de responsabilidad ambiental aplicado en Colombia}

Colombia es un país ubicado en Sudamérica, con abundante biodiversidad; la biodiversidad está relacionada con la variedad de especies que hacen presencia en una dimensión espacio-temporal, y que, a su vez, interactúan, se integran, se adaptan y evolucionan en un medio ambiente específico (Ñque, 2010, p. 3). No obstante, se evidencia, en principio, la ausencia de programas educativos y políticas de Estado que permitan la protección de las especies existentes en el país, y la falta de sanciones ejemplarizantes que modifiquen la conducta de quien degrada el medio ambiente. Sanciones donde se aplique el régimen objetivo de responsabilidad con dimensión social, es decir, con la incorporación de la presunción de responsabilidad derivada del daño ambiental. ${ }^{6}$

\subsubsection{La Revolución Industrial y el medio ambiente}

La temática relacionada con el medio ambiente surge en la década de los setenta por el acelerado crecimiento de la economía, sobre todo en los países industrializados. La expansión de la industria, la actividad minera y la economía siempre ligada con el desarrollo del hombre (Jaquenod de Zsögön, 2004, p. 241) $)^{7}$ generó problemas ambientales que se analizan de forma permanente por la comunidad internacional y por los Estados involucrados en el daño,

\footnotetext{
${ }^{6}$ Así mismo, Colombia es un país ubicado en el extremo nororiental de América del Sur, tiene costas en los océanos Pacífico y Atlántico, con dos períodos de lluvia: la primera de abril a junio y la segunda de agosto a noviembre. Este país comparte fronteras con Ecuador, Perú, Venezuela, Brasil, Perú y Panamá, así como tiene límites marítimos con República Dominicana, Haití, Jamaica, Nicaragua, Costa Rica y Honduras. Este hecho hace que se generen conflictos con los países vecinos; un ejemplo de lo afirmado es el conflicto entre Ecuador y Colombia por el uso de glifosato, herbicida utilizado para el control de cultivos ilícitos.

7 "Los minerales han estado siempre ligados a la evolución de la humanidad, ello al punto que a las diferentes etapas prehistóricas se las identifica con nombres de distintos minerales, y aunque éstas no comenzaron al mismo tiempo en todos los continentes, se las conoce como Edad de Piedra, Edad de Bronce, Edad de Cobre, Edad de Hierro, Edad del Petróleo. En la Edad de Piedra puede que el ser humano ya hubiera descubierto el carbón; pero es recién en el siglo xvi, cuando a consecuencia de la desaparición de los bosques, se utiliza como fuente de energía" (Jaquenod de Zsögön, 2004, p. 241).
} 
quienes trasladan los riesgos de sus actividades a una compañía aseguradora. Empresa que expide en la actualidad el denominado seguro ecológico.

Adicionalmente, se evidencia que los avances tecnológicos y científicos fueron utilizados, en principio, para la industria bélica, y, posteriormente, fueron direccionados a la eficacia en la producción masiva de bienes y servicios públicos (Jankilevich, 2003, p. 5). Así mismo, la Revolución Industrial introdujo un cambio en la relación laboral, con la necesidad de suscribir el seguro de responsabilidad para empleadores, virtuales causantes de daños a los trabajadores. En suma,

las condiciones del trabajo van a constituir un ineludible soporte para los grupos de trabajadores hacinados en los centros fabriles y ciudades industriales de reivindicaciones, que se orientarán hacia unas demandas de las condiciones de vida más saludables y menos contaminadas. La degradada situación afectaba en mayor medida a cuyas condiciones agudización de los de vida eran penosas [sic]. Ha de admitirse que, en la Revolución Industrial, se han producido efectos negativos como la polución atmosférica y de las aguas, las enfermedades de los obreros contraídas en larguísimas jornadas de trabajo, la agudización de los antagonismos sociales y otras varias dedicadas al estudio de esta época histórica. En circunstancias concretas, a corto plazo, hubo cierta recesión en el nivel de vida de las gentes (Delfín, 2011, pp. 37-38). ${ }^{8}$

Al mismo tiempo, se puede afirmar que la estructuración del régimen objetivo de responsabilidad civil derivada de la contaminación ambiental surge de convenios internacionales donde se discutieron temas relacionados con la energía nuclear, la contaminación por hidrocarburos de aguas marinas,

\footnotetext{
8 "El humo oscureció los cielos de Manchester y Birmingham, y la vida en las ciudades se hizo más triste. Las pequeñas villas industriales, tales como Oldham o Bilston, cobraron un aspecto hostil; [...] Hubo también, según parece, una decadencia del gusto, tal como los mismos tipos de imprenta, empleados en los libros, que han de consultarse lo demuestra [...] Mucho se ha escrito sobre los efectos de la Revolución Industrial en los obreros. Gran parte de los historiadores, impresionados por el número de los que perecieron en su lucha contra la máquina, han declarado que los cambios técnicos trajeron poco más que miseria y pobreza" (Asthon, 1989, p. 89; Díaz, 2011, pp. 37-38).
} 
entre otros (Galvis, 1999). ${ }^{9}$ La aplicación de la responsabilidad civil objetiva, es decir, sin culpa, expresa las relaciones de intercambio de una sociedad individualista que busca la explotación y comercialización de bienes y servicios, causando daño al ambiente sano, instituido como un derecho humano. En suma, la responsabilidad por el hecho dañoso lícito o ilícito "[...] se consagra en función del individuo y de su capacidad como ente racional y autónomo para responder de sus actos cuando éstos lesionan, sea dolosa o culposamente, el derecho de otro" (Jaquenod de Zsögön, 2004, p. 229).

\subsection{E1 seguro ecológico}

La primera expresión del seguro ambiental o ecológico, como se le denomina en Colombia, se presenta en los Estados Unidos de Norteamérica en la década de los setenta, a través de la mencionada National Environmental Policy Act. ${ }^{10}$ El propósito de la citada norma era procurar el respeto del medio ambiente y el aseguramiento del riesgo ambiental por parte de las empresas con mayor desarrollo industrial, quienes se constituían en las tomadoras o aseguradas de la póliza de responsabilidad civil. Es importante advertir que los aseguradores no exigían garantías ${ }^{11}$ a sus clientes, porque el daño ambiental se consideraba un siniestro que no representaba mayores consecuencias para la compañía de seguros (Pinilla, 2003, pp. 157-179).

El riesgo que una vez exteriorizado se convierte en siniestro ambiental se encontraba incorporado en una cláusula adicional al seguro de daños patrimoniales, en el ramo de responsabilidad civil; riesgo derivado de la actividad

\footnotetext{
${ }^{9}$ Cabe anotar, además, que en Italia el Ministerio del Medio Ambiente fue creado por la Ley $8^{a}$ de 1986 y a ella se incorporaron disposiciones de responsabilidad por daños al medio ambiente. Alemania, por su parte, expidió en 1990 la Ley 10, para regular también la responsabilidad ambiental. Se establece entonces que, "en el mundo, la preocupación por estructurar un régimen de responsabilidad civil por contaminación ambiental data del año de 1960: el Convenio de París del 2Q de junio, en el que se incorporó un régimen para el sector de la energía nuclear, y la ley española del 29 de abril de 1964, que hizo viable la cobertura de riesgos nucleares reglamentada a través del decreto del 22 de junio, así lo corroboran; por su parte, el Convenio de Bruselas del 29 de noviembre de 1969, relativo a la contaminación por hidrocarburos de las aguas marinas, así lo demuestra. Francia incorporó una ley en este sentido en el año 1977, Italia lo hizo en 1980, Alemania en 1982, Holanda en 1984, Estados Unidos en 1985 y Dinamarca en 1992" (Galvis, 1999).

${ }^{10}$ Ley de Política Nacional Ambiental, expedida en 1969.

${ }^{11}$ Las garantías en favor del asegurador las constituyen la prenda, la hipoteca o, en su defecto, las obligaciones impuestas a cargo del tomador o asegurado, por ejemplo, la instalación de alarmas o la vigilancia armada.
} 
industrial, es decir, de naturaleza peligrosa donde se aplica la denominada teoría del riesgo. En síntesis,

la teoría del riesgo genera una tendencia, que se mantiene en todos los ámbitos del derecho (excepto el penal), hacia la consagración de la responsabilidad objetiva, que permite la reparación sin que pueda atribuirse una conducta antijurídica directa a quien resulta condenado, y se amplía el concepto, eliminando la condición del beneficio económico para incluir así todas las actividades peligrosas cualquiera sea la razón para que alguien las esté realizando. Pero hay más, se han identificado casos en que la ocurrencia del daño da lugar a la reparación, sin que exista la posibilidad de eximirse, tratando de desvirtuar el nexo o la culpa de la víctima, en lo que se denomina una responsabilidad objetiva plena (Medina, 2009, p. 165). ${ }^{12}$

El derecho comercial, y concretamente el derecho de seguros, sumado al derecho de daños con énfasis en responsabilidad ambiental y la aplicación del régimen objetivo con dimensión social, contribuye a garantizar los derechos a la verdad, a la justicia y a la reparación integral de las víctimas del daño al medio ambiente (Jaquenod de Zsögön, 2004, p. 229). ${ }^{13}$ De un lado, el legislador

${ }^{12}$ En Chile, "[...] no existe una póliza diseñada específicamente para cubrir la responsabilidad por daño ambiental, pero su cobertura opera a través de las antedichas cláusulas adicionales. Importante es hacer revisar lo contenido en la póliza de responsabilidad civil (conocida comúnmente como modelo suizo) y su cláusula de cobertura adicional de responsabilidad civil por contaminación asimilada de NMA 1685 (Lloyd's Non Marine Association), las que en la práctica asegurativa son las más utilizadas. No obstante, se debe advertir que, desde la vigencia de la póliza de responsabilidad antedicha, han sido aprobadas por la Superintendencia de Valores y Seguros otras pólizas de responsabilidad civil con su cláusula adicional de cobertura de responsabilidad civil por contaminación, las cuales son de escasa utilización y conocimiento en el mercado asegurador" (Cfr. POL 191086 Res. 236 del 31/12/1991. Compañía de Seguros Generales Euroamérica S.A. Póliza de responsabilidad civil. Modificada por Res. 44 de 27/03/1992. Cfr. CAD 197010. Res. 211 del 17/07/1997. Asociación de Aseguradores de Chile A.G. Cobertura de responsabilidad civil por contaminación asimilada de NMA 1685. Lloyd's Non Marine Association. Cfr. Pol 197008. Res. 211 del 17/07/1997. Asociación de Aseguradores de Chile A.G. Póliza de responsabilidad civil. Cfr. cad 197009. Res. 211 del 17/07/1997. Asociación de Aseguradores de Chile A.G.Cobertura de responsabilidad civil por contaminación, adicional a: póliza de responsabilidad civil POL 197008).

13 "La evolución del derecho comercial o mercantil ha sido paralela al desarrollo del comercio, en esta dinámica el derecho comercial o mercantil se va adaptando progresivamente y sin interrupción a las nuevas realidades y necesidades comerciales. La primera compilación de normas comerciales que se 
expide normas que integran los derechos civil y comercial, con el objeto de crear los seguros ecológicos que permiten cubrir los perjuicios patrimoniales y extrapatrimoniales de la víctima, causados por el daño al ambiente y a los recursos naturales (Congreso de la República de Colombia, Código Penal, 1999). De otro lado, el poder legislativo incorpora reformas al Código Penal en lo atinente a los delitos ambientales (Congreso de la República de Colombia, Código Penal, 1999, arts. 14-24). ${ }^{14}$

Así, el derecho penal consagra normas que protegen los recursos naturales, que son insustituibles y, por tal razón, se “[...] define ontológicamente la categoría del delito ambiental, puesto que sin lugar a duda constituye un delito que atenta contra las bases mismas de la vida, de la subsistencia del mundo orgánico, de la permanencia del mundo inorgánico y, globalmente, de la existencia de todos los seres" (Jaquenod de Zsögön, 2004, p. 230).

\subsubsection{Objetivo de la celebración de un contrato de seguro ecológico}

El seguro ecológico protege el patrimonio del tomador o asegurado, y garantiza el pago de la indemnización a la víctima de la responsabilidad ambiental, pero no previene que el daño se manifieste, es decir que el siniestro se realice. Por este motivo, es relevante adoptar medidas apropiadas para ser aplicadas en el ámbito nacional e internacional, tendientes a proteger de forma eficaz el medio ambiente (Rodríguez, Narran y Alonso, 1997, p. 7). La nombrada protección debe provenir del Estado, quien tiene la obligación, por una parte, de abstenerse de causar daños irreversibles al medio ambiente y, por otra, de adoptar las medidas necesarias y razonables para regular el comportamiento

conoce es la Lex Rhodia, la cual hace sólo referencia al derecho comercial o mercantil de la navegación. Esta fue confirmada por varios emperadores, así como en un Edicto de Antonino: 'Yo soy dueño del mundo entero, pero la mar está sometida a las leyes. Este negocio debe ser juzgado por la Ley Rodia, que se refiere al comercio marítimo, mientras esta ley no sea contraria a nuestras ordenanzas" (Jaquenod de Zsögön, 2004, p. 229).

${ }^{14}$ La norma expedida por el Congreso ha modificado normas relativas a las siguientes conductas consideradas como punibles: incendio, daño en obras de defensa común, provocación en inundación o derrumbe, tenencia, fabricación y tráfico de sustancias u objetos peligrosos. Así mismo, la norma crea nuevas conductas punibles con el objetivo de salvaguardar el medio ambiente, como las siguientes: ilícito aprovechamiento de recursos biológicos, invasión de áreas de especial importancia ecológica, explotación o exploración ilícita minera o petrolera, manejo ilícito de microorganismos nocivos, manejo ilícito de microorganismos nocivos, omisión de información, contaminación ambiental (cfr. Congreso de la República de Colombia, Código Penal, 1999, arts. 14-24). 
de las personas naturales y jurídicas, potenciales causantes de daños al ambiente. Por consiguiente, “[...] esta obligación implica el deber de los Estados de generar un sistema normativo que obligue a los particulares a no dañar el ambiente, así como de instituir políticas que permitan el control del cumplimiento de tales disposiciones" (Corte Constitucional, Sent. T-851/10).

En este orden de ideas, el objetivo de contratar un seguro ecológico es salvaguardar el patrimonio del tomador o asegurado, quien es potencial generador de daños en la explotación de recursos naturales o en actividades como el transporte. Es decir, el interés asegurado protegido no es el patrimonio de la víctima, sino del victimario contaminador del ambiente, sobre quien pueden recaer procesos judiciales donde se demanda la obligación de indemnizar los perjuicios causados a terceros. Se reitera que otro objetivo del seguro ecológico es garantizar la indemnización integral a cargo del asegurador por los perjuicios generados a la víctima del daño ambiental. Los perjuicios pueden ser originados por dos situaciones: la primera, por los daños al ambiente y a los recursos naturales para los efectos del seguro de responsabilidad civil extracontractual imputable al tomador o asegurado; y la segunda, en el evento de la afectación de los seguros de daños reales, originados en "[...] un hecho accidental, súbito e imprevisto de la acción de un tercero o por causas naturales" (Congreso de la República de Colombia, Código Penal, 1999).

\subsubsection{Características del seguro ecológico}

El seguro ecológico es un contrato consensual, donde impera la voluntad del tomador o asegurado y de la compañía de seguros, quienes celebran el acto jurídico de acuerdo con las condiciones generales y particulares establecidas en la póliza; acto jurídico caracterizado por ser bilateral y a la vez pluripersonal, porque actúan dos partes y una pluralidad de personas naturales o entes jurídicos, que convienen en la celebración del contrato; convención donde una parte traslada el riesgo a la compañía de seguros, a cambio del pago de una prima. $\mathrm{El}$ precio del seguro o prima hace del seguro un acuerdo oneroso y, a la vez, aleatorio, porque siempre el tomador está obligado a pagar el precio del seguro, pero no siempre la compañía tiene el deber de pagar el siniestro, a menos que este ocurra dentro de la vigencia del contrato; vigencia que hace que el contrato sea de ejecución tracto sucesiva, puesto que a cada instante el riesgo por daño ambiental está latente. 


\subsubsection{Clases de seguro ecológico}

Las clases de seguro ecológico en Colombia son dos: el obligatorio y el voluntario. Antes de hacer referencia a cada una de las clases del citado seguro, es importante señalar que las tendencias relacionadas con la protección de los recursos naturales iniciaron con la fundación del Club de Roma, ${ }^{15}$ creado con el objetivo de generar conciencia en las personas acerca del problema ecológico. El estudio realizado por la mencionada fundación evidencia que la base del inconveniente del daño ambiental es producto de la ignorancia de las personas acerca de temas relativos a la ecología y su papel en la Tierra, la relación con el medio ambiente y su cuidado. El ser humano prioriza sus necesidades, orientadas principalmente en "[...] la economía, la tecnología, los estilos de vida, y la misma política" (Gamboa, 2011, p. 3), dejando en un segundo plano la protección del medio ambiente. En este orden de ideas, se enfatiza que el seguro ecológico obligatorio o voluntario no protege el medio ambiente ni previene el daño ambiental, tal como se demuestra a continuación.

\subsubsection{El seguro ecológico obligatorio}

El legislador colombiano ha establecido un seguro ecológico con carácter obligatorio para quienes desarrollan actividades humanas que puedan generar daños al medio ambiente. Es una póliza que la norma exige en actividades donde es obligatoria la expedición de una licencia ambiental; esta es un documento público requerido por el Estado al proponente de un proyecto por la ejecución de una obra pública o la prestación de un servicio en favor del Estado (DAFP, 2011).16 El seguro ecológico obligatorio se puede 'homologar' con la

15 “El Club de Roma es una organización independiente sin ánimo de lucro. Su trabajo se centra en las principales causas que explican los retos y crisis que atraviesa el planeta en la actualidad: los conceptos actuales de crecimiento, desarrollo y globalización. El Club de Roma funciona como plataforma que congrega a académicos, científicos, políticos, hombres de negocios y funcionarios para diseñar, desarrollar y poner en marcha modelos de actuación eficaces para tratar numerosos asuntos de alcance mundial que se hayan relacionados, como la sustentabilidad medioambiental, el crecimiento económico , el consumos de recursos, la paz, la seguridad y la demografía mundial. La Secretaría General del Club se encuentra en Winterthur, Suiza”. Recuperado de http://www.clubofrome.org/?p=4773

16 "La Autoridad Nacional de Licencias Ambientales (ANLA) es la encargada de que los proyectos, obras o actividades sujetos de licenciamiento, permiso o trámite ambiental cumplan con la normativa ambiental, de tal manera que contribuyan al desarrollo sostenible ambiental del país [...]”. Funciones artículo 3ㅇ, Decreto 3573: "La Autoridad Nacional de Licencias Ambientales (ANLA) cumplirá las siguientes funciones: [...]1. Otorgar o negar las licencias, permisos y trámites ambientales de competencia del Ministerio de Ambiente y Desarrollo Sostenible, de conformidad con la ley y los reglamentos [...] 
póliza de responsabilidad civil extracontractual que haya suscrito el tomador del seguro con la obligación de tramitar la licencia ambiental, y, por ende, no es obligatoria la suscripción del seguro ecológico. La 'homologación' es verificada por la autoridad ambiental respectiva, con el propósito de establecer “[...] que efectivamente tenga las coberturas y los montos asegurados adecuados” (Congreso de la República de Colombia, Código Penal, 1999, art. 3º).

En este orden de ideas, el legislador impone la obligación de la suscripción del seguro ecológico, porque el hombre es un ser que afecta permanentemente el medio ambiente. Por este hecho, nace lo que algunos tratadistas han denominado 'la ecología humana', que es la disciplina encargada de la recopilación, estudio e interpretación de la relación del ser humano en su entorno con el ecosistema del planeta. La citada relación no únicamente es enunciada, sino aplicada a "[...] la incidencia de factores que el hombre introduce, que apriorísticamente no sólo perturban la relación natural, sino que los enfrenta con factores de riesgo de vida" (Ghersi, 1995, pp. 110-111).

A su vez, la norma impone una multa a quien estando obligado se abstiene de contratar la póliza de seguro de responsabilidad civil, que ampara los riesgos al medio ambiente. Así mismo, es acreedora de la multa la persona natural o jurídica que haya suscrito el seguro ecológico pero que este carezca

2. Realizar el seguimiento de las licencias, permisos y trámites ambientales [...] 3. Administrar el Sistema de Licencias, Permisos y Trámites Ambientales (siLA) y Ventanilla Integral de Trámites Ambientales en Línea (Vital) [...] 4. Velar porque se surtan los mecanismos de participación ciudadana de que trata la ley relativos a licencias, permisos y trámites ambientales [...] 5. Implementar estrategias dirigidas al cuidado, custodia y correcto manejo de la información de los expedientes de licencias, permisos y trámites ambientales [...] 6. Apoyar la elaboración de la reglamentación en materia ambiental [...] 7. Adelantar y culminar el procedimiento de investigación, preventivo y sancionatorio en materia ambiental, de acuerdo con lo dispuesto en la Ley 1333 de 2009 o la norma que la modifique o sustituya [...] 8. Adelantar los cobros coactivos de las sumas que le sean adeudadas a la Autoridad Nacional de Licencias Ambientales (ANLA) por todos los conceptos que procedan [...] 9. Ordenar la suspensión de los trabajos o actividades, en los casos en los que el Ministerio de Ambiente y Desarrollo Sostenible haga uso del ejercicio discrecional y selectivo sobre los asuntos asignados a las Corporaciones Autónomas Regionales [...] 10. Aprobar los actos administrativos de licencias ambientales para explotaciones mineras y de construcción de infraestructura vial y los permisos y concesiones de aprovechamiento forestal de que tratan los artículos 34, 35 y 39 de la Ley 99 de 1993 [...] 11. Dirimir los conflictos de competencia cuando el proyecto, obra o actividad sujeto a licencia o permiso ambiental se desarrolle en jurisdicción de dos o más autoridades ambientales [...] 12. Desarrollar la política de gestión de información requerida para el cumplimiento de su objeto [...] 13. Asumir la representación judicial y extrajudicial de la nación en los asuntos de su competencia [...] 14. Las demás funciones que le asigne la ley" (Departamento Administrativo de la Función Pública, 2011). 
de vigencia o del amparo requerido por la norma. En síntesis, "[...] quien estando obligado a contratar la póliza ecológica y no contare con ella o no estuviese vigente, al momento de la ocurrencia del daño, podrá ser multado por la respectiva autoridad ambiental hasta por el equivalente a la mitad del costo total del daño causado" (Congreso de la República de Colombia, Código Penal, 1999, art. 11).

\subsubsection{Seguro ecológico voluntario}

En principio, es importante indicar que el derecho agrario ha sido catalogado desde sus orígenes como un derecho de naturaleza social, que busca transformar la estructura agraria nacional de carácter latifundista a minifundista, pero con un alto nivel de eficacia. El nombrado derecho agrario trata de modificar un sistema de relación 'hombre-hombre', es decir, un vínculo netamente social y económico, en una relación 'ser humano-naturaleza'. La primera relación tiene un régimen de apropiación del suelo y los recursos naturales, gobernado "[...] por la injusticia social y la ineficiente e irracional explotación de los factores de producción"(Jaquenod de Zsögön, 2004, p. 35). En las actividades realizadas en el citado régimen de apropiación, se generan riesgos que son trasladados de manera voluntaria por el potencial dañador a una compañía aseguradora a cambio del pago de una prima.

En Colombia, es viable la celebración de un contrato de seguro ecológico de forma voluntaria, al igual que en el continente europeo, donde la póliza se manifiesta, de un lado, desde el seguro de daños reales, que incluye incendio y terremoto, por ejemplo, y, de otro lado, a través del seguro de daños patrimoniales de responsabilidad civil de tipo contractual o extracontractual, la última derivada principalmente de accidentes nucleares (Pinilla, 2003, pp. 157-179). Así las cosas, el seguro ecológico de suscripción voluntaria lo puede contratar un particular o una entidad oficial o privada, con el objetivo de amparar los perjuicios económicos generados por el daño ecológico a sus bienes e intereses patrimoniales. Para que exista cobertura, el daño debe ser "[...] producido por un hecho accidental, súbito e imprevisto, por la acción de terceros o por causas naturales" (Congreso de la República de Colombia, Código Penal, 1999, art. 4\%).

En suma, el seguro ecológico voluntario no procura la protección de todas las especies que hacen parte del ecosistema, conformado por la flora, la fauna, el aire, el suelo y el agua, entre otros, que se incorporan de forma armónica 
en el medio físico donde se desarrollan; se evidencia que todas las especies deben ser protegidas y no únicamente el género humano (Narváez, 2000, p. 80), quien tiene la potestad de asegurar su patrimonio contratando un seguro ambiental o ecológico. Así, el seguro obligatorio se derivada de las licencias ambientales, mientras que el voluntario tiene un carácter potestativo.

\subsubsection{Elementos esenciales del seguro ecológico}

El Estado tiene la obligación de realizar acciones positivas para facilitar, promover y proporcionar las medidas legislativas necesarias para la regulación del seguro ecológico, y también establecer los lineamientos administrativos de orden presupuestal y judicial que posibiliten a las personas y comunidades ejercitar el derecho al medio ambiente sano. Al mismo tiempo, le corresponde al Estado "[...] adoptar medidas para que se difunda información adecuada sobre la conservación del ambiente, su protección y los métodos para reducir la contaminación ambiental" (Corte Constitucional, Sent. C-851/10). Es evidente que el propósito del seguro ecológico no es la protección del medio ambiente, sino la salvaguarda del patrimonio de quien contamina y causa un daño. Seguro ecológico que tiene cuatro elementos esenciales: el interés asegurable, el riesgo asegurable, la prima y la obligación condicional del asegurador.

\subsubsection{El interés asegurable}

En el seguro ecológico, tiene interés asegurable el tomador o asegurado que, por ejemplo, deforesta y erosiona la tierra por la inadecuada explotación de los recursos naturales, es decir, quien genera un daño ambiental que puede ser demandado ante las autoridades, comprometiendo de esta manera su patrimonio. Este hecho debe generar conciencia sobre la importancia de la protección de la diversidad biológica, necesaria para la evolución y la preservación de la vida en la biosfera (onu, 1993). ${ }^{17} \mathrm{Al}$ no cuidar de la mencionada

\footnotetext{
17 "Los recursos biológicos de la Tierra son fundamentales para el desarrollo económico y social de la humanidad. Como consecuencia, existe un reconocimiento cada vez mayor de la diversidad biológica como bien mundial de valor inestimable para la supervivencia de las generaciones presentes y futuras. Al mismo tiempo la amenaza que pesa actualmente sobre las especies y los ecosistemas nunca ha sido tan grave. En efecto, la extinción de especies causada por las actividades del hombre continúa a un ritmo alarmante [...] En respuesta a ello, el Programa de las Naciones Unidas para el Medio Ambiente (PNUMA) convocó a un grupo especial de expertos sobre la diversidad biológica en noviembre de 1988, con el objeto de explorar la necesidad de un convenio internacional sobre la diversidad biológica. Poco tiempo después, en mayo de 1989, el PNUMA estableció el grupo de trabajo ad hoc de expertos jurídicos
} 
diversidad, se genera un cambio climático que lesiona los intereses de los seres que interactúan en el ecosistema.

Se entiende por cambio climático la serie de transformaciones producidas en el clima de la Tierra que impactan los ecosistemas, la vida en general y la humana en particular, lo que constituye un problema ambiental de gran relevancia en la actualidad, por "[...] la pérdida de la biodiversidad y el 'agujero’ de ozono. Los inconvenientes generados por el cambio climático están interrelacionados y ejercen sinergias entre ellos, se atribuye al aumento de la temperatura provocado por el ser humano la principal causa del cambio climático" (Tommasino y Foladori, 2006, p. 5).

\subsubsection{El riesgo asegurable}

Las empresas o personas naturales que en el ejercicio de su actividad puedan generar daño a una persona tienen interés asegurable, porque este seguro de daños reales y patrimoniales salvaguarda el patrimonio del potencial dañador ante la ocurrencia de un siniestro. Para efectos de la responsabilidad ambiental y el seguro ecológico, el riesgo es el hecho incierto que no depende de la voluntad del tomador o asegurado potencial generador de un daño ambiental, ni del beneficiario del seguro, es decir, la víctima a quien la aludida responsabilidad le genera perjuicios.

Además, la aplicación del régimen de responsabilidad objetivo con dimensión social incorporado en la responsabilidad ambiental se evidencia con la expedición de la Comprehensive Environmental Response Compensation and Liability Act o Cercla, donde se instituyen tres aspectos principales: la responsabilidad, la compensación a las víctimas de contaminación ambientaly la recuperación del ambiente de la zona afectada (Pinilla,2003,pp. 157-179). ${ }^{18}$ Esta norma crea un impuesto a cargo de la industria petrolera y de productos

y técnicos para preparar un instrumento jurídico internacional para la conservación y la utilización sostenible de la diversidad biológica. Los expertos debieron tomar en consideración 'la necesidad de compartir los costos y los beneficios entre los países desarrollados y los países en desarrollo', así como 'los medios y la modalidad para apoyar las innovaciones de las comunidades locales" (onu, 1993) (Cfr. http://www.cbd.int/history/default.shtml).

18 Anteriores a la Cercla, se promulgaron leyes que sectorialmente establecieron el sistema de responsabilidad objetiva, tales como la Clean Air Act en 1970, la Clean Water Act en 1977, la Resource Conservative and Recovery Act en 1976, que regula el tratamiento de los desechos sólidos y peligrosos (Pinilla, 2003, pp. 157-179). 
químicos, y otorga plenas facultades a la autoridades para contrarrestar las “[... ] amenazas de escape de sustancias peligrosas que podrían poner en peligro la salud pública o el ambiente"(Agencia de Autoridad Ambiental de los Estados Unidos, 1986)..$^{19}$

\subsubsection{La prima}

La prima en el seguro ecológico es el precio del seguro, que debe ser proporcional al riesgo trasladado por el tomador a la compañía aseguradora. La responsabilidad ambiental está ubicada en el régimen objetivo de responsabilidad, es decir, en la dimensión social del riesgo, razón por la cual el monto de la prima es considerablemente alto. Así mismo, empieza a incorporarse en el vocabulario de las personas la expresión "la era atómica", relacionada con las fuentes de energía que serán utilizadas en el futuro, y el nacimiento de las centrales nucleares, donde existen numerosos siniestros generadores de un daño (González, 2012, p. 299), ${ }^{20}$ denominados 'accidentes nucleares'; accidentes donde es aplicada la mencionada teoría del riesgo con dimensión social, con el propósito de salvaguardar los derechos de las víctimas de daños nucleares.

Por ende, el siniestro relacionado con un accidente nuclear es un hecho que origina daños que provienen de las propiedades radiactivas, tóxicas, explosivas o peligrosas originadas por "[...] combustibles nucleares o productos o desechos radiactivos, o de las radiaciones ionizantes emitidas por otra fuente cualquiera de radiaciones que se encuentre en una instalación nuclear"

${ }^{19}$ Recuperado de http://www.epa.gov/superfund/spanish/descripcion_cercla.htm. La Cercla “[...] establece prohibiciones y requisitos para sitios con desperdicios peligrosos que están cerrados y abandonados; [...] provee responsabilidad a las personas responsables de emitir los desperdicios peligrosos en estos sitios; y [...] estableció un fondo de fideicomiso para proveer limpieza, mejora o restauración cuando el grupo o la persona potencialmente responsable no puede ser identificado".

20 "Se han producido dos accidentes con consecuencias radiológicas importantes en centrales nucleares, el de Chernobyl y el de Fukushima Daiichi, además de un accidente sin consecuencias radiológicas, el de la central de Three Mile Islands. Todos estos accidentes han recibido amplia publicidad. Sin embargo, ha pasado casi inadvertido que han tenido lugar más de 100 accidentes con fuentes industriales y médicas, especialmente con las denominadas fuentes 'huérfanas' (es decir, no sujetas a los controles reglamentarios), que han ocasionado lesiones a trabajadores y a la población. También han ocurrido accidentes durante los usos médicos de las radiaciones, casi siempre por error humano o mecánico durante la radioterapia. Aunque se sabe que los accidentes relacionados con fuentes huérfanas y los usos médicos de las radiaciones se han vuelto más frecuentes, es probable que las cifras actuales de las estimaciones reflejen niveles inferiores, o posiblemente muy inferiores, a los reales, debido a que los datos son incompletos"(González, 2012, p. 299). 
(Convención Internacional de París, 1960). En la responsabilidad causada al medio ambiente, se presume la responsabilidad del tomador o asegurado y, por esta razón, el valor de la prima, elemento esencial del seguro ecológico, es considerablemente elevado, porque los eximentes de responsabilidad a favor del victimario asegurado son limitados.

\subsubsection{La obligación condicional del asegurador}

La obligación del asegurador es un elemento esencial del seguro, sumado al interés asegurable, la prima y el riesgo asegurable. Es relevante indicar que el seguro ecológico está regulado por normas de carácter mercantil, lo que indica que el asegurador está obligado a pagar el siniestro, de acuerdo con lo establecido en el contrato. De esta manera, para determinar el daño ecológico generado por una persona natural o empresa, "la respectiva autoridad ambiental previa solicitud del interesado podrá certificar sobre la ocurrencia y la cuantía del siniestro, mediante acto administrativo debidamente motivado. El dictamen podrá servir de fundamento para la reclamación ante el asegurador, o en el proceso judicial que eventualmente se adelante" (Congreso de la República de Colombia, Código Penal, 1999, art. 6º. Por ende, el documento que certifique lo señalado con anterioridad es una prueba documental declarativa importante en el proceso extrajudicial o judicial en contra de la compañía de seguros; empresa que paga el siniestro conforme con las condiciones establecidas en la póliza.

Algunas compañías son renuentes a cubrir los riesgos desconocidos o con índices de siniestralidad existentes,y, por esta razón, imponen primas con valor significativo. En suma, las “[...] primas en materia de seguros de responsabilidad ambiental suelen aumentar sustancialmente debido al grado superior de incertidumbre que existe" (Jaquenod de Zsögön, 2004, p. 397).21 Adicionalmente,

\footnotetext{
${ }^{21}$ En materia de responsabilidad civil e indemnización por daños al ambiente, existen importantes documentos, tales como el "Convenio de París (1960) sobre responsabilidad civil en el campo de la energía nuclear, Convenio de Bruselas (1963) por el que se establece un sistema complementario de indemnización por los daños causados por incidentes nucleares, Convenio de Viena (1963) sobre responsabilidad civil por daños nucleares, Convenio Internacional de Bruselas (1969) sobre responsabilidad civil por daños causados por la contaminación de las aguas del mar por hidrocarburos, Convenio de Bruselas (1971) sobre constitución de un fondo internacional de indemnización de daños causados por la contaminación de hidrocarburos, Convenio de Londres (1977) sobre responsabilidad civil por los daños de contaminación por hidrocarburos resultantes de la exploración y explotación de los recursos minerales de los fondos marinos, Convenio de Bruselas (1971) relativo a la responsabilidad civil en la esfera del transporte marítimo de materiales nucleares, Convenio de Ginebra (1989) sobre
} 
se indica en la norma que la prescripción extintiva o liberatoria derivada del contrato de seguro es de dos años, establecidos de la siguiente manera: la prescripción ordinaria es de dos años y la extraordinaria de cinco años (Congreso de la República de Colombia, Código Penal,1999, art.99).22 La compañía aseguradora no se obliga a pagar la indemnización establecida en la póliza en el evento de operar la prescripción derivada de daños patrimoniales por responsabilidad civil. Es decir, la 'objeción' de pago del siniestro opera porque se extinguió la obligación por el transcurso del tiempo.

La víctima del hecho dañoso en materia ambiental cuenta con cinco años para ejercer su derecho a demandar en acción directa al asegurador, y, de no hacerlo, pierde la oportunidad de legitimar por activa a la compañía de seguros, y demandarla en un solo proceso. En concreto, la norma señala que "en el seguro de responsabilidad civil los damnificados tienen acción directa contra el asegurador. Para acreditar su derecho ante el asegurador de acuerdo con el artículo 1077, la víctima en ejercicio de la acción directa podrá en un solo proceso, demostrar la responsabilidad del asegurado y demandar la indemnización del asegurador" (Código de Comercio, art. 1133).

\subsection{Intervinientes en el seguro ecológico}

En el seguro ecológico, intervienen diferentes actores en calidad de partes, intermediarios, reaseguradores, ajustadores de seguros, actuarios, así como el beneficiario, quien es la víctima directa o indirecta del perjuicio generado.

\subsubsection{Las partes}

Son partes del seguro ecológico el tomador o asegurado y el asegurador, quien es persona jurídica, sociedad anónima, con un objeto social exclusivo y excluyente, es decir, producir seguros y comercializarlos de forma directa por medio de los intermediarios de seguros. Se aclara que el beneficiario del seguro ecológico obligatorio es interviniente y no parte en la póliza.

responsabilidad civil por daños causados durante el transporte de mercancías peligrosas por carretera, ferrocarril y buques de navegación interior” (Jaquenod de Zsögön, 2004, p. 397).

${ }^{22}$ La norma establece que "los términos de prescripción para las acciones que se derivan del contrato de seguro, contenidos en los artículos 1081 y 1131 del Código de Comercio o las normas que lo sustituyan o lo modifiquen, se hacen extensivas a los seguros ecológicos y se contarán desde el momento en que se tenga conocimiento del daño durante la vigencia de la respectiva póliza" (Congreso de la República de Colombia, Código Penal, 1999, art. 9o). 


\subsubsection{El tomador $\mathrm{o}$ asegurado}

El deterioro ambiental generado por el tomador o asegurado de la póliza es un hecho recurrente en Colombia. Nación con uno de los mayores índices de biodiversidad, y, a su vez, con un alto grado de detrimento ambiental producido por la extracción de minerales preciosos; extracción de oro, por ejemplo, donde son utilizados tóxicos que producen daño al suelo y a las fuentes hídricas aledañas a la explotación de los recursos naturales (Рві Colombia, 2011, p. 6). Es factible que la empresa o persona que realiza la actividad minera haya suscrito un seguro ecológico a través del cual la compañía de seguros cancela los perjuicios generados a la víctima en la actividad minera.

No obstante, si el valor amparado o límite de indemnización establecido entre el asegurador y el tomador no cubre la cuantía de los perjuicios producidos por el daño, "[...] quien fuere causante del hecho deberá responder por el monto de todos los daños y perjuicios que se hubieren producido en exceso de las sumas aseguradas en la póliza" (Congreso de la República de Colombia, Código Penal, 1999, art. 90). Es evidente que las Naciones Unidas y lo consagrado por los principios del derecho internacional señalan que todos los Estados tienen el derecho de explotar y aprovechar sus recursos; sin embargo, si en los referidos procesos se generan daños por no acatar las políticas ambientales existentes en cada país, la compañía de seguros o el victimario tienen que garantizar el derecho humano y fundamental a la reparación integral a las víctimas.

Se insiste en que el Estado tiene el derecho a la exploración de los recursos naturales, pero tiene a su vez la obligación de inspeccionar, vigilar y controlar que las actividades desarrolladas dentro del país no causen daño al medio ambiente interno o externo, es decir, al de otro Estado vecino (Geary, 2006, p. 10). ${ }^{23}$ En el evento de exteriorizarse el riesgo asegurado, es decir,

\footnotetext{
${ }^{23} \mathrm{El}$ conflicto entre Argentina y Uruguay es un ejemplo de contaminación ambiental que traspasa la jurisdicción local. "El caso de las plantas de celulosa sobre la margen izquierda del río Uruguay podría ser leído como un conflicto diplomático, donde los reclamos entre los gobiernos de Argentina y Uruguay se deben a diferencias producidas en relación al uso del río como un bien público compartido. Sin embargo, a partir del conflicto trasciende que es un problema antiguo mucho más complejo, atravesado por cuestiones ambientales, que lleva más de tres años, donde gobiernos, vecinos organizados, grupos de estudiosos, técnicos y expertos vienen discutiendo y construyendo estrategias con resultados aún inciertos. El núcleo de la discusión radica en identificar, definir y argumentar la viabilidad ambiental y el riesgo del emprendimiento. Es decir, si el proyecto - ya avanzado, y cuya magnitud debe enfatizarse - pone en riesgo la salud y las actividades productivas de la población" (Geary, 2006, p. 10).
} 
causar daño al Estado o a terceros víctimas del hecho contaminante, “[...] el asegurado deberá dar aviso inmediato, por escrito, a la autoridad ambiental respectiva y al asegurador sobre el acaecimiento del daño" (Congreso de la República de Colombia, Código Penal, 1999, art. 9º). Al incumplirse con el reporte del daño antes indicado, la autoridad ambiental impondrá las multas establecidas por la norma (Congreso de la República de Colombia, Código Penal, 1999, art. 9o)..$^{24}$

\subsubsection{El asegurador}

El asegurador es la persona jurídica que 'produce' el seguro ecológico y lo comercializa de manera directa, o a través de los intermediarios de seguros. El Estado colombiano tiene a cargo las funciones de inspección, vigilancia y control de las compañías de seguros, por medio de la Superintendencia Financiera de Colombia; Estado que direcciona la economía nacional y regula los productos y servicios públicos ofrecidos, con el objetivo de mejorar la calidad de vida y la preservación del medio ambiente, que está en continuo riesgo de ser dañado (Constitución Política, 2013, art. 334). ${ }^{25}$ El riesgo de contaminación ambiental es catalogado como un hecho incierto que puede ser trasladado a una compañía aseguradora que tiene un objeto social exclusivo y excluyente, es

${ }^{24}$ La norma señala lo siguiente: "Quien estando obligado a reportar el daño y no lo hiciere oportunamente será multado por la respectiva autoridad ambiental hasta por el equivalente a cien (100) salarios mínimos mensuales legales vigentes, o a quinientos (500) salarios mínimos mensuales legales vigentes, si la circunstancia del reporte o su tardanza hubiere hecho más gravosas las consecuencias del daño" (Congreso de la República de Colombia, Código Penal, 1999, art. 9o).

${ }^{25}$ Es relevante, en esta parte del texto, hacer alusión al Estado social de derecho. En este sentido, “[...] el principio del ESDD impone la protección de los derechos constitucionales desde una perspectiva fáctica, esto es, comprometida con la satisfacción de los intereses de los grupos sociales menos favorecidos, a través de una relación de dependencia entre la ciudadanía plena y el acceso efectivo a las garantías y libertades. En ese orden de ideas, son indiscutibles las fórmulas de intervención del Estado en la economía que, sujetadas en todo caso a criterios de razonabilidad y proporcionalidad, tengan por objeto lograr la igualdad de oportunidades y la distribución equitativa de los beneficios del desarrollo. No de otra manera debe interpretarse el artículo 334 c.P., cuando prescribe que esa intervención se justifica en cuanto tiene como finalidad la racionalización de la economía con el fin de conseguir el mejoramiento de la calidad de vida de los habitantes, la mencionada distribución equitativa y la preservación de un ambiente sano. Incluso, la misma fórmula constitucional de intervención del Estado en la economía reafirma el carácter nodal de la igualdad material, cuando determina que esa tarea se realizará con mayor énfasis cuando se trate de dar pleno empleo a los recursos humanos y asegurar que todas las personas, en especial las de menores ingresos, tengan acceso efectivo a los bienes y servicios básicos" (Corte Constitucional, Sent. C-288/12). 
decir, su única actividad mercantil es la de producir seguros y comercializarlos de manera directa o a través del agente, la agencia o el corredor de seguros. La compañía aseguradora es la acreedora de una prima o costo del seguro, que está a cargo del tomador o asegurado, quien tiene la obligación positiva de dar, esto es, pagar el valor respectivo por el traslado del riesgo.

\subsubsection{El beneficiario del seguro}

Las víctimas del daño ambiental tienen tres derechos fundamentales que deben ser protegidos por el Estado: el derecho a la verdad, a la justicia y a la reparación integral. El legislador ha señalado unos elementos que configuran el concepto de reparación integral, y no únicamente la indemnización pecuniaria a cargo del responsable del daño ambiental, “[... ] sino cualesquiera otras expresiones que contengan la verdad y la justicia, así como las actuaciones que de modo razonable reclame la víctima" (Corte Constitucional, Sent. C-409/09, p.5).Para garantizar los mencionados derechos, se puede ejercer la denominada 'acción directa de la víctima del daño ambiental' en contra del asegurador, es decir, las víctimas del daño producido en una explotación minera pueden demandar judicialmente en un mismo proceso al productor directo del daño, así como también al asegurador de la persona natural o jurídica causante de este (Código de Comercio, art. 1033). ${ }^{26}$

Lo anterior de acuerdo con las tendencias evolutivas de la responsabilidad civil, que promueven el derecho a la reparación integral de las víctimas; no obstante, "[...] la finalidad del seguro no puede confundirse con la de la preservación del ecosistema, porque su deterioro no lo previene el seguro" (Zornosa,2000). Los beneficiarios del seguro ecológico son las personas naturales o jurídicas afectadas por el daño generador de perjuicios patrimoniales y extrapatrimoniales; los primeros, divididos en daño emergente y lucro cesante, y los segundos, los perjuicios extrapatrimoniales o inmateriales, clasificados en morales, perjuicios a la salud y la pérdida de la oportunidad. La víctima, quien es beneficiaria de la póliza, puede ser directa o indirecta, porque los causahabientes o familiares de la víctima directa también tienen la categoría

\footnotetext{
${ }^{26}$ La norma comercial indica lo siguiente: "En el seguro de responsabilidad civil los damnificados tienen acción directa contra el asegurador. Para acreditar su derecho ante el asegurador de acuerdo con al artículo 1077, la víctima en ejercicio de la acción directa podrá en un solo proceso demostrar la responsabilidad del asegurado y demandar la indemnización del asegurador" (Código de Comercio, art.1033).
} 
de beneficiarios del seguro. A su vez, el Estado es también beneficiario de la indemnización y, en ese caso concreto, "[...] el monto de la indemnización deberá destinarse a la reparación, reposición o restauración de los recursos naturales o ecosistemas deteriorados"(Congreso de la República de Colombia, Ley 23 de 1973, art. 5o).

En suma, se instituye en una obligación de la empresa o de la persona natural abstenerse de causar un daño en la actividad que corresponda a la explotación minera, por ejemplo, en el territorio nacional o fuera de él; es decir, se debe evitar la ocurrencia del siniestro irreparable de naturaleza ambiental que perjudique al Estado colombiano o a la nación vecina. Así mismo, "cuando las actividades de reparación, reposición o restauración no sea posible realizarlas, el monto de la indemnización será invertido directamente en proyectos ecológicos o ambientales de especial interés para la comunidad afectada" (Congreso de la República de Colombia, Ley 23 de 1973, art. 5º).

\subsubsection{Los intermediarios del seguro ecológico}

Los intermediarios de seguros son personas naturales o jurídicas cuya actividad está centrada de manera exclusiva y excluyente a la comercialización de un producto: el seguro; en este caso, el seguro ecológico que cubre los daños causados a terceros y los generados al tomador o asegurado. Los intermediarios que comercializan el seguro ecológico son tres: en primer lugar, se encuentra el agente de seguros, quien es una persona natural con categoría de comerciante, que tiene los conocimientos técnicos para asesorar al potencial causante de daños ambientales; en segundo lugar, el agente de seguros, persona jurídica constituida como sociedad de responsabilidad limitada o colectiva; $y$, por último, el corredor de seguros o el denominado insurance broker. El nombrado corredor es una

persona física o jurídica que realiza la actividad mercantil de mediación de seguros privados sin mantener vínculos contractuales que supongan afección con entidades aseguradoras, y que ofrece asesoramiento independiente, profesional e imparcial a quienes demanden la cobertura de los riesgos a que se encuentran expuestos sus personas, sus patrimonios, sus intereses o responsabilidades [...] Los corredores de seguros deberán informar a quien trate de concertar el seguro sobre las condiciones del contrato que a su juicio conviene suscribir 
y ofrecer la cobertura que, de acuerdo a su criterio profesional, mejor se adapte a las necesidades de aquel; asimismo, velarán por la concurrencia de los requisitos que ha de reunir la póliza de seguro para su eficacia y plenitud de efectos (Mapfre, 2014). ${ }^{27}$

A continuación, se hace referencia a los reaseguradores, en su calidad de intervinientes en el contrato de seguro ecológico, mas no intermediarios de este.

\subsubsection{El reasegurador}

En términos sencillos, se puede afirmar que el reasegurador es la persona jurídica que asegura el patrimonio del asegurador, quien le cede de forma total o parcial el riesgo trasladado por el tomador o asegurado. Por ejemplo, la compañía minera, en calidad de tomadora en el seguro ecológico, le traslada el riesgo a la compañía aseguradora a cambio del pago de una prima, y, a su vez, dicha compañía de seguros descarga el riesgo trasladado por el tomador a la reaseguradora. Por medio del contrato de reaseguro, el asegurador protege su patrimonio, que puede ser afectado como consecuencia de la ocurrencia del siniestro, es decir, del daño ambiental generador de perjuicios.

El Estado, a través del Ministerio de Ambiente, Vivienda y Desarrollo Territorial, ha resaltado la importancia de contar con un adecuado reaseguro, y, a su vez, establecer apropiadas coberturas y valores asegurables proporcionales al riesgo trasladado. No es suficiente que se contrate un seguro ecológico por parte del tomador o asegurado, y que el asegurador al mismo tiempo descargue el riesgo

27 "Igualmente, vendrán obligados durante la vigencia del contrato de seguro en que hayan intervenido a facilitar al tomador, al asegurado y al beneficiario del seguro la información que reclamen sobre cualquiera de las cláusulas de la póliza y, en caso de siniestro, a prestarles su asistencia y asesoramiento [...] El pago del importe de la prima efectuado por el tomador del seguro al corredor no se entenderá realizado a la entidad aseguradora, salvo que, a cambio, el corredor entregue al tomador del seguro el recibo de prima de la entidad aseguradora [...] Para ejercer la actividad de corredor de seguros, será precisa la previa inscripción en el Registro Administrativo Especial de Mediadores de Seguros, Corredores de Reaseguros y de sus Altos Cargos"(Mapfre, 2014).

"Las relaciones con las entidades aseguradoras derivadas de la actividad de mediación del corredor de seguros se regirán por los pactos que las partes acuerden libremente, sin que dichos pactos puedan en ningún caso afectar a la independencia del corredor de seguros [...] Las relaciones de mediación de seguros entre los corredores de seguros y su clientela se regirán por los pactos que las partes acuerden libremente y supletoriamente por los preceptos que el Código de Comercio dedica a la comisión mercantil [...] La retribución que perciba el corredor de seguros de la entidad aseguradora por su actividad de mediación de seguros revestirá la forma de comisiones” (Mapfre, 2014). 
a un asegurador,lo imprescindible es suscribir la póliza con coberturas adecuadas, con exclusiones mínimas y con valores asegurados y límites de indemnización proporcionales al riesgo trasladado, por la persona natural o jurídica potencial generadora del daño ambiental. Así mismo, es relevante hacer uso de sistemas de ocurrencia y reclamación del siniestro, al que se hace referencia a continuación.

\subsubsection{El sistema 'claims made' en el seguro ecológico}

Al momento de la suscripción de la póliza de responsabilidad civil, comienza a ser recurrente la cobertura de riesgos generados en la empresa, incluyendo los riesgos ambientales inherentes al desarrollo del objeto social de las compañías. La póliza denominada Comprehensive General Liability (CGL) es un ejemplo de amparo destinado al pago de los perjuicios derivados de la responsabilidad civil en que incurran las empresas, y está "[...] destinada a la cobertura de la contaminación directamente accidental, contaminación que resulta de un hecho eventual y fortuito"(Pinilla, 2003, pp.157-179). En la citada póliza CGL, la contaminación es definida como un daño al medio ambiente, el cual es factible identificar de manera concreta en el momento de la ocurrencia del siniestro, con el agravante de no permitir el aseguramiento de las consecuencias que se puedan generar a largo plazo. Por ende, este seguro únicamente tiene un cubrimiento de daños concretos y presentes, y, “[...] en cuanto a la delimitación temporal, el período de garantía es del tipo occurrence y cubre los siniestros sobrevenidos dentro del período de garantía" (Malaval, 1999, pp. 30-31).

Sin embargo, el daño ecológico generado por la empresa o persona natural tomadora o asegurada de la póliza puede exteriorizarse con posterioridad al hecho medioambiental culposo o doloso; es decir, el hecho contaminante ocurre en un tiempo determinado, pero los perjuicios se presentan con posterioridad, por ejemplo, después de dos o más años. Por esta razón, se incorpora por parte de las empresas aseguradoras el sistema claims made, que permite al asegurador nacional e internacional incrementar de forma importante su capacidad de reacción cuando se presenten eventos dañosos que se exterioricen en el futuro.

El hecho generador del daño ecológico puede manifestarse en el mismo momento de la ocurrencia del hecho; no obstante, el daño o la demanda de indemnización de este en contra del agente contaminador asegurado puede presentarse con posterioridad. Por esa razón, el sistema claims se instituye para 
manejar de manera eficiente este inconveniente, donde pueden suceder siniestros tardíos o latentes (Comerio, 2010, pp. 30-31).

\section{Conclusiones}

En la investigación realizada, se encontró que el Estado colombiano busca, a través de normas, reglas y principios, la protección de los recursos naturales de la nación; normas de carácter constitucional y legal, expedidas para proteger el medio ambiente en todos los contextos. Se identificó que el citado medio ambiente es catalogado como un derecho humano, que trata de ser salvaguardado por la comunidad internacional. No obstante, uno de los hallazgos más significativos fue el hecho de comprobar que, al ponderar los derechos al medio ambiente sano con la explotación de los recursos naturales, este último prevalece sobre el primero, situación que se considera reprochable.

A su vez, se descubrió que el Estado expidió una norma especial que regula el seguro ecológico, y lo clasifica en obligatorio y voluntario. Al hacer el estudio acerca del citado seguro, se identificó que el propósito de la celebración del contrato es la protección del patrimonio del potencial causante de daños sobre el medio ambiente, y, a su vez, garantizar el derecho fundamental a la indemnización integral a las víctimas de este. Sin embargo, se concluyó que la norma no incorpora disposiciones que tengan la intención de identificar, prevenir y amparar al medio ambiente.

\section{Bibliografía}

Adzel Riba, J. (1987). Cómo se trabaja la piel. Barcelona: Editorial De Vecchi.

Asociación de Aseguradores de Chile A.G. Cobertura de responsabilidad civil por contaminación, adicional a: póliza de responsabilidad civil POL 197008.

Asociación de Aseguradores de Chile A.G. Póliza de responsabilidad civil. CAD 197009. Res. 211 del 17/07/1997.

Asthon, T. S. (1989). La Revolución Industrial. México: Fondo de Cultura Económica.

Chavarro,J. (2010). Licencias y protección de los recursos naturales. Bogotá: Editorial Nueva Legislación.

Cherni,J. (2006). Reseña de Worlds apart. Globalization and the environment de James Gustave Speth (ed.). Buenos Aires: Red Theomai.

Colombia, Congreso de la República. (2013). Constitución Politica de Colombia. Bogotá, D.C.: Editorial Legis. 
Colombia, Congreso de la República. Código Penal, 1999.

Colombia, Congreso de la República. Decreto 2811 de 1974. Por el cual se dicta el Código Nacional de Recursos Naturales Renovables y de Protección al Medio Ambiente.

Colombia, Congreso de la República. Ley 23 de 1973. Por la cual se conceden facultades extraordinarias al Presidente de la República para expedir el Código de Recursos Naturales y de Protección al Medio Ambiente y se dictan otras disposiciones.

Colombia, Corte Constitucional. Expediente D-8422 del 31 de agosto de 2011. M. P.: Jorge Iván Palacio.

Colombia, Corte Constitucional. Sentencia C-288 de 2012. Expediente D-8690. M. P.: Luis Ernesto Vargas Silva.

Colombia, Corte Constitucional. Sentencia C-339 de 2002. M. P.: Marco Gerardo Monroy Cabra.

Colombia, Corte Constitucional. Sentencia C-409 de 2009. M. P.: Juan Carlos Henao Pérez.

Colombia, Corte Constitucional. Sentencia C-443 de 2009. M. P.: Nilson Elías Pinilla Pinilla.

Colombia, Corte Constitucional. Sentencia C-651 de 2003. M. P.: Jaime Araújo Rentería.

Colombia, Corte Constitucional. Sentencia T-419 de 1992. M. P.: Simón Rodríguez Rodríguez.

Colombia, Corte Constitucional. Sentencia T-851 de 2010. M. P.: Humberto Antonio Sierra Porto.

Comerio, J. J. (2010). Coloquio Seguros \& Justicia; cobertura en base claims made. Desafios, necesidad, funcionamiento. Miami: General RE.

Díaz Carela, D., \& Méndez, F. C. (2011). Hacia una ética de la biosfera para la crisis ambiental. Madrid: Universidad Complutense de Madrid.

Esguerra Portocarrero, J. C. (2004). La protección constitucional del ciudadano. Bogotá: Legis Editores S.A.

Galvis Segura, S. (marzo, 1999). El seguro de contaminación en el mercado internacional de reaseguros. Ponencia presentada en el Foro sobre Seguro Ecológico, Especialización de Derecho del Medio Ambiente y Centro de Estudios de Derecho de Seguros, Universidad Externado de Colombia, Bogotá.

Gamboa Berna, G. A (2011). "La Tierra: un planeta posible para siete mil millones y más”. Persona y Bioética, 15(2), 101-106. 
Geary, M. (2006). "El conflicto de las papeleras". Revista Otro Sur, 5.

Ghersi, C. (1995). Modernos conceptos de responsabilidad civil. Medellín: Biblioteca Jurídica Diké.

González, A. (2012). La seguridad nuclear: escenarios posibles tras Fukushima. Argentina: Academia Nacional de Ingeniería (ANI).

Jankilevich, S. (2003). Las cumbres mundiales sobre el ambiente. Estocolmo, Rio y Johannesburgo. 30 años de historia ambiental. Argentina: Universidad de Belgrano.

Jaquenod de Zsögön, S. (2004). Derecho ambiental. Madrid: Dykinson.

Malaval, F. (1999). Développement durable, assurances et environnement. París: Ed. Económica.

Mapfre. (2014). Diccionario Mafpre de seguros. Madrid: Fundación Mapfre. Recuperado de http://www.mapfre.com/wdiccionario/terminos

Medina Pabón,J. (2009). “Hacia una nueva teoría de la responsabilidad”. Revista Estudios Socio-Jurídicos, 7(1), 165. Bogotá: Universidad del Rosario.

Narváez Bonnet, J. (2000). "De la responsabilidad civil por el daño ambiental y el seguro ecológico en Colombia”. Revista Ibero-Latinoamericana de Seguros, 15.

Nique, M. (2010). “Biodiversidad: clasificación y cuantificación”. Tingo María, Perú: Universidad Nacional Agraria de la Selva.

рві Colombia. (2011). Minería en Colombia: ¿̨a qué precio? Bogotá: Pв I.

Pinilla Rodríguez, F.(2003). “Algunas consideraciones en torno al seguro ambiental: panorama comparado y situación dentro del sistema de evaluación de impacto ambiental vigente en Chile". Rev. Derecho (Valdivia), 15, 157-179.

Rodríguez R., Narran, F., \&Alonso, B. (1997). Mecanismos jurídicos de la protección ambiental. Bogotá: Ediciones Jurídicas Gustavo Ibáñez.

Sáchica, L. C., \& Vidal Perdomo, J. (1991). La constituyente de 1991. Bogotá: Cámara de Comercio.

Salazar Vargas, C. (2009). La definición de política pública. Ciudad de México: Fundación Preciado.

Tommasino, H., \& Foladori, G. (2006). Certezas sobre la crisis ambiental. Buenos Aires: Red Theomai.

Velásquez Gavilanes, R. (2009)."Hacia una nueva definición del concepto 'política pública". Revista Desafios, 20, 149-187. Bogotá: Universidad del Rosario.

Zornosa Prieto, H. (2000). “Comentarios a la Ley colombiana No 491 del seguro ecológico expedida el 13 de enero de 1999. En AA.vv., Lecturas sobre derecho del medio ambiente. T. 1". Bogotá: Universidad Externado de Colombia. 
Este libro fue compuesto en caracteres Adobe Caslon Pro

11,5 puntos, impreso sobre papel propal de 70 gramos y encuadernado con método hot melt, en septiembre de 2015, en Bogotá, D. C., Colombia. 